UNIVERSIDADE DE SÃO PAULO

FACULDADE DE ECONOMIA, ADMINISTRAÇÃO E CONTABILIDADE DEPARTAMENTO DE ECONOMIA PROGRAMA DE PÓS-GRADUAÇÃO EM ECONOMIA

OS DETERMINANTES DA QUALIDADE DA EDUCAÇÃO NO BRASIL

Ana Maria de Paiva Franco

Orientador: Prof. Dr. Naercio Aquino Menezes-Filho

SÃO PAULO 
Profa. Dra. Suely Vilela

Reitora da Universidade de São Paulo

Prof. Dr. Carlos Roberto Azzoni

Diretor da Faculdade de Economia, Administração e Contabilidade

Prof. Joaquim José Martins Guilhoto

Chefe do Departamento de Economia

Prof. Dante Mendes Aldrighi

Coordenador do Programa de Pós-Graduação em Economia 


\section{OS DETERMINANTES DA QUALIDADE DA EDUCAÇÃO NO BRASIL}

Tese apresentada ao Departamento de Economia da Faculdade de Economia, Administração e Contabilidade da Universidade de São Paulo como requisito para a obtenção do título de Doutor em Economia

Orientador: Prof. Dr. Naercio Aquino Menezes-Filho 
Tese defendida e aprovada no Departamento de Economia da Faculdade de Economia, Administração e Contabilidade da Universidade de São Paulo - Programa de Pós-Graduação em Economia, pela seguinte banca examinadora:

\section{FICHA CATALOGRÁFICA}

Elaborada pela Seção de Processamento Técnico do SBD/FEA/USP

Franco, Ana Maria de Paiva

Os determinantes da qualidade da educação no Brasil /

Ana Maria de Paiva Franco. - São Paulo, 2008.

$149 \mathrm{p}$.

Tese (Doutorado) - Universidade de São Paulo, 2009

Bibliografia

1. Educação - Aspectos econômicos 2. Qualidade da educação 3. Econometria 4. Avaliação da educação I. Universidade de São Paulo. Faculdade de Economia, Administração e Contabilidade II. Título,

$$
\text { CDD }-370
$$


A meus pais, Antônio e Cida por tudo. 
Em primeiro lugar gostaria de agradecer a toda minha família: pais, irmãos, sobrinha, tios e primos queridos, que acompanham e participam desde sempre de minhas empreitadas acadêmicas! Eles formam uma torcida animada e confiante, e sempre pronta a ajudar em qualquer situação. São minha base, minhas raízes, e minha fonte de inspiração.

Gostaria de agradecer especialmente a meu orientador Naercio Aquino MenezesFilho, pelo apoio e ensinamentos transmitidos durante todas as etapas deste trabalho. Foi uma grande experiência poder trabalhar com ele e aprender um pouco do muito conhecimento que possui e que sabe, como poucos, transmitir. A idéia inicial do trabalho era a de tentar captar o "efeito do professor" sobre o aprendizado dos alunos. Este “efeito professor" é determinante para a transmissão de conhecimento, e ao mesmo tempo muito específico e de difícil mensuração. Um bom professor é aquele que consegue transmitir seu entusiasmo, sua curiosidade e paixão pelo conhecimento a seus alunos, e é exatamente isto o que faz do Professor Naercio um dos melhores professores que já tive.

Faço um agradecimento também especial ao Professor Marco Manacorda, do Departamento de Economia da Queen Mary University of London, pela sua receptividade e estímulo ao aperfeiçoamento deste trabalho durante os oito meses de meu doutorado sanduíche naquela Universidade. Foi uma honra poder conhecê-lo e contar com sua simpatia e disposição em alargar meu campo de visão sobre a microeconometria e sua aplicação no campo do desenvolvimento econômico.

Agradeço o incentivo e apoio constantes da grande amiga Elaine. Agradeço também a Roberta Loboda e Lídia Ferraz do INEP, pela ajuda prestada com relação aos dados do Censo Escolar e SAEB, e ao INEP pela concessão dos dados.

Agradeço toda a atenção e ajuda das prestativas secretárias da Pós-Graduação da FEA, em especial à Márcia Bento, Valéria Lourenção e Camila Barros, e também agradeço ao pessoal da biblioteca, em especial a Gisele Oliveira. Por fim, agradeço ao Conselho Nacional de Pesquisa e Desenvolvimento (CNPq) pelo apoio financeiro durante todo o período de elaboração desta tese. 


\section{RESUMO}

As questões por trás da qualidade no ensino são centrais na área da economia da educação e de particular interesse para os países em desenvolvimento como o Brasil. Este trabalho analisa os impactos de diferentes características dos alunos, professores, turmas, diretores e escolas no desempenho dos alunos da $4^{\mathrm{a}}$ série em Matemática, utilizando-se dois conjuntos de painéis de escolas construídos com base no SAEB de 1997, 1999, 2001, 2003 e 2005. Por utilizar uma base de dados pouco explorada para estas questões no caso do brasileiro, conseguiu-se captar o efeito de importantes variáveis que influenciam o aprendizado. Além disso, diferentes medidas utilizadas para se construir rankings de escolas foram analisadas utilizando-se os dados do SAEB. Os resultados indicam que há uma série de dificuldades envolvidas na construção de rankings confiáveis para guiarem as decisões dos agentes com base em exames de avaliação educacional, devido à elevada estratificação no sistema educacional e ao problema de reversão para a média, que causam ruído nas estimativas. Disto resulta que na maioria dos casos existe um "trade-off" entre o ranking refletir, principalmente, o SSE dos alunos da escola, por um lado, e apresentar uma volatilidade, por outro. No quarto capítulo avalia-se o impacto do FUNDEF sobre uma série de indicadores educacionais ao longo dos anos 1999, 2001, 2003 e 2005. Para tal utiliza-se um painel de 2.837 municípios com informações sobre suas escolas particulares e municipais, tiradas do Censo Escolar, e sobre os recursos líquidos recebido do Fundo, informações estas contidas na base FINBRA do Ministério da Fazenda. As estimações do "efeito-Fundef” são feitas pelo método de diferenças em diferenças simples e através do ajuste de quatro modelos de Efeitos Fixos. Os resultados apontam que o FUNDEF promoveu um aumento de da maior parte dos insumos escolares considerados, e há indícios de que tenha melhorado a qualidade do ensino quando são analisados os indicadores de fluxo e rendimento escolar. 


\begin{abstract}
The questions behind the quality in education are central in the field of economics of education and of particular interest for developing countries like Brazil. This work analyses the impacts of different characteristics of the students, teachers, classes, headmasters and schools on $4^{\text {th }}$ grade student's outcomes in mathematics with the use of two panel data sets built from the five SAEB's cycles 1997, 1999, 2001, 2003 and 2005. Because it uses a data base yet not very explored for these questions in the Brazilian case, it was possible to capture the effects of important variables that influence achievement. Furthermore, different measures used to construct school rankings were analyzed using SAEB's data. The results point that it is hard to construct trustful school's rankings to guide agent's decisions based on educational evaluation exams because of the high stratification in the educational system and the mean reversion problem, that cause noise on the estimates. This implies that in most cases there is a trade-off between the rankings reflecting mainly the SES of the students, for one side, and present volatility, on the other. In the $4^{\text {th }}$ chapter the impacts of FUNDEF over many educational indicators are evaluated thru the years 1999, 2001, 2003 and 2005. For that purpose a panel of 2.837 municipalities with information on theirs municipal and private schools and the net revenue they received from FUNDEF is used. School's characteristics were obtained from the "Censo Escolar", and the net transfers from FUNDEF to each municipality were obtained on the Ministry of Finances' data base named FINBRA. The "Fundef-effect" estimations are made with the simple difference-in-difference methodology and through the adjustment of four Fixed Effects models. The results points that FUNDEF had promoted an improvement on the school's inputs indicators and one can also infer that there has been an improvement on the quality of education when its effects on promotion and abandon rates are analyzed.
\end{abstract}




\section{SUMÁRIO}

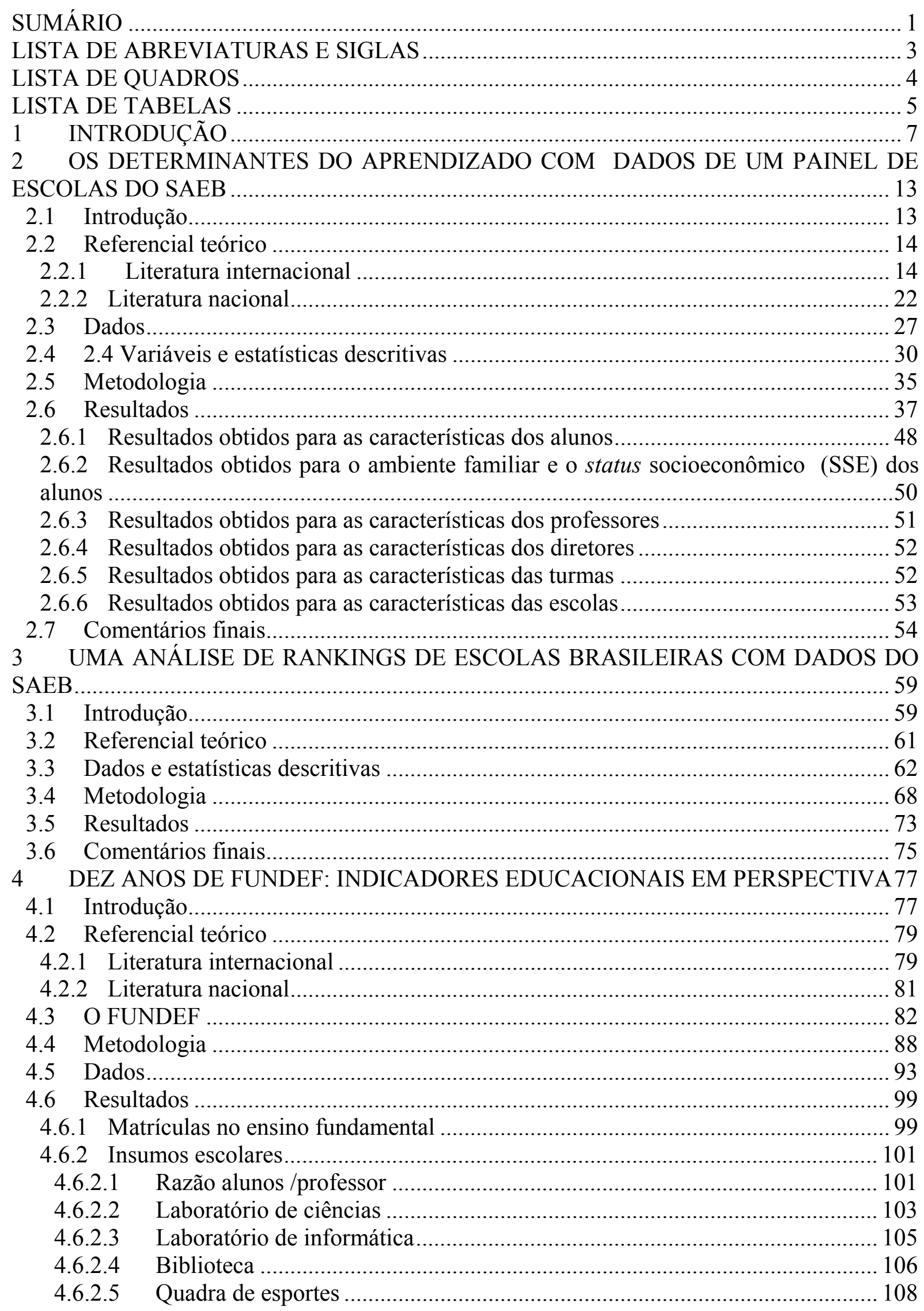




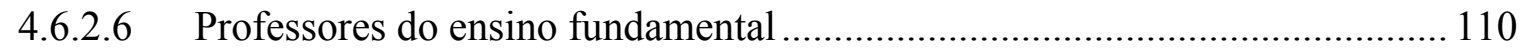

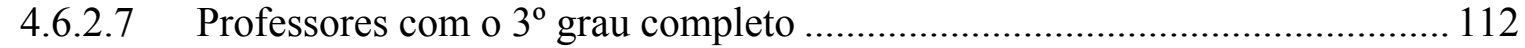

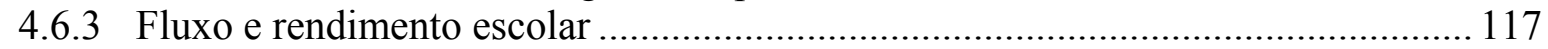

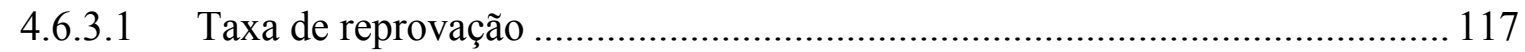

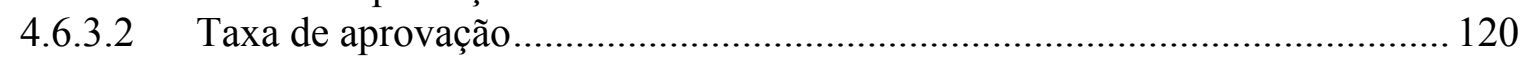

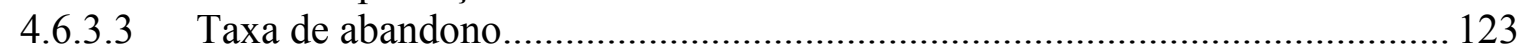

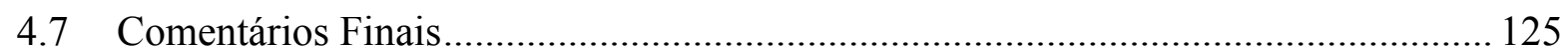

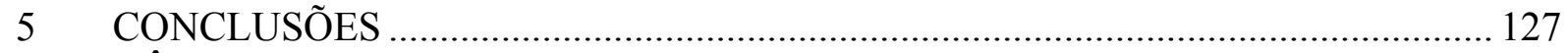

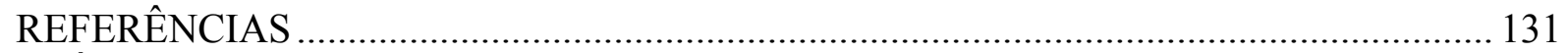

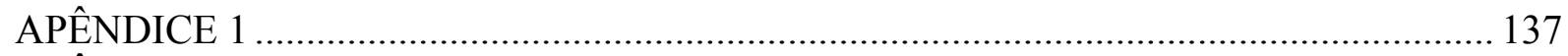

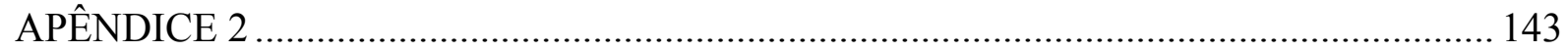




\section{LISTA DE ABREVIATURAS E SIGLAS}

DD: Estimador de diferenças em diferenças.

EF: Modelo de efeitos fixos.

EA: Modelo de efeitos aleatórios.

FINBRA: Finanças do Brasil. É o relatório das informações sobre despesas e receitas de cada município brasileiro, divulgadas pela Secretaria do Tesouro Nacional.

FUNDEF: Fundo de Manutenção e Desenvolvimento do Ensino Fundamental e de Valorização do Magistério.

IBGE: Instituto Brasileiro de Geografia e Estatística.

IDEB: Índice de Desenvolvimento da Educação Básica.

INEP: Instituto Nacional de Estudos e Pesquisas Educacionais Anísio Teixeira.

MQG: Mínimos Quadrados Generalizados.

MQO: Mínimos Quadrados Ordinários.

PISA: Programme for International Student Assessment.

MEC: Ministério da Educação.

SAEB: Sistema de Avaliação da Educação Básica.

SSE: Status socioeconômico. 


\section{LISTA DE QUADROS}

Quadro 1-Ranking das 10 melhores escolas de 1999

Quadro 2-Ranking das 10 melhores escolas de 2001

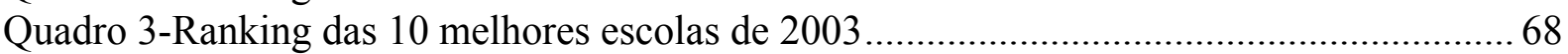

Quadro 4- Descrição de quatro medidas de desempenho de escolas obtidas por meio de

uma regressão 68

Quadro 5-Distribuições teóricas de freqüências percentuais do "número de vezes $(\mathrm{k})$ em que uma escola aparece entre as $20 \%$ melhores em 3 anos" nos casos de "certeza" e "loteria" comparadas com freqüências percentuais "número de escolas que aparecem k vezes/ número total de escolas (480)” segundo várias medidas.

Quadro 6-Distribuições teóricas de freqüências percentuais do "número de vezes $(\mathrm{k})$ em que uma escola aparece entre as $20 \%$ piores em 3 anos" nos casos de "certeza" e "loteria" comparadas com freqüências percentuais "número de escolas que aparecem k vezes/ número total de escolas (480)" segundo várias medidas 


\section{LISTA DE TABELAS}

Tabela 1 -Resultados de 96 estudos dos efeitos estimados de recursos escolares sobre a aprendizagem (países em desenvolvimento)

Tabela 2 -Levantamentos do SAEB

Tabela 3 - Número de escolas e alunos na $4^{\text {a }}$ série do ensino fundamental que fizeram a prova de matemática do SAEB nos anos de 1997, 1999, 2001, 2003 e 2005 ....... 30

Tabela 4-Número de alunos e de escolas por ano e por freqüência em que aparecem nas avaliações do SAEB dos dois principais painéis de dados analisados: 1997 a 2005 e 1999 a 2005

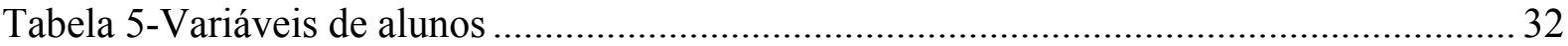

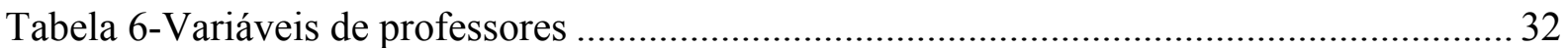

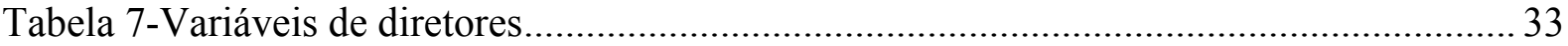

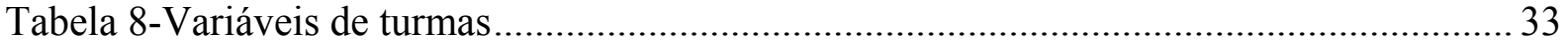

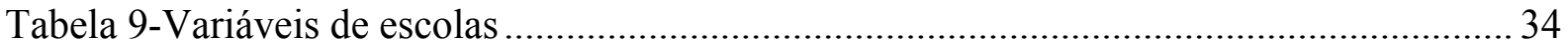

Tabela 10-Proficiência em matemática 4a série - escolas públicas (painel 1997, 1999, 2001,2003 e 2005)

Tabela 11- Proficiência em matemática $4^{a}$ série - escolas privadas (painel 1997, 1999, 2001,2003 e 2005)

Tabela 12- Proficiência em matemática $4^{a}$ série - escolas públicas (painel 1999, 2001, 2003 e 2005)

Tabela 13- proficiência em matemática $4^{\mathrm{a}}$ série - escolas privadas (painel 1999, 2001, 2003 e 2005)

Tabela 14- Matrículas na $4^{\mathrm{a}}$ série e sua evolução, por escola, na amostra de 480 escolas avaliadas pelo SAEB em 1999, 2001 e 2003

Tabela 15-Valores de R2 em ajustes por MQO de regressões de $\overline{\mathbf{y}}$ sobre SSE (escola)...... 70 Tabela 16-Valores de R2 em ajustes por MQO de 3 modelos de regressão linear da

variável resposta

Tabela 17-Cobertura dos municípios na FINBRA

Tabela 18-Número de municípios, escolas e grau de cobertura.............................................. 94

Tabela 19-Municípios e escolas com transferências líquidas positivas do FUNDEF. 
Tabela 20-Número de escolas na amostra

Tabela 21-Insumos das escolas de ensino fundamental do painel de municípios 1997-200596 Tabela 22-Insumos das escolas municipais apenas para aquelas que ganharam ou

perderam recursos do FUNDEF (1997-2005) ….............................................. 97

Tabela 23-Rendimento e fluxo escolar das escolas municipais e privadas (1997-2005)........ 98

Tabela 24-Rendimento e fluxo escolar das escolas municipais apenas ................................ 98

Tabela 25-Estimador DD da equação (4.2) para log (matrículas)......................................... 99

Tabela 26-Estimações por efeito fixo de município para log (matrículas) ............................. 100

Tabela 27- Estimador DD da equação (4.2) para log (razão alunos/ professor) .................... 101

Tabela 28-Estimações por efeito fixo de município para log (razão alunos /professor)........ 102

Tabela 29- Estimador DD da equação (4.2) para "laboratório de ciências" .......................... 103

Tabela 30-Estimações de efeitos fixos de município para "laboratório de ciências" ............. 104

Tabela 31- Estimador DD da equação (4.2) para "laboratório de informática"..................... 105

Tabela 32-Estimações de efeitos fixos de município para "laboratório de informática" ....... 106

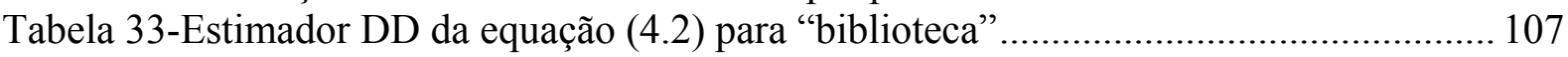

Tabela 34-Estimações por efeito fixo de município para "biblioteca" .................................. 108

Tabela 35- Estimador DD da equação (4.2) para "quadra de esportes"................................. 109

Tabela 36-Estimações por efeitos fixos de município para "quadras de esporte" ................. 110

Tabela 37- Estimador DD da equação (4.2) para "log ( professores no EF)" "........................ 111

Tabela 38-Estimações por efeitos fixos de município para "log ( professores no EF)" ....... 112

Tabela 39- Estimador DD da equação (4.2) para "professores de $1^{\mathrm{a}}$ a $4^{\mathrm{a}}$ com o $3^{\mathrm{o}}$ grau" $\ldots . .113$

Tabela 40- Estimador DD da equação (4.2) para "professores de $5^{\mathrm{a}}$ a $8^{\mathrm{a}}$ com o $3^{\circ}$ grau" $\ldots . .114$

Tabela 41- Estimações por efeitos fixos de município para "professores de $1^{\mathrm{a}}$ a $4^{\mathrm{a}}$ com o $3^{\circ}$

grau"

Tabela 42-Estimações por efeitos fixos de município para "professores de $5^{\mathrm{a}}$ a $8^{\mathrm{a}}$ com o $3^{\circ}$

grau" 116

Tabela 43-Estimador DD da equação (4.2) para "taxa de reprovação"

Tabela 44-Estimações por efeitos fixos de município para "taxa de reprovação".................. 119

Tabela 45- Estimador DD da equação (4.2) para "taxa de aprovação"................................. 121

Tabela 46- Estimações por efeitos fixos de município para "taxa de aprovação" ................. 122

Tabela 47- Estimador DD da equação (4.2) para "taxa de abandono" .................................. 123

Tabela 48- Estimações por efeitos fixos de município para "taxa de abandono" ................... 124 


\section{INTRODUÇÃO}

A preocupação com a qualidade do ensino púbico não é uma questão que se restringe aos países em desenvolvimento, que apresentam em geral elevadas taxas de analfabetismo, de distorção idade-série, de abandono, elevado contingente de crianças e jovens fora das escolas e condições precárias de ensino. No mundo desenvolvido também muito se estuda e discute como elevar a qualidade da educação pública, conhecidos que são seus efeitos sobre o crescimento econômico, a produtividade individual, a redução da criminalidade, o fortalecimento da democracia, a diminuição das desigualdades sociais dentre outras externalidades positivas.

Nos últimos anos o grande avanço na formação de banco de dados com informações sobre as escolas, seus professores, funcionários, alunos e o desempenho dos mesmos em testes padronizados, possibilitou o desenvolvimento de diversos estudos empíricos na área de educação, que têm contribuído cada vez mais para o entendimento dos determinantes do aprendizado e para a orientação de políticas educacionais. Como ponto de partida neste percurso de conhecimento sobre os determinantes do aprendizado, destaca-se o trabalho de grande envergadura realizado nos anos 60 nos Estados Unidos denominado Coleman Report.

O Coleman Report foi uma iniciativa do governo americano para tentar elucidar as questões da desigualdade na educação da população negra com relação à da branca. Buscava-se identificar os fatores passíveis de intervenção política para que se promovesse a eqüidade da qualidade do ensino. No entanto, os resultados do Relatório Coleman frustraram as expectativas de especialistas na área da educação e de estudiosos da questão da desigualdade na época, ao afirmar que as características das escolas e dos professores não tinham qualquer importância na determinação do desempenho escolar dos alunos. O estudo apontava que os fatores por trás do aprendizado dos alunos se resumiam às características socioeconômicas de suas famílias. Este resultado instigou muitos pesquisadores, que a partir de então se debruçaram sobre o tema para provar que os professores e as escolas podem, sim, fazer a diferença.

Muitas linhas de pesquisa conseguiram resultados importantes nesse sentido, contradizendo o relatório Coleman. Hanushek (ver, por exemplo, Hanushek et al.,1999; Hanushek e Rivkin, 
2004; Hanushek, 1995), um dos nomes que destaca em seus estudos a importância do professor no processo de aprendizado, contesta a forma de mensuração utilizada no relatório Coleman para realizar as estimações sobre o efeito-escola, e consegue mensurar o "efeitoprofessor" sobre o aprendizado (ver Hanushek et al., 2005b). Uma outra linha de pesquisa, para identificar os impactos que as características das escolas e professores exercem sobre o aprendizado dos alunos, é a que propõe o uso de modelos hierárquicos, como em Lee (2007a, 2007b). Por fim, os estudos realizados nos moldes de um experimento aleatório são a última novidade no campo de pesquisa sobre desenvolvimento econômico e educação (ver Benerjee e Duflo, 2008).

O presente trabalho também se propôs a mensurar os determinantes do aprendizado no caso brasileiro, com o uso de um painel de escolas construído a partir das informações do Censo Escolar e SAEB (Sistema de avaliação do ensino básico) para os anos de 1997, 1999, 2001, 2003 e 2005. Por se contar com um painel relativamente longo de dados, e lançando mão de modelos de regressão com efeitos específicos para contornar o problema de endogeneidade gerado por variáveis omitidas constantes no tempo, acreditava-se que seria possível captar variações nas características mensuráveis das escolas, turmas, diretores e professores que poderiam estar relacionadas ao desempenho dos alunos nas provas de matemática do SAEB para a $4^{\mathrm{a}}$ série do ensino primário. As estimações foram feitas para escolas particulares e públicas separadamente e não se conseguiu captar qualquer efeito de escola, turma, diretor ou professor no caso das escolas públicas.

Alguns resultados interessantes, porém, vieram à tona através das estimações realizadas no segundo capítulo. Ficou bastante clara a distinção dos efeitos que uma série de características socioeconômicas exercem sobre o desempenho de alunos nas escolas públicas e privadas. Quem está na escola pública consegue tirar um proveito muito menor de condições favoráveis de seu ambiente socioeconômico (por exemplo, a educação da mãe ou o fato de morar com os pais), do que quem está na escola privada. Por outro lado, os alunos que se declaram mulatos têm um desempenho melhor que os que se declaram brancos nas escolas públicas. Os negros, por sua vez, apresentam em geral o pior desempenho comparado aos mulatos e brancos, mas se saem muito pior se estudam numa escola privada do que se estudam numa escola pública.

Dos resultados do segundo capítulo pode-se inferir que, se os alunos das escolas públicas conseguem tirar menor proveito até das próprias condições socioeconômicas favoráveis que 
muitas vezes possuem, é porque a escola pública não lhes proporciona as condições ou a estrutura organizacional adequada para levá-los ao máximo aproveitamento de seus próprios recursos. Talvez nelas faltem os "incentivos" adequados a professores e diretores responsáveis pelo processo de aprendizado, como argumentam Hanushek (2002) e Barber e Mourshed (2007), por exemplo. Já nas escolas privadas, pode-se dizer que há um "enforcement" muito mais eficaz sobre os profissionais envolvidos na educação para que obtenham um bom desempenho e aproveitamento dos alunos. Acredita-se que o efeito escola específico não observado mas controlado nas estimações por Efeitos Fixos capte todo o processo não observado de casamento entre escolas, alunos, professores e diretores, que, combinados, fazem com que as escolas apresentem um bom ou mal desempenho.

Os resultados do capítulo 2 vão ao encontro do que se observa nas análises do capítulo 1, pois apontam também para uma elevada estratificação do sistema educacional, que acaba dificultando não somente que se atinja uma eqüidade na qualidade do ensino, mas também a obtenção de indicadores do desempenho escolar confiáveis para servirem de parâmetro às decisões da política e das famílias. Segundo alguns estudos realizados para o caso do Chile, como Mizala et al. (2007), pode existir um “trade-off” entre construir rankings de escolas que não espelhem majoritariamente a condição socioeconômica de seus alunos e, por outro lado, não apresentem muita volatilidade de um ano ao outro. A volatilidade tende a ocorrer devido a elevada estratificação social do sistema e ao problema de reversão para a média.

Segundo Chay et al. (2005) o fenômeno de "reversão para a média" faz com que o desempenho médio das escola em testes padronizados como o SAEB, Prova Brasil ou PISA possa variar muito de um momento de avaliação para outro. Escolas que se saem muito mal em um primeiro momento tendem a apresentar, numa avaliação seguinte, uma recuperação, enquanto que as que se saem bem em seguida tendem a apresentar um resultado ruim. Os autores demonstram que este efeito é tanto maior quanto menor é o número de alunos avaliados e maior a estratificação do sistema.

No capítulo 3 deste trabalho são calculadas cinco medidas de desempenho com base nos exames do SAEB de matemática para a $4^{\mathrm{a}}$ série, seguindo-se a abordagem dada por Mizala et al. (2007). São analisados se os rankings de escolas que emergem de tais medidas também apresentam o "trade-off" entre não refletir majoritariamente o status socioeconômico dos alunos e apresentar baixa volatilidade, como observado para o caso do Chile. Os resultados 
apontam que apenas uma das cinco medidas atende às condições de não refletir o status socioeconômico dos alunos e, ao mesmo tempo, apresentar baixa volatilidade. Porém, para que se possa afirmar com mais segurança que tal medida é a mais adequada para se construírem rankings de escolas no Brasil, seria necessário haver informações para um número maior de anos e, além disso, os dados deveriam ser preferencialmente de natureza censitária, como é o caso da Prova Brasil.

Avançando mais no debate de como elevar a qualidade do ensino nas escolas públicas, um dos pontos controversos na literatura é se são necessários mais recursos destinados à educação e ao pagamento de salários dos professores para que os bons profissionais sejam atraídos e mantidos nas redes públicas de ensino (ver por exemplo Guryan, 2002; Clotfelter et al.,2007, Hanuschek et al., 1999). No Brasil este debate também está presente. Porém, como a sociedade percebe uma carência muito grande de insumos escolares e de recursos em geral nas escolas públicas, além de uma grande heterogeneidade na qualidade, as políticas de financiamento da educação e de melhoria dos salários dos professores têm grande apelo junto à opinião pública e elaboradores de políticas educacionais.

No capítulo 4 do presente trabalho fez-se uso de uma mudança exógena na política de financiamento do ensino fundamental no Brasil a partir de 1998, que foi o FUNDEF, para analisar os impactos que maiores recursos destinados à educação a ao pagamento de salários dos professores exerceram sobre uma série de indicadores educacionais. Contando com um painel de 2.837 municípios para os quais há informações sobre as características de suas escolas públicas e privadas nos anos 1997, 1999, 2001, 2003 e 2005, estima-se o "efeitoFundef" pelo método de diferenças em diferenças simples e através do ajuste de quatro modelos de Efeitos Fixos. Os dados sobre as características das escolas são provenientes do Censo Escolar, enquanto os repasses líquidos do FUNDEF aos municípios são da base de dados do ministério da Fazenda denominada Finanças do Brasil (FINBRA)

Tomando-se as escolas municipais como grupo de tratamento e as escolas privadas (e /ou as escolas municipais cujos municípios não foram beneficiados por transferências líquidas positivas do Fundo) como grupo de controle, consegue-se captar o efeito-FUNDEF sobre as mudanças ocorridas tanto nos indicadores relacionados aos insumos das escolas quanto naqueles relacionados ao fluxo e rendimento escolar, que constituem bons parâmetros para se inferir sobre a qualidade do ensino. 
Os resultados obtidos no capítulo 4 apontam, em geral, para uma eficácia do FUNDEF em promover o aumento de insumos escolares no ensino fundamental, tais como laboratórios de ciências e informática, quadras de esportes e a proporção de professores com o $3^{\circ}$ grau, principalmente no ano seguinte à implementação do Fundo (1999). Ressalta-se ainda o resultado observado nas taxas de fluxo e rendimento escolar quando se comparam, em especial, os indicadores das escolas municipais cujos municípios ganharam recursos do Fundo (grupo de tratamento) com os das escolas municipais cujos municípios perderam recursos para o Fundo (grupo de controle): nos anos de 2001 e 2003 houve um aumento das taxas de aprovação e uma diminuição nas taxas de abandono nas escolas beneficiadas pelo FUNDEF; entretanto os efeitos sobre a taxa de repetência não se mostraram significativos.

Espera-se que as análises realizadas neste trabalho contribuam para o esforço em se apreender a realidade do ensino público no país, bem como para o desenho e elaboração de políticas educacionais eficazes no combate à desigualdade e baixa qualidade nas escolas públicas, problemas que grassam por todo o território nacional. Além desta introdução, o trabalho está dividido nas seguintes partes: o capítulo 2 traz o estudo sobre os determinantes do aprendizado com dados de um painel de escolas do SAEB, o capítulo 3 trata da análise dos rankings de escolas que emergem com base nos resultados do SAEB, o capítulo 4 trata dos efeitos de dez anos de FUNDEF sobre uma série de indicadores educacionais e o capítulo 5 apresenta as conclusões. 


\subsection{Introdução}

Desde que o INEP (Instituto Nacional de Estudos e Pesquisas Educacionais Anísio Teixeira, autarquia federal vinculada ao Ministério da Educação) passou a tornar público o ranking das escolas brasileiras, baseado no desempenho de alunos, a questão da qualidade da educação ganhou maior projeção na sociedade brasileira. Acalorou-se o debate entre os formuladores de políticas educacionais e os pesquisadores da área sobre as características das escolas que poderiam ser determinantes ou contribuir para explicar o diferencial de qualidade observado entre as escolas e, principalmente, quais delas seriam passíveis de intervenção política. Há muitas evidências sobre os impactos da qualidade da educação sobre a renda individual e crescimento econômico (ver HANUSHEK, 2005a; MULLIGAN, 1999; MURNANE et al., 2000; LAZEAR, 2003).

A questão sobre os fatores determinantes da qualidade do ensino sempre foi alvo de investigação, e alguns resultados importantes vieram à tona nos últimos anos, em estudos oriundos de diversas partes do mundo. Este trabalho procura jogar mais luz na investigação sobre a qualidade no ensino para o caso brasileiro. Utilizando-se dados dos exames do SAEB e do Censo Escolar (ambos levantados pelo INEP), neste capítulo procura-se estimar os efeitos sobre a proficiência dos alunos de diversas características de suas famílias, professores, diretores e escolas, controlando-se pelos efeitos não observáveis específicos de cada escola. Para tal utilizou-se um conjunto de dados em painel das escolas avaliadas nos exames do SAEB de 1997, 1999, 2001, 2003 e 2005.

Buscou-se um modelo de regressão linear que melhor descrevesse o efeito das características observáveis sobre a proficiência dos alunos, e a estimação dos coeficientes de regressão foi feita pelo método dos mínimos quadrados ordinários ou generalizados, conforme o caso. Por se tratar de dados de painel, os modelos considerados foram o modelo de regressão agrupado, 
o modelo de Efeitos Fixos e o modelo de Efeitos Aleatórios. Os resultados dessas estimações são analisados à luz de outros estudos feitos para o caso nacional.

Além desta introdução, este capítulo está dividido da seguinte forma: a seção 2.2 traz uma revisão da literatura internacional e nacional sobre a questão da qualidade no ensino; a seção 2.3 comenta as características dos dados do SAEB e Censo Escolar e traz as estatísticas descritivas das variáveis que entraram na análise; a seção 2.4 comenta a metodologia empregada; a seção 2.5 traz os resultados encontrados nas diversas análises e a seção 2.6 traz os comentários e algumas conclusões que podem ser tiradas a partir do estudo realizado.

\subsection{Referencial teórico}

\subsubsection{Literatura internacional}

Em 1966 foi realizada nos Estados Unidos uma grande pesquisa sobre educação promovida pelo Office of Education daquele país. O sociólogo James Coleman foi designado pelo Congresso dos Estados Unidos para levar a cabo um estudo em larga escala sobre as escolas americanas que recebiam alunos de diferentes raças no país. Acreditava-se, então, que intervenções sociais, financiadas pelo governo federal, pudessem corrigir as desigualdades entre brancos e negros, por exemplo. Os resultados a partir do Coleman Report surpreenderam aqueles que estavam preocupados em promover uma maior eqüidade no ensino. Concluiu-se que as diferenças nos recursos das escolas não eram muito relevantes para explicar a elevada desigualdade no aprendizado dos alunos de diferentes raças, e que o fator preponderante para explicar essa diferença seria o "background" familiar, em particular o status socioeconômico dos alunos. A visão predominante passou a ser a de que apenas as famílias e os colegas de classe podiam afetar o desempenho escolar. Um resultado positivo do Coleman Report foi de servir de incentivo para que muitos se propusessem a prová-lo equivocado, isto é, a demonstrar que as escolas faziam sim diferença (LEE, 2001, p. 38).

Hanushek (2002; 2005b), por exemplo, argumenta que no Coleman Report, bem como nos estudos posteriores que não conseguiram encontrar efeitos significativos de escolas e professores, teria havido uma confusão entre "mensurabilidade" e os verdadeiros efeitos das escolas sobre o aprendizado. O autor chama a atenção para dois resultados conclusivos em suas investigações: em primeiro lugar, há grandes e importantes diferenças entre os 
professores; em segundo lugar, essas diferenças não são captadas por medidas comuns de qualidade, tais como grau de qualificação e anos de experiência. Segundo sua definição de "qualidade", os bons professores são aqueles que obtêm grandes ganhos de desempenho dos alunos de suas classes, sendo professores ruins, em contraposição, aqueles que não obtêm bons desempenhos.

Hanushek (2002;2005b) argumenta que professores perto do topo da distribuição de qualidade conseguem o equivalente a um ano de conhecimento adicional por parte dos alunos comparativamente a professores no final da distribuição. Em outros termos, em um ano letivo normal, os professores bons conseguem fazer com que seus alunos adquiram o equivalente a um ano e meio de aprendizado escolar, enquanto os professores ruins conseguem fazer com que seus alunos aprendam apenas o equivalente a um semestre ${ }^{1}$.

Além disso, suas estimativas do desempenho dos professores sugerem que três anos seguidos de estudo com bons professores pertencentes ao $85^{\circ}$ percentil da distribuição de qualidade são capazes de fazer com que o déficit médio de desempenho observado entre as crianças pobres e as outras seja superado. Em outras palavras, professores altamente qualificados conseguem reverter os atrasos típicos que são observados na preparação de crianças com ambiente familiar desvantajoso (Id., 2002, p.3; Id., 2005b).

Hanushek (2005c, p.17-18) argumenta ainda que as evidências internacionais apresentam em geral os mesmos resultados obtidos nos estudos para os Estados Unidos, ou seja, de que não há uma relação consistente e sistemática entre recursos extras nas escolas e o desempenho dos alunos. "Os países em desenvolvimento, em geral, apresentam o pior desempenho e também os menores gastos com educação, o que faz com que muitas pesquisas prescrevam políticas de insumos. Além disso, os estudos sobre desempenho escolar existentes tendem a ser dificultados pela limitada disponibilidade de informações sobre a qualidade das escolas, características das famílias e avaliações de desempenho dos alunos, e ainda, pela dificuldade de realizar um acompanhamento do progresso de cada aluno ao longo dos anos e de relacionar este progresso à escola e aos seus professores (Ibid., p. 18)."

\footnotetext{
${ }^{1}$ A preocupação com a qualidade da educação teria ainda um apelo adicional: o fato de haver estudos indicando que a qualidade das escolas, mensurada pelo desempenho dos alunos em testes padronizados (e não apenas anos de escolaridade, como se costuma mensurar a variável proxy para capital humano) tem forte impacto sobre a produtividade individual e o crescimento econômico (ver HANUSHEK, 2005a).
} 
Outra linha de pesquisa tenta medir o efeito escola com o uso de modelos hierárquicos, como proposto em Lee (2001a; 2001b). Essa linha de pesquisa argumenta que os sistemas educacionais possuem uma estrutura hierárquica, na qual os estudantes estão agrupados em turmas, que por sua vez se agrupam em escolas, e que a utilização de técnicas analíticas de um único nível é muito limitante. As questões abordadas neste tipo de estrutura exigem um instrumental adequado para procurar relações entre fatores que operariam em distintos níveis como, no caso do sistema educacional, o nível do aluno, da turma (professores) e escolas ${ }^{2}$.

Lee (2001b) apresenta resultados de estudos feitos com alunos do segundo grau nos Estados Unidos, em que avalia o impacto do tamanho da escola sobre o aprendizado dos alunos em matemática e leitura, utilizando modelos hierárquicos. Segundo estes estudos haveria um tamanho ótimo de escola, com matrículas entre 600 e 900 alunos, tanto para o aprendizado em matemática quanto para aquele em leitura, sendo o efeito mais forte no caso do aprendizado de matemática. Assim, o efeito do tamanho da escola sobre o aprendizado seria não-linear: o aprendizado é mais baixo tanto em escolas muito pequenas quanto em escolas muito grandes. Além disso, para qualquer tamanho de classe, o aprendizado é maior nas escolas em que os alunos têm elevado nível socioeconômico, mas o tamanho ótimo é o mesmo, independentemente do nível econômico e social. Porém, o efeito do tamanho da escola sobre o aprendizado parece fazer maior diferença nas escolas com baixo nível econômico e social, um resultado bastante importante em termos de implicações de política.

Um outro aspecto da análise da qualidade das escolas sobre o aprendizado dos alunos em Lee (Ibid.) se refere à importância que tem os professores neste processo. Com base numa medida de como os professores definem seus alunos e seu trabalho, denominada de "responsabilidade coletiva", foram construídas médias escolares desta e outras medidas de organização social das escolas, com base nas respostas dadas pelos professores a vários itens de pesquisa. As

\footnotetext{
${ }^{2}$ Os problemas que surgiriam ao não se utilizarem métodos que levam em conta os níveis múltiplos seriam (ver Lee, 2001a): 1) O risco de haver "viés de agregação" ao se tentar capturar um fenômeno em um nível medindo-o em outro nível. Por exemplo, no caso de se obter uma medida das condições socioeconômicas individuais de cada criança, muitas vezes são utilizadas outras informações, como sua participação em programas sociais, porque as informações sobre a renda familiar não estão disponíveis (por uma série de razões). As escolas podem, entretanto, informar apenas a proporção de crianças que participam dos programas sociais, sem especificar quais são os alunos de baixa renda. Neste caso, a medida disponível em um nível, a condição socioeconômica média dos alunos da escola, não indica a condição socioeconômica de nenhum aluno individual e terá um significado diferente do que teria se pudesse ser medida no nível do aluno.

2) A estimação errada de desvios padrões ao se utilizarem análises individuais para um resultado que possui uma importante parte de sua variância devida a diferenças entre grupos. Com isso os desvios padrões associados aos testes de significância usuais dos parâmetros estimados estariam errados.

3) Problema de "heterogeneidade nas inclinações das regressões". Pode-se estar cometendo um erro ao assumir-se que a relação entre a variável dependente e a independente entre indivíduos é a mesma para qualquer grupo. As diferentes relações entre os grupos podem ser importantes de se explorar, o que seria uma poderosa vantagem dos MHL.

4) Os efeitos dos grupos seriam sistematicamente subestimados se utilizados métodos de um único nível para questões de níveis múltiplos. Se for justamente esse efeito dos grupos o objeto de interesse, seria menos provável que algum efeito seja achado.
} 
medidas de "responsabilidade coletiva" incluíram quatro idéias relacionadas: (1) a responsabilidade internalizada pelos professores para o aprendizado de seus alunos, ao invés da atribuição de suas dificuldades à baixa habilidade ou às condições domésticas desfavoráveis; (2) a crença de que o professor pode ser bem sucedido com qualquer aluno; (3) desejo de que sejam alterados os métodos de ensino frente às dificuldades de aprendizado e insucesso dos alunos; (4) cooperação entre professores; (5) o controle que os professores sentem possuir sobre as políticas da escola e do ensino. Os resultados encontrados apontam para uma forte relação positiva, consistente e significante entre "responsabilidade coletiva" e aprendizado dos alunos do $2^{\circ}$ grau nas disciplinas de matemática, inglês, estudos sociais e ciências.

No que diz respeito aos países em desenvolvimento, em geral há um ceticismo na literatura internacional quanto à capacidade de estudos retrospectivos capturarem os efeitos sobre o aprendizado, seja de insumos escolares ou de programas não realizados nos moldes de um estudo experimental ou aleatório. Glewwe e Kremer (2005) fazem um levantamento dos diferentes tipos de estudos empíricos realizados nos países em desenvolvimento sobre a influência que características de professores e escolas exercem sobre o aprendizado nas escolas primárias e secundárias. Dentre eles está o de Hanushek (1995), que revê 96 estudos com dados retrospectivos sobre os impactos, no desempenho dos alunos, dos seguintes insumos educacionais: razão aluno por professor, experiência do professor, salário do professor, gastos por aluno e facilidades de infra-estrutura. Hanushek conclui que, à exceção de "facilidades físicas", os recursos mensurados não estão sistematicamente relacionados com o desempenho dos alunos nos países em desenvolvimento. Os resultados resumidos de sua análise podem ser vistos na Tabela 1.

Tabela 1 -Resultados de 96 estudos dos efeitos estimados de recursos escolares sobre a aprendizagem (países em desenvolvimento)

\begin{tabular}{|c|c|c|c|c|}
\hline \multirow[t]{2}{*}{ Insumos } & \multirow[t]{2}{*}{$\begin{array}{l}\text { Número de } \\
\text { Estudos }\end{array}$} & \multicolumn{2}{|c|}{$\begin{array}{c}\text { Estatisticamente } \\
\text { Significante }\end{array}$} & \multirow[t]{2}{*}{$\begin{array}{l}\text { Estatisticamente } \\
\text { Insignificante }\end{array}$} \\
\hline & & Positivo & Negativo & \\
\hline Razão aluno-professor & 30 & 8 & 8 & 14 \\
\hline Educação do professor & 63 & 35 & 2 & 26 \\
\hline Experiência do professor & 46 & 16 & 2 & 28 \\
\hline Salário do professor & 13 & 4 & 2 & 7 \\
\hline Gastos por aluno & 12 & 6 & 0 & 6 \\
\hline Facilidades & 34 & 22 & 3 & 9 \\
\hline
\end{tabular}

Fonte: Hanushek (1995, p. 230) 
Porém, há razões para se acreditar que, à exceção da "taxa aluno-professor", os outros insumos exerçam um efeito positivo sobre a aprendizagem, pois é muito pequena a probabilidade de que tantos estudos apresentem estimativas positivas quando o verdadeiro parâmetro é zero ou negativo (KREMER, 1995). Outra interpretação possível é que talvez os estudos não estejam medindo os mesmos parâmetros, ou as estimativas sejam viesadas. Neste caso, dependendo da estimativa, os parâmetros estimados podem apresentar viés positivo ou negativo devido ao problema de variável omitida, por exemplo (GLEWWE; KREMER, 2005, p. 30).

Outro estudo com dados retrospectivos é o de Glewwe e Jacoby (1994), que analisou o desempenho dos alunos de 1988 a 1999 em Gana, usando as notas em leitura (inglês) e matemática nas escolas (de $7^{\mathrm{a}}$ a $10^{\mathrm{a}}$ série). Foram analisados os efeitos de 18 características de escolas e professores, mas os efeitos estimados foram pequenos e não significativos, em sua maioria. No caso das variáveis de professores, a única com efeito estatisticamente significante foi a experiência do professor, mas com efeito indireto: ela elevava a presença dos alunos na escola, o que aumentava suas notas de matemática e leitura. As facilidades nas escolas apresentaram impactos maiores, em especial o conserto de telhados, por diminuir o número de dias de aulas suspensas pelas chuvas. Também o número de lousas e a existência de biblioteca apresentaram impactos positivos.

Glewwe et al. (1995) usam dados de 1990 da Jamaica para estudar o desempenho de alunos do primário em leitura (inglês) e matemática. Foram examinadas mais de 40 características de professores e escolas, inclusive processos pedagógicos e estrutura administrativa. A maioria das variáveis apresentou efeitos não significativos. Dentre as que apresentaram efeitos significativos estão: treinamento do professor nos últimos 3 anos (em matemática apenas), testes acadêmicos de rotina nos estudantes (matemática e leitura), e o uso de livros-texto nas classes no caso das notas em leitura.

Kingdon (1996) analisa dados de 1991 sobre testes de leitura (hindu e inglês) e matemática aplicados para estudantes de $8^{\mathrm{a}}$ série na Índia. Neste estudo as seguintes características de escolas e professores são examinadas: anos de educação do professor, anos de treinamento do professor, notas do professor obtidas em exames oficiais, anos de experiência letiva, salário do professor, tamanho da classe, horas por semana de instrução acadêmica e um índice de 17 características físicas da escola. Nenhum dos reais impactos das variáveis se mostrou 
particularmente grande. As variáveis de professores com efeito significativo foram: notas do professor nos exames oficiais (efeito positivo em ambas as disciplinas) e anos de educação do professor (efeito positivo sobre as notas em leitura). Quanto às características das escolas, o índice de características físicas e horas de instrução acadêmica apresentaram efeitos positivos e significativos em ambas as disciplinas (leitura e matemática). O tamanho da classe (classes maiores) só se mostrou positivamente significante no que diz respeito às notas em leitura. $\mathrm{O}$ impacto das notas dos professores nos exames não se mostrou robusto quando se tentou controlar pela seleção nas escolas.

Por fim, Tan et al. (1997) usaram dados de 1990 e 1991 para analisar o impacto das características de escolas e professores sobre o desempenho de 2.293 alunos de $1^{\mathrm{a}}$ série nas Filipinas nos testes de matemática e leitura. As variáveis de professores incluídas na análise foram: qualificação do professor (se possui diploma de mestre), habilidade em raciocínio abstrato, notas dos professores em testes (com base nas disciplinas que lecionam), anos de experiência do professor e a atitude do professor em relação a "inovações no aprendizado". As variáveis de escolas foram: se as classes possuíam mobiliário suficiente (de acordo com a opinião do professor), a taxa aluno-professor, o valor do material pedagógico recebido por um programa do governo (PRODED), a disponibilidade de livros-texto por aluno, e quatro variáveis sobre as atitudes e práticas do diretor da escola. A variável de professor que apresentou efeito significativo foi a nota do professor no teste com base na disciplina que leciona (efeito positivo). Quanto às variáveis de escola, a taxa de livro-texto por aluno apresentou sinal positivo e significativo nas duas disciplinas, enquanto que a falta de mobiliário adequado apresentou efeito negativo e significativo no caso das notas em ambas as disciplinas.

Em todos os estudos com dados retrospectivos analisados por Glewwe e Kremer (Ibid.), a maioria das variáveis de escola e professores não apresentaram parâmetros significativamente diferentes de zero. Os autores alegam, porém, que isto pode decorrer do tamanho pequeno das amostras e de uma elevada correlação entre muitas das variáveis, além de grandes diferenças nos ambientes socioeconômicos dos países analisados e da variação na disponibilidade de algumas informações. Concluem que não existem resultados generalizáveis no que diz respeito a que variáveis de escola e de professor elevam o aprendizado em países em desenvolvimento. Ressaltam ainda que, os principais problemas de estimação que este tipo de análise enfrenta são a omissão de características das escolas e professores, características não- 
observadas das crianças e suas famílias, que são correlacionadas com características observáveis de escolas e professores, e erros de medida nas variáveis de escola e professores (Ibid., p.34).

Duas vertentes de pesquisas, que têm sido utilizadas nos últimos anos, buscam contornar os problemas de estimação encontrados nos estudos retrospectivos. São os chamados "experimentos naturais" e as "avaliações aleatórias" ou "randômicas". Os experimentos naturais fazem uso de variações exógenas nas características das escolas que, a princípio, não estariam correlacionadas com outros determinantes do aprendizado, para captar o impacto da qualidade da escola no desempenho dos alunos. As avaliações aleatórias mimetizam as condições de um experimento "em laboratório", em que os grupos de tratamento e controle são escolhidos de forma aleatória.

Angrist e Levy (1992), por exemplo, realizam um estudo em Israel sobre o impacto do tamanho da classe no desempenho dos alunos, nos moldes de um experimento natural. $\mathrm{O}$ tamanho das classes em cada série naquele país varia de forma peculiar (exógena), devido a uma antiga regra do século XII: as classes não deveriam exceder 40 alunos e, quando o número de matrículas na série atingisse 41 , a classe deveria ser divida em duas. Do mesmo modo, quando o total de matrículas em determinada série atingisse 81 alunos, as classes deveriam ser divididas em três turmas e assim por diante. Esta regra prevalece hoje nas escolas seculares de Israel. Deste modo, há menos espaço para que grupos de pais de alunos com poder político dentro das escolas influenciem na decisão quanto ao tamanho da classe que querem para seus filhos. Os autores utilizam esta regra como instrumento para o tamanho da classe para saber qual o impacto deste sobre o aprendizado. Os dados provêm de um exame israelita nacional para a $3^{\mathrm{a}}, 4^{\mathrm{a}}$ e $5^{\mathrm{a}}$ série. Angrist e Levy (Ibid.) encontraram um impacto negativo e significativo do tamanho da classe sobre as notas de alunos de $5^{\text {a }}$ série em matemática e leitura. Para a $4^{\mathrm{a}}$ série os efeitos não se mostraram claros, e para a $3^{\mathrm{a}}$ série deram insignificantes.

$\mathrm{Na}$ linha dos experimentos naturais encontram-se, por exemplo, os trabalhos realizados no Abdul Latif Jameel Poverty Action Lab, do departamento de economia do Instituto de Tecnologia de Massachusetts (ver Banerjee e Duflo, 2008). As pesquisas experimentais no campo do desenvolvimento econômico iniciaram-se a partir da preocupação quanto à confiabilidade da identificação dos efeitos de políticas diante dos inúmeros e intrincados 
canais de causalidade. Os experimentos permitem variar um fator em um tempo e então prover "internamente" estimativas válidas de efeitos causais. No que diz respeito à economia da educação, os experimentos procuram responder questões sobre a função de produção de educação tais como: se melhores insumos (livros-texto, mobiliário, diminuição da taxa alunoprofessor etc) têm importância para os resultados escolares (em termos de desempenho dos alunos, presença, redução do abandono etc) e em que dimensão.

Pode-se citar os seguintes resultados obtidos por experimentos naturais em países em desenvolvimento na área de educação:

1) Segundo Banerjee e Duflo (2008), melhorar o acesso a livros-texto, de um livro para quatro ou mais alunos para um livro por dois alunos, não afeta a nota média nos exames. Nem mesmo diminuir para a metade a taxa de aluno-professor afeta a nota média nos exames, segundo Banerjee et al. (2005).

2) De acordo com o estudo de Miguel e Kremer (2004), o tratamento para vermes intestinais em escolas do Quênia, ao custo de US\$ 49 centavos por criança por ano, pode reduzir o absenteísmo em 25\%. Em termos de aumentar a presença, o estudo mostra que tratar os vermes é quase 20 vezes mais eficaz que contratar um professor extra.

3) Um boletim do Abdul Latif Jameel Poverty Action Lab ( 2005) compara o custo por criança de um ano extra de educação induzido por um conjunto de diferentes estratégias. Os custos variam de US\$ 3,50 por um ano extra de educação por tratar os vermes à US\$ 6.000 por um ano extra por criança para o componente da educação primária do PROGRESA (Programa de Transferência Condicional de Renda no México) ${ }^{3}$. Segundo ainda o boletim, o custo de um ano extra por criança advindo da entrega de um uniforme grátis foi de US\$ 100 por aluno.

4) O estudo de Glewwe et al. (2003) alerta para a cautela que se deve ter quando o programa busca dar incentivos aos professores, para que faltem menos ou ensinem com mais motivação, com base nos resultados de testes aplicados aos alunos. $\mathrm{O}$ que eles mostraram é que isto pode fazer com que os professores ensinem com foco nos exames de desempenho apenas, ou que podem ocorrer outras manipulações de curto prazo das notas nos testes, que não têm impactos consistentes e de longo prazo sobre a qualidade do ensino de fato.

5) Duflo et al. (2007), por outro lado, propuseram uma estratégia diferente para diminuir o absenteísmo dos professores numa área da Índia com população esparsa e onde as escolas são de difícil acesso: propuseram o uso de câmeras que marcam data e hora. Os professores

\footnotetext{
${ }^{3}$ Vale lembrar, porém, que o PROGRESA visava outros objetivos que não só a presença das crianças na escola.
} 
deveriam tirar uma foto de si com a turma de manhã e à tarde. O salário do professor era uma função não linear do número de dias com sua presença. A falta dos professores caiu de $40 \%$ para $20 \%$, e houve melhora no desempenho dos alunos.

6) Berry (2008) realizou um estudo nas favelas de Deli e constatou que dar uma recompensa, na forma de brinquedo, para crianças com desempenho fraco, é mais eficaz, em termos de melhorar suas notas nos exames, do que premiar seus pais dando a eles dinheiro.

Porém, há muitas críticas também à literatura de experimentos aleatórios. Experimentos naturais e avaliações aleatórias proporcionam estimativas mais confiáveis dos efeitos sobre o aprendizado da qualidade nas escolas, mas os resultados obtidos em um país dificilmente podem ser generalizados para outros com condições socioeconômicas e ambientais muito distintas. Além disto, a comparação dos custos e benefícios de diferentes políticas educacionais acabam se restringindo a um único país em que múltiplos experimentos podem ser realizados. Para uma discussão mais abrangente sobre as vantagens e as críticas aos experimentos aleatórios ver Heckman (1992) e Banerjee e Duflo (2008).

\subsubsection{Literatura nacional}

A questão da educação no Brasil sempre foi muito enfatizada nos estudos sobre o crescimento econômico, a desigualdade, pobreza, criminalidade, trabalho infantil, consolidação da democracia etc. Grande parte desses estudos preocupou-se em estimar os efeitos da educação em termos quantitativos e não qualitativos, ou seja, o nível educacional é utilizado em termos de anos de estudo ou ciclos completos de escolaridade. Isto se deve, primeiramente, ao fato de que no país ainda existe um déficit significativo de escolaridade da população (em termos de média de anos de estudo) frente a economias desenvolvidas e, portanto, há uma preocupação em se superar este hiato.

Na segunda metade do século XX dois estudos no Brasil se destacaram como importantes fontes de referência na análise da importância da educação para o desenvolvimento do país. Castro (1970) estudou a questão do perfil dos salários, os custos da educação e por fím a taxa interna de retorno da educação (TIR) ${ }^{4}$. O autor constatou que esta última era extremamente elevada e que, portanto, o investimento em educação no país deveria ser fortemente

\footnotetext{
${ }^{4}$ Taxa Interna de Retorno da educação calculada como a taxa de retorno que iguala o valor presente dos custos de um ano a mais de educação com o valor presente dos benefícios deste ano adicional de estudo.
} 
estimulado. No outro estudo de referência, Langoni (1974) analisou as questões do desenvolvimento brasileiro e calculou a taxa interna de retorno do investimento em educação e capital fixo. Assim como em Castro (op. cit.,1970), seus resultados apontaram para a elevada taxa de retorno da educação nos anos sessenta e setenta, e para a necessidade de se investir mais em educação como forma de promover o crescimento do país.

Num estudo mais recente, que utiliza a mesma metodologia que Castro (Ibid.) e Langoni (Op . cit), Barbosa Filho e Pessoa (2006) calculam a taxa interna de retorno da educação para o Brasil para o período que vai dos anos oitenta a 2004. Seus resultados apontam que o retorno da educação se manteve muito elevado, mas que os ciclos de maior retorno deixaram de ser o primário e o ginásio e passaram a ser o secundário e o universitário. Este último foi o que apresentou o maior crescimento comparativamente à década de sessenta: de um patamar inicial de 4,9\% a taxa interna de retorno da educação atingiu $18 \%$ em $2003^{5}$. Segundo o autor, a diminuição na taxa interna de retorno do primário se explicaria por dois fatores: teria havido um aumento da oferta de mão-de-obra com primário completo nas últimas décadas e uma queda da demanda por trabalhadores pouco qualificados decorrente da revolução tecnológica da economia da informação iniciada na década passada. Por outro lado, o grande aumento no retorno da educação superior refletiria a maior demanda por trabalhadores de maior qualificação.

Pode-se argumentar, porém, que as alterações observadas nas diferentes taxas de retorno de cada ciclo ao longo do período analisado não captam possíveis alterações na qualidade do ensino no país. Até que ponto a queda nos retornos do ensino primário (e a elevação do retorno do ensino superior) não se deveu também a uma piora na qualidade do ensino fundamental? Em geral os estudos que analisam a qualidade do ensino focam o desempenho acadêmico nas provas aplicadas por sistemas públicos de avaliação da educação. Para mensurar o aprendizado ou o conhecimento adquirido, é necessário que haja informações sobre o nível inicial de conhecimento do aluno, bem como avaliações posteriores para acompanhar o seu progresso. Porém, no caso do Brasil e dos principais levantamentos de dados sobre o sistema educacional realizados pelo governo federal, estados e municípios, essas informações não estão disponíveis.

\footnotetext{
${ }^{5}$ Para os outros ciclos os resultados foram os seguintes: em 1960 a taxa de retorno da educação no primário era de quase $50 \%$ e cai até 2003 , quando atinge 10,8\%; para aqueles com o ginásio completo a taxa de retorno caiu de $24 \%$ em 1960 para $12 \%$ em 2003; no secundário a taxa interna de retorno sofre grande elevação no começo da década de oitenta, cai na década de noventa e atinge $15 \%$ em 2003 , o mesmo nível de 1960.
} 
Em Menezes-Filho (2007) encontra-se uma análise da evolução da realidade educacional brasileira, de 1960 até os primeiros anos do século XXI, e sua comparação com a realidade internacional, bem como um estudo econométrico para o Brasil dos fatores que, em geral, estariam associados à qualidade da educação nas escolas, com base em dados do SAEB 2003. Num exercício de decomposição de variância das notas no SAEB de 10 estados brasileiros e Distrito Federal, sem controlar por características dos alunos e suas famílias, estima-se que, em média, cerca de $20 \%$ das variações de notas dos alunos das escolas públicas se deva a diferenças entre escolas dentro de um mesmo estado, e os restantes $80 \%$ a diferenças entre os alunos dentro de uma mesma escola. Após o controle por diferenças socioeconômicas dos alunos e suas famílias, diminui para $15 \%$ a parcela média da variação devida a diferenças entre as escolas ${ }^{6}$.

Em Felício e Fernandes (2006) também se busca medir o "efeito escola" com os dados do SAEB 2001, para os alunos da $4^{\text {a }}$ série do Estado de São Paulo. Um dos métodos utilizados para mensurar esse efeito é também a decomposição da desigualdade de notas entre as diferenças nas características dos alunos e suas famílias e as diferenças nas escolas que os alunos freqüentam. Com isso, os autores constroem um intervalo de confiança para a proporção da desigualdade de desempenho que poderia ser explicada por diferenças entre as escolas. O intervalo de confiança $(0,95)$ para a proporção da desigualdade de desempenho devido ao efeito escola foi $(8,6 \% ; 34,4 \%)$ no caso da proficiência em matemática e $(0 \%$; $28 \%$ ) no caso da proficiência em língua portuguesa.

Entre os estudos voltados para identificar os insumos escolares que estariam associados a um melhor desempenho dos alunos nas escolas, Biondi e Felício (2007), utilizando um painel de escolas, estimam um modelo de regressão com os dados agrupados por Mínimos Quadrados Ordinários agrupados e um modelo de Efeitos Fixos com identificação das escolas como uma variável regressora adicional, utilizando as médias por escola das notas de alunos da $4^{\mathrm{a}}$ série na prova de matemática como variável dependente e, como variáveis regressoras, a média (ou proporção no caso de variáveis dummies) das características observáveis de professores, diretores e escolas a partir dos dados do SAEB e Censo Escolar dos anos 1999, 2001 e 2003. Em suas estimações no modelo de regressão com Efeito Fixo de escola e a partir de um painel

\footnotetext{
${ }^{6}$ Sem os controles pelas características socioeconômicas dos alunos e suas famílias, a parcela de variação das notas entre escolas vai de $12 \%$ no DF a $30 \%$ no Tocantins. Com os controles a parcela entre escolas cai e passa a variar entre $8 \%$ no DF até $20 \%$ no RJ
} 
composto por 260 escolas públicas, encontram poucos efeitos significativos dos atributos escolares que entraram nas regressões, a saber: um efeito positivo e significante a $5 \%$ no caso de a escola apresentar baixa rotatividade de professores, efeito positivo e significante a $5 \%$ do corpo docente ter experiência média superior a dois anos, efeito positivo e significante a $1 \%$ da escola ter Internet, um efeito negativo e significante a $1 \%$ da escola ter laboratório de informática, e um efeito positivo e significante a $1 \%$ do diretor ter assumido o cargo por “outras formas”, que não por concurso público, seleção, eleição ou indicação. Talvez pela característica da amostra (apenas alunos de escolas públicas) e pelo curto período analisado (três avaliações), as demais variáveis como as características socioeconômicas dos alunos, escolas, professores e diretores, não tenham apresentado uma variação suficiente para ser captada nas estimações. Ou também, como ressaltam as autoras, pode ser que tais atributos não exerçam mesmo influência sobre o aprendizado, uma vez controladas as variáveis específicas e não observáveis das escolas.

Já Sátyro e Soares (2008) também utilizam um painel de escolas e encontram forte impacto da infra-estrutura no desempenho escolar nas escolas brasileiras que oferecem ensino fundamental. Os autores utilizam como variável dependente a distorção idade-série, e como variáveis regressoras os insumos escolares, aos quais se referem como "tudo aquilo que o dinheiro pode comprar": formação docente, existência de biblioteca ou sala de leitura, material pedagógico, tamanho da turma, horas-aula. Como variáveis de controle usam as informações do Censo de 2000 para obterem características socioeconômicas dos municípios. Utilizando um painel de escolas a partir das informações do Censo Escolar de 1995 a 2005, estimam vários modelos de regressão. Os resultados encontrados sob o modelo de Efeitos Fixos de escola mostram forte impacto das variáveis regressoras sobre a taxa de distorção idade série. Porém, como neste caso não foram feitos os controles sobre as características socioeconômicas dos alunos ou da população à qual a escola serve, pode haver viés de variável omitida mesmo controlando-se pelo Efeito Fixo Escola. Como mostraremos nos nossos resultados adiante, as características socioeconômicas dos alunos contribuem fortemente para o aprendizado ou desempenho dos alunos (que seria inversamente relacionado à distorção idade-série ou à repetência escolar), mesmo após o controle por efeitos específicos não-observados das escolas. Além disso, a taxa de distorção idade-série não é a medida ideal de qualidade no ensino. Algumas escolas podem reprovar mais que outras, e alunos podem iniciar os estudos mais atrasados, principalmente em regiões rurais. 
No que diz respeito ao uso de modelos hierárquicos, Soares et al. (2001) analisam o desempenho das escolas de ensino médio do Estado de Minas Gerais, que forneceram alunos para os vestibulares da UFMG de 1998, 1999 e 2000, e encontram fortes indícios de que as práticas e políticas das escolas secundárias fazem a diferença. Soares (2003) buscou as características dos professores e do ambiente em sala de aula que teriam influência sobre o desempenho dos alunos da $4^{\text {a }}$ série do ensino fundamental na disciplina de português, utilizando a base de dados do Sistema Mineiro de Avaliação da Educação Pública (SIMAVE) para o ano de 2002. Seus resultados indicam que grande proporção da variação dos "escores" é explicada pelos aspectos em sala de aula, e que as características dos professores explicam parcela substancial desta variabilidade.

Soares (2005) estendeu a análise anterior para capturar os efeitos dos três níveis hierárquicos de informações: alunos, turmas (professores) e escolas. O autor argumenta que o ganho na explicação da variabilidade devido à inclusão das variáveis de escola foi relativamente pequeno quando comparado ao ganho obtido com a introdução de variáveis de turma e aluno. No que diz respeito às características dos alunos, os meninos e os alunos de raça negra se saem pior nas provas de português. Além disso, as variáveis que indicam o nível econômico e social têm influência positiva sobre o desempenho, a defasagem escolar tem influência negativa e o fato do aluno participar do programa bolsa escola tem influência negativa. Quanto ao ambiente da sala de aula, professores faltosos e a falta de motivação dos alunos afetam negativamente o desempenho, enquanto professores mais dedicados, disponíveis e aqueles que exigem deveres de casa afetam positivamente. Quanto às características das escolas, a média de idade do corpo docente apresentou influência negativa, enquanto que a porcentagem de professores que participam de educação continuada e o índice de posse de equipamentos de informática na escola apresentaram impactos positivos. Em Soares e Mendonça (2003) chega-se a resultados similares aos acima apontados com o uso dos dados do SIMAVE 2000. Em geral, o resultado desses estudos com modelos hierárquicos vão ao encontro daqueles obtidos com as análises que utilizam o instrumental microeconométrico como, por exemplo, Menezes-Filho (2007).

Na literatura nacional sobre educação, portanto, a questão da qualidade do ensino e da contribuição das escolas e professores para o aprendizado dos alunos tem sido bastante explorada. Porém, faz-se necessário continuar o esforço no sentido de avançar o debate sobre como melhorar os gastos em educação, para que estes não apenas aumentem sua participação 
no total dos gastos públicos, mas efetivamente promovam a melhoria da qualidade e equidade do ensino no país.

Partindo-se do pressuposto de que insumos escolares contribuem de alguma maneira para o aprendizado (já que não existe um consenso nem na literatura internacional e nem na nacional sobre este ponto), e utilizando-se o método de Efeitos Fixos (que melhor pode minorar os inúmeros problemas que cabem no termo de "endogeneidade" nas estimações com dados retrospectivos), construiu-se um painel de escolas para um período de cinco anos de avaliações no SAEB e Censo Escolar e buscou-se avaliar o impacto sobre o desempenho dos alunos de uma série de insumos escolares. Esses insumos vão desde características dos professores, turmas, diretores e atributos físicos da escola até os programas sociais dos quais ela participa. Pelo fato de contar com um painel mais longo de dados do SAEB até aqui estudados, mais informações que incluem as características socioeconômicas do corpo discente, e de se realizar estimações com as observações individuais de cada aluno em cada escola, e não apenas com as médias por escolas, acredita-se que se este trabalho traz novos ingredientes e contribuições para a análise do caso nacional.

\subsection{Dados}

Os dados utilizados nesta pesquisa provêm do Sistema Nacional de Avaliação da Educação Básica (SAEB) e também do Censo Escolar. Criado em 1988, o SAEB é desenvolvido pelo Instituto Nacional de Estudos e Pesquisas Educacionais Anísio Teixeira (INEP), na sua Diretoria de Avaliação da Educação Básica (Daeb), e contem dados sobre alunos, professores, diretores de escolas públicas e privadas em todo o Brasil.

O SAEB é aplicado a cada dois anos e desde 1993 avalia o desempenho dos alunos brasileiros da $4^{\mathrm{a}}$ e da $8^{\mathrm{a}}$ séries do ensino fundamental e da $3^{\mathrm{a}}$ série do ensino médio, nas disciplinas de língua portuguesa (Foco: leitura) e matemática (Foco: resolução de problemas). Já foram realizados sete levantamentos $(1993,1995,1997,1999,2001,2003$ e 2005), que sofreram aperfeiçoamentos em cada aplicação, tanto do ponto de vista metodológico como nos procedimentos, operacionalização e abrangência (INEP, 2008). 
Segundo INEP (2007), até 1995 a metodologia utilizada para elaboração das amostras e provas não permitia que fossem comparados os resultados de um ano a outro. Fazia-se então uma "meta-análise" dos dados em que os resultados eram analisados separadamente a cada ano, sendo possível posteriormente notar a existência de traços comuns entre as avaliações como, por exemplo, se os alunos se saíam bem ou mal em determinados conteúdos. A partir de 1995 foram adotadas técnicas que passaram a permitir a comparabilidade dos resultados das avaliações nas séries históricas: foi introduzido o uso da Teoria de Resposta ao Item (TRI) para a construção de instrumentos, a atribuição de escores e a análise, para permitir a comparação dos dados. Os resultados obtidos a partir da TRI são independentes de grupos e não são afetados pela dificuldade dos testes. A comparabilidade é garantida por meio da inclusão de itens comuns às avaliações de edições anteriores, o que recebe o nome de "equalização de grupos não equivalentes com itens comuns". Utilizam-se matrizes de referência como instrumentos, que servem de orientação para a construção e seleção dos itens de avaliação.

Os procedimentos de amostragem são baseados em metodologia científica, que garante a precisão nas estimativas dos parâmetros populacionais. Tratam-se de amostras aleatórias, probabilísticas e representativas da população de referência. Esta, por sua vez, compõe-se dos alunos brasileiros do ensino regular que freqüentam a $4^{\mathrm{a}}$ e $8^{\mathrm{a}}$ séries do ensino fundamental e a $3^{\mathrm{a}}$ série do ensino médio, de todas as unidades da federação.

Em cada levantamento do SAEB houve alterações na população de referência e nas definições das amostras. Porém, de acordo com o INEP (2007), mantiveram-se estruturas similares para que fosse possível a comparação entre os anos dos diversos levantamentos. A Tabela 2 mostra algumas das características desses levantamentos.

Tabela 2 -Levantamentos do SAEB

\begin{tabular}{|c|c|c|c|c|c|}
\hline \multirow[t]{2}{*}{ Ano } & \multirow[t]{2}{*}{ Número de escolas } & \multicolumn{4}{|c|}{ Número de Alunos } \\
\hline & & $4^{\mathrm{a}}$ série & $8^{\mathrm{a}}$ série & $3^{\circ}$ colegial & Total \\
\hline 1995 & 2.839 & 30.749 & 39.482 & 26.432 & 96.663 \\
\hline 1997 & 1.933 & 70.445 & 56.490 & 40.261 & 167.196 \\
\hline 1999 & 6.798 & 107.657 & 89.671 & 82.436 & 279.764 \\
\hline 2001 & 6.935 & 114.512 & 100.792 & 72.415 & 287.719 \\
\hline 2003 & 5.598 & 92.198 & 73.917 & 52.406 & 218.521 \\
\hline 2005 & 5.940 & 83.929 & 66.353 & 44.540 & 194.822 \\
\hline
\end{tabular}

Fonte: INEP (2005) 
Nos diversos anos em que o SAEB é realizado, algumas escolas se repetem nas amostras. Isto permite que se explore a metodologia para análise de dados em painel, de forma a buscar maior precisão nos parâmetros de interesse. As estimativas dos efeitos de variáveis regressoras observáveis apenas com dados referentes a cross sections, como é comum no caso dos estudos sobre insumos de educação no Brasil, não permitem o controle de características não observáveis nas escolas. Isso pode fazer com que essas estimativas apresentem viés de variável omitida. Se as variáveis omitidas não estiverem correlacionadas com os demais regressores, é possível obter estimadores consistentes dos coeficientes de um modelo de regressão contendo apenas as variáveis observáveis por Mínimos Quadrados Ordinários, ainda que eles não sejam os estimadores mais eficientes . Porém, no caso de haver características não observáveis das escolas, é muito pouco provável que elas não estejam correlacionadas com as características observáveis da escola, seu corpo discente, corpo docente e diretores, que se alteram no tempo, e esse fato impõe o uso de um modelo de regressão que contemple a existência de efeitos específicos não observáveis.

Este trabalho irá utilizar os dados do SAEB referentes às escolas (rede pública e privada) onde foram aplicadas as provas de matemática para a $4^{\mathrm{a}}$ série do ensino fundamental nos anos de 1997, 1999, 2001, 2003 e 2005, em todas as unidades da federação. Uma das maiores dificuldades em se construir um painel de escolas com os dados do SAEB é compatibilizar as respostas dos dicionários (alunos, professores, diretores, turmas e escolas) nos diferentes anos sem se abrir mão de variáveis que são importantes na função de produção escolar. Portanto, serão reportados também os resultados obtidos com um painel mais curto de escolas, referente aos anos 1999, 2001, 2003 e 2005, no qual há maior proximidade nas perguntas, o que permite que sejam explorados os efeitos de mais variáveis explicativas, e onde também é maior o número de escolas que se repetem.

Para completar o rol de informações referentes às escolas que vão entrar na análise de painel, foram incluídos os dados disponíveis no Censo Escolar (INEP) que, apesar de não conterem informações sobre a proficiência dos alunos (variável crucial para a analise deste trabalho), contêm informações sobre algumas características observáveis das escolas, seus alunos e professores.

O Censo Escolar é realizado anualmente pelo Instituto Nacional de Estudos e Pesquisas Educacionais Anísio Teixeira (INEP/MEC), em parceria com os governos estaduais 
(secretarias estaduais de educação) e prefeituras municipais. Ele contém informações sobre características das escolas, como insumos de produção e infra-estrutura, composição do corpo docente em termos de modalidade de ensino, níveis de instrução dos professores, desempenho acadêmico dos alunos, número de matrículas e turmas nos diferentes turnos entre outras.

\section{$2.4 \quad 2.4$ Variáveis e estatísticas descritivas}

A Tabela 3 traz informações sobre o número de escolas e alunos da $4^{\text {a }}$ Série que passaram pela avaliação do SAEB na disciplina de matemática para todo o Brasil nos anos de 1997, 1999, 2001, 2003 e 2005 e que compõem um painel de escolas ${ }^{7}$.

Tabela 3 - Número de escolas e alunos na $4^{\text {a }}$ série do ensino fundamental que fizeram a prova de matemática do SAEB nos anos de 1997, 1999, 2001, 2003 e 2005

\begin{tabular}{ccccccc}
\hline Observações & \multicolumn{6}{c}{ Ano } \\
& 1997 & 1999 & 2001 & 2003 & 2005 & Total \\
\cline { 2 - 7 } Escolas & 1.065 & 4.048 & 3.933 & 3.167 & 2.811 & $\mathbf{1 5 . 0 2 4}$ \\
Aluno & 23.535 & 21.150 & 53.357 & 42.711 & 41.783 & $\mathbf{1 8 2 . 5 3 6}$ \\
\hline
\end{tabular}

Como o SAEB tem caráter amostral, muitas escolas não se repetem em todos os anos realizados. Desta forma, para se utilizar a metodologia de dados em painel e prosseguir nas investigações às quais este trabalho se propõe, a análise será feita utilizando-se quatro conjuntos de dados:

1) Painel de escolas com dados dos anos 1997, 1999, 2001, 2003 e 2005, separado para escolas públicas e privadas

2) Painel de escolas para os anos 1999, 2001, 2003 e 2005, separado para escolas públicas e privadas.

Para trabalhar com um painel de escolas, foram excluídas aquelas que só apareciam uma vez nos cinco anos compreendidos no período 1997-2005 (42,64\% do total da amostra). Foram consideradas apenas as escolas que apresentavam número de matrículas na $4^{\mathrm{a}}$ série no Censo

\footnotetext{
${ }^{7}$ Ao se buscar juntar as informações existentes no SAEB e Censo Escolar sobre escolas, alunos, professores, diretores e turmas, perderam-se algumas observações em alguns anos por conta do casamento imperfeito entre os diversos bancos. Por exemplo, o número de escolas e seus alunos antes de se juntarem as informações de diretores, professores, turmas e escolas eram, respectivamente: 4.075 e 21.180 em 1999 , 4.045 e 54.371 em 2001, 3.260 e 43.689 em 2003 , 2.811 e 41.783 em 2005. No ano de 1997 valem os mesmos números reportados na Tabela 2.
} 
Escolar maior ou igual a dez, e no mínimo uma turma desta série em cada escola, de forma a tentar minimizar o problema de erro que existe na computação de dados como o Censo Escolar ${ }^{8}$. Além disso, foram excluídas as escolas federais, que representavam menos de $0,4 \%$ no total das escolas e que apareciam apenas nos anos de 2003 e 2005 . A Tabela 4 traz o número de escolas por freqüência nos anos e por ano que permaneceram nas sub-amostras utilizadas nos painéis.

Tabela 4-Número de alunos e de escolas por ano e por freqüência em que aparecem nas avaliações do SAEB dos dois principais painéis de dados analisados: 1997 a 2005 e 1999 a 2005

\begin{tabular}{lcccccc}
\hline \multirow{2}{*}{ Ano } & Total de alunos & Total de Escolas & \multicolumn{5}{c}{ Freqüência de escolas nas avaliações } \\
\cline { 3 - 7 } & & & $\mathbf{2}$ anos & $\mathbf{3}$ anos & $\mathbf{4}$ anos & $\mathbf{5}$ anos \\
1997 & 9.407 & 361 & 184 & 116 & 51 & 10 \\
1999 & 7.906 & 1.216 & 705 & 394 & 107 & 10 \\
2001 & 27.583 & 1.798 & 1.140 & 528 & 120 & 10 \\
2003 & 17.233 & 1.162 & 647 & 398 & 107 & 10 \\
2005 & 21.089 & 1.333 & 776 & 436 & 111 & 10 \\
\hline Total & $\mathbf{8 3 . 2 1 8}$ & $\mathbf{5 . 8 7 0}$ & $\mathbf{3 . 4 5 2}$ & $\mathbf{1 . 8 7 2}$ & $\mathbf{4 9 6}$ & $\mathbf{5 0}$ \\
\hline
\end{tabular}

Buscou-se harmonizar as variáveis entre os diferentes anos e, quando se toma o período mais longo de análise (1997 a 2005), o número de variáveis diminui relativamente à análise com o painel mais curto (1999 a 2005), uma vez que neste há maior proximidade entre os questionários de alunos, professores, diretores, escolas e turmas. Por exemplo, no ano de 1997 não há um questionário específico para as turmas, o que inviabilizou conseguir variáveis passíveis de comparação com as dos demais anos, que descrevessem a quantidade de alunos presentes na sala, a quantidade de horas de aula por dia, se a turma ficou sem professor de matemática por algum período (mais de um mês) e se a turma teve mais de um professor de matemática no período.

As variáveis que entraram na análise e suas respectivas médias e desvios padrões, para amostra do SAEB como um todo e para a amostra do painel 1997-2005, estão descritas nas Tabelas 5, 6, 7, 8 e 9 para alunos, professores, diretores, turmas e escolas, respectivamente. Estas estatísticas descritivas do banco estão separadas pelo tipo de administração da escola, se

\footnotetext{
${ }^{8}$ Para se ter uma idéia do indício de erro nos dados, quase $13 \%$ das escolas que apresentavam dados sobre o desempenho dos alunos de $4^{\mathrm{a}}$ série no SAEB apresentavam, no Censo Escolar, número de matrículas igual a zero. Ao cortar o banco e ficarmos apenas com as escolas cujo número de matrículas é maior ou igual a dez, foram excluídas do banco $17,79 \%$ de escolas que apareciam pelo menos uma vez no período 1997-2005. Isto reduziu bastante a amostra, por outro lado se mostrou imprescindível, caso contrário poderia comprometer os resultados das estimações.
} 
privada ou pública (escolas estaduais e municipais). No Apêndice 2 encontram-se as tabelas com as variáveis descritivas da amostra SAEB e do painel 1997-2005 ano a ano (Tabelas A1, A2, A3, A4 e A5).

Tabela 5-Variáveis de alunos

\begin{tabular}{|c|c|c|c|c|}
\hline Variáveis de alunos & $\begin{array}{l}\text { Amostra SAEB } \\
\text { Escolas Privadas }\end{array}$ & $\begin{array}{l}\text { Painel } 1997-2005 \\
\text { Escolas privadas }\end{array}$ & $\begin{array}{l}\text { Amostra SAEB } \\
\text { Escolas Públicas }\end{array}$ & $\begin{array}{l}\text { Painel 1997-2005 } \\
\text { Escolas Públicas }\end{array}$ \\
\hline Proficiência Média & 219,44 & 223,71 & 172,84 & 171,97 \\
\hline Homens & $51 \%$ & $50,78 \%$ & $50,37 \%$ & $50,39 \%$ \\
\hline Idade 9 anos & $17,70 \%$ & $17,83 \%$ & $9,11 \%$ & $9,77 \%$ \\
\hline Idade 10 anos & $61,83 \%$ & $63,65 \%$ & $37,36 \%$ & $38,26 \%$ \\
\hline Idade 11 anos & $15,04 \%$ & $14,16 \%$ & $22,51 \%$ & $22,28 \%$ \\
\hline Idade 12 ou mais & $5,44 \%$ & $4,35 \%$ & $30,93 \%$ & $29,63 \%$ \\
\hline Branco & $50,89 \%$ & $52,13 \%$ & $36,51 \%$ & $37,03 \%$ \\
\hline Pardo/ Mulato & $35,23 \%$ & $34,40 \%$ & $41,40 \%$ & $40,78 \%$ \\
\hline Negro & $4,75 \%$ & $4,08 \%$ & $12,57 \%$ & $12,30 \%$ \\
\hline Amarelo/Ind. & $7,82 \%$ & $7,95 \%$ & $7,00 \%$ & $7,15 \%$ \\
\hline Mãe do aluno: & & & & \\
\hline Nunca estudou & $1,15 \%$ & $0,94 \%$ & $7,55 \%$ & $7,41 \%$ \\
\hline $1^{\mathrm{a}}$ à $4^{\mathrm{a}} \mathrm{EF}$ & $6,47 \%$ & $5,30 \%$ & $29,10 \%$ & $28,21 \%$ \\
\hline $5^{\mathrm{a}}$ à $8^{\mathrm{a}} \mathrm{EF}$ & $8,98 \%$ & $8,03 \%$ & $18,63 \%$ & $18,87 \%$ \\
\hline Ensino médio & $20,26 \%$ & $19,53 \%$ & $13,20 \%$ & $13,74 \%$ \\
\hline Faculdade & $34,79 \%$ & $38,38 \%$ & $6,56 \%$ & $7,06 \%$ \\
\hline Aluno não sabe & $30,40 \%$ & $30,02 \%$ & $28,27 \%$ & $28,48 \%$ \\
\hline Tem computador & $48,46 \%$ & $53,26 \%$ & $10,08 \%$ & $10,51 \%$ \\
\hline Mora com o pai e mãe & $74,18 \%$ & $75,10 \%$ & $66,02 \%$ & $64,51 \%$ \\
\hline Trabalha fora & $6,77 \%$ & $5,84 \%$ & $18,54 \%$ & $17,12 \%$ \\
\hline Observações & 52.783 & 29.856 & 129.284 & 53.362 \\
\hline
\end{tabular}

Fonte: Cálculos próprios a partir do SAEB (INEP/ MEC). Notas: em 2005 trata-se de computador com Internet; Desvios padrões em parênteses.

Tabela 6-Variáveis de professores

\begin{tabular}{|c|c|c|c|c|}
\hline Variáveis de professores & $\begin{array}{l}\text { Amostra SAEB } \\
\text { Escolas } \\
\text { Privadas }\end{array}$ & $\begin{array}{l}\text { Painel } 1997- \\
2005 \\
\text { Escolas privadas }\end{array}$ & $\begin{array}{l}\text { Amostra SAEB } \\
\text { Escolas } \\
\text { Públicas }\end{array}$ & $\begin{array}{l}\text { Painel 1997- } \\
2005 \\
\text { Escolas Públicas }\end{array}$ \\
\hline Homem & $5,17 \%$ & $4,68 \%$ & $9,44 \%$ & $9,26 \%$ \\
\hline Branco & $54,94 \%$ & $56,94 \%$ & $45,38 \%$ & $45,45 \%$ \\
\hline Pardo/ Mulato & $34,66 \%$ & $33,42 \%$ & $42,96 \%$ & $4380 \%$ \\
\hline Negro & $5,00 \%$ & $4,40 \%$ & $6,38 \%$ & $6,31 \%$ \\
\hline Amarelo/ Ind. & $3,75 \%$ & $3,85 \%$ & $3,57 \%$ & $3,16 \%$ \\
\hline Idade: & & & & \\
\hline Até 30 anos (a) & $27,47 \%$ & $24,22 \%$ & $21,36 \%$ & $20,12 \%$ \\
\hline De 30 a 40 anos (b) & $39,19 \%$ & $41,08 \%$ & $34,85 \%$ & $34,76 \%$ \\
\hline 40 ou mais anos (c) & $29,82 \%$ & $30,94 \%$ & $38,70 \%$ & $40,12 \%$ \\
\hline Escolaridade: & & & & \\
\hline Até o ensino médio & $33,48 \%$ & $29,33 \%$ & $46,88 \%$ & $46,09 \%$ \\
\hline Ensino superior (outro) & $61,34 \%$ & $65,33 \%$ & $46,94 \%$ & $47,80 \%$ \\
\hline Leciona há até 15 anos (d) & $60,03 \%$ & $56,02 \%$ & $55,78 \%$ & $54,87 \%$ \\
\hline Leciona há mais de 15 anos (e) & $36,10 \%$ & 39,75 & $38,69 \%$ & $39,85 \%$ \\
\hline $\begin{array}{l}\text { Participou de curso } \\
\text { de capacitação nos últimos } 2 \text { anos } \\
\text { (f) }\end{array}$ & $82,74 \%$ & $84,39 \%$ & $78,50 \%$ & $78,45 \%$ \\
\hline
\end{tabular}

(a) 1997 e 1999 incluem 30 anos; (b) 1997 e 1999 incluem 40 anos; (c) 1997 e 1999 a partir de 41 anos; (d) 2001 há até 14 anos; (e) 2001 há mais de 14 anos;(f) para 1997: no próprio ano. 
Tabela 7-Variáveis de diretores

\begin{tabular}{lcccc}
\hline Variáveis de diretores & $\begin{array}{c}\text { Amostra SAEB } \\
\text { Escolas Privadas }\end{array}$ & $\begin{array}{c}\text { Painel 1997-2005 } \\
\text { Escolas privadas }\end{array}$ & $\begin{array}{c}\text { Amostra SAEB } \\
\text { Escolas Públicas }\end{array}$ & $\begin{array}{c}\text { Painel 1997-2005 } \\
\text { Escolas Públicas }\end{array}$ \\
\hline Exerce a função de diretor há: & & & & $53,17 \%$ \\
Menos de 5 anos & $21,24 \%$ & $20,26 \%$ & $54,72 \%$ \\
Entre 5 e 10 anos & $26,68 \%$ & $25,15 \%$ & $29,89 \%$ & $29,11 \%$ \\
Mais de 10 anos & $50,08 \%$ & $52,76 \%$ & $14,49 \%$ & $14,34 \%$ \\
É diretor desta escola há: & $35,65 \%$ & $35,60 \%$ & $68,52 \%$ & $70,62 \%$ \\
Menos de 5 anos & $27,94 \%$ & $27,98 \%$ & $22,31 \%$ & $21,00 \%$ \\
Entre 5 e 10 anos & $34,29 \%$ & $34,43 \%$ & $6,88 \%$ & $6,87 \%$ \\
Mais de 10 anos & & & & $50,38 \%$ \\
Assumiu o cargo por: & $60,41 \%$ & $60,35 \%$ & $51,68 \%$ & $47,39 \%$ \\
Exame de seleção e / ou eleição & $22,5 \%$ & $23,72 \%$ & $45,09 \%$ & $18,98 \%$ \\
Indicação ou outras formas & & & & $65,46 \%$ \\
Projeto pedagógico: & $9,24 \%$ & $8,52 \%$ & $19,75 \%$ & $11,21 \%$ \\
Secretaria da Educação & $82,70 \%$ & $83,44 \%$ & $64,16 \%$ & $28,37 \%$ \\
Diretor e Professores & $3,36 \%$ & $2,90 \%$ & $11,33 \%$ & $24,55 \%$ \\
Não houve no ano & $11,16 \%$ & $10,28 \%$ & $28,29 \%$ & $22,56 \%$ \\
Alta rotatividade de professores & $6,69 \%$ & $6,47 \%$ & & $5 \%$ \\
Professores faltosos & & & & \\
\hline
\end{tabular}

Fonte: Cálculos próprios a partir do SAEB (INEP/ MEC)

Tabela 8-Variáveis de turmas

\begin{tabular}{|c|c|c|c|c|}
\hline Variáveis de turmas & $\begin{array}{l}\text { Amostra } \\
\text { SAEB } \\
\text { Escolas } \\
\text { Privadas }\end{array}$ & $\begin{array}{l}\text { Painel } \\
1997- \\
2005 \\
\text { Escolas } \\
\text { privadas }\end{array}$ & $\begin{array}{l}\text { Amostra } \\
\text { SAEB } \\
\text { Escolas } \\
\text { Públicas }\end{array}$ & $\begin{array}{l}\text { Painel } \\
1997- \\
2005 \\
\text { Escolas } \\
\text { Públicas }\end{array}$ \\
\hline Não teve professor de matemática no ano & $3,78 \%$ & $3,91 \%$ & $4,35 \%$ & $4,29 \%$ \\
\hline Teve apenas um professor de matemática & $88,37 \%$ & $89,36 \%$ & $78,95 \%$ & $77,75 \%$ \\
\hline Teve dois ou mais professores de matemática & $7,84 \%$ & $6,72 \%$ & $16,70 \%$ & $17,95 \%$ \\
\hline Ficou nenhum mês sem professor de matemática & 90,96 & $98,30 \%$ & $95,69 \%$ & $95,26 \%$ \\
\hline $\begin{array}{l}\text { Ficaram pelo menos um mês sem professor de matemática } \\
\text { Turno: }\end{array}$ & $1,99 \%$ & $1,70 \%$ & $4,25 \%$ & $4,74 \%$ \\
\hline Até 4 horas de aula por dia & $38,61 \%$ & $34,02 \%$ & $56,69 \%$ & $55,31 \%$ \\
\hline Entre 4 e 5 horas de aula por dia & $59,38 \%$ & $64,20 \%$ & $39,11 \%$ & $40,91 \%$ \\
\hline Mais de 5 horas de aula por dia & $2,01 \%$ & $1,77 \%$ & $4,19 \%$ & $3,78 \%$ \\
\hline Número médio das turmas & $\begin{array}{l}25,77 \\
(9,19)\end{array}$ & $\begin{array}{l}27,53 \\
(8,38)\end{array}$ & $\begin{array}{l}30,63 \\
(7,96)\end{array}$ & $\begin{array}{l}31,28 \\
(7,87)\end{array}$ \\
\hline \multicolumn{5}{|l|}{ Tamanho da turma: } \\
\hline Até 10 alunos & $5,41 \%$ & $1,36 \%$ & $0,93 \%$ & $0,38 \%$ \\
\hline De 11 a 19 alunos & $20,41 \%$ & $16,65 \%$ & $6,83 \%$ & $0,05 \%$ \\
\hline De 20 a 29 alunos & $36,73 \%$ & $38,71 \%$ & $34,56 \%$ & $34,08 \%$ \\
\hline De 30 a 39 alunos & $30,65 \%$ & $35,53 \%$ & $44,55 \%$ & $45,34 \%$ \\
\hline Mais de 40 alunos & $6,80 \%$ & $7,75 \%$ & $13,12 \%$ & $14,91 \%$ \\
\hline
\end{tabular}

Fonte: Cálculos próprios a partir do SAEB e Censo Escolar (INEP/MEC).

Notas: Não há questionário de Turmas no SAEB para o ano 1997; Desvios padrões em parênteses. 
Tabela 9-Variáveis de escolas

\begin{tabular}{|c|c|c|c|c|}
\hline Variáveis de escolas & $\begin{array}{l}\text { Amostra SAEB } \\
\text { Escolas } \\
\text { Privadas }\end{array}$ & $\begin{array}{l}\text { Painel } \\
1997-2005 \\
\text { Escolas } \\
\text { privadas }\end{array}$ & $\begin{array}{l}\text { Amostra SAEB } \\
\text { Escolas } \\
\text { Públicas }\end{array}$ & $\begin{array}{l}\text { Painel } \\
\text { 1997-2005 } \\
\text { Escolas } \\
\text { Públicas }\end{array}$ \\
\hline $\begin{array}{l}\text { Localização da escola na região rural } \\
\text { Departamento administrativo: }\end{array}$ & $1,07 \%$ & $0,86 \%$ & $16,23 \%$ & $8,60 \%$ \\
\hline Estadual & - & - & $46,65 \%$ & $52,03 \%$ \\
\hline Municipal & - & - & $53,34 \%$ & $47,96 \%$ \\
\hline Particular & $100 \%$ & $100 \%$ & & \\
\hline Biblioteca & $86,29 \%$ & $91,28 \%$ & $51,77 \%$ & $56,88 \%$ \\
\hline Laboratórios: & & & & \\
\hline De Informática & $70,11 \%$ & $79,57 \%$ & $17,42 \%$ & $20,59 \%$ \\
\hline De Ciências & $52,91 \%$ & $62,12 \%$ & $10,84 \%$ & $13,30 \%$ \\
\hline Quadra de esportes & $77,44 \%$ & $86,25 \%$ & $46,10 \%$ & $52,17 \%$ \\
\hline Internet (a) & $57,60 \%$ & $66,40 \%$ & $22,62 \%$ & $22,70 \%$ \\
\hline Microcomputadores para fins (a): & & & & \\
\hline Pedagógicos & $70,21 \%$ & $77,21 \%$ & $25,64 \%$ & $28,60 \%$ \\
\hline Administrativos & $77,41 \%$ & $83,30 \%$ & $55,30 \%$ & $61,28 \%$ \\
\hline Uso em sala de aula & $9,21 \%$ & $10,57 \%$ & $0,89 \%$ & $1,02 \%$ \\
\hline Programas sociais: & & & & \\
\hline Comunidade Solidária (b) & $1,11 \%$ & $1,50 \%$ & $3,68 \%$ & $3,62 \%$ \\
\hline FNDE (c) & $1,30 \%$ & $1,04 \%$ & $76,46 \%$ & $82,43 \%$ \\
\hline Transporte Escolar & $2,07 \%$ & $2,01 \%$ & $18,66 \%$ & $21,14 \%$ \\
\hline TV Escola (MEC) & $3,76 \%$ & $3,12 \%$ & $55,87 \%$ & $60,64 \%$ \\
\hline Informática (a) & $1,71 \%$ & $1,66 \%$ & $13,45 \%$ & $15,38 \%$ \\
\hline Livro didático (c) & $3,35 \%$ & $2,25 \%$ & $78,09 \%$ & $81,83 \%$ \\
\hline Merenda Escolar & $8,90 \%$ & $8,38 \%$ & $96,53 \%$ & $98,84 \%$ \\
\hline Renda Mínima & $3,84 \%$ & $3,67 \%$ & $56,22 \%$ & $54,41 \%$ \\
\hline Professores no ensino fundamental & $\begin{array}{c}28,70 \\
(26,35)\end{array}$ & $\begin{array}{c}34,76 \\
(28,21)\end{array}$ & $\begin{array}{c}25,98 \\
(20,32)\end{array}$ & $\begin{array}{c}28,90 \\
(21,64)\end{array}$ \\
\hline Turmas $4^{\mathrm{a}}$ série período diurno & $\begin{array}{c}1,87 \\
(1,84)\end{array}$ & $\begin{array}{c}2,25 \\
(2,11)\end{array}$ & $\begin{array}{c}2,11 \\
(1,93)\end{array}$ & $\begin{array}{c}2,65 \\
(1,86)\end{array}$ \\
\hline Turmas $4^{\mathrm{a}}$ série período noturno & $\begin{array}{c}0,63 \\
(2,04)\end{array}$ & $\begin{array}{c}0,73 \\
(2,21)\end{array}$ & $\begin{array}{c}0,66 \\
(1,82)\end{array}$ & $\begin{array}{c}0,57 \\
(1,62)\end{array}$ \\
\hline Total Turmas de $4^{a}$ série & $\begin{array}{c}2,49 \\
(2,31)\end{array}$ & $\begin{array}{c}2,99 \\
(2,49)\end{array}$ & $\begin{array}{c}2,77 \\
(2,22)\end{array}$ & $\begin{array}{c}3,22 \\
(1,97)\end{array}$ \\
\hline Matrículas $4^{\mathrm{a}}$ série diurno & $\begin{array}{c}57,83 \\
(62,97)\end{array}$ & $\begin{array}{c}75,14 \\
(70,88)\end{array}$ & $\begin{array}{c}73,71 \\
(69,48)\end{array}$ & $\begin{array}{c}94,30 \\
(68,16)\end{array}$ \\
\hline Matrículas $4^{\mathrm{a}}$ série noturno & $\begin{array}{c}23,01 \\
(71,33)\end{array}$ & $\begin{array}{c}26,34 \\
(75,56)\end{array}$ & $\begin{array}{c}22,90 \\
(66,35)\end{array}$ & $\begin{array}{c}19,64 \\
(59,93)\end{array}$ \\
\hline Total de matrículas na $4^{\mathrm{a}}$ série & $\begin{array}{c}60,37 \\
(65,92)\end{array}$ & $\begin{array}{c}78,12 \\
(73,22)\end{array}$ & $\begin{array}{c}79,21 \\
(73,89)\end{array}$ & $\begin{array}{l}100,46 \\
(71,21)\end{array}$ \\
\hline Total de escolas & 3.399 & 978 & 6.741 & 1.584 \\
\hline
\end{tabular}

Fonte: Cálculos próprios a partir do Censo Escolar (INEP / MEC).Notas: (a) Sem informações para 1997; (b) Sem informações para 1997 e 2005; (c) Sem informações para 2005; Desvios padrões em parênteses. 
Como se pode verificar, comparando-se as colunas da amostra do SAEB como um todo e as colunas com os dados dos painéis, não há problemas de seleção nos bancos utilizados neste trabalho.

\subsection{Metodologia}

No presente trabalho a questão é investigar o quanto algumas características observáveis das escolas e professores podem contribuir para o aprendizado dos alunos. É importante haver professores com elevado grau de instrução ou experiência? A forma com que é selecionado o diretor da escola é importante para a qualidade do ensino? Em geral, os alunos se saem melhor se estudam em turmas grandes, médias ou pequenas? Um dos grandes desafios em trabalhos de economia aplicada envolve responder o que aconteceria se situações diferentes do que foi ou pode ser observado se passasse com a unidade de observação - o chamado "contrafactual". Isto porque observamos apenas se as escolas tem ou não essas características, sem poder observar sua situação se elas tivessem características diferentes.

Esta é a dificuldade em se saber lidar com situações "contrafactuais". Tudo o que se pode observar é o resultado de apenas um dos cenários, para cada unidade de observação. Em muitos campos da ciência, especialmente nas ciências médicas, a visão predominante é de que a melhor evidência sobre contrafactuais é gerada por experimentos aleatórios, pois atribuir de forma aleatória um tratamento garante que os resultados obtidos no grupo de controle realmente capturem o contrafactual para um grupo de tratados (ANGRIST; KRUEGER, 1999, p. 1283). Porém, em economia, para se saber qual seria o resultado sob o estado contrafactual os economistas precisam lançar mão de estratégias de identificação, uma vez que é muito difícil (porém não impossível) realizar estudos com caráter verdadeiramente aleatório 9 .

As estratégias de identificação são entendidas aqui como as estratégias metodológicas que os economistas desenvolveram para mimetizar, em seus estudos "observacionais", as condições de análise de um experimento aleatório para gerarem evidências convincentes sobre os efeitos

\footnotetext{
${ }^{9}$ Como ressalta ANGRIST e KRUEGER (1999, p. 1280-1283), pode-se partir de modelos estruturais para se estudar relações de causalidade. Pesquisas com desenho estrutural tomam fortemente como base a teoria econômica para guiar o trabalho empírico, fazer previsões e afirmações de causalidade. Já os chamados estudos "experimentalistas" ou quase-experimentais realizam análises cujo desenho tenta se aproximar ao máximo ao de um real estudo de experimento aleatório. Nas duas metodologias busca-se estimar as características das relações causais de interesse. Enquanto os modelos estruturais geralmente incorporam algumas hipóteses sobre variabilidade exógena em algumas variáveis, as análises quase-experimentais requerem algumas hipóteses teóricas.
} 
de causalidade que querem investigar. Essas estratégias compreendem o controle por diferenças observáveis entre os grupos de comparação usando técnicas de regressão ou "matching", comparações das mesmas unidades de observação em dois períodos do tempo para reduzir o viés de diferenças não-observáveis e também o uso de "variáveis instrumentais" como fonte de variação quase-experimental. Testes realizados com o uso de aleatoriedade na designação dos grupos de tratamento e controle formam o paradigma conceitual para julgar o fracasso ou sucesso no desenho destes experimentos observacionais, mesmo que seja impossível estudar algumas questões com o uso de designações aleatórias. Na maioria dos casos, costuma-se indagar se o formato da pesquisa é um bom "experimento natural" ou não.

A estratégia de identificação que se utilizará no presente estudo é explorar os dados em painel que permitem o controle por efeitos específicos não observados das escolas. Pretende-se examinar o efeito que uma série de insumos escolares (variáveis causais) exercem sobre o aprendizado. É coerente supor que existam características não-observáveis das escolas que também influenciam o aprendizado e que podem estar correlacionadas com os insumos escolares cujos efeitos pretende-se captar. Na literatura sobre o tema, é sabido que as características socioeconômicas dos alunos contribuem fortemente para explicar o desempenho. Por isso estas serão também incluídas nas análises como variáveis de controle ${ }^{10}$. No Apêndice 2 encontra-se a descrição da metodologia de estimação com dados em painel e efeitos específicos não-observáveis

As metodologias de Mínimos Quadrados agrupados, Efeitos Fixos e Efeitos Aleatórios foram exploradas neste trabalho para se estimar a seguinte equação que modela o desempenho dos alunos na prova de matemática do SAEB:

$$
Y_{i j t}=\alpha_{0}+A_{i j t} \beta_{1}+P_{i j t} \beta_{2}+D_{i j t} \beta_{3}+T_{i j t} \beta_{4}+E_{i j t} \beta_{5}+c_{j}+u_{i j t}
$$

Em que:

$Y_{i j t}$ é a nota do aluno i na escola $\mathrm{j}$ no tempo $\mathrm{t}$

\footnotetext{
${ }^{10}$ É importante atentar para a distinção entre variáveis causais e variáveis de controle. A estratégia de identificação consiste na combinação de uma fonte de variação na variável que se quer analisar o efeito causal e o uso de técnicas econométricas para explorar esta informação, mantendo tudo o mais constante. Isto é, variáveis de controle são muitas vezes incluídas nas regressões para que os seus efeitos não se confundam com os efeitos da variável causal, que são o objeto de interesse primordial.
} 
$\alpha_{0}$ é uma constante

$A_{i j t}$ vetor de características do aluno i na escola $\mathrm{j}$ no tempo $\mathrm{t}$

$P_{i j t}$ vetor de características do professor de matemática do aluno i na escola $\mathrm{j}$ no tempo $\mathrm{t}$

$D_{i j t}$ vetor de características do diretor do aluno i na escola j no tempo $\mathrm{t}$

$T_{i j t}$ vetor de características da turma do aluno i na escola $\mathrm{j}$ no tempo $\mathrm{t}$

$E_{i j t}$ vetor de características de infra-estrutura da escola do aluno i no tempo $\mathrm{t}$

$c_{j}$ efeito específico não-observado da escola

$u_{i j t}$ erro idiossincrático

O vetor de parâmetros de interesse é $\boldsymbol{\beta}$, tal que $\boldsymbol{\beta}{ }^{\prime}=\left(\beta_{1}{ }_{1} \beta_{2}{ }_{2} \beta_{3}{ }_{3} \beta_{4}{ }_{4} \beta{ }_{5}\right)$ reporta as relações condicionais dos insumos escolares sobre o desempenho dos alunos. A equação (2.1) é a função de produção de educação, como conhecida na literatura.

\subsection{Resultados}

Na tabela 10, 11, encontram-se os resultados das estimações realizadas por MQO agrupados e Efeitos Fixos (EF) da equação (2.1) utilizando-se o painel de escolas mais longo para escolas públicas e privadas, respectivamente. Nas estimações de MQO agrupados utilizou-se as observações de cada aluno na regressão (primeira coluna de resultados), enquanto as estimações de Efeitos Fixos de escola foram feitas tanto com observações de cada aluno (segunda coluna de resultados) quanto com as variáveis na média por escola (terceira coluna de resultados). As estimações de MQO foram reportadas para serem comparadas com as obtidas por EF. Porém, como mencionado na seção anterior, o método de MQO agrupados é enviesado na presença de variável omitida que esteja correlacionada com o erro. As estimações por Efeitos Aleatórios não foram reportadas, pois na maioria dos casos os resultados do teste de Hausman levaram a que se rejeitasse a hipótese de que o modelo de Efeitos Aleatórios é o mais adequado ${ }^{11}$.

\footnotetext{
${ }^{11}$ Os resultados dos testes de Hausman são reportados nas últimas linhas das Tabelas de 10 à 13.
} 
Tabela 10-Proficiência em matemática $4^{\text {a }}$ série - escolas públicas (painel 1997, 1999, 2001, 2003 e 2005)

\begin{tabular}{|c|c|c|c|}
\hline Variáveis & $\begin{array}{l}\text { MQO agrupados } \\
\text { (dados de indivíduos) }\end{array}$ & $\begin{array}{l}\text { Efeitos Fixos } \\
\text { (dados de indivíduos) }\end{array}$ & $\begin{array}{l}\text { Efeitos Fixos } \\
\text { (dados de escola) }\end{array}$ \\
\hline \multicolumn{4}{|l|}{ Alunos } \\
\hline Homem & $\begin{array}{l}4,989 * * * \\
(0,366)\end{array}$ & $\begin{array}{l}4,647 * * * \\
(0,358)\end{array}$ & $\begin{array}{l}-0,873 \\
(2,329)\end{array}$ \\
\hline 9 anos & Base & Base & Base \\
\hline 10 anos & $\begin{array}{l}1,313 * \\
(0,692)\end{array}$ & $\begin{array}{l}-0,341 \\
(0,658)\end{array}$ & $\begin{array}{l}11,909 * * * \\
(3,902)\end{array}$ \\
\hline 11 anos & $\begin{array}{l}-9,988 * * * \\
(0,728)\end{array}$ & $\begin{array}{l}-9,149 * * * \\
(0,715)\end{array}$ & $\begin{array}{l}4,060 \\
(4,287)\end{array}$ \\
\hline 12 ou mais & $\begin{array}{l}-15,740 * * * \\
(0,708)\end{array}$ & $\begin{array}{l}-14,299 * * * \\
(0,724)\end{array}$ & $\begin{array}{l}-1,682 \\
(3,790)\end{array}$ \\
\hline Computador & $\begin{array}{l}6,200 * * * \\
(0,695)\end{array}$ & $\begin{array}{l}-1,032 \\
(0,713)\end{array}$ & $\begin{array}{l}-8,556^{* *} \\
(4,133)\end{array}$ \\
\hline Branco & Base & Base & Base \\
\hline Pardo /mulato & $\begin{array}{l}-0,397 \\
(0,414)\end{array}$ & $\begin{array}{l}2,380 * * * \\
(0,435)\end{array}$ & $\begin{array}{l}4,113^{*} \\
(2,170)\end{array}$ \\
\hline Negro & $\begin{array}{l}-10,694 * * * \\
(0,564)\end{array}$ & $\begin{array}{l}-6,558^{* * *} \\
(0,594)\end{array}$ & $\begin{array}{l}0,334 \\
(3,482)\end{array}$ \\
\hline Amarelo /índio & $\begin{array}{l}-0,535 \\
(0,762)\end{array}$ & $\begin{array}{l}1,424 * * \\
(0,717)\end{array}$ & $\begin{array}{l}5,897 \\
(4,254)\end{array}$ \\
\hline Mora pai e mãe & $\begin{array}{l}2,091 * * * \\
(0,378)\end{array}$ & $\begin{array}{l}0,858 * * \\
(0380)\end{array}$ & $\begin{array}{l}3,471 \\
(2,276)\end{array}$ \\
\hline Estudo da mãe: & & & \\
\hline Nunca estudou & Base & Base & Base \\
\hline 1à $4^{\mathrm{a}}$ série & $\begin{array}{l}4,207 * * * \\
(0,731)\end{array}$ & $\begin{array}{l}2,666 * * * \\
(0,739)\end{array}$ & $\begin{array}{l}-5,316 \\
(3,560)\end{array}$ \\
\hline $5^{\mathrm{a}}$ à $8^{\mathrm{a}}$ série & $\begin{array}{l}6,502 * * * \\
(0,779)\end{array}$ & $\begin{array}{l}4,505^{* * * *} \\
(0,800)\end{array}$ & $\begin{array}{l}-12,308 * * * \\
(4,046)\end{array}$ \\
\hline Ensino médio & $\begin{array}{l}13,388 * * * \\
(0,860)\end{array}$ & $\begin{array}{l}9,652 * * * \\
(0,888)\end{array}$ & $\begin{array}{l}-3,939 \\
(4,708)\end{array}$ \\
\hline Faculdade & $\begin{array}{l}11,307 * * * \\
(1,016)\end{array}$ & $\begin{array}{l}6,109 * * * \\
(1,070)\end{array}$ & $\begin{array}{l}-4,780 \\
(5,917)\end{array}$ \\
\hline Aluno não sabe & $\begin{array}{l}6,008 * * * \\
(0,753)\end{array}$ & $\begin{array}{l}3,618 * * * \\
(0,792)\end{array}$ & $\begin{array}{l}-13,118 * * * \\
(3,503)\end{array}$ \\
\hline Professores & & & \\
\hline Homem & $\begin{array}{l}-3,083 * * * \\
(0,610)\end{array}$ & $\begin{array}{l}0,681 \\
(1,266)\end{array}$ & $\begin{array}{l}1,598 \\
(1,371)\end{array}$ \\
\hline Até 29 anos & Base & Base & Base \\
\hline 30 a 40 anos & $\begin{array}{l}0,575 \\
(0,505)\end{array}$ & $\begin{array}{l}0,831 \\
(1,079)\end{array}$ & $\begin{array}{l}1,103 \\
(1,072)\end{array}$ \\
\hline 40 ou mais & $\begin{array}{l}1,369 * * \\
(0,588)\end{array}$ & $\begin{array}{l}1,271 \\
(1,188)\end{array}$ & $\begin{array}{l}1,892 \\
(1,328)\end{array}$ \\
\hline Tem ensino superior & $\begin{array}{l}3,754 * * * \\
(0,393)\end{array}$ & $\begin{array}{l}-0,200 \\
(0,795)\end{array}$ & $\begin{array}{l}0,095 \\
(0,928)\end{array}$ \\
\hline Fez curso capacitação & $\begin{array}{l}-0,197 \\
(0,476)\end{array}$ & $\begin{array}{l}0,543 \\
(0,900)\end{array}$ & $\begin{array}{l}-0,739 \\
(0,993)\end{array}$ \\
\hline Leciona há mais de 15 anos & $\begin{array}{l}-0,742 \\
(0,474)\end{array}$ & $\begin{array}{l}-0,627 \\
(0,948)\end{array}$ & $\begin{array}{l}0,397 \\
(1,088)\end{array}$ \\
\hline Diretores & & & \\
\hline Exerce função há menos de 5 anos & Base & Base & Base \\
\hline Exerce função entre 5 e 10 anos & $\begin{array}{l}-0,903 \\
(0,568)\end{array}$ & $\begin{array}{l}-0,589 \\
(1,273)\end{array}$ & $\begin{array}{l}-1,641 \\
(1,228)\end{array}$ \\
\hline Exerce função há mais de 10 anos & $\begin{array}{l}0,766 \\
(0,786)\end{array}$ & $\begin{array}{l}1,382 \\
(2,276)\end{array}$ & $\begin{array}{l}1,116 \\
(1,894)\end{array}$ \\
\hline $\begin{array}{l}\text { Direção da escola há menos de } 5 \\
\text { anos }\end{array}$ & Base & Base & Base \\
\hline
\end{tabular}




\begin{tabular}{|c|c|c|c|}
\hline Variáveis & $\begin{array}{l}\text { MQO agrupados } \\
\text { (dados de indivíduos) }\end{array}$ & $\begin{array}{l}\text { Efeitos Fixos } \\
\text { (dados de indivíduos) }\end{array}$ & $\begin{array}{l}\text { Efeitos Fixos } \\
\text { (dados de escola) }\end{array}$ \\
\hline Direção da escola entre 5 e 10 anos & $\begin{array}{l}1,079^{*} \\
(0,623)\end{array}$ & $\begin{array}{l}0,092 \\
(1,550)\end{array}$ & $\begin{array}{l}0,531 \\
(1,386)\end{array}$ \\
\hline $\begin{array}{l}\text { Direção da escola há mais de } 10 \\
\text { anos }\end{array}$ & $\begin{array}{l}3,404 * * * \\
(1,008)\end{array}$ & $\begin{array}{l}0,700 \\
(3,741)\end{array}$ & $\begin{array}{l}-1,326 \\
(2,685)\end{array}$ \\
\hline Problema com professores faltosos & $\begin{array}{l}-1,081 * * \\
(0,437)\end{array}$ & $\begin{array}{l}-0,227 \\
(0,902)\end{array}$ & $\begin{array}{l}0,389 \\
(1,013)\end{array}$ \\
\hline $\begin{array}{l}\text { Assumiu o cargo por concurso } \\
\text { público, seleção, eleição. }\end{array}$ & Base & Base & Base \\
\hline $\begin{array}{l}\text { Assumiu cargo por indicação, } \\
\text { outras formas }\end{array}$ & $\begin{array}{l}-2,160 * * * \\
(0,376)\end{array}$ & $\begin{array}{l}0,827 \\
(1,138)\end{array}$ & $\begin{array}{l}0,920 \\
(1,068)\end{array}$ \\
\hline $\begin{array}{l}\text { Projeto Pedagógico elaborado pela } \\
\text { Secretariada Educação }\end{array}$ & Base & Base & Base \\
\hline $\begin{array}{l}\text { Projeto Pedagógico elaborado pelo } \\
\text { diretor e professores }\end{array}$ & $\begin{array}{l}1,939 * * * \\
(0,456)\end{array}$ & $\begin{array}{l}0,745 \\
(0,898)\end{array}$ & $\begin{array}{l}-0,391 \\
(0,970)\end{array}$ \\
\hline $\begin{array}{l}\text { Não houve Projeto Pedagógico no } \\
\text { ano } \\
\text { Escola }\end{array}$ & $\begin{array}{l}-1,916^{* * *} \\
(0,649)\end{array}$ & $\begin{array}{l}0,499 \\
(1,285)\end{array}$ & $\begin{array}{l}-0,112 \\
(1,383)\end{array}$ \\
\hline Região rural & $\begin{array}{l}-3,582 * * * \\
(0,682)\end{array}$ & - & - \\
\hline Administração municipal & $\begin{array}{l}-1,441 * * * \\
(0,394)\end{array}$ & - & - \\
\hline Biblioteca & $\begin{array}{l}1,882 * * * \\
(0,422)\end{array}$ & $\begin{array}{l}-1,823 \\
(1,127)\end{array}$ & $\begin{array}{l}-2,340 * * \\
(1,123)\end{array}$ \\
\hline Laboratório de informática & $\begin{array}{l}1,423 * * * \\
(0,544)\end{array}$ & $\begin{array}{l}1,115 \\
(1,196)\end{array}$ & $\begin{array}{l}2,096 \\
(1,409)\end{array}$ \\
\hline Laboratório de ciências & $\begin{array}{l}7,830 * * * \\
(0,649)\end{array}$ & $\begin{array}{l}2,008 \\
(2,192)\end{array}$ & $\begin{array}{l}0,518 \\
(1,878)\end{array}$ \\
\hline Quadra de esportes & $\begin{array}{l}2,164 * * * \\
(0,420)\end{array}$ & $\begin{array}{l}0,216 \\
(1,240)\end{array}$ & $\begin{array}{l}0,940 \\
(1,314)\end{array}$ \\
\hline Programa TV na escola & $\begin{array}{l}0,405 \\
(0,390)\end{array}$ & $\begin{array}{l}-1,813^{*} \\
(0,943)\end{array}$ & $\begin{array}{l}-1,187 \\
(0,974)\end{array}$ \\
\hline Merenda & $\begin{array}{l}4,334 * * \\
(1,782)\end{array}$ & $\begin{array}{l}0,212 \\
(3,173)\end{array}$ & $\begin{array}{l}1,234 \\
(3,153)\end{array}$ \\
\hline Professores no EF & $\begin{array}{l}-0,008 \\
(0,013)\end{array}$ & $\begin{array}{l}0,068 \\
(0,048)\end{array}$ & $\begin{array}{l}0,082 \\
(0,056)\end{array}$ \\
\hline Turmas na $4^{\mathrm{a}}$ série diurnas & $\begin{array}{l}0,700 * * * \\
(0,222)\end{array}$ & $\begin{array}{l}-0,086 \\
(0,487)\end{array}$ & $\begin{array}{l}0,326 \\
(0,558)\end{array}$ \\
\hline Turmas na $4^{\mathrm{a}}$ série noturnas & $\begin{array}{l}-0,240 \\
(0,386)\end{array}$ & $\begin{array}{l}-0,978 \\
(1,067)\end{array}$ & $\begin{array}{l}0,992 \\
(1,040)\end{array}$ \\
\hline Matrículas na $4^{\mathrm{a}}$ série & $\begin{array}{l}-0,030^{* * * *} \\
(0,006)\end{array}$ & $\begin{array}{l}-0,013 \\
(0,012)\end{array}$ & $\begin{array}{l}-0,033 * * * \\
(0,013)\end{array}$ \\
\hline D_1997 & Base & Base & Base \\
\hline D_1999 & $\begin{array}{l}-5,859 * * * \\
(1,782)\end{array}$ & $\begin{array}{l}-9,295^{* *} \\
(3,637)\end{array}$ & $\begin{array}{l}-3,514 \\
(4,207)\end{array}$ \\
\hline D_2001 & $\begin{array}{l}-10,515^{* * *} \\
(1,803)\end{array}$ & $\begin{array}{l}-14,359 * * * \\
(3,742)\end{array}$ & $\begin{array}{l}-11,488 * * * \\
(4,366)\end{array}$ \\
\hline D_2003 & $\begin{array}{l}-11,363 * * * \\
(1,825)\end{array}$ & $\begin{array}{l}-16,231^{* * * *} \\
(3,793)\end{array}$ & $\begin{array}{l}-11,836^{* * * *} \\
(4,444)\end{array}$ \\
\hline D_2005 & $\begin{array}{l}-9,077^{* * * *} \\
(1,845)\end{array}$ & $\begin{array}{l}-11,713^{* * * *} \\
(3,827)\end{array}$ & $\begin{array}{l}-7,837^{*} \\
(4,490)\end{array}$ \\
\hline Constante & $\begin{array}{l}171,879 * * * \\
(2,717)\end{array}$ & $\begin{array}{l}184,689 * * * \\
(4,876)\end{array}$ & $\begin{array}{l}178,618^{* * *} \\
(7,498)\end{array}$ \\
\hline Observações & 40.801 & 40.801 & 3.204 \\
\hline Grupos & & 1.577 & 1.577 \\
\hline R2 Within & & 0,0462 & 0,1046 \\
\hline R2 Between & & 0,2292 & 0,0114 \\
\hline R2 Total & 0,1148 & 0,0802 & 0,0401 \\
\hline
\end{tabular}




\begin{tabular}{|c|c|c|c|}
\hline Variáveis & $\begin{array}{l}\text { MQO agrupados } \\
\text { (dados de indivíduos) }\end{array}$ & $\begin{array}{l}\text { Efeitos Fixos } \\
\text { (dados de indivíduos) }\end{array}$ & $\begin{array}{l}\text { Efeitos Fixos } \\
\text { (dados de escola) }\end{array}$ \\
\hline Hausman & & - & $\begin{array}{l}\text { Chi } 2(42)=308,31 \\
\text { Prob }>\text { chi } 2=0,000\end{array}$ \\
\hline
\end{tabular}

Notas: (a) Desvios padrões ajustados para 1.577 "clusters" de escola.

Graus de significância: * 10\%; ** 5\%,***1\%.

Tabela 11- Proficiência em matemática $4^{a}$ série - escolas privadas (painel 1997, 1999, 2001, 2003 e 2005)

\begin{tabular}{|c|c|c|c|}
\hline Variáveis & $\begin{array}{l}\text { MQO agrupados } \\
\text { (dados de indivíduos) }\end{array}$ & $\begin{array}{l}\text { Efeitos Fixos } \\
\text { (dados de indivíduos) }\end{array}$ & $\begin{array}{l}\text { Efeitos Fixos } \\
\text { (dados de escola) }\end{array}$ \\
\hline Homem & $\begin{array}{l}6,021 * * * \\
(0,546)\end{array}$ & $\begin{array}{l}6,457 * * * \\
(0,539)\end{array}$ & $\begin{array}{l}8,612 * * * \\
(2,691)\end{array}$ \\
\hline 9 anos & Base & Base & Base \\
\hline 10 anos & $\begin{array}{l}4,003 * * * \\
(0,733)\end{array}$ & $\begin{array}{l}0,302 \\
(0,756)\end{array}$ & $\begin{array}{l}-0,166 \\
(3,346)\end{array}$ \\
\hline 11 anos & $\begin{array}{l}-5,062 * * * \\
(1,025)\end{array}$ & $\begin{array}{l}-9,241 * * * \\
(1,123)\end{array}$ & $\begin{array}{l}-14,931 * * * \\
(4,749)\end{array}$ \\
\hline 12 ou mais & $\begin{array}{l}-27,787 * * * \\
(1,538)\end{array}$ & $\begin{array}{l}-25,747 * * * \\
(1,794)\end{array}$ & $\begin{array}{l}-28,819 * * * \\
(6,602)\end{array}$ \\
\hline Computador & $\begin{array}{l}9,236 * * * \\
(0,619)\end{array}$ & $\begin{array}{l}1,252^{*} \\
(0,645)\end{array}$ & $\begin{array}{l}2,890 \\
(2,914)\end{array}$ \\
\hline Branco & Base & Base & Base \\
\hline Pardo /mulato & $\begin{array}{l}-2,631 * * * \\
(0,605)\end{array}$ & $\begin{array}{l}-0,349 \\
(0,614)\end{array}$ & $\begin{array}{l}3,659 \\
(2,603)\end{array}$ \\
\hline Negro & $\begin{array}{l}-18,987 * * * \\
(1,398)\end{array}$ & $\begin{array}{l}-13,970 * * * \\
(1,428)\end{array}$ & $\begin{array}{l}-8,162 \\
(7,045)\end{array}$ \\
\hline Amarelo /índio & $\begin{array}{l}-1,540 \\
(1,056)\end{array}$ & $\begin{array}{l}-0,527 \\
(1,048)\end{array}$ & $\begin{array}{l}4,897 \\
(4,731)\end{array}$ \\
\hline Mora pai e mãe & $\begin{array}{l}5,508 * * * \\
(0,620)\end{array}$ & $\begin{array}{l}5,026 * * * \\
(0,633)\end{array}$ & $\begin{array}{l}1,239 \\
(2,860)\end{array}$ \\
\hline Estudo da mãe: & & & \\
\hline Nunca estudou & Base & Base & Base \\
\hline 1à $4^{\mathrm{a}}$ série & $\begin{array}{l}4,355 \\
(3,268)\end{array}$ & $\begin{array}{l}5,507 * \\
(3,193)\end{array}$ & $\begin{array}{l}-9,260 \\
(9,759)\end{array}$ \\
\hline $5^{\mathrm{a}}$ à $8^{\mathrm{a}}$ série & $\begin{array}{l}11,785 * * * \\
(3,189)\end{array}$ & $\begin{array}{l}12,459 * * * \\
(3,156)\end{array}$ & $\begin{array}{l}-10,127 \\
(8,609)\end{array}$ \\
\hline Ensino médio & $\begin{array}{l}21,600 * * * \\
(3,118)\end{array}$ & $\begin{array}{l}19,528 * * * \\
(3,043)\end{array}$ & $\begin{array}{l}4,994 \\
(8,093)\end{array}$ \\
\hline Faculdade & $\begin{array}{l}26,372 * * * \\
(3,105)\end{array}$ & $\begin{array}{l}20,461 * * * \\
(3,046)\end{array}$ & $\begin{array}{l}-1,222 \\
(8,004)\end{array}$ \\
\hline Aluno não sabe & $\begin{array}{l}17,104 * * * \\
(3,094)\end{array}$ & $\begin{array}{l}14,820 * * * \\
(3,033)\end{array}$ & $\begin{array}{l}-9,044 \\
(7,880)\end{array}$ \\
\hline Professores & & & \\
\hline Homem & $\begin{array}{l}-0,846 \\
(1,346)\end{array}$ & $\begin{array}{l}1,161 \\
(2,165)\end{array}$ & $\begin{array}{l}0,880 \\
(2,395)\end{array}$ \\
\hline Até 29 anos & Base & Base & Base \\
\hline De 30 a 40 anos & $\begin{array}{l}0,771 \\
(0,738)\end{array}$ & $\begin{array}{l}1,063 \\
(1,355)\end{array}$ & $\begin{array}{l}1,079 \\
(1,338)\end{array}$ \\
\hline 40 ou mais & $\begin{array}{l}2,003 * * \\
(0,936)\end{array}$ & $\begin{array}{l}-0,522 \\
(1,710)\end{array}$ & $\begin{array}{l}0,485 \\
(1,836)\end{array}$ \\
\hline Tem ensino superior & $\begin{array}{l}3,651 * * * \\
(0,634)\end{array}$ & $\begin{array}{l}0,252 \\
(1,309)\end{array}$ & $\begin{array}{l}-0,118 \\
(1,261)\end{array}$ \\
\hline
\end{tabular}




\begin{tabular}{|c|c|c|c|}
\hline Variáveis & $\begin{array}{l}\text { MQO agrupados } \\
\text { (dados de indivíduos) }\end{array}$ & $\begin{array}{l}\text { Efeitos Fixos } \\
\text { (dados de indivíduos) }\end{array}$ & $\begin{array}{l}\text { Efeitos Fixos } \\
\text { (dados de escola) }\end{array}$ \\
\hline Fez curso capacitação & $\begin{array}{l}1,555^{*} \\
(0,818)\end{array}$ & $\begin{array}{l}0,144 \\
(1,421)\end{array}$ & $\begin{array}{l}0,946 \\
(1,430)\end{array}$ \\
\hline Leciona há mais de 15 anos & $\begin{array}{l}2,128 * * * \\
(0,743)\end{array}$ & $\begin{array}{l}0,129 \\
(1,342)\end{array}$ & $\begin{array}{l}0,570 \\
(1,502)\end{array}$ \\
\hline $\begin{array}{l}\text { Diretores } \\
\text { Exerce função há menos de } 5 \text { anos }\end{array}$ & Base & Base & Base \\
\hline Exerce função entre 5 e 10 anos & $\begin{array}{l}-1,220 \\
(1,009)\end{array}$ & $\begin{array}{l}-1,781 \\
(1,783)\end{array}$ & $\begin{array}{l}-0,553 \\
(1,897)\end{array}$ \\
\hline Exerce função há mais de 10 anos & $\begin{array}{l}3,067 * * * \\
(1,003)\end{array}$ & $\begin{array}{l}-4,055^{* *} \\
(1,946)\end{array}$ & $\begin{array}{l}-4,124 * * \\
(2,032)\end{array}$ \\
\hline $\begin{array}{l}\text { Direção da escola há menos de } 5 \\
\text { anos }\end{array}$ & Base & Base & Base \\
\hline Direção da escola entre 5 e 10 anos & $\begin{array}{l}-0,198 \\
(0,895)\end{array}$ & $\begin{array}{l}2,795^{*} \\
(1,576)\end{array}$ & $\begin{array}{l}1,125 \\
(1,775)\end{array}$ \\
\hline $\begin{array}{l}\text { Direção da escola há mais de } 10 \\
\text { anos } \\
\text { Problema com professores faltosos }\end{array}$ & $\begin{array}{l}-0,655 \\
(0,952) \\
-5,535^{* * *} \\
(1,182)\end{array}$ & $\begin{array}{l}4,354^{* *} \\
(1,906) \\
0,331 \\
(2,246)\end{array}$ & $\begin{array}{l}2,381 \\
(2,223) \\
3,317 \\
(2,216)\end{array}$ \\
\hline $\begin{array}{l}\text { Assumiu o cargo por concurso } \\
\text { público, } \\
\text { Seleção, eleição. }\end{array}$ & Base & Base & Base \\
\hline $\begin{array}{l}\text { Assumiu cargo por indicação, } \\
\text { Outras formas }\end{array}$ & $\begin{array}{l}-1,334 * * \\
(0,677)\end{array}$ & $\begin{array}{l}-2,082 \\
(1,274)\end{array}$ & $\begin{array}{l}-1,390 \\
(1,393)\end{array}$ \\
\hline $\begin{array}{l}\text { Projeto Pedagógico elaborado pela } \\
\text { Secretaria } \\
\text { da Educação }\end{array}$ & Base & Base & Base \\
\hline $\begin{array}{l}\text { Projeto Pedagógico pelo diretor e } \\
\text { professores } \\
\text { Não houve projeto pedagógico no } \\
\text { ano } \\
\text { Escola }\end{array}$ & $\begin{array}{l}2,763 * * * \\
(0,810) \\
-1,093 \\
(1,746)\end{array}$ & $\begin{array}{l}-3,255^{* *} \\
(1,658) \\
-0,278 \\
(3,362)\end{array}$ & $\begin{array}{l}-1,978 \\
(1,576) \\
-0,729 \\
(3,281)\end{array}$ \\
\hline Região rural & $\begin{array}{l}-17,725 * * * \\
(3,756)\end{array}$ & & \\
\hline Biblioteca & $\begin{array}{l}-2,630 * * * \\
(1,019)\end{array}$ & $\begin{array}{l}-1,698 \\
(1,638)\end{array}$ & $\begin{array}{l}-0,676 \\
(2,066)\end{array}$ \\
\hline Laboratório de informática & $\begin{array}{l}3,079 * * * \\
(0,815)\end{array}$ & $\begin{array}{l}2,115 \\
(1,827)\end{array}$ & $\begin{array}{l}2,048 \\
(1,829)\end{array}$ \\
\hline Laboratório de ciências & $\begin{array}{l}5,489 * * * \\
(0,689)\end{array}$ & $\begin{array}{l}0,714 \\
(1,608)\end{array}$ & $\begin{array}{l}-1,254 \\
(1,754)\end{array}$ \\
\hline Quadra de esportes & $\begin{array}{l}3,047 * * * \\
(0,870)\end{array}$ & $\begin{array}{l}-0,465 \\
(2,071)\end{array}$ & $\begin{array}{l}-2,373 \\
(1,879)\end{array}$ \\
\hline Programa TV na escola & $\begin{array}{l}-3,565^{* *} \\
(1,596)\end{array}$ & $\begin{array}{l}1,184 \\
(2,770)\end{array}$ & $\begin{array}{l}-0,100 \\
(3,313)\end{array}$ \\
\hline Merenda & $\begin{array}{l}-4,678 * * * \\
(1,019)\end{array}$ & $\begin{array}{l}2,681 \\
(2,109)\end{array}$ & $\begin{array}{l}5,785^{* *} \\
(2,395)\end{array}$ \\
\hline Professores no EF & $\begin{array}{l}0,244 * * * \\
(0,024)\end{array}$ & $\begin{array}{l}0,095 \\
(0,062)\end{array}$ & $\begin{array}{l}0,064 \\
(0,084)\end{array}$ \\
\hline Turmas na $4^{\mathrm{a}}$ série diurnas & $\begin{array}{l}1,581 * * * \\
(0,392)\end{array}$ & $\begin{array}{l}-0,417 \\
(0,764)\end{array}$ & $\begin{array}{l}-0,586 \\
(1,081)\end{array}$ \\
\hline Turmas na $4^{\mathrm{a}}$ série noturnas & $\begin{array}{l}1,412 \\
(2,537)\end{array}$ & $\begin{array}{l}-4,656 \\
(3,774)\end{array}$ & $\begin{array}{l}-5,150 \\
(7,801)\end{array}$ \\
\hline Matrículas na $4^{\mathrm{a}}$ série & $\begin{array}{l}-0,067 * * * \\
(0,011)\end{array}$ & $\begin{array}{l}-0,058^{* * *} \\
(0,019)\end{array}$ & $\begin{array}{l}-0,047^{*} \\
(0,028)\end{array}$ \\
\hline d_1997 & Base & Base & Base \\
\hline d_1999 & $\begin{array}{l}1,024 \\
(16,174)\end{array}$ & $\begin{array}{l}-20,672 \\
(19,974)\end{array}$ & $\begin{array}{l}-18,884 \\
(43,365)\end{array}$ \\
\hline
\end{tabular}




\begin{tabular}{|c|c|c|c|}
\hline Variáveis & $\begin{array}{l}\text { MQO agrupados } \\
\text { (dados de indivíduos) }\end{array}$ & $\begin{array}{l}\text { Efeitos Fixos } \\
\text { (dados de indivíduos) }\end{array}$ & $\begin{array}{l}\text { Efeitos Fixos } \\
\text { (dados de escola) }\end{array}$ \\
\hline d_2001 & $\begin{array}{l}5,293 \\
(16,185)\end{array}$ & $\begin{array}{l}-16,674 \\
(19,923)\end{array}$ & $\begin{array}{l}-17,103 \\
(43,336)\end{array}$ \\
\hline d_2003 & $\begin{array}{l}1,874 \\
(16,207)\end{array}$ & $\begin{array}{l}-18,463 \\
(20,005)\end{array}$ & $\begin{array}{l}-17,184 \\
(43,369)\end{array}$ \\
\hline d_2005 & $\begin{array}{l}6,761 \\
(15,206)\end{array}$ & $\begin{array}{l}-11,344 \\
(19,995)\end{array}$ & $\begin{array}{l}-11,068 \\
(43,331)\end{array}$ \\
\hline Constante & $\begin{array}{l}168,424 * * * \\
(16,687)\end{array}$ & $\begin{array}{l}223,954 * * * \\
(19,945)\end{array}$ & $\begin{array}{l}239,394 * * * \\
(44,436)\end{array}$ \\
\hline Observações & 23.079 & 23.079 & 2.091 \\
\hline Grupos & & 971 & 971 \\
\hline R2 Within & & 0,0575 & 0,1453 \\
\hline R2 Between & & 0,2081 & 0,0926 \\
\hline R2 Total & 0,1858 & 0,0710 & 0,0866 \\
\hline Hausman & & Chi2 $(42)=334,40$ & Chi2 $(41)=269,44$ \\
\hline & & Prob $>$ chi $2=0,000$ & Prob $>$ chi $2=0,000$ \\
\hline
\end{tabular}

Notas: (a) Desvios padrões ajustados para 971 "clusters" de escola.

Graus de significância: * $10 \% ; * * 5 \%, * * * 1 \%$.

As Tabelas 12 e 13 reportam as estimações realizadas com o painel mais curto para escolas públicas e privadas, respectivamente. 
Tabela 12- Proficiência em matemática $4^{\text {a }}$ série - escolas públicas (painel 1999, 2001, 2003 e 2005)

\begin{tabular}{|c|c|c|c|}
\hline Variáveis & $\begin{array}{l}\text { MQO agrupados } \\
\text { (dados de indivíduos) }\end{array}$ & $\begin{array}{l}\text { Efeitos Fixos } \\
\text { (dados de indivíduos) }\end{array}$ & $\begin{array}{l}\text { Efeitos Fixos } \\
\text { (dados de escola) }\end{array}$ \\
\hline \multicolumn{4}{|l|}{ Alunos } \\
\hline Homem & $\begin{array}{l}5,388 * * * \\
(0,406)\end{array}$ & $\begin{array}{l}4,975 * * * \\
(0,391)\end{array}$ & $\begin{array}{l}-2,431 \\
(2,635)\end{array}$ \\
\hline 9 anos & Base & Base & Base \\
\hline 10 anos & $\begin{array}{l}1,049 \\
(0,749)\end{array}$ & $\begin{array}{l}-0,533 \\
(0,728)\end{array}$ & $\begin{array}{l}12,197 * * * \\
(4,355)\end{array}$ \\
\hline 11 anos & $\begin{array}{l}-9,534 * * * \\
(0,749)\end{array}$ & $\begin{array}{l}-9,043 * * * \\
(0,799)\end{array}$ & $\begin{array}{l}5,657 \\
(4,764)\end{array}$ \\
\hline 12 ou mais & $\begin{array}{l}-14,540^{* * * *} \\
(0,776)\end{array}$ & $\begin{array}{l}-13,886^{* * *} \\
(0,783)\end{array}$ & $\begin{array}{l}-2,878 \\
(4,300)\end{array}$ \\
\hline Computador & $\begin{array}{l}6,124 * * * \\
(0,761)\end{array}$ & $\begin{array}{l}0,095 \\
(0,789)\end{array}$ & $\begin{array}{l}-6,869 \\
(4,668)\end{array}$ \\
\hline Branco & Base & Base & Base \\
\hline Pardo /mulato & $\begin{array}{l}-0,631 \\
(0,457)\end{array}$ & $\begin{array}{l}2,169 * * * \\
(0,480)\end{array}$ & $\begin{array}{l}5,412 * * \\
(2,449)\end{array}$ \\
\hline Negro & $\begin{array}{l}-10,441 * * * \\
(0,626)\end{array}$ & $\begin{array}{l}-6,590 * * * \\
(0,682)\end{array}$ & $\begin{array}{l}1,685 \\
(3,962)\end{array}$ \\
\hline Amarelo /índio & $\begin{array}{l}-0,947 \\
(0,840)\end{array}$ & $\begin{array}{l}0,945 \\
(0,792)\end{array}$ & $\begin{array}{l}5,720 \\
(4,793)\end{array}$ \\
\hline Mora pai e mãe & $\begin{array}{l}2,380 * * * \\
(0,415)\end{array}$ & $\begin{array}{l}1,051 * * \\
(0,422)\end{array}$ & $\begin{array}{l}3,011 \\
(2,575)\end{array}$ \\
\hline Estudo da mãe: & & & \\
\hline Nunca estudou & Base & Base & Base \\
\hline de $1^{\mathrm{a}}$ à $4^{\mathrm{a}}$ série & $\begin{array}{l}4,096 * * * \\
(0,828)\end{array}$ & $\begin{array}{l}2,668 * * * \\
(0,829)\end{array}$ & $\begin{array}{l}-6,128 \\
(4,065)\end{array}$ \\
\hline de $5^{\mathrm{a}}$ à $8^{\mathrm{a}}$ série & $\begin{array}{l}6,706^{* * * *} \\
(0,879)\end{array}$ & $\begin{array}{l}4,840 * * * \\
(0,898)\end{array}$ & $\begin{array}{l}-12,203 * * * \\
(4,581)\end{array}$ \\
\hline Ensino médio & $\begin{array}{l}13,446 * * * \\
(0,966)\end{array}$ & $\begin{array}{l}9,901 * * * \\
(0,996)\end{array}$ & $\begin{array}{l}-4,713 \\
(5,284)\end{array}$ \\
\hline Faculdade & $\begin{array}{l}10,904 * * * \\
(1,139)\end{array}$ & $\begin{array}{l}6,006 * * * \\
(1,186)\end{array}$ & $\begin{array}{l}-5,239 \\
(6,571)\end{array}$ \\
\hline Aluno não sabe & $\begin{array}{l}5,620^{* * * *} \\
(0,854)\end{array}$ & $\begin{array}{l}3,429 * * * \\
(0,879)\end{array}$ & $\begin{array}{l}-14,896 * * * \\
(3,980)\end{array}$ \\
\hline Aluno trabalha for a & $\begin{array}{l}-8,374 * * * \\
(0,539)\end{array}$ & $\begin{array}{l}-7,120 * * * \\
(0,572)\end{array}$ & $\begin{array}{l}2,946 \\
(2,727)\end{array}$ \\
\hline Professores & & & \\
\hline Homem & $\begin{array}{l}-1,920^{* * *} \\
(0,679)\end{array}$ & $\begin{array}{l}1,416 \\
(1,460)\end{array}$ & $\begin{array}{l}2,256 \\
(1,533)\end{array}$ \\
\hline Até 29 anos & Base & Base & Base \\
\hline 30 a 40 anos & $\begin{array}{l}0,253 \\
(0,559)\end{array}$ & $\begin{array}{l}0,949 \\
(1,213)\end{array}$ & $\begin{array}{l}0,982 \\
(1,202)\end{array}$ \\
\hline 40 ou mais & $\begin{array}{l}0,618 \\
(0,655)\end{array}$ & $\begin{array}{l}0,884 \\
(1,320)\end{array}$ & $\begin{array}{l}1,223 \\
(1,513)\end{array}$ \\
\hline Tem ensino superior & $\begin{array}{l}3,735 * * * \\
(0,435)\end{array}$ & $\begin{array}{l}0,210 \\
(0,904)\end{array}$ & $\begin{array}{l}0,862 \\
(1,047)\end{array}$ \\
\hline Fez curso capacitação & $\begin{array}{l}-0,183 \\
(0,538)\end{array}$ & $\begin{array}{l}0,596 \\
(1,018)\end{array}$ & $\begin{array}{l}-1,214 \\
(1,128)\end{array}$ \\
\hline Leciona há mais de 15 anos & $\begin{array}{l}-0,528 \\
(0,526)\end{array}$ & $\begin{array}{l}-0,144 \\
(1,050)\end{array}$ & $\begin{array}{l}0,724 \\
(1,243)\end{array}$ \\
\hline Diretores & & & \\
\hline Problema com professores faltosos & $\begin{array}{l}-1,148 * * \\
(0,485)\end{array}$ & $\begin{array}{l}0,047 \\
(0,997)\end{array}$ & $\begin{array}{l}0,868 \\
(1,132)\end{array}$ \\
\hline Exerce função há menos de 5 anos & Base & Base & Base \\
\hline Exerce função entre 5 e 10 anos & $\begin{array}{l}-1,948 * * * \\
(0,631)\end{array}$ & $\begin{array}{l}-1,485 \\
(1,530)\end{array}$ & $\begin{array}{l}-1,519 \\
(1,378)\end{array}$ \\
\hline
\end{tabular}




\begin{tabular}{|c|c|c|c|}
\hline Variáveis & $\begin{array}{l}\text { MQO agrupados } \\
\text { (dados de indivíduos) }\end{array}$ & $\begin{array}{l}\text { Efeitos Fixos } \\
\text { (dados de indivíduos) }\end{array}$ & $\begin{array}{l}\text { Efeitos Fixos } \\
\text { (dados de escola) }\end{array}$ \\
\hline Exerce função há mais de 10 anos & $\begin{array}{l}1,808^{* *} \\
(0,878)\end{array}$ & $\begin{array}{l}3,161 \\
(2,681)\end{array}$ & $\begin{array}{l}0,819 \\
(2,184)\end{array}$ \\
\hline $\begin{array}{l}\text { Direção da escola há menos de } 5 \\
\text { anos }\end{array}$ & Base & Base & Base \\
\hline Direção da escola entre 5 e 10 anos & $\begin{array}{l}2,376^{* * * *} \\
(0,694)\end{array}$ & $\begin{array}{l}0,754 \\
(1,883)\end{array}$ & $\begin{array}{l}1,181 \\
(1,565)\end{array}$ \\
\hline $\begin{array}{l}\text { Direção da escola há mais de } 10 \\
\text { anos }\end{array}$ & $\begin{array}{l}2,412 * * \\
(1,115)\end{array}$ & $\begin{array}{l}-2,631 \\
(3,482)\end{array}$ & $\begin{array}{l}0,419 \\
(3,133)\end{array}$ \\
\hline $\begin{array}{l}\text { Assumiu o cargo por concurso } \\
\text { público, } \\
\text { Seleção, eleição. }\end{array}$ & Base & Base & Base \\
\hline $\begin{array}{l}\text { Assumiu cargo por indicação, outras } \\
\text { formas }\end{array}$ & $\begin{array}{l}-1,725^{* * *} \\
(0,417)\end{array}$ & $\begin{array}{l}1,019 \\
(1,368)\end{array}$ & $\begin{array}{l}1,393 \\
(1,198)\end{array}$ \\
\hline $\begin{array}{l}\text { Projeto Pedagógico elaborado pela } \\
\text { Secretaria } \\
\text { da Educação }\end{array}$ & Base & Base & Base \\
\hline $\begin{array}{l}\text { Projeto pedagógico elaborado pelo } \\
\text { diretor e professores }\end{array}$ & $\begin{array}{l}1,368 * * * \\
(0,509)\end{array}$ & $\begin{array}{l}1,175 \\
(1,057)\end{array}$ & $\begin{array}{l}-0,513 \\
(1,084)\end{array}$ \\
\hline $\begin{array}{l}\text { Não houve projeto pedagógico no } \\
\text { ano } \\
\text { Turmas }\end{array}$ & $\begin{array}{l}-1,282^{*} \\
(0,719)\end{array}$ & $\begin{array}{l}0,083 \\
(1,485)\end{array}$ & $\begin{array}{l}-0,675 \\
(1,535)\end{array}$ \\
\hline $\begin{array}{l}\text { Não teve nenhum professor de } \\
\text { matemática no ano }\end{array}$ & Base & Base & Base \\
\hline $\begin{array}{l}\text { Teve um professor de matemática } \\
\text { no ano }\end{array}$ & $\begin{array}{l}1,684^{*} \\
(1,022)\end{array}$ & $\begin{array}{l}2,083 \\
(1,822)\end{array}$ & $\begin{array}{l}0,864 \\
(2,023)\end{array}$ \\
\hline $\begin{array}{l}\text { Teve dois professores de } \\
\text { matemática no ano }\end{array}$ & $\begin{array}{l}1,939^{*} \\
(1,108)\end{array}$ & $\begin{array}{l}0,867 \\
(2,003)\end{array}$ & $\begin{array}{l}-0,560 \\
(2,228)\end{array}$ \\
\hline $\begin{array}{l}\text { Não ficou nenhum mês se professor } \\
\text { de matemática }\end{array}$ & Base & Base & Base \\
\hline $\begin{array}{l}\text { Ficou pelo menos } 1 \text { mês sem } \\
\text { professor }\end{array}$ & $\begin{array}{l}-3,867 * * * \\
(0,939)\end{array}$ & $\begin{array}{l}-1,346 \\
(1,674)\end{array}$ & $\begin{array}{l}0,790 \\
(2,078)\end{array}$ \\
\hline Tamanho médio das turmas & $\begin{array}{l}-0,184 * * * \\
(0,029)\end{array}$ & $\begin{array}{l}-0,076 \\
(0,068)\end{array}$ & $\begin{array}{l}-0,047 \\
(0,072)\end{array}$ \\
\hline $\begin{array}{l}\text { Turno: menos de } 4 \text { horas aula por } \\
\text { dia }\end{array}$ & Base & Base & Base \\
\hline Turno: de 4 a 5 horas aula por dia & $\begin{array}{l}1,609 * * * \\
(0,422)\end{array}$ & $\begin{array}{l}-0,897 \\
(1,118)\end{array}$ & $\begin{array}{l}-0,697 \\
(1,205)\end{array}$ \\
\hline Turno: mais de 5 horas aula por dia & $\begin{array}{l}12,061 * * * \\
(1,147)\end{array}$ & $\begin{array}{l}0,701 \\
(4,045)\end{array}$ & $\begin{array}{l}2,114 \\
(3,761)\end{array}$ \\
\hline Escola & & & \\
\hline Região rural & $\begin{array}{l}-4,494 * * * \\
(0,784)\end{array}$ & - & - \\
\hline Administração municipal & $\begin{array}{l}-0,415 \\
(0,444)\end{array}$ & - & - \\
\hline Biblioteca & $\begin{array}{l}1,256^{* * * *} \\
(0,470)\end{array}$ & $\begin{array}{l}-2,291 * \\
(1,324)\end{array}$ & $\begin{array}{l}-2,147 \\
(1,288)\end{array}$ \\
\hline Laboratório de informática & $\begin{array}{l}-0,838 \\
(0,661)\end{array}$ & $\begin{array}{l}0,626 \\
(1,511)\end{array}$ & $\begin{array}{l}1,144 \\
(1,687)\end{array}$ \\
\hline Laboratório de ciências & $\begin{array}{l}8,157 * * * \\
(0,717)\end{array}$ & $\begin{array}{l}3,040 \\
(2,583)\end{array}$ & $\begin{array}{l}1,682 \\
(2,112)\end{array}$ \\
\hline Quadra de esportes & $\begin{array}{l}0,759 \\
(0,470)\end{array}$ & $\begin{array}{l}2,344 \\
(1,509)\end{array}$ & $\begin{array}{l}1,913 \\
(1,472)\end{array}$ \\
\hline Internet & $\begin{array}{l}2,442 * * * \\
(0,620)\end{array}$ & $\begin{array}{l}-0,843 \\
(1,609)\end{array}$ & $\begin{array}{l}-1,245 \\
(1,409)\end{array}$ \\
\hline Programa TV na escola & $\begin{array}{l}-0,040 \\
(0,431)\end{array}$ & $\begin{array}{l}-2,120 * * \\
(1,069)\end{array}$ & $\begin{array}{l}-1,387 \\
(1,087)\end{array}$ \\
\hline Merenda & 1,290 & $-1,866$ & 0,929 \\
\hline
\end{tabular}




\begin{tabular}{|c|c|c|c|}
\hline Variáveis & $\begin{array}{l}\text { MQO agrupados } \\
\text { (dados de indivíduos) }\end{array}$ & $\begin{array}{l}\text { Efeitos Fixos } \\
\text { (dados de indivíduos) }\end{array}$ & $\begin{array}{l}\text { Efeitos Fixos } \\
\text { (dados de escola) }\end{array}$ \\
\hline & $(2,164)$ & $(3,841)$ & $(3,717)$ \\
\hline Professores no EF & $\begin{array}{l}-0,020 \\
(0,014)\end{array}$ & $\begin{array}{l}0,015 \\
(0,063)\end{array}$ & $\begin{array}{l}0,066 \\
(0,067)\end{array}$ \\
\hline \multicolumn{4}{|l|}{ Uso de computadores: } \\
\hline Para fins pedagógicos & $\begin{array}{l}2,611 * * * \\
(0,579)\end{array}$ & $\begin{array}{l}0,934 \\
(1,358)\end{array}$ & $\begin{array}{l}0,347 \\
(1,325)\end{array}$ \\
\hline Para uso em sala de aula & $\begin{array}{l}4,234 * * \\
(1,924)\end{array}$ & $\begin{array}{l}0,459 \\
(2,984)\end{array}$ & $\begin{array}{l}-2,662 \\
(4,856)\end{array}$ \\
\hline Para uso na administração & $\begin{array}{l}3,621 * * * \\
(0,495)\end{array}$ & $\begin{array}{l}-2,180^{*} \\
(1,180)\end{array}$ & $\begin{array}{l}-2,438 * * \\
(1,249)\end{array}$ \\
\hline Turmas na $4^{\mathrm{a}}$ série diurnas & $\begin{array}{l}-0,375 \\
(0,271)\end{array}$ & $\begin{array}{l}0,074 \\
(0,548)\end{array}$ & $\begin{array}{l}0,465 \\
(0,672)\end{array}$ \\
\hline Turmas na $4^{\mathrm{a}}$ série noturnas & $\begin{array}{l}1,032^{*} \\
(0,542)\end{array}$ & $\begin{array}{l}-1,206 \\
(1,469)\end{array}$ & $\begin{array}{l}0,465 \\
(1,484)\end{array}$ \\
\hline Matrículas na $4^{\mathrm{a}}$ série & $\begin{array}{l}-0,004 \\
(0,007)\end{array}$ & $\begin{array}{l}-0,012 \\
(0,013)\end{array}$ & $\begin{array}{l}-0,032 * * \\
(0,016)\end{array}$ \\
\hline d 1997 & Base & Base & Base \\
\hline d_2001 & $\begin{array}{l}-4,473 * * * \\
(0,712)\end{array}$ & $\begin{array}{l}-4,355^{* * *} \\
(1,169)\end{array}$ & $\begin{array}{l}-7,258 * * * \\
(1,222)\end{array}$ \\
\hline d_2003 & $\begin{array}{l}-6,705^{* * *} \\
(0,757)\end{array}$ & $\begin{array}{l}-6,180 * * * \\
(1,404)\end{array}$ & $\begin{array}{l}-7,743 * * * \\
(1,476)\end{array}$ \\
\hline d_2005 & $\begin{array}{l}-5,731 * * * \\
(0,851)\end{array}$ & $\begin{array}{l}-2,052 \\
(1,667)\end{array}$ & $\begin{array}{l}-2,478 \\
(1,811)\end{array}$ \\
\hline Constante & $\begin{array}{l}173,046^{* * *} \\
(2,871)\end{array}$ & $\begin{array}{l}179,950 * * * \\
(5,302)\end{array}$ & $\begin{array}{l}177,230 * * * \\
(7,719)\end{array}$ \\
\hline Observações & 33.173 & 33.173 & 2.752 \\
\hline Grupos & & 1.413 & 1.413 \\
\hline R2 Within & & 0,0524 & 0,1079 \\
\hline R2 Between & & 0,2364 & 0,0047 \\
\hline R2 Total & 0,1325 & 0,0911 & 0,0252 \\
\hline Hausman & & - & $\begin{array}{l}\text { Chi } 2(52)=305,00 \\
\text { Prob }>\text { chi } 2=0,000\end{array}$ \\
\hline
\end{tabular}

Notas: (a) Desvios padrões ajustados para 1.413 "clusters" de escola.

Graus de significância: * $10 \% ; * * 5 \%, * * * 1 \%$. 
Tabela 13- proficiência em matemática $4^{\text {a }}$ série - escolas privadas (painel 1999, 2001, 2003 e 2005)

\begin{tabular}{|c|c|c|c|}
\hline Variáveis & $\begin{array}{l}\text { MQO agrupados } \\
\text { (dados de indivíduos) }\end{array}$ & $\begin{array}{l}\text { Efeitos Fixos } \\
\text { (dados de indivíduos) }\end{array}$ & $\begin{array}{l}\text { Efeitos Fixos } \\
\text { (dados de escola) }\end{array}$ \\
\hline \multicolumn{4}{|l|}{ Alunos } \\
\hline Homem & $\begin{array}{l}6,594 * * * \\
(0,590)\end{array}$ & $\begin{array}{l}6,969 * * * \\
(0,568)\end{array}$ & $\begin{array}{l}9,493 * * * \\
(3,025)\end{array}$ \\
\hline 9 anos & Base & Base & Base \\
\hline 10 anos & $\begin{array}{l}3,423 * * * \\
(0,792)\end{array}$ & $\begin{array}{l}0,057 \\
(0,833)\end{array}$ & $\begin{array}{l}3,492 \\
(3,719)\end{array}$ \\
\hline 11 anos & $\begin{array}{l}-5,069 * * * \\
(1,096)\end{array}$ & $\begin{array}{l}-8,952 * * * \\
(1,201)\end{array}$ & $\begin{array}{l}-14,927^{* * * *} \\
(5,306)\end{array}$ \\
\hline 12 ou mais & $\begin{array}{l}-26,083^{* * *} \\
(1,646)\end{array}$ & $\begin{array}{l}-23,982^{* * * *} \\
(1,910)\end{array}$ & $\begin{array}{l}-28,527 * * * \\
(7,559)\end{array}$ \\
\hline Computador & $\begin{array}{l}8,606 * * * \\
(0,666)\end{array}$ & $\begin{array}{l}1,033 \\
(0,694)\end{array}$ & $\begin{array}{l}-0,901 \\
(3,305)\end{array}$ \\
\hline Branco & Base & Base & Base \\
\hline Pardo /mulato & $\begin{array}{l}-2,552 * * * \\
(0,652)\end{array}$ & $\begin{array}{l}-0,214 \\
(0,669)\end{array}$ & $\begin{array}{l}4,432 \\
(2,944)\end{array}$ \\
\hline Negro & $\begin{array}{l}-18,252^{* * *} \\
(1,499)\end{array}$ & $\begin{array}{l}-13,783^{* * *} \\
(1,524)\end{array}$ & $\begin{array}{l}-5,706 \\
(8,000)\end{array}$ \\
\hline Amarelo /índio & $\begin{array}{l}-2,168^{*} \\
(1,151)\end{array}$ & $\begin{array}{l}-1,108 \\
(1,116)\end{array}$ & $\begin{array}{l}3,252 \\
(5,347)\end{array}$ \\
\hline Mora pai e mãe & $\begin{array}{l}5,447 * * * \\
(0,668)\end{array}$ & $\begin{array}{l}5,002 * * * \\
(0,710)\end{array}$ & $\begin{array}{l}0,542 \\
(3,206)\end{array}$ \\
\hline Estudo da mãe: & & & \\
\hline Nunca estudou & Base & Base & Base \\
\hline de $1^{\mathrm{a}}$ à $4^{\mathrm{a}}$ série & $\begin{array}{l}1,971 \\
(3,497)\end{array}$ & $\begin{array}{l}3,280 \\
(3,448)\end{array}$ & $\begin{array}{l}-8,107 \\
(11,062)\end{array}$ \\
\hline de $5^{\mathrm{a}}$ à $8^{\mathrm{a}}$ série & $\begin{array}{l}9,655^{* * * *} \\
(3,400)\end{array}$ & $\begin{array}{l}10,010^{* * *} \\
(3,378)\end{array}$ & $\begin{array}{l}-11,242 \\
(9,704)\end{array}$ \\
\hline Ensino médio & $\begin{array}{l}19,462 * * * \\
(3,323)\end{array}$ & $\begin{array}{l}17,263 * * * \\
(3,295)\end{array}$ & $\begin{array}{l}3,234 \\
(9,226)\end{array}$ \\
\hline Faculdade & $\begin{array}{l}23,754 * * * \\
(3,307)\end{array}$ & $\begin{array}{l}17,953 * * * \\
(3,273)\end{array}$ & $\begin{array}{l}-2,151 \\
(9,084)\end{array}$ \\
\hline Aluno não sabe & $\begin{array}{l}14,916^{* * *} \\
(3,294)\end{array}$ & $\begin{array}{l}12,602 * * * \\
(3,261)\end{array}$ & $\begin{array}{l}-9,647 \\
(8,962)\end{array}$ \\
\hline Aluno trabalha for a & $\begin{array}{l}-14,906^{* * * *} \\
(1,248)\end{array}$ & $\begin{array}{l}-12,001 * * * \\
(1,257)\end{array}$ & $\begin{array}{l}-10,762 * * \\
(5,225)\end{array}$ \\
\hline Professores & & & \\
\hline Homem & $\begin{array}{l}-1,030 \\
(1,423)\end{array}$ & $\begin{array}{l}0,766 \\
(2,645)\end{array}$ & $\begin{array}{l}1,874 \\
(2,813)\end{array}$ \\
\hline Até 29 anos & Base & Base & Base \\
\hline 30 a 40 anos & $\begin{array}{l}1,592 * * \\
(0,792)\end{array}$ & $\begin{array}{l}0,555 \\
(1,487)\end{array}$ & $\begin{array}{l}0,476 \\
(1,524)\end{array}$ \\
\hline 40 ou mais & $\begin{array}{l}2,539 * * \\
(1,002)\end{array}$ & $\begin{array}{l}-1,225 \\
(1,952)\end{array}$ & $\begin{array}{l}-0,370 \\
(2,030)\end{array}$ \\
\hline Tem ensino superior & $\begin{array}{l}2,894 * * * \\
(0,677)\end{array}$ & $\begin{array}{l}0,540 \\
(1,438)\end{array}$ & $\begin{array}{l}0,097 \\
(1,404)\end{array}$ \\
\hline Fez curso capacitação & $\begin{array}{l}0,909 \\
(0,882)\end{array}$ & $\begin{array}{l}1,016 \\
(1,565)\end{array}$ & $\begin{array}{l}1,472 \\
(1,605)\end{array}$ \\
\hline Leciona há mais de 15 anos & $\begin{array}{l}2,376 * * * \\
(0,795)\end{array}$ & $\begin{array}{l}1,123 \\
(1,556)\end{array}$ & $\begin{array}{l}1,295 \\
(1,688)\end{array}$ \\
\hline Diretores & & & \\
\hline Problema com professores faltosos & $\begin{array}{l}-4,970 * * * \\
(1,308)\end{array}$ & $\begin{array}{l}-0,360 \\
(2,528)\end{array}$ & $\begin{array}{l}2,706 \\
(2,500)\end{array}$ \\
\hline
\end{tabular}




\begin{tabular}{|c|c|c|c|}
\hline Variáveis & $\begin{array}{l}\text { MQO agrupados } \\
\text { (dados de indivíduos) }\end{array}$ & $\begin{array}{l}\text { Efeitos Fixos } \\
\text { (dados de indivíduos) }\end{array}$ & $\begin{array}{l}\text { Efeitos Fixos } \\
\text { (dados de escola) }\end{array}$ \\
\hline Exerce função há menos de 5 anos & Base & Base & Base \\
\hline Exerce função entre 5 e 10 anos & $\begin{array}{l}-1,432 \\
(1,118)\end{array}$ & $\begin{array}{l}-2,281 \\
(2,101)\end{array}$ & $\begin{array}{l}-0,168 \\
(2,114)\end{array}$ \\
\hline Exerce função há mais de 10 anos & $\begin{array}{l}2,485^{* *} \\
(1,069)\end{array}$ & $\begin{array}{l}-4,789 * * \\
(2,105)\end{array}$ & $\begin{array}{l}-4,732 * * \\
(2,263)\end{array}$ \\
\hline Direção da escola há menos de 5 anos & Base & Base & Base \\
\hline Direção da escola entre 5 e 10 anos & $\begin{array}{l}-1,746^{*} \\
(0,989)\end{array}$ & $\begin{array}{l}2,143 \\
(1,807)\end{array}$ & $\begin{array}{l}0,834 \\
(1,993)\end{array}$ \\
\hline Direção da escola há mais de 10 anos & $\begin{array}{l}-0,993 \\
(1,017)\end{array}$ & $\begin{array}{l}4,150^{* *} \\
(2,037)\end{array}$ & $\begin{array}{l}3,231 \\
(2,486)\end{array}$ \\
\hline $\begin{array}{l}\text { Assumiu o cargo por concurso } \\
\text { público, } \\
\text { Seleção, eleição. }\end{array}$ & Base & Base & Base \\
\hline $\begin{array}{l}\text { Assumiu cargo por indicação, } \\
\text { Outras formas }\end{array}$ & $\begin{array}{l}-2,565^{* * *} \\
(0,741)\end{array}$ & $\begin{array}{l}-2,808^{*} \\
(1,472)\end{array}$ & $\begin{array}{l}-1,982 \\
(1,566)\end{array}$ \\
\hline $\begin{array}{l}\text { Projeto Pedagógico elaborado pela } \\
\text { Secretaria } \\
\text { da Educação }\end{array}$ & Base & Base & Base \\
\hline $\begin{array}{l}\text { Projeto Pedagógico elaborado pelo } \\
\text { diretor e professores }\end{array}$ & $\begin{array}{l}3,504 * * * \\
(0,875)\end{array}$ & $\begin{array}{l}-2,854^{*} \\
(1,666)\end{array}$ & $\begin{array}{l}-1,620 \\
(1,725)\end{array}$ \\
\hline Não houve Projeto Pedagógico no ano & $\begin{array}{l}-0,459 \\
(1,892)\end{array}$ & $\begin{array}{l}0,119 \\
(3,505)\end{array}$ & $\begin{array}{l}-1,085 \\
(3,654)\end{array}$ \\
\hline \multicolumn{4}{|l|}{ Turmas } \\
\hline $\begin{array}{l}\text { Não teve nenhum professor de } \\
\text { matemática no ano }\end{array}$ & Base & Base & Base \\
\hline $\begin{array}{l}\text { Teve um professor de } \\
\text { matemática no ano }\end{array}$ & $\begin{array}{l}5,211 * * * \\
(1,557)\end{array}$ & $\begin{array}{l}2,316 \\
(2,278)\end{array}$ & $\begin{array}{l}3,704 \\
(2,648)\end{array}$ \\
\hline $\begin{array}{l}\text { Teve dois professores de } \\
\text { matemática no ano }\end{array}$ & $\begin{array}{l}2,333 \\
(1,912)\end{array}$ & $\begin{array}{l}2,842 \\
(3,190)\end{array}$ & $\begin{array}{l}2,671 \\
(3,351)\end{array}$ \\
\hline $\begin{array}{l}\text { Não ficou nenhum mês se professor } \\
\text { de matemática }\end{array}$ & Base & Base & Base \\
\hline $\begin{array}{l}\text { Ficou pelo menos } 1 \text { mês sem } \\
\text { professor }\end{array}$ & $\begin{array}{l}-2,434 \\
(2,303)\end{array}$ & $\begin{array}{l}3,423 \\
(3,562)\end{array}$ & $\begin{array}{l}3,808 \\
(4,441)\end{array}$ \\
\hline Tamanho médio das turmas & $\begin{array}{l}-0,174 * * * \\
(0,042)\end{array}$ & $\begin{array}{l}-0,075 \\
(0,089)\end{array}$ & $\begin{array}{l}-0,058 \\
(0,102)\end{array}$ \\
\hline Turno: menos de 4 horas aula por dia & Base & Base & Base \\
\hline Turno: de 4 a 5 horas aula por dia & $\begin{array}{l}4,846^{* * *} \\
(0,679)\end{array}$ & $\begin{array}{l}2,373 \\
(1,709)\end{array}$ & $\begin{array}{l}0,021 \\
(1,646)\end{array}$ \\
\hline Turno: mais de 5 horas aula por dia & $\begin{array}{l}11,703 * * * \\
(2,230)\end{array}$ & $\begin{array}{l}10,884 * * \\
(4,377)\end{array}$ & $\begin{array}{l}8,474 \\
(5,830)\end{array}$ \\
\hline \multicolumn{4}{|l|}{ Escola } \\
\hline Região rural & $\begin{array}{l}-27,820 * * * \\
(5,315)\end{array}$ & & \\
\hline Biblioteca & $\begin{array}{l}-2,737 * * \\
(1,079)\end{array}$ & $\begin{array}{l}-2,018 \\
(1,954)\end{array}$ & $\begin{array}{l}-0,538 \\
(2,287)\end{array}$ \\
\hline Laboratório de informática & $\begin{array}{l}0,709 \\
(0,970)\end{array}$ & $\begin{array}{l}2,727 \\
(2,066)\end{array}$ & $\begin{array}{l}3,085 \\
(2,069)\end{array}$ \\
\hline Laboratório de ciências & $\begin{array}{l}3,154 * * * \\
(0,772)\end{array}$ & $\begin{array}{l}1,193 \\
(1,824)\end{array}$ & $\begin{array}{l}-0,528 \\
(2,018)\end{array}$ \\
\hline Quadra de esportes & $\begin{array}{l}2,780 * * * \\
(0,934)\end{array}$ & $\begin{array}{l}0,940 \\
(2,290)\end{array}$ & $\begin{array}{l}-2,208 \\
(2,102)\end{array}$ \\
\hline Internet & $\begin{array}{l}2,837 * * * \\
(0,798)\end{array}$ & $\begin{array}{l}0,149 \\
(1,574)\end{array}$ & $\begin{array}{l}-0,526 \\
(1,544)\end{array}$ \\
\hline Programa TV na escola & $\begin{array}{l}-3,389^{*} \\
(1,786)\end{array}$ & $\begin{array}{l}1,279 \\
(3,423)\end{array}$ & $\begin{array}{l}0,120 \\
(3,603)\end{array}$ \\
\hline
\end{tabular}




\begin{tabular}{|c|c|c|c|}
\hline Variáveis & $\begin{array}{l}\text { MQO agrupados } \\
\text { (dados de indivíduos) }\end{array}$ & $\begin{array}{l}\text { Efeitos Fixos } \\
\text { (dados de indivíduos) }\end{array}$ & $\begin{array}{l}\text { Efeitos Fixos } \\
\text { (dados de escola) }\end{array}$ \\
\hline Merenda & $\begin{array}{l}-4,923 * * * \\
(1,093)\end{array}$ & $\begin{array}{l}-1,081 \\
(2,113)\end{array}$ & $\begin{array}{l}1,887 \\
(2,730)\end{array}$ \\
\hline Professores no EF & $\begin{array}{l}0,197 * * * \\
(0,027)\end{array}$ & $\begin{array}{l}0,099 \\
(0,063)\end{array}$ & $\begin{array}{l}0,097 \\
(0,091)\end{array}$ \\
\hline Uso de computadores: & & & \\
\hline Para fins pedagógicos & $\begin{array}{l}3,409 * * * \\
(0,950)\end{array}$ & $\begin{array}{l}-0,594 \\
(1,689)\end{array}$ & $\begin{array}{l}-0,294 \\
(1,788)\end{array}$ \\
\hline Para uso em sala de aula & $\begin{array}{l}-2,203 * * \\
(0,990)\end{array}$ & $\begin{array}{l}1,732 \\
(1,923)\end{array}$ & $\begin{array}{l}0,926 \\
(2,271)\end{array}$ \\
\hline Para uso na administração & $\begin{array}{l}4,297 * * * \\
(0,834)\end{array}$ & $\begin{array}{l}-0,079 \\
(1,587)\end{array}$ & $\begin{array}{l}-0,981 \\
(1,584)\end{array}$ \\
\hline Turmas na $4^{\mathrm{a}}$ série diurnas & $\begin{array}{l}0,796^{*} \\
(0,454)\end{array}$ & $\begin{array}{l}-1,251 \\
(0,844)\end{array}$ & $\begin{array}{l}-1,335 \\
(1,205)\end{array}$ \\
\hline Turmas na $4^{\mathrm{a}}$ série noturnas & $\begin{array}{l}6,973 * * \\
(2,897)\end{array}$ & $\begin{array}{l}-1,103 \\
(7,348)\end{array}$ & $\begin{array}{l}-2,415 \\
(9,524)\end{array}$ \\
\hline Matrículas na 4a série & $\begin{array}{l}-0,032 * * \\
(0,014)\end{array}$ & $\begin{array}{l}-0,048 * * \\
(0,021)\end{array}$ & $\begin{array}{l}-0,043 \\
(0,032)\end{array}$ \\
\hline d_1997 & Base & Base & Base \\
\hline d_2001 & $\begin{array}{l}4,748^{* * * *} \\
(0,990)\end{array}$ & $\begin{array}{l}3,861 * * * \\
(1,320)\end{array}$ & $\begin{array}{l}1,575 \\
(1,518)\end{array}$ \\
\hline d_2003 & $\begin{array}{l}1,208 \\
(1,120)\end{array}$ & $\begin{array}{l}2,415 \\
(1,771)\end{array}$ & $\begin{array}{l}2,314 \\
(2,003)\end{array}$ \\
\hline d_2005 & $\begin{array}{l}6,517 * * * \\
(1,130)\end{array}$ & $\begin{array}{l}9,188 * * * \\
(1,843)\end{array}$ & $\begin{array}{l}7,776 * * * \\
(2,064)\end{array}$ \\
\hline Constante & $\begin{array}{l}166,871 * * * \\
(4,166)\end{array}$ & $\begin{array}{l}203,868 * * * \\
(6,062)\end{array}$ & $\begin{array}{l}219,352 * * * \\
(11,103)\end{array}$ \\
\hline Observações & 19.711 & 19.711 & 1.847 \\
\hline Grupos & & 913 & 913 \\
\hline R2 Within & & 0,0616 & 0,1506 \\
\hline R2 Between & & 0,2662 & 0,0869 \\
\hline R2 Total & 0,2014 & 0,0888 & 0,0787 \\
\hline Hausman & & $\begin{array}{l}\text { Chi } 2(52)=637,75 \\
\text { Prob }>\text { chi } 2=0,000\end{array}$ & $\begin{array}{l}\text { Chi } 2(52)=237,26 \\
\text { Prob }>\text { chi } 2=0,000\end{array}$ \\
\hline
\end{tabular}

Notas: (a) Desvios padrões ajustados para 913 "clusters" de escola.

Graus de significância: * $10 \% ; * * 5 \%, * * * 1 \%$.

\subsubsection{Resultados obtidos para as características dos alunos}

Pelos três modelos de regressão utilizados nos 4 painéis (Tabelas 10, 11, 12 e 13), os resultados mostram que os alunos do sexo masculino têm desempenho melhor nos testes de matemática do SAEB para a $4^{\mathrm{a}}$ série do que as meninas, pois os parâmetros estimados apresentam sinal positivo e significante a 1\% (à exceção das estimativas de Efeitos Fixos com médias de escolas nos painéis de 1999 a 2005, que não deram significantes). Nota-se que este efeito do sexo sobre o desempenho é mais forte nas escolas privadas do que nas públicas, e que este praticamente permanece inalterado depois de controlado o efeito fixo escola, havendo uma pequena diminuição nas escolas públicas e um aumento no caso das escolas privadas. A diferença entre o coeficiente de regressão dos meninos das escolas privadas e o 
coeficiente de regressão dos meninos das escolas públicas é estatisticamente significante ao nível de 0,05 .

Quanto ao atraso escolar, os parâmetros estimados para as variáveis "11 anos" e "12 ou mais anos" apresentam os sinais esperados (negativos) e a significância a 1\% em quase todas as estimações, tendo como idade de referência 9 anos, que seria a de um aluno adiantado um ano na série. No caso do aluno ter 10 anos de idade, a idade correta para a série, o sinal do parâmetro é positivo mas não significativo nas estimativas por Efeitos Fixos, e significativo a $1 \%$ e positivo nos casos das estimações de Efeitos Fixos para escolas públicas com dados de médias das escolas. À medida que aumenta o atraso escolar, os coeficientes estimados por EF com indivíduos apontam que há uma piora no rendimento dos alunos e, novamente, este efeito negativo do atraso escolar sobre o desempenho parece ser mais severo no caso dos alunos das escolas privadas (cerca de 10 pontos a menos nas notas relativamente ao efeito sobre as notas dos alunos da escola pública). A diferença entre os coeficientes de regressão por Efeitos Fixos da variável "12 ou mais anos" entre escolas públicas e privadas é estatisticamente significante a 0,05 . O controle por Efeitos Fixos diminui o efeito do atraso escolar sobre o desempenho nas escolas públicas, enquanto nas escolas privadas ele aumenta no caso do efeito da variável "11 anos" e diminui no caso da variável "12 ou mais anos".

Quanto ao coeficiente obtido nas estimações de Efeitos Fixos relacionado à raça declarada pelo aluno, o coeficiente de "pardos ou mulatos" apresentou sinal positivo e significativo a $1 \%$ e $5 \%$ para as estimações com dados de indivíduos e escolas, respectivamente, mas apenas nas estimações feitas com escolas públicas (no painel longo e no mais curto). Além disso, nas escolas públicas este coeficiente aumenta e muda de sinal quando se inclui o efeito escola na estimação. Para o aluno que se declara de raça "negra", por sua vez, o coeficiente é significativo a $1 \%$ e negativo nas estimações por mínimos quadrados agrupados e Efeito Fixo com indivíduos tanto nas escolas públicas quanto nas privadas. Porém, vale ressaltar que nas escolas privadas ele é mais negativo (quase chegando a ser o dobro) dos coeficientes obtidos para escolas públicas. Esta diferença entre os coeficientes estimados para os alunos das escolas privadas e públicas é significativamente diferente de zero a 5\%. A inclusão do Efeito Fixo atenua um pouco o impacto desta variável nos dois tipos de escolas. 

dos alunos

Como mostram as estimações de Efeitos Fixos com dados de indivíduos, o fato de o aluno ter computador em casa apresentou significância a 10\% apenas no caso de alunos de escolas privadas no painel mais longo (1997-2005).

No que diz respeito ao ambiente familiar, a variável "mora com pai e mãe" apresentou sinal positivo e significante a 1\% e 5\% nas estimações por Efeitos Fixos para escolas privadas e públicas, respectivamente, com dados de indivíduos. O coeficiente de Efeitos Fixos com dados de indivíduos é maior (da ordem de 5,02 no painel mais longo e 5,00 no painel mais curto) e mais significativo (1\%) nas escolas privadas do que os obtidos nas estimações com escolas públicas (da ordem de 0,86 no painel mais longo e 1,05 no painel mais curto, significantes a 5\%) e esta diferença é significativamente diferente de zero ao nível de confiança de 5\%. A inclusão do efeito escola específico nas estimações reduz o coeficiente estimado para esta variável, tanto nas escolas públicas quanto nas particulares, em relação às estimações de MQO agrupados.

Indo ao encontro do que a literatura e outros trabalhos no mesmo gênero reportam ${ }^{12}$, os coeficientes nas estimações de Efeitos Fixos com dados de indivíduos sobre os nível educacional da mãe se mostraram quase todos significantes e com o sinal positivo. Porém, há algumas diferenças nos resultados obtidos com escolas públicas e com escolas privadas.

Nas escolas privadas o fato de a mãe ter feito apenas o ensino primário (de $1^{\mathrm{a}}$ à $4^{\mathrm{a}}$ série) só apresentou significância no painel mais longo a 10\%, enquanto nas escolas públicas os resultados obtidos para esta variável são todos significativos a 1\%. Além disso, pela magnitude dos coeficientes nas estimações de Efeitos Fixos com dados de indivíduos, os alunos de escolas privadas se beneficiam mais do nível educacional da mãe do que os alunos das escolas públicas, enquanto se observa apenas uma pequena redução na importância desses coeficientes quando se inclui na regressão o efeito fixo de escola. A relação condicional positiva entre o estudo da mãe e o desempenho do aluno cresce à medida que o nível educacional da mãe aumenta, principalmente no caso das escolas privadas.

\footnotetext{
${ }^{12}$ Ver, por exemplo, Menezes-Filho (2007), Felício e Fernandes (2006).
} 
Por fim, no painel mais curto, tanto nas estimações para escolas privadas quanto para as públicas, o coeficiente da variável "aluno trabalha fora" apresentou sinal negativo e altamente significante $(1 \%)$ nas estimações por MQO agrupados e Efeitos Fixos com dados de indivíduos. Nas estimações com as médias por escolas, apenas nas escolas privadas o coeficiente apresentou significância a 5\% e seu sinal também deu negativo. Os alunos das escolas particulares parecem sofrer mais prejuízo em seu aprendizado quando trabalham fora do que os alunos das escolas públicas. Com dados de indivíduos, o coeficiente de "aluno trabalha fora" é da ordem de -12 nas escolas privadas, e de $-7,12$ nas escolas públicas, e esta diferença é significativamente diferente de zero ao nível de confiança de 5\%.

\subsubsection{Resultados obtidos para as características dos professores}

Quanto aos efeitos de algumas características observáveis dos professores (Tabelas 10, 11, 12 e 13), os resultados das se mostraram todos não significativos quando é incluído o efeito escola-específico na regressão. Porém, nas estimações por MQO agrupados com dados de escolas públicas, o fato do professor ser do sexo masculino apresentou sinal negativo e significância a $1 \%$. Além disso, o fato do professor ter ensino superior apresentou sinal positivo e magnitude de 3,75 nos dois painéis e, por fim, a idade do professor "40 ou mais anos" apresentou sinal positivo e significância a 5\% mas apenas no painel mais longo (19972005).

Nas estimações por MQO agrupados com dados de escolas privadas, as variáveis de professor "ter ensino superior" e "ter 40 ou mais anos" também apresentaram significância a 1\% e 5\%, respectivamente. Além disso, o fato do professor lecionar há mais de 15 anos também se mostrou significante a $1 \%$ nos dois painéis estimados por MQO agrupados com dados de escolas privadas. Ainda referindo-se a este caso, outros resultados significantes, mas menos robustos, foram o efeito positivo do professor ter entre 30 e 40 anos (sinal positivo e significativo a $5 \%$ apenas no painel mais curto), e o fato do professor ter feito curso de capacitação (sinal positivo e significante a $10 \%$ apenas no painel mais longo).

No que diz respeito ao nível educacional do professor, os resultados só se mostraram altamente significativos e positivos nas estimações por MQO. De acordo com o que defende Hanuschek (2005), o nível educacional do professor e demais características observáveis, como experiência e capacitação, não captam a qualidade do professor, isto é, não espelham se o professor é capaz de agregar maior aprendizado aos seus alunos. Neste caso, os coeficientes 
obtidos por MQO agrupados para essas variáveis estariam refletindo apenas relações espúrias. Porém, é possível argumentar que o nível educacional do professor exerce influência positiva sobre o aprendizado dos alunos, mas que o método de Efeitos Fixos inclui no termo escolaespecífico não observado muita informação, inclusive sobre o efeito fixo não-observado da qualidade do professor, que pode estar correlacionado com a sua educação, mas que inclui outras características não observáveis. Por exemplo, as escolas tem processos de escolha dos professores que tomam por base o nível educacional dos mesmos, bem como uma série de outras informações como habilidade, histórico profissional, relações de amizade ou "quem indique" e, portanto, tudo isto pode estar sendo captado pelo efeito específico da escola nas regressões por Efeitos Fixos.

\subsubsection{Resultados obtidos para as características dos diretores}

No questionário dos diretores avaliados pelo SAEB, em se tratando do painel mais curto (1999-2005), há a pergunta se houve "problema com professores faltosos". Nas estimações de MQO, tanto para escolas quanto para as privadas, o efeito desta variável apresentou sinal negativo e significante a 5\% e 1\%, respectivamente. Já nas estimações por Efeitos Fixos o coeficiente desta variável não se mostrou significativo, novamente talvez porque seu efeito esteja sendo captado pelo efeito específico da escola.

Nas escolas privadas, a única característica observável dos diretores que apresentou sinal negativo e significância de 5\%, nas estimações por Efeitos Fixos com dados de indivíduos e dados de escola, foi o fato do diretor "exercer a função há mais de 10 anos". Já nas estimações de Efeitos Fixos com dados de indivíduos, nas escolas em que "o projeto pedagógico foi desenvolvido pelo diretor e professores", e não pela Secretaria de Educação, apresentou um coeficiente com sinal negativo e significante a $5 \%$, no painel mais longo, e a $10 \%$ no painel mais curto. A variável "assumiu o cargo por indicação ou outras formas" apresentou parâmetro com sinal negativo e significativo a $10 \%$, mas apenas na estimação com o painel mais curto. No que diz respeito às características dos diretores em escolas públicas, nenhuma delas se mostrou significativa nas estimações de Efeitos Fixos.

\subsubsection{Resultados obtidos para as características das turmas}

No painel mais curto, de 1999 a 2005, foi possível incluir variáveis com características das turmas dos alunos que fizeram a prova do SAEB. Tanto nas estimações com as escolas 
privadas quanto nas com escolas públicas, as estimações com Efeitos Fixos, em geral, não deram resultado significativo, como é descrito a seguir:

Nas escolas privadas, o coeficiente da variável que indica que as turmas têm mais de 5 horasaula por dia deu positivo e significante à $1 \%$ tanto na estimação por MQO agrupados (coeficiente igual a 11,7) quanto na estimação por Efeitos Fixos (coeficiente igual a 10,88). Nenhum outro resultado por Efeitos Fixos deu significativo no caso das escolas privadas. Porém, nas estimações com MQO, os parâmetros mostram alguns resultados interessantes.

O fato da turma ter tido "apenas um professor de matemática no ano", o que se traduz em baixa rotatividade de professores, apresentou sinal positivo e significativo a $1 \%$, e a variável "tamanho médio das turmas", apresentou sinal negativo e significante a 1\%. Além destas, o fato da turma ter "entre 4 e 5 horas-aula por dia" apresentou significância a 1\% e parâmetro positivo igual a 4,85 . Vale notar que o mesmo sinal permanece nos resultados das estimações com Efeitos Fixos para estas variáveis, embora haja sempre uma diminuição em sua magnitude e estes deixem de ser significantes. Mais uma vez, acredita-se que o Efeito Fixo de escola, nestes casos, já esteja captando os efeitos dessas características das turmas, e por isso eles deixem de ser significantes nas estimações por Efeitos Fixos. No caso das escolas públicas, não houve nenhuma resultado significante pelo método de efeitos fixos. No entanto, por MQO, todas as variáveis de turma apresentaram efeitos significantes entre $1 \%$ e $10 \%$.

\subsubsection{Resultados obtidos para as características das escolas}

No que diz respeito aos efeitos das características das escolas, nas escolas privadas o único efeito que se mostrou significativo nos três modelos estimados no painel mais longo foi o de "número de matrículas na 4a série", que apresentou sinal negativo e significância a 1\% nas estimações com indivíduos (MQO agrupados e Efeitos Fixos) e a 10\% na estimação por Efeitos Fixos com médias de escolas. No painel mais curto, ainda no caso das escolas privadas, apenas as estimações com dados de indivíduos (MQO agrupados e Efeitos Fixos) se mostraram significantes a 5\%. Este pode ser um indício de que há um efeito escala negativo a partir de determinado ponto nas escolas privadas, em que os recursos por alunos matriculados na série em questão se tornam mais escassos. Vale notar, porém, que a magnitude destes coeficientes é bem pequena, ficando entre 0,011 e 0,028 apenas.

Quanto às estimações com escolas públicas e dados do painel mais curto (1999-2005), o fato da escola se situar na região rural apresentou um sinal negativo na estimação por MQO 
agrupados, resultado já encontrado na literatura nacional sobre o tema. Nas estimações por Efeitos Fixos, os efeitos de a escola ter "biblioteca", participar do programa do MEC "TV na Escola" e ter computadores para "uso na administração" apresentaram sinais negativos e significância a 10\%, 5\% e 10\%, respectivamente. Isto pode decorrer do problema de "causalidade reversa" nas variáveis. Por exemplo, exatamente nas escolas que apresentavam um desempenho ruim, o governo tenha realizado investimentos em bibliotecas, compra de computadores e inclusão da escola em programas educacionais para tentar reverter o mal desempenho. É possível que se tenha captado nas estimações exatamente um ponto na curva da qualidade da escola decrescente, em que tais políticas de insumo foram implementadas. Ainda no que diz respeito às estimações com escolas públicas e dados do painel mais curto, a variável "matrículas na quarta série" apresentou sinal negativo e significativo a 5\%, mas apenas na estimação por Efeitos Fixos com médias de escolas.

\subsection{Comentários finais}

Neste estudo foi possível captar o efeito diferenciado que as variáveis que entraram na função de produção de educação exercem sobre o aprendizado dos alunos das escolas públicas e os alunos das escolas privadas. Em primeiro lugar, as características dos alunos e suas famílias em geral apresentaram uma importância maior no desempenho escolar dos alunos das escolas particulares do que no desempenho dos alunos da redes públicas de ensino (escolas estaduais e municipais). Os alunos do sexo masculino apresentaram um desempenho melhor nas provas de matemática do que as meninas em todas as estimações. Porém, este efeito é mais importante nas escolas privadas, onde os alunos homens tendem ter até 6,96 pontos de vantagem nas notas em relação às colegas do sexo feminino, enquanto nas escolas públicas esta vantagem chega a ser de 4,79 pontos (ver terceira coluna das Tabelas 11 e 13). Esta diferença entre o coeficiente de regressão dos meninos das escolas privadas e o coeficiente de regressão dos meninos das escolas públicas é estatisticamente significante ao nível de 0,05.

O atraso escolar é outro exemplo no mesmo sentido, pois as estimações indicam que seus efeitos são mais severos sobre o desempenho dos alunos das escolas privadas do que sobre os das escolas públicas, com uma diferença entre os coeficientes de regressão estatisticamente significante a 0,05 em se tratando dos alunos atrasados dois anos na série (12 anos). Seria isto um indicador de melhor ou pior qualidade nas escolas particulares? Talvez as escolas 
particulares sejam menos severas do que as escolas públicas na hora de avaliar se o aluno adquiriu os conhecimentos necessários para evoluir de série, deixando pra trás apenas aqueles que se saem realmente muito mal. Porém, dado que o desempenho das escolas privadas é, em média, bem melhor do que das escolas públicas (ver Tabela 5), isto pode também indicar que nas escolas privadas os alunos conseguem aprender mais do que nas escolas públicas, ficando para trás alunos que, se avaliados numa escola pública, tenderiam a ser aprovados.

O fato de ter computador em casa parece ajudar no desempenho dos alunos das escolas particulares. Seu coeficiente se mostrou significativo a $10 \%$ mas apenas na estimação com dados do painel 1997-2005 (ver Tabela 11).

No que diz respeito a raça declarada pelo aluno, aqueles das escolas públicas que se declaram "pardos ou mulatos" têm um desempenho melhor que os que se declaram brancos. Este efeito não se confirma nas regressões com escolas privadas, pois neste caso o coeficiente não deu significativo. Em se tratando dos alunos da raça "negra", estes apresentam um desempenho pior tanto nas escolas públicas quanto nas privadas. Porém, o efeito negativo desta variável é bem mais forte nas escolas privadas do que nas públicas: nas escolas privadas os negros tendem a pontuar até $-13,783$ pontos (Tabela 13) em relação aos brancos, enquanto nas escolas públicas tendem a pontuar até $-6,590$ pontos (Tabela 12) em relação aos seus colegas brancos. Esta diferença entre os coeficientes dos alunos negros das escolas privadas e das públicas é significativamente diferente de zero a 5\% de grau de significância.

O fato de o aluno morar com o pai e a mãe também apresentou um coeficiente positivo e significante a $1 \%$ nas estimações por MQO agrupados e Efeitos Fixos com dados de indivíduos. Mais uma vez os alunos das escolas privadas se beneficiam mais desta condição familiar do que os alunos das escolas públicas, pois a diferença entre os coeficientes estimados para os alunos das escolas privadas e os alunos das escolas públicas é estatisticamente diferente de zero a 5\% de grau de significância.

Indo ao encontro da literatura sobre o tema, a escolaridade da mãe contribui para um melhor desempenho dos alunos nas provas. Em relação à mãe nunca ter estudado, nas escolas públicas o fato da mãe ter feito o primeiro ciclo do ensino primário $\left(1^{\mathrm{a}}\right.$ a $4^{\mathrm{a}}$ série$)$ aumenta em 2,66 pontos a nota do aluno, segundo as estimativas com Efeitos Fixos com dados de indivíduos. Já nas escolas privadas este nível educacional das mães não apresentou 
significância, já que há relativamente poucas mães de alunos de escolas privadas com este grau de instrução (ver Tabela 5) . A partir do nível de educação da mãe "ensino médio", os alunos das escolas privadas conseguem tirar maior proveito da educação de suas mães. A diferença entre os coeficientes estimados para o caso da mãe ter feito "ensino médio" ou "faculdade" entre os alunos de escolas privadas e públicas é significativamente diferente de zero a 5\% de grau de significância.

Nenhuma efeito das características observáveis dos professores foi captado nas estimações por Efeitos Fixos, e o mesmo vale para as características das turmas e diretores no caso das escolas públicas. Quanto às variáveis relativas ao diretor nas escolas privadas, alguns coeficientes se mostraram significativos nas estimações por Efeito Fixo. Os mais robustos foram os coeficientes das variáveis "diretor exerce a função há mais de 10 anos", cujo efeito se mostrou negativo, e quando “ o projeto pedagógico foi desenvolvido pelo diretor e professores", cujo efeito também se mostrou negativo relativamente à escola adotar o projeto pedagógico da Secretaria da Educação (Tabelas 11 e 13).

Por fim, poucas variáveis de escola apresentaram coeficientes significativamente diferentes de zero nas estimações por Efeitos Fixos. As escolas privadas com "turno maior que 5 horasaula" apresentam melhor desempenho segundo as estimações por Efeitos Fixos, enquanto que o "numero de matrículas na $4^{\mathrm{a}}$ série" piora o desempenho. Nas escolas públicas, por sua vez, as estimações por Efeitos Fixos indicaram que o fato da escola possuir "biblioteca", participar do programa "TV na Escola" do MEC e ter computadores "para uso na administração" pioram o desempenho dos alunos. Como dito anteriormente, neste caso pode estar havendo o problema da causalidade reversa entre as variáveis: exatamente porque as escolas estão indo mal, o governo decide implementar tais políticas de insumos visando a melhoria da qualidade do ensino no futuro. Por fim, o número de "matrículas na $4^{\mathrm{a}}$ série" também parece exercer nas escolas públicas um efeito negativo sobre a qualidade do ensino, provavelmente decorrente de uma maior escassez de recursos por aluno.

O que se pôde observar até aqui é que apenas algumas variáveis se mostram altamente significativas, independentemente do ano e da extensão do painel utilizado, e que essas variáveis se resumem praticamente às características dos alunos, o seu atraso escolar, e ao status socioeconômico de suas famílias. Esperava-se que, por se trabalhar com um painel de dados com um número maior de anos, fosse possível captar melhor a influência que 
características observáveis das escolas, diretores, turmas e professores exercem sobre a proficiência dos alunos, principalmente através do modelo Efeitos Fixos que controla as características não observáveis específicas de cada escola e constantes no tempo. Isto poderia ser muito importante em termos de recomendações de políticas para melhorar a qualidade do ensino no país bem como a qualidade dos gastos públicos na educação.

Esta expectativa, porém, não se comprovou nas análises acima realizadas. Porém, duas recomendações de políticas educacionais importantes emergem dos resultados aqui encontrados. A primeira delas é de que um turno superior a 5 horas-aula pode aumentar o aprendizado dos alunos nas escolas públicas (dado que o percentual deste tipo de escola pública, que adota um turno de 5 ou mais horas-aula, é muito pequeno como mostra a Tabela 9). Uma segunda recomendação de política seria a de garantir uma taxa de insumo por aluno adequada, uma vez que parece haver um efeito escala negativo quando aumenta muito o número de matrículas na quarta série, tanto nas escolas públicas quanto nas privadas. Estas são duas recomendações de políticas que, sozinhas e se atendidas, exigiriam gastos substanciais na área de educação

A maioria das variáveis que nesta análise se mostraram determinantes para o aprendizado não estão diretamente associadas à políticas de educação, à exceção dos dois resultados apontados acima como o turno escolar e o número de alunos matriculados na série. Esta constatação vai ao encontro do que Hanushek (Op.cit) e que parte da literatura internacional sobre o tema defendem: de que as características que fazem uma boa escola, um bom professor ou um bom diretor, não são passíveis de mensuração, e não se explicam por características observáveis, tais como os anos de escolaridade, a idade ou seus anos de experiência.

Por outro lado, talvez o método de estimação não seja o adequado para se medir o impacto das variáveis regressoras de interesse, como defendido por Lee (Op cit). Será que o uso de modelos hierárquicos traria resultados diferentes? Por enquanto, a única conclusão que os resultados nos permitem inferir é que as condições socioeconômicas dos alunos e suas famílias são as grandes responsáveis pelo desempenho dos alunos no caso aqui estudado (alunos da $4^{\mathrm{a}}$ série avaliados nas provas de matemática), e que a estratificação social que existe no país replica-se no sistema educacional. Este, por sua vez, não consegue quebrar as barreiras da estratificação, tornando-se mais uma força no sentido da reprodução da desigualdade. 


\section{DO SAEB}

\subsection{Introdução}

Existe uma preocupação crescente com a "responsabilidade" atribuída à escola e educadores no processo de aprendizado. O Chile, e os Estados Unidos são exemplos de países em que o desempenho das escolas em testes padronizados é utilizado pelo governo para nortear a alocação de recursos, recompensas, sanções e assistência às escolas. Também o Brasil caminha no sentido de desenhar mecanismos de incentivos que tomam como base os resultados que emergem de avaliações em testes padronizados para nortear políticas de "responsabilização". Recentemente, porém, alguns artigos chamaram a atenção para a existência de ruídos nas informações sobre qualidade das escolas a partir do desempenho dos alunos em testes padronizados, que podem prejudicar o correto entendimento do significado dos rankings e índices de desempenho.

No Brasil há uma preocupação por parte da sociedade e dos elaboradores de políticas educacionais de melhorar a qualidade do ensino através da atribuição de "metas" educacionais a serem alcançadas pelas escolas. Isto exige que indicadores confiáveis de desempenho sirvam de parâmetro para as políticas de incentivo, quando o objetivo é premiar, punir ou auxiliar aquelas que são ou não capazes de atingir o desempenho esperado. Para a implementação de tais políticas, têm sido propostos alguns indicadores de qualidade educacional com base no desempenho dos alunos em exames padronizados, como o Sistema Nacional de Avaliação da Educação Básica (SAEB), a Prova Brasil e os resultados do programa internacional de avaliação de alunos conhecido como PISA (Programme for International Student Assessment).

O Índice de Desenvolvimento da Educação Básica (IDEB), proposto pelo Instituto Nacional de Pesquisas e Estudos Educacionais Anísio Teixeira (INEP), é um exemplo de indicador de qualidade educacional obtido por uma combinação de informações sobre desempenho em exames padronizados (Prova Brasil ou SAEB, ao final da $4^{\mathrm{a}}$ e $8^{\mathrm{a}}$ séries do ensino fundamental e da $3^{\mathrm{a}}$ série do ensino médio) e de rendimento escolar (nível de aprovação nas escolas). $\mathrm{O}$ IDEB pode servir para o governo monitorar as redes de ensino e exigir contrapartidas de 
desempenho das escolas, em termos de um avanço esperado no indicador, quando da liberalização de recursos (para maiores detalhes ver INEP, 2008 e Fernandes, 2008).

O governo do Estado de São Paulo também tem buscado meios de aperfeiçoar o monitoramento das escolas estaduais paulistas. A partir da definição de uma métrica nos moldes do IDEB, pretende-se estabelecer metas a serem atingidas pelas escolas ao longo dos anos. O sucesso das escolas no cumprimento das metas servirá de parâmetro para a concessão de incentivos a todos os funcionários das escolas. A sociedade civil também tem se manifestado a respeito, como o movimento da sociedade civil denominado "Compromisso Todos Pela Educação", que propõe valores de desempenho escolar acima dos quais devem estar 70\% dos alunos brasileiros até 2022 (MENEZES-FILHO et al., 2008).

É questão já amplamente conhecida por pesquisadores e estudiosos da área que os rankings puros (que tomam por base o desempenho médio dos alunos nos testes padronizados) refletem principalmente o status socioeconômico (SSE) dos alunos das escolas. Por isso, tal tipo de ranking não é adequado para nortear políticas de incentivos e responsabilização, pois, neste caso, diretores e professores estariam sendo recompensados (ou "punidos") pelo tipo de aluno que servem, e não pelo quanto conseguem fazer com que seus alunos aprendam mais. Também não é desejável que haja muita volatilidade nos rankings de uma avaliação para a outra , uma vez que isso confunde os agentes e os fazem rever a cada período as suas escolhas e políticas.

Alguns estudos para o caso do Chile apontam novas questões quanto à confiabilidade dos resultados obtidos com diferentes medidas utilizadas para a construção de rankings de escolas, inclusive as que contam com controles para o status socioeconômico (SSE) dos alunos. Suas advertências serviram de estímulo para que neste trabalho se buscasse averiguar se os resultados encontrados para o Chile se estendem para o caso do sistema educacional brasileiro. É preciso saber até que ponto os rankings de escolas que resultam de avaliações como o SAEB ou Prova Brasil, após ser feito ou não o controle por características socioeconômicas dos alunos, são confiáveis no sentido de servirem de parâmetro para pais, educadores e formuladores de política sobre quais escolas realmente agregam mais valor ao aprendizado. 
Além desta introdução, o trabalho está organizado da seguinte forma: a seção 2 traz a discussão sobre o tema encontrado na literatura, a seção 3 apresenta os dados utilizados neste trabalho e algumas estatísticas descritivas, a seção 4 apresenta a metodologia utilizada, a seção 5 traz os resultados e a seção 6 apresenta os comentários finais.

\subsection{Referencial teórico}

Para se estimar melhor a qualidade ou o valor adicionado pelas escolas, geralmente acompanha-se o progresso do aluno ao longo de vários anos, e utilizam-se informações sobre seu status socioeconômico (SSE) e outras informações disponíveis com respeito, por exemplo, à escola em que estuda.

Os desafios neste campo de investigação são muitos. Primeiramente, a maioria dos países em desenvolvimento não conta com um sistema de avaliação da qualidade na educação que permita acompanhar o progresso de cada aluno ao longo dos anos de escola. Além disso, muitas das variáveis de famílias, alunos e mesmo escolas não são observadas pelos pesquisadores. Esta omissão tende a viesar as estimativas do efeito-escola. Um outro problema, constatado por exemplo por Mcewan e Urquiola (2005), é que o controle por SSE, principalmente num sistema de escolas com elevada estratificação, vem ao custo de introduzir muita volatilidade nos rankings de notas das escolas.

Segundo Mizala et al. (2007), existe, pelo menos no caso do Chile, um "trade-off" entre construir rankings de escolas que não espelhem majoritariamente a condição socioeconômica de seus alunos e, por outro lado, não apresentem muita volatilidade de um ano ao outro. Rankings que espelham majoritariamente o SSE de alunos não são adequados para se nortear políticas de inventivos e responsabilização, pois, neste caso, diretores e professores estariam sendo recompensados (ou "punidos") pelo tipo de aluno que servem, e não pelo quanto conseguem fazer com que aprendam mais. Uma alta volatilidade nos rankings de uma avaliação a outra também não é desejável, uma vez que confunde os agentes e os fazem rever a cada período as suas escolhas e políticas. Por exemplo, qualquer mecanismo de incentivo que os elaboradores de política de educação implementem, tomando como referência rankings voláteis, acabam tornando-se ineficazes ou inócuos, pois logo os agentes deixam de responder 
a recompensas e punições cujas distribuições se aproximem daquelas geradas por um processo de "loteria".

A volatilidade pode ocorrer devido a eventos em apenas um momento do tempo, como o advento de doenças que atingem toda a escola, distração de alunos e responsáveis no dia de realização das provas e assim por diante. Outra razão para volatilidade é a variação nas amostras. Cada coorte de alunos que entra na escola é como uma amostra aleatória de uma população local e, portanto, a média de desempenho da escola vai variar de acordo com o grupo específico de alunos que começou a estudar num determinado ano. A sua variância, por sua vez, dependerá da variabilidade de desempenho na população da qual a escola recebe os alunos, e também do número de alunos avaliados (ver CHAY et al., p. 1242-1244).

\subsection{Dados e estatísticas descritivas}

Os dados utilizados nas análises que se seguem provêm do SAEB. O SAEB é um levantamento bianual realizado pelo INEP desde 1993 que avalia os alunos da $4^{\mathrm{a}}$ e $8^{\mathrm{a}}$ série do ensino fundamental, e da $3^{\text {a }}$ série do Segundo grau, nas disciplinas de matemática e língua portuguesa. Seus levantamentos também trazem informações socioeconômicas sobre os alunos e suas famílias, professores e diretores, além de informações sobre a infra-estrutura nas escolas. Os levantamentos do SAEB são amostras representativas da população de escolas no Brasil. A subamostra aqui utilizada se restringe a 480 escolas que se repetem nas avaliações de 1999, 2001 e 2003, formando um painel de escolas balanceado de três anos. Serão utilizados os resultados das provas de português e matemática dos alunos na $4^{\mathrm{a}}$ série do ensino fundamental para se construir os rankings de escolas. O número de alunos avaliados em 1999, 2001 e 2003 é de 5.819, 13.629 e 13.114, respectivamente. A Tabela 14 traz a evolução do número de matrículas na $4^{\mathrm{a}}$ série nas 480 escolas avaliadas no SAEB nos anos de 1999, 2001 e $2003^{13}$.

\footnotetext{
${ }^{13}$ Em alguns anos não se tem informações sobre o número de matrículas de algumas escolas no Censo Escolar , provavelmente devido a erros na computação dos dados. Em 1999, 30,35\% das escolas da amostra não têm dados sobre matrículas na $4^{\mathrm{a}}$ série (matrículas são iguais à zero), em 2001 essa porcentagem é de $1,80 \%$, e em 2003 é de $16,15 \%$. No total, $12,68 \%$ da amostra de escolas, considerando-se os três anos, não apresentam dados sobre matrículas. Estas escolas, porém, foram mantidas na análise, uma vez que o número de matrículas não foi utilizado para a construção dos rankings.
} 
Tabela 14- Matrículas na $4^{a}$ série e sua evolução, por escola, na amostra de 480 escolas avaliadas pelo SAEB em 1999, 2001 e 2003

\begin{tabular}{ccccccc}
\hline Variável & Média & $\begin{array}{c}\text { Desvio- } \\
\text { Padrão }\end{array}$ & Mínimo & Máximo & Observações \\
\hline Matrículas na 4a. Série & Total & 84,28 & 69,40 & 1,00 & 589,00 & $\mathrm{~N}=28.432$ \\
& Between & & 50,39 & 5,00 & 459,79 & $\mathrm{n}=480$ \\
& Within & & 29,28 & $-47,62$ & 231,66 & \\
\hline
\end{tabular}

A Figura 1 mostra a relação entre o número de matrículas na quarta série em cada escola avaliada em 2001 e o número de alunos que fizeram as provas de matemática e português do SAEB neste mesmo ano ${ }^{14}$.

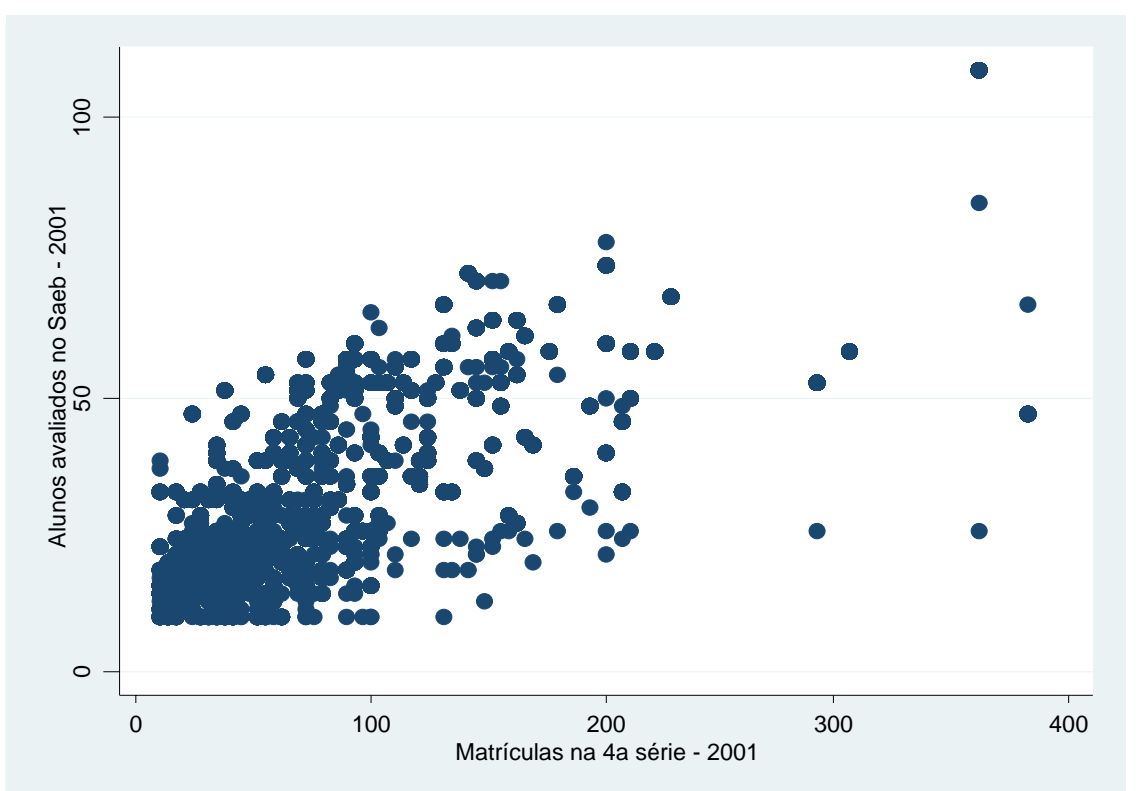

FIGURA 1 - Número de alunos matriculados na $4^{\text {a }}$ série em cada escola em 2001 e número de alunos da $4^{\mathrm{a}}$ série avaliados nas provas do SAEB de português e matemática nas mesmas escolas em 2001.

Fonte: cálculos a partir das notas em matemática em 480 escolas que se repetem nos anos de 1999, 2001 e 2003 do SAEB e que apresentam dados sobre matrículas no Censo Escolar.

Na Figura 2 pode-se ter uma idéia de quanto varia o desempenho médio dos alunos nas provas de matemática e português de acordo com o tamanho da escola, medido pelo total de alunos matriculados na $4^{\mathrm{a}}$ série. Percebe-se uma maior variabilidade na pontuação média das escolas menores, de acordo com o que foi observado para caso do Chile por Mcewan et al. (2007).

\footnotetext{
${ }^{14} \mathrm{O}$ mesmo padrão de gráfico se repete quando se consideram os anos de 2001 e 2003 e, seus respectivos gráficos não são aqui reportados.
} 


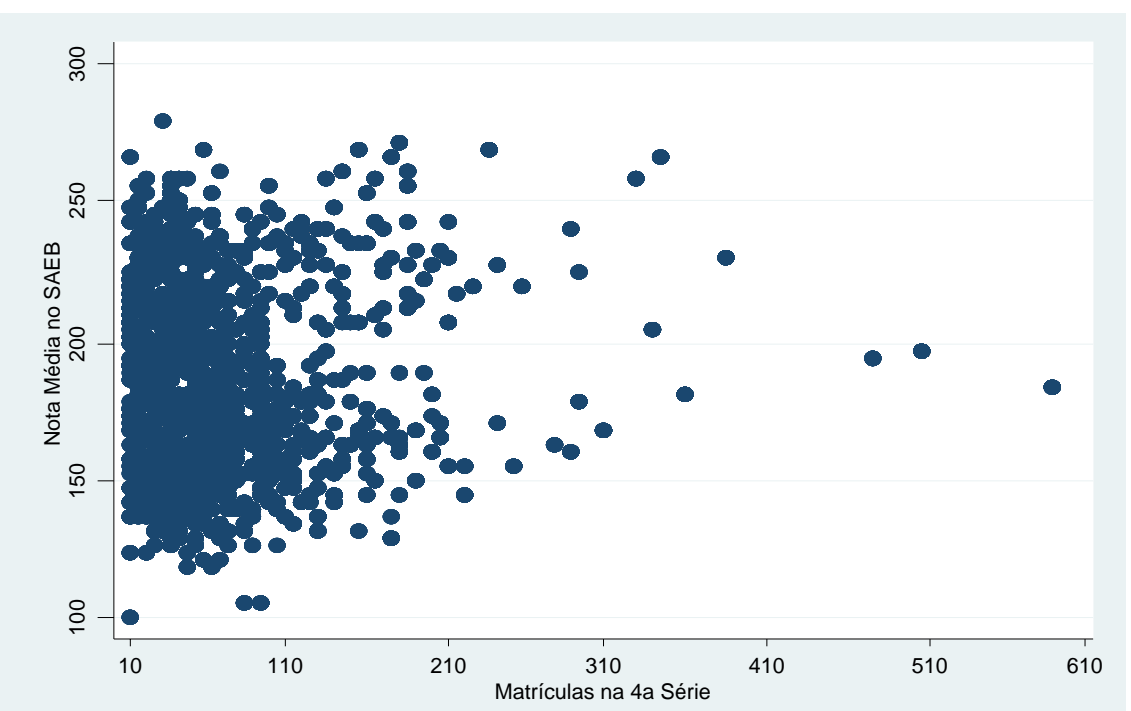

FIGURA 2 - Desempenho da escola e tamanho da escola, medidos pelas notas em matemática e português no SAEB e número de matrículas na 4a série.

Fonte: cálculos a partir das notas em matemática em 480 escolas que se repetem nos anos de 1999, 2001 e 2003 do SAEB e apresentam dados sobre matrículas.

Mas é quando se considera a diferença na proficiência média obtida em diferentes anos que se pode observar uma variância mais acentuada no caso das escolas pequenas. A Figura 3 mostra a relação entre a diferença na proficiência média das escolas (em matemática e português), medida entre os anos 1999-2001, e o tamanho da escola medido pelo número de alunos matriculados na $4^{\text {a }}$ série $^{15}$.

\footnotetext{
${ }^{15}$ Para o cálculo da diferença na proficiência, foram utilizados os dados apenas das 480 escolas que se repetem nos anos 1999, 2001 e 2003. Os gráficos das diferenças 2003-2001 e 2003-1999 não foram reportados por apresentarem padrão muito similar ao observado na Figura 2.
} 


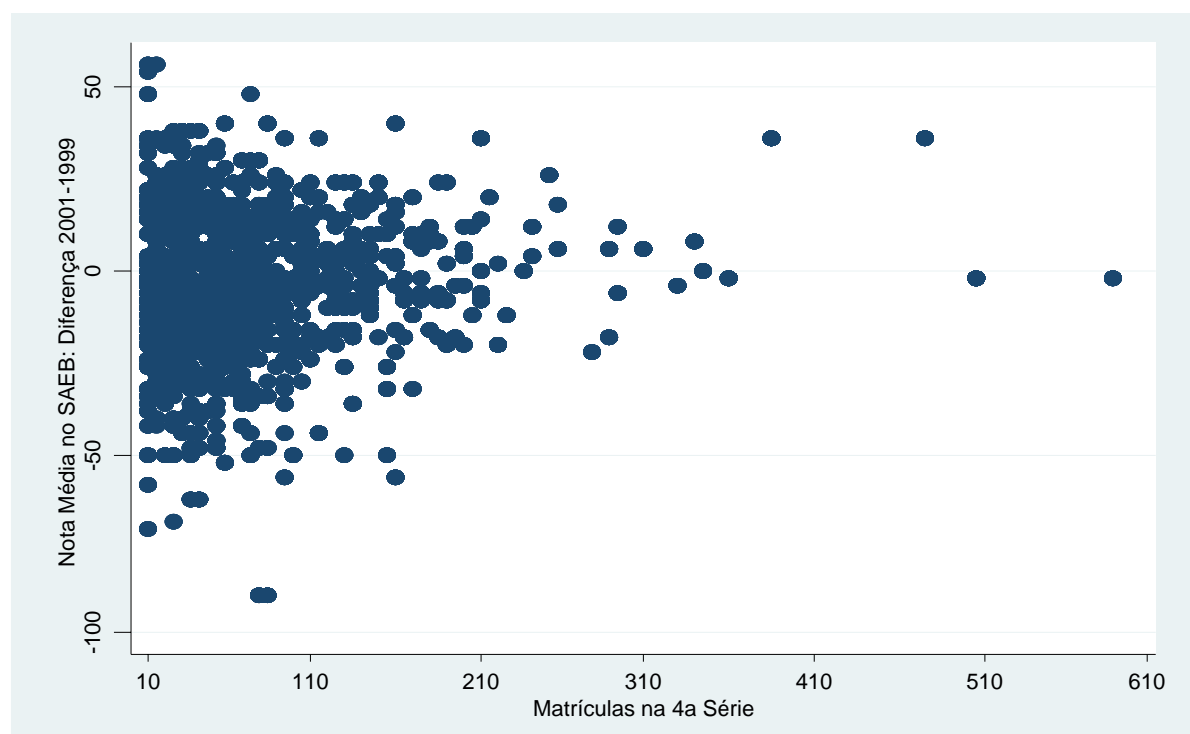

FIGURA 3 Diferenças nas notas médias das escolas (2001-1999) e tamanho da escola, medidos pelas notas em matemática e português no SAEB e número de matrículas na 4a série.

Fonte: cálculos a partir das notas em matemática em 480 escolas que se repetem nos anos de 1999, 2001 e 2003 do SAEB e apresentam dados sobre matrículas.

As figuras 2 e 3 sugerem indícios de ocorrência do fenômeno de "reversão para a média" para o qual Mizala et al. (Op. cit), Chay et al. (Op. cit) e Mcewan et al. (Op. cit) chamam a atenção no Chile. Nas escolas menores, haveria a tendência dos resultados de desempenho variarem muito de um momento de avaliação para outro. Escolas que se saem muito mal em um primeiro momento tendem a apresentar, numa avaliação seguinte, uma recuperação, enquanto que as que se saem bem em seguida tendem a apresentar um resultado bem pior. Os autores demonstram que este efeito é maior quanto menor o número de alunos avaliados ${ }^{16}$.

Outro fator que contribui para a volatilidade nos rankings de escolas é a elevada estratificação por renda nas mesmas. A Figura 4 mostra a relação entre desempenho médio da escola nas avaliações de português e matemática na $4^{\mathrm{a}}$ série e a proporção de mães com ensino superior na escola, uma variável proxy para indicar um elevado SSE dos alunos da escola que fizeram a avaliação. Nota-se claramente uma relação positiva, o que é forte indício de elevada estratificação social no sistema educacional brasileiro.

\footnotetext{
${ }^{16}$ Ver, em especial, Chay et al. (Op cit, p. 1243).
} 


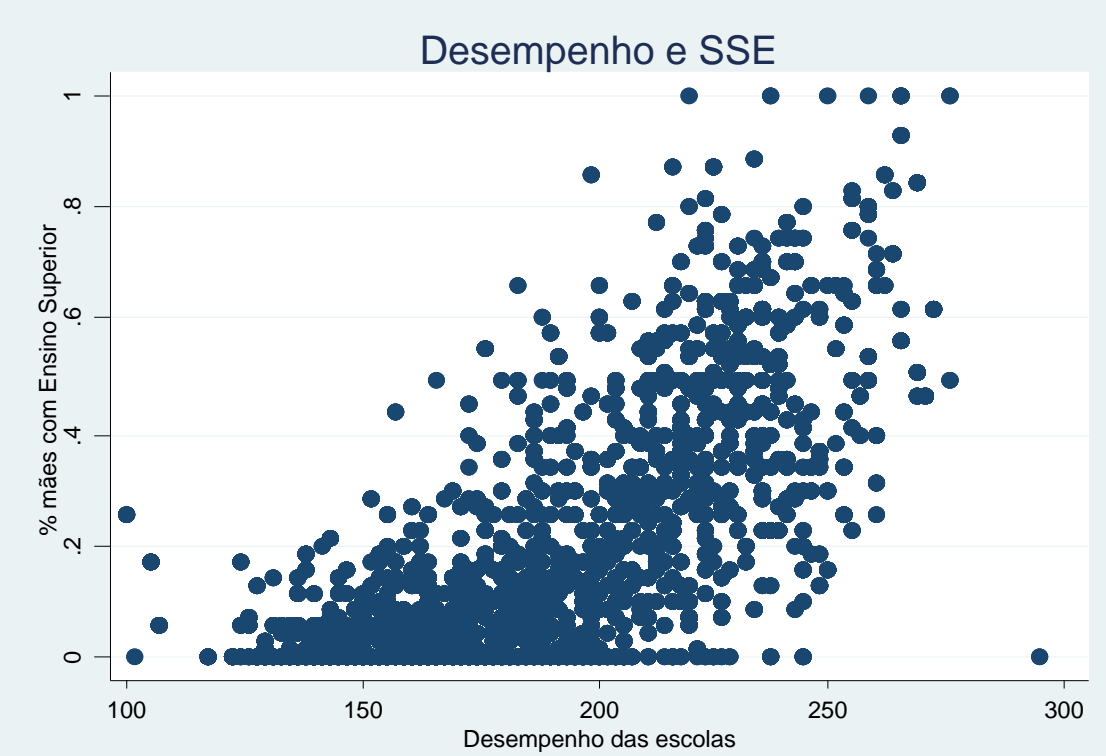

FIGURA 4 - Desempenho nas provas de matemática e português do SAEB e proporção de mães com ensino superior. média para escolas, alunos da $4^{\text {a }}$ série. Fonte: cálculos a partir das 480 escolas que se repetem nos anos de 1999, 2001 e 2003 do SAEB.

A Figura 5, por sua vez, mostra a relação entre o desempenho médio da escola e a proporção de mães com ensino médio. A relação também se mostra positiva, embora não tão acentuada e clara como no caso da Figura 4.

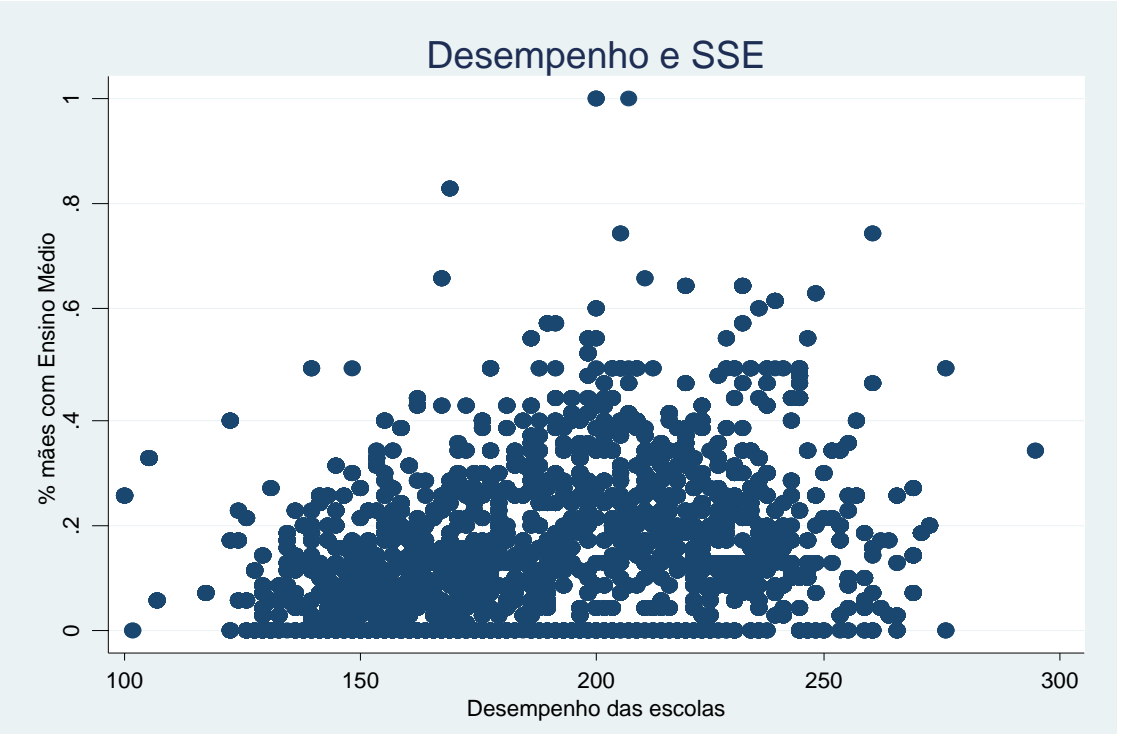

Figura 5 Desempenho nas provas de matemática e português do SAEB

e proporção de mães com ensino médio. Média para escolas, alunos da $4^{a}$ série.

Fonte: cálculos a partir das 480 escolas que se repetem nos anos de 1999, 2001 e 2003 do SAEB. 
Os Quadros 1, 2 e 3 abaixo mostram o ranking das 10 melhores escolas que se repetem no painel 1999-2003, sem controles para quaisquer características dos alunos, escolas , diretores, professores e turmas.

Quadro 1-Ranking das 10 melhores escolas de 1999

\begin{tabular}{|c|c|c|c|c|c|c|c|}
\hline $\begin{array}{c}10 \\
\text { melhores } \\
\text { de } 1999\end{array}$ & $\begin{array}{c}\text { Ranking } \\
2001\end{array}$ & $\begin{array}{c}\text { Ranking } \\
2003\end{array}$ & $\begin{array}{c}\text { Pontuação } \\
\text { média no SAEB } \\
1999 \\
\text { (matemática e } \\
\text { português) }\end{array}$ & $\begin{array}{l}\text { Desvio } \\
\text { padrão } \\
\text { (1999) }\end{array}$ & $\begin{array}{c}\text { Alunos } \\
\text { avaliados da } \\
4^{\mathrm{a}} \text { série } \\
(1999)\end{array}$ & $\begin{array}{l}\text { Média de } \\
\text { alunos por } \\
\text { sala de } \\
4^{\text {a }} \text { série } \\
(1999)\end{array}$ & $\begin{array}{l}\text { Matrículas } 4^{\mathrm{a}} \\
\text { série em } 1999\end{array}$ \\
\hline 1 & 84 & 6 & 293,55 & 26,40 & 6 & 8 & 8 \\
\hline 2 & 38 & 90 & 279,50 & 59,24 & 12 & 20 & 33 \\
\hline 3 & 105 & 9 & 275,85 & 20,59 & 4 & 8 & 14 \\
\hline 4 & 6 & 11 & 275,38 & 43,18 & 31 & 11 & 22 \\
\hline 5 & 3 & 3 & 265,08 & 34,01 & 68 & 34 & 344 \\
\hline 6 & 5 & 43 & 264,69 & 33,81 & 26 & 18 & 54 \\
\hline 7 & 27 & 47 & 260,49 & 41,87 & 63 & 33 & 185 \\
\hline 8 & 8 & 44 & 259,98 & 42,10 & 10 & 19 & 66 \\
\hline 9 & 1 & 1 & 259,65 & 32,47 & 58 & 34 & 143 \\
\hline 10 & 31 & 299 & 258,35 & 23,79 & 3 & 10 & 10 \\
\hline
\end{tabular}

Fonte: Cálculos a partir dos dados de 480 escolas que se repetem no SAEB 1999, 2001 e 2003.

No Quadro 1 pode-se perceber que há maior volatilidade nos resultados das escolas menores, com menos de 100 alunos matriculados na $4^{\mathrm{a}}$ série. O comportamento é tão mais volátil quanto menor o tamanho da escola e menor o número de alunos avaliados pelo SAEB. $\mathrm{O}$ mesmo padrão se observa nos quadros 2 e 3 que trazem os mesmos resultados das 10 primeiras escolas classificadas em 2001 e 2003, respectivamente.

Quadro 2-Ranking das 10 melhores escolas de 2001

\begin{tabular}{|c|c|c|c|c|c|c|c|}
\hline $\begin{array}{c}10 \\
\text { melhores } \\
\text { de } 2001\end{array}$ & $\begin{array}{c}\text { Ranking } \\
1999\end{array}$ & $\begin{array}{c}\text { Ranking } \\
2003\end{array}$ & $\begin{array}{c}\text { Pontuação } \\
\text { média no } \\
\text { SAEB 2001 } \\
\text { (matemática } \\
\text { e português) }\end{array}$ & $\begin{array}{c}\text { Desvio } \\
\text { padrão } \\
(2001)\end{array}$ & $\begin{array}{c}\text { Alunos } \\
\text { avaliados } \\
\text { da 4a série } \\
(2001)\end{array}$ & $\begin{array}{c}\text { Média de } \\
\text { alunos por } \\
\text { sala 4a série } \\
(2001)\end{array}$ & $\begin{array}{c}\text { Matrículas } \\
4^{\mathrm{a}} \text { série em } \\
2001\end{array}$ \\
\hline 1 & 9 & 1 & 270,04 & 32,47 & 58 & 32 & 178 \\
2 & 12 & 4 & 268,45 & 36,96 & 64 & 39 & 154 \\
3 & 5 & 3 & 263,72 & 34,01 & 68 & 32 & - \\
4 & 20 & 15 & 259,05 & 44,51 & 18 & 14 & 23 \\
5 & 6 & 43 & 258,86 & 33,81 & 26 & 14 & 40 \\
6 & 4 & 11 & 255,20 & 43,18 & 31 & 23 & 36 \\
7 & 51 & 478 & 254,98 & 50,82 & 18 & 9 & - \\
8 & 8 & 44 & 254,82 & 42,48 & 18 & 18 & 18 \\
9 & 31 & 62 & 254,46 & 35,30 & 35 & 19 & 96 \\
10 & 28 & 31 & 253,19 & 41,27 & 36 & 29 & 63 \\
\hline
\end{tabular}

Fonte: Cálculos a partir dos dados de 480 escolas que se repetem no SAEB 1999, 2001 e 2003. 
Quadro 3-Ranking das 10 melhores escolas de 2003

\begin{tabular}{|c|c|c|c|c|c|c|c|}
\hline $\begin{array}{c}10 \\
\text { melhores } \\
\text { de } 2003\end{array}$ & $\begin{array}{c}\text { Ranking } \\
1999\end{array}$ & $\begin{array}{c}\text { Ranking } \\
2001\end{array}$ & $\begin{array}{l}\text { Pontuação } \\
\text { média no } \\
\text { SAEB } 2003 \\
\text { (português e } \\
\text { matemática) }\end{array}$ & $\begin{array}{l}\text { Desvio } \\
\text { padrão } \\
(2003)\end{array}$ & $\begin{array}{c}\text { Alunos } \\
\text { avaliados } \\
\text { da } 4^{\mathrm{a}} \text { série } \\
(2003)\end{array}$ & $\begin{array}{l}\text { Média de } \\
\text { alunos por } \\
\text { sala de } \\
4^{\text {a }} \text { série } \\
(2003)\end{array}$ & $\begin{array}{c}\text { Matrículas } \\
4^{\mathrm{a}} \text { série } \\
(2003)\end{array}$ \\
\hline 1 & 9 & 1 & 272,48 & 32,47 & 58 & 31 & - \\
\hline 2 & 50 & 47 & 267,93 & 38,12 & 30 & 31 & 57 \\
\hline 3 & 5 & 3 & 267,85 & 34,01 & 68 & 32 & 235 \\
\hline 4 & 12 & 2 & 265,13 & 36,96 & 64 & 35 & 173 \\
\hline 5 & 15 & 18 & 265,07 & 30,16 & 13 & 14 & 10 \\
\hline 6 & 1 & 84 & 262,30 & 24,41 & 6 & 9 & - \\
\hline 7 & 25 & 12 & 261,99 & 41,54 & 20 & 20 & 28 \\
\hline 8 & 57 & 322 & 260,98 & 33,20 & 6 & 6 & 8 \\
\hline 9 & 3 & 105 & 259,34 & 20,59 & 4 & 4 & 4 \\
\hline 10 & 63 & 76 & 258,44 & 38,08 & 26 & 10 & 166 \\
\hline
\end{tabular}

Fonte: Cálculos a partir dos dados de 480 escolas que se repetem no SAEB 1999, 2001 e 2003.

\subsection{Metodologia}

Para aprofundar a análise do quanto medidas usuais utilizadas para construção de rankings de escola espelham principalmente o status socioeconômico ou, por outro lado, implicam em volatilidade demasiada de um ano para outro (ambos efeitos indesejados, caso estes rankings sirvam de parâmetros para a tomada de decisão dos agentes), serão calculadas cinco medidas de desempenho com base nos exames do SAEB de matemática para a $4^{\mathrm{a}}$ série, seguindo-se a abordagem dada por Mizala et al. (2007). Quatro dessas medidas são obtidas após o ajuste de um modelo de regressão, como descrito no Quadro 4.

Quadro 4- Descrição de 4 medidas de desempenho de escolas obtidas por meio de uma regressão

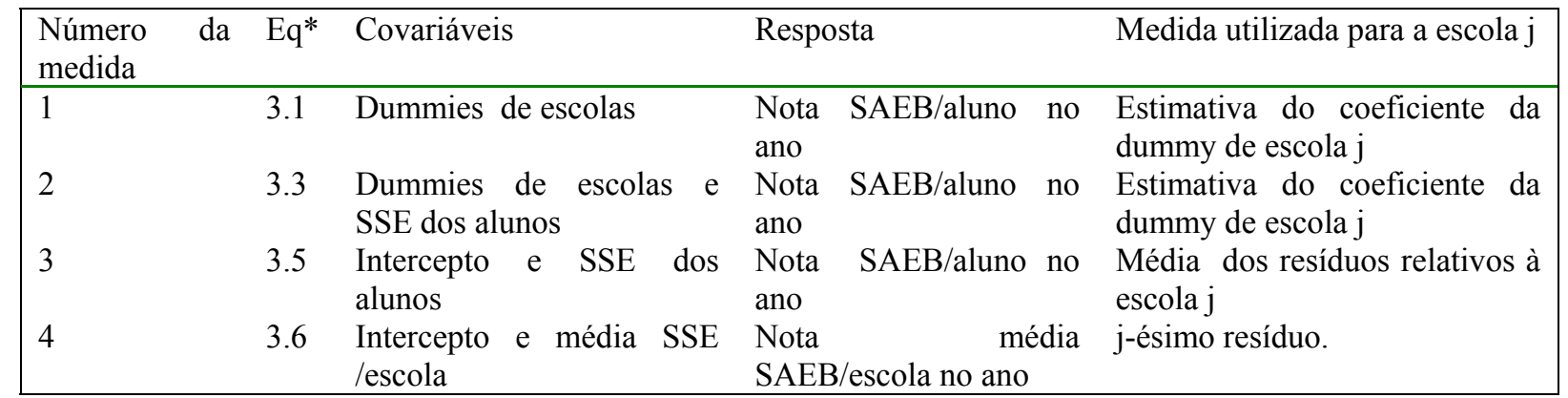

*Número da equação que descreve o modelo como aparece no texto.

A quinta medida é, para cada escola em um determinado ano, o acréscimo na média de notas SAEB /escola em relação ao ano anterior. 
A primeira destas medidas é a mais simples, pois utiliza dados cross section das notas de alunos e as escolas são ordenadas de acordo com suas médias. Esta medida aparece em praticamente todos os modelos de responsabilização. Num contexto de regressão, ela pode ser representada por uma constante específica da escola j, no modelo de regressão dado por:

$$
y_{i j}=\alpha_{j}+u_{i j} \quad i=1, \ldots . n_{j} ; j=1, \ldots 480
$$

Em (1) y $y_{\mathrm{ij}}$ é a nota do aluno i na escola $\mathrm{j}, \alpha_{\mathrm{j}}$ é o efeito da escola $\mathrm{j}$ e $\mathrm{u}_{\mathrm{ij}} \mathrm{o}$ erro idiossincrático. A equação (1) pode ser escrita também na forma vetorial como

$$
\mathbf{y}=\mathbf{D} \boldsymbol{\alpha}+\mathbf{u}
$$

sendo y: vetor $\mathrm{Nx} 1$ das observações da nota de cada aluno de cada escola $\mathrm{N}=\mathrm{n}_{1}+\mathrm{n}_{2}+\ldots .+\mathrm{n}_{480}$

D: matriz $\mathrm{Nx} 480$ contendo $1-\mathrm{s}$ e 0 -s

u: vetor de erros aleatórios $\mathrm{Nx} 1$

$\boldsymbol{\alpha}:$ vetor 480x1 de coeficientes de interceptos específicos de escolas.

Seja $\bar{y}_{j}=$ nota média dos alunos da escola j e $\overline{\mathbf{y}}$ o vetor 480x1 destas médias para todas as escolas. A estimativa a de $\boldsymbol{\alpha}$ é o vetor $\overline{\mathbf{y}}$ e espelha fortemente a composição do status socioeconômico dos alunos. Isto pode ser observado na Tabela 17 abaixo, em que foi realizada a regressão da nota média da escola em variáveis observáveis que capturam o status socioeconômico médio dos alunos que compõem a escola e suas famílias. Na ausência de informações sobre a renda das famílias, foram incluídas dummies para escolaridade da mãe e se o aluno tem ou não computador. Sendo $\overline{\mathbf{X}}$ a matriz $480 \times 8$ de médias por escola de 8 variáveis dummies que espelham o SSE dos alunos (sexo, educação da mãe com 6 níveis, e posse de computador pelo aluno), $\gamma$ um vetor $8 \times 1$ e $v$ um vetor $480 \times 8$ de erros idiossincráticos, foi ajustado o seguinte modelo:

$$
\overline{\mathbf{y}}=\overline{\mathbf{X}} \gamma+\mathbf{v}
$$


A Tabela 15 traz o $\mathrm{R}^{2}$ resultante da estimação por MQO do modelo (3.2) para cada ano.

Tabela 15-Valores de R2 em ajustes por MQO de regressões de $\overline{\mathbf{y}}$ sobre SSE (escola)

\begin{tabular}{cccc}
\hline & $1999\left(4^{\mathrm{a}}\right.$ Série $)$ & $2001\left(4^{\mathrm{a}}\right.$ série $)$ & 2003 ( $4^{\mathrm{a}}$ série $)$ \\
\hline $\mathrm{R}^{2}$ & $64,3 \%$ & $71,8 \%$ & $71,3 \%$ \\
\end{tabular}

Fonte : Cálculos a partir de 480 escolas que se repetem no SAEB 1999, 2001 e 2003.

*Variáveis regressoras: Valores médios por escola de Sexo, Educação da mãe (6 níveis), Computador em casa.

É possível observar que, mesmo na ausência da medida de renda da família, as variáveis disponíveis que espelham o status socioeconômico (SSE) dos alunos explicam entre 64\% e $71 \%$ dos resultados do desempenho médio observado da escola. Portanto, o ranking que emerge de $\boldsymbol{\alpha}$ no modelo (3.1), tem a desvantagem de refletir majoritariamente o SSE dos alunos que compõem a escola e, por isso, de não captar adequadamente o "efeito escola", o que seria desejável para guiar as decisões dos elaboradores de políticas educacionais e famílias.

Uma segunda medida de desempenho das escolas é a obtida a partir do ajuste de uma regressão das notas SAEB dos indivíduos que leva em conta o efeito específico de escola e a influência de variáveis SSE individuais. Essa regressão pode ser expressa por:

$$
\begin{array}{r}
y_{i j}=\delta_{j}+X_{i j} \beta+u_{i j} \\
i=1, \ldots, n_{j} ; j=1, \ldots 480
\end{array}
$$

Em (3.3) $y_{\mathrm{ij}}$ é a nota do aluno i na escola $\mathrm{j}, \delta_{\mathrm{j}}$ é o intercepto específico da escola j $\mathrm{X}_{\mathrm{ij}}$ é um vetor linha 1xp com as características de SSE do aluno i na escola j, $\boldsymbol{\beta}$ é um vetor px 1 e $\mathrm{u}_{\mathrm{ij}}$ é o erro idiossincrático.

Seja d o vetor 480x1 de estimativas dos interceptos específicos $\delta_{\mathrm{j}}$ de escolas no modelo (3.3). O vetor d é a segunda medida que pode ser usada para fazer o ranking de escolas..

Para avaliar se a segunda medida difere muito da primeira, pode-se verificar se há ganho no $\mathrm{R}^{2}$ da regressão quando se acrescenta as variáveis de controle SSE ao modelo de regressão. Usando a mesma simbologia usada no modelo (3.3), pode-se ajustar um modelo sem efeitos específicos de escolas dado por

$$
\begin{gathered}
y_{i j}=X_{i j} \boldsymbol{\beta}+u_{i j} \quad(3.4) \\
i=1, \ldots n_{j} ; j=1, \ldots 480
\end{gathered}
$$


A Tabela 16 mostra os valores de $\mathrm{R}^{2}$ obtidos nos ajustes dos modelos (3.1), (3.4) e (3.3), respectivamente.

Tabela 16-Valores de $\mathrm{R} 2$ em ajustes por MQO de 3 modelos de regressão linear da variável resposta "nota SAEB /aluno (português e matemática)"

\begin{tabular}{llll}
\hline & 1999 & 2001 & 2003 \\
\hline Modelo (3.1): apenas dummies de escolas & & & \\
$\mathrm{N}$ & 5.819 & 13.629 & 13.114 \\
$\mathrm{R}^{2}$ & $30,99 \%$ & $33,92 \%$ & $47,04 \%$ \\
& & & \\
Modelo (3.4): apenas controles de SSE dos alunos ${ }^{\mathrm{a}}$ & & & \\
$\mathrm{N}$ & 5.819 & 12.246 & 13.064 \\
$\mathrm{R}^{2}$ & $18,77 \%$ & $24,20 \%$ & $22,25 \%$ \\
& & & \\
Modelo (3.3): dummies de escolas e controles de SSE dos alunos & & & \\
$\mathrm{N}$ & 5.819 & 12.026 & 13.064 \\
$\mathrm{R}^{2}$ & $33,01 \%$ & 36,72 & $47,56 \%$ \\
\hline
\end{tabular}

Fonte: Cálculos a partir dos SAEB de 1999, 2001 e 2003.

No Modelo (3.4) os controles de SSE são 6 dummies para nível de educação da mãe, dummy de sexo do aluno e dummy para posse de computador pelo aluno.

Os resultados na Tabela 16 mostram que o modelo (3.1), que tem apenas dummies de escola como regressoras, explica entre $30,99 \%$ e $47,04 \%$ das variações nas notas. No modelo (3.4), observa-se que as características de SSE dos alunos explicam entre 18,77\% e 24,20\% da variação das notas. Comparando o modelo (3.3) com o modelo (3.1), observa-se que, uma controlada a regressão com dummies de escolas, as características de SSE adicionam pouca informação para a variação das notas (de 33,01\% a 47,56\%).

Isto indica que há uma forte correlação entre as estimativas (a e d) dos interceptos nas equações (3.1) e (3.3), precisamente de 81,95\% em 1999, 86,96\% em 2001 e 99,90\% em 2003, resultado que MIZALA et al. (Op cit) também encontraram para o caso do Chile. Segundo esses autores, isto sugere que o sistema apresenta uma forte estratificação social, e que a escolha de onde se matricular já transmite muito das características de SSE observáveis do aluno e, possivelmente, também das características não-observáveis que contribuem para o aprendizado.

A terceira medida é construída a partir dos resíduos que emergem da regressão da seguinte equação:

$$
\begin{gathered}
y_{i j}=\alpha_{0}+X_{i j} \boldsymbol{\beta}+v_{i j} \\
\mathrm{i}=1, \ldots \mathrm{n}_{\mathrm{j}} ; \mathrm{j}=1, \ldots 480
\end{gathered}
$$


Em (3.5) $y_{\mathrm{ij}}$ é a nota do aluno i na escola j, $\alpha_{0}$ é um intercepto comum a todas as escolas, $\mathrm{X}_{\mathrm{ij}}$ é um vetor linha 1xp com as características de SSE do aluno i na escola $\mathrm{j}, \boldsymbol{\beta}$ é um vetor px1 e $v_{\mathrm{ij}}$ é o erro idiossincrático.

Segundo Mizala et al. (Op cit), as escolas podem ser "rankeadas" de acordo com seu resíduo médio $\bar{v}_{j}$. Esta medida seria menos influenciada por características de SSE observáveis, uma vez que se faz o controle por elas em $\mathrm{X}_{\mathrm{ij}}$. Por outro lado, espera-se que ela seja mais volátil, pois não contém mais o efeito-escola específico que, como mostra a comparação das regressões (3.1) e (3.3), capta muito bem a influência da escola.

A quarta medida de desempenho da escola j é o j-ésimo resíduo do seguinte modelo de regressão:

$$
\begin{array}{r}
\bar{y}_{j}=\alpha_{0}+\overline{\mathbf{X}}_{j} \boldsymbol{\beta}+v_{j} \\
\mathrm{j}=1 \ldots 480
\end{array}
$$

Em (3.6) $\bar{y}_{j}$ é a nota média dos alunos da escola $\mathrm{j}, \alpha_{0}$ um intercepto comum, $\overline{\mathbf{X}}_{\mathrm{j}}$ a matriz $1 \mathrm{x} 8$ de médias da escola j de 8 variáveis dummies que espelham o SSE dos alunos (sexo, educação da mãe com 6 níveis, e posse de computador pelo aluno), $\boldsymbol{\beta}$ é um vetor $8 \times 1$ e $v_{\mathrm{j}}$ é o erro idiossincrático. Os resíduos $e_{j}$ resultantes do ajuste do modelo (3.6) são utilizados para montar o ranking.

Por fim, a quinta e última medida analisada aqui é a que se obtém pela diferença no desempenho médio das escolas de um ano $(\mathrm{t}=0)$ para o ano seguinte $(\mathrm{t}=1)$. Esta é uma medida bastante utilizada para se tentar capturar o "valor adicionado" da escola". Levando-se em conta as notas médias nos testes por escolas e as características de SSE médias de seu corpo discente, esta medida pode ser representada pela diferença entre as equações (3.7a) e (3.7b), dada em (3.7c)

$$
\begin{gathered}
\bar{y}_{j 0}=\alpha_{j}+\overline{\mathbf{X}}_{j 0} \boldsymbol{\beta}+\bar{v}_{j 0} \\
\bar{y}_{j 1}=\alpha_{j}+\overline{\mathbf{X}}_{j 1} \boldsymbol{\beta}+\bar{v}_{j 1} \\
\Delta \bar{y}_{j}=\bar{y}_{j 1}-\bar{y}_{j 0}=\bar{v}_{j 1}-\bar{v}_{j 0} \\
\mathrm{j}=1 \ldots 480
\end{gathered}
$$

\footnotetext{
${ }^{17}$ Para ser mais precisa, a mensuração correta do valor adicionado pela escola exige que se acompanhe o progresso de cada aluno ao longo dos anos. No Brasil, e também na maioria dos países em desenvolvimento, este tipo de informação ainda não está disponível.
} 
Nas equações (3.7a) a (3.7c), $\bar{y}_{j t}$ é a nota média dos alunos da escola j no tempo t, $\alpha \mathrm{j}$ é o efeito-escola específico da escola $\mathrm{j}$ e $\mathrm{t}=0,1$. Se a composição socioeconômica média da escola é estável no tempo, e é bastante razoável se esperar que o seja, a diferença entre (3.7a) e (3.7b) elimina a sua influência bem como o efeito específico da escola que não varia no tempo. Por isso, a volatilidade que pode emergir do ranking com a medida dada por $(3.7 \mathrm{c})$ dependerá da diferença $\Delta \bar{y}_{j}=\bar{v}_{j 1}-\bar{v}_{j 0}$, muito influenciável por choques ocorridos em apenas um dado momento que podem ou não perdurar no tempo.

\subsection{Resultados}

Nos Quadros 5 e 6 estão os resultados esperados para o caso do ranking de escolas ter caráter completamente estável, caso de volatilidade esperada nula (coluna 1), ou ter o comportamento de uma loteria, caso de volatilidade esperada máxima (coluna 2) ${ }^{18}$. Estas duas situações extremas servem de parâmetro para se comparar a volatilidade dos rankings obtidos pelas cinco diferentes medidas acima apresentadas.

Quadro 5-Distribuições teóricas de freqüências percentuais do "número de vezes (k) em que uma escola aparece entre as $\mathbf{2 0} \%$ melhores em 3 anos" nos casos de "certeza" e "loteria" comparadas com freqüências percentuais "número de escolas que aparecem $k$ vezes/ número total de escolas (480)" segundo várias medidas

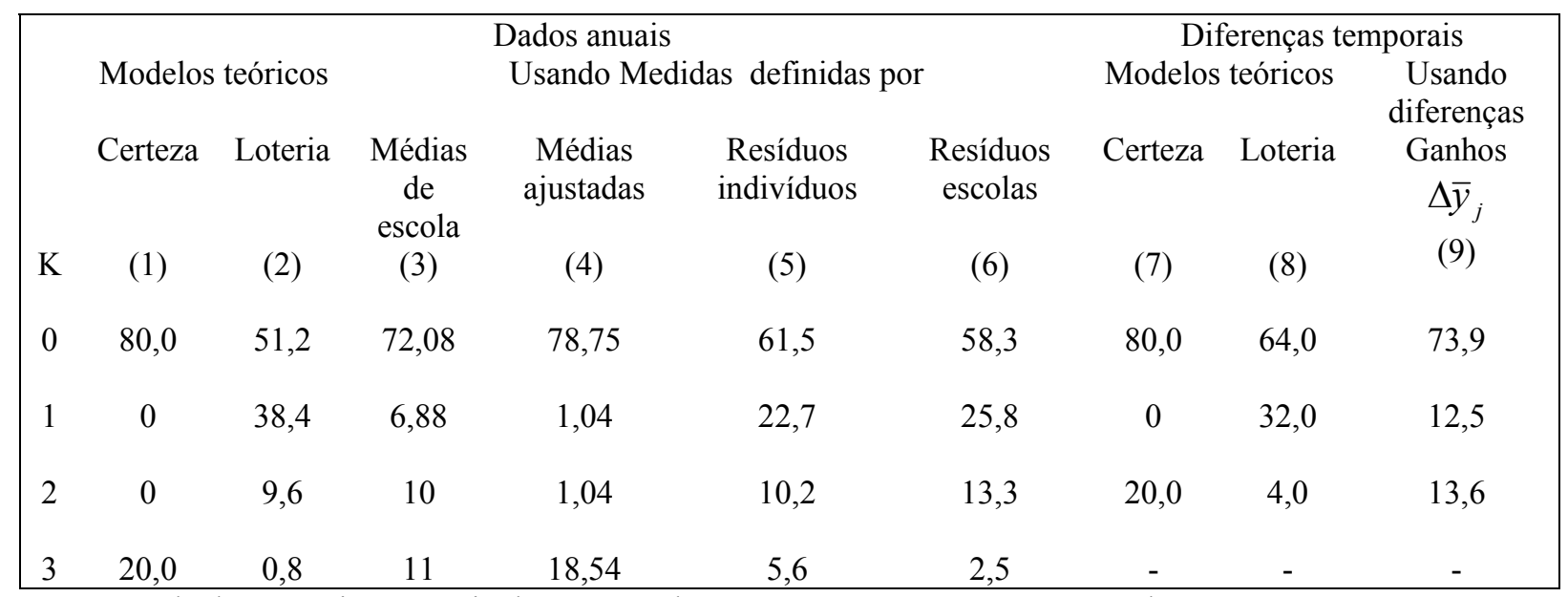

Fonte: Cálculos próprios a partir de 480 escolas que se repetem nas amostras do SAEB 1999,2001 e 2003. Rankings com base em medidas obtidas a partir dos dados de alunos da $4^{\mathrm{a}}$ série em matemática e português.

\footnotetext{
${ }^{18}$ A loteria é simulada encarando-se cada julgamento de escola como um ensaio de Bernoulli independente dos demais ensaios, com M sendo o número de ensaios e 0,20 a probabilidade de sucesso. Assim, a probabilidade de $\mathrm{K}$ sucessos é dada pela Binomial $(\mathrm{M}=3, \mathrm{P}=0,2): \mathrm{P}($ Número de sucessos $=\mathrm{k})=\mathrm{M} ! /[\mathrm{k} !(\mathrm{M}-\mathrm{k}) !] 0,20^{\mathrm{k}}(0,80)^{\mathrm{M}-\mathrm{k}}$, $\mathrm{k}=0,1,2 \ldots \mathrm{M}$.
} 
Quadro 6-Distribuições teóricas de freqüências percentuais do "número de vezes (k) em que uma escola aparece entre as $20 \%$ piores em 3 anos" nos casos de "certeza" e "loteria" comparadas com freqüências percentuais "número de escolas que aparecem $k$ vezes/ número total de escolas (480)" segundo várias medidas

\begin{tabular}{|c|c|c|c|c|c|c|c|c|c|}
\hline & & & & Dados an & & & Difer & nças tem & orais \\
\hline & Modelos & teóricos & & Usando & las definidas & & Modelos & teóricos & Usando \\
\hline & Certeza & Loteria & Médias & $\begin{array}{l}\text { Médias } \\
\text { ajustadas }\end{array}$ & $\begin{array}{l}\text { Resíduos } \\
\text { indivíduos }\end{array}$ & $\begin{array}{l}\text { Resíduos } \\
\text { escolas }\end{array}$ & Certeza & Loteria & $\begin{array}{c}\text { Ganhos } \\
\Delta \bar{y}_{j}\end{array}$ \\
\hline K & (1) & (2) & (3) & (4) & (5) & (6) & (7) & (8) & (9) \\
\hline 0 & 80,0 & 51,2 & 65,83 & 77,92 & 62,9 & 56,46 & 80,0 & 64,0 & 71,1 \\
\hline 1 & 0 & 38,4 & 15,63 & 2,50 & 19.2 & 29,17 & 0 & 32,0 & 18,1 \\
\hline 2 & 0 & 9,6 & 11,25 & 1,25 & 12,9 & 12,29 & 20 & 4,0 & 10,8 \\
\hline 3 & 20,0 & 0,8 & 7,29 & 18,33 & 5,00 & 2,1 & - & - & - \\
\hline
\end{tabular}

Fonte:Cálculos próprios a partir de 480 escolas que se repetem nas amostras do SAEB 1999,2001 e 2003. Rankings com base em medidas obtidas a partir dos dados de alunos da $4^{\mathrm{a}}$ série em matemática e português.

O comportamento do ranking que emerge das médias "puras" das notas por escolas na equação (3.1) pode ser visto nos Quadros 5 e 6. Como exemplo, no Quadro 5, coluna 3, verifica-se que $72,08 \%$ das escolas nunca apareceram entre as $20 \%$ melhores, nos três anos analisados. Esta proporção é muito próxima do caso de "certeza", que seria de $80 \%$ o que indica estabilidade na posição dessas escolas Por outro lado, 11\% das escolas aparecem nos três anos, segundo esta medida, entre as $20 \%$ melhores. Esses dados mostram que esta medida gera rankings com caráter certo, o que é bastante desejável. Mas, como visto na discussão da Tabela 15, o ranking definido pelas médias puras reflete o status socioeconômico dos alunos. Como Mizala et al. ( Op cit) encontraram para o caso do Chile, aqui o ranking é estável mas reflete fundamentalmente o SSE.

Quanto à volatilidade do ranking com base em $\mathbf{d}$ que surge da equação (3.3), a coluna 4 do Quadro 5 mostra que a distribuição que emerge deste tipo de medida é ainda mais estável do que o resultado apresentado pelas médias puras. Este resultado é esperado, uma vez que o que se está medindo é o efeito específico não-observado da escola que, no contexto de uma regressão, não varia no tempo. Porém, mais uma vez, embora a estabilidade seja desejável, esta medida tem fundamentalmente como base o SSE dos alunos das escolas, como mostram as elevadas correlações entre d da equação (3.3) e a da equação (3.1) (ver seção 4). 
A coluna 5 do Quadro 5 mostra que a distribuição da medida resultante do modelo de regressão da equação (3.5) apresenta maior volatilidade que as demais vistas até aqui, e aproxima-se da distribuição de uma loteria.

A coluna 6 do Quadro 5 mostra a elevada volatilidade na distribuição que a medida resultante do modelo de regressão dado pela equação (3.6) gera, apesar desta medida controlar bem pelo SSE e os efeitos específicos não-observados das escolas.

Já o que se pode observar na coluna 9 do Quadro 5, com respeito à quinta medida obtida a partir da equação (3.7c), é que a distribuição resultante da utilização das diferenças nas médias de notas de um ano para o outro, apresenta um caráter bastante estável, o que é desejável, e ao mesmo tempo expurga de seus resultados os efeitos do SSE dos alunos.

Pode-se afirmar, portanto, que de todas as medidas aqui avaliadas, a medida dada por (3.7c) seria uma boa medida para servir de referência nas avaliações sobre a qualidade nas escolas, uma vez que controla os efeitos do SSE dos alunos e os efeitos específicos não-observados das escolas e apresenta, ao mesmo tempo, estabilidade. Este resultado difere daquele encontrado em Mizala et al. (Ibid). Uma explicação, talvez, seja que aquele estudo contou com um período mais longo de observações ( 8 anos) e também com dados de natureza censitária de uma região específica do Chile. De acordo com os seus resultados, a distribuição do ranking com base nas diferenças se aproximava claramente ao de uma distribuição de loteria. No caso do Brasil, porém, dado que o SAEB é uma amostra representativa da população, o uso da diferença nas médias apresentou as características desejáveis para uma medida de qualidade das escolas: não é influenciada pelo SSE e variáveis escolas-específicas não-observadas, e também não apresenta no tempo uma volatilidade próxima à de um resultado de loteria. O ideal, porém, seria poder contar com dados mais completos, como aqueles que agora estão sendo gerados na Prova Brasil, colhidos por um período mais longo de tempo.

\subsection{Comentários finais}

Os resultados acima alertam para o cuidado que os agentes econômicos devem ter ao tomarem como base os rankings de escolas, construídos a partir de exames de avaliação educacional 
como o SAEB, para fazerem inferências sobre a qualidade nas escolas ou para o desenho de incentivos e sanções num contexto de "políticas de responsabilização".

A elevada estratificação do sistema, por um lado, e o processo de reversão para a média que tende a ocorrer nos resultados de um momento no tempo para o outro, geram ruídos nas medidas de desempenho utilizadas para a construção de rankings, de forma a que estes podem apresentar resultados influenciados principalmente pelo status socioeconômico dos alunos ou uma volatilidade grande de um período de avaliação para o outro.

Das cinco medidas estudadas neste trabalho, apenas aquela que leva em conta a diferença nas médias (equação 3.7c) resultou num ranking com as desejáveis características de não ser fortemente determinado pelo SSE dos alunos e pelas variáveis não-observáveis das escolas e, ao mesmo tempo, apresentar baixa volatilidade. Para que se afirme com maior certeza este resultado, porém, é necessário aguardar os levantamentos da Prova Brasil, que tem caráter censitário, por um número maior de anos. No Brasil, como é crescente a preocupação com a qualidade do ensino público, e se caminha para políticas nos moldes de "responsabilização", os resultados aqui encontrados são bastante importantes para serem levados em conta na definição de índices de desempenho e de metas a serem atingidas pelas escolas. 

PERSPECTIVA

\subsection{Introdução}

Discute-se sobre como elevar a qualidade do sistema educacional público brasileiro, se é preciso elevar os recursos destinados à educação, em particular no que diz respeito à remuneração dos professores, para que bons profissionais sejam atraídos e mantidos na rede pública. Esta questão é discutida também no âmbito internacional: quanto recursos extras para as escolas e os professores podem efetivamente contribuir para a melhoria da qualidade de ensino e diminuir as desigualdades?

O FUNDEF (Fundo para Manutenção e Desenvolvimento do ensino fundamental e Valorização do Magistério) foi um programa do governo federal que entrou em vigor em janeiro de 1998, a princípio para durar dez anos, e que significou uma profunda transformação na forma de financiamento do ensino fundamental público do país ${ }^{19}$. Além de garantir maiores recursos pra este nível de ensino em particular, o FUNDEF estabeleceu regras antes inexistentes para a distribuição destes recursos entre estados e municípios, que passou a depender do número de alunos matriculados nas respectivas redes sob responsabilidade de cada esfera pública dentro dos estados. Além disso, vinculou $60 \%$ dos mesmos a gastos com salários dos professores do ensino fundamental exclusivamente.

Por ter significado uma mudança exógena nos recursos destinados à educação no sistema público, o FUNDEF proporciona uma importante experiência para se testar o efeito que variações nos recursos disponíveis para gastos com educação e com salários dos professores exercem sobre o sistema público de ensino.

Procurar explorar todos os efeitos que um programa de tal envergadura possa ter produzido no ensino público brasileiro não é tarefa simples. Primeiramente porque, concomitante a ele, outras importantes mudanças ocorreram no sistema educacional brasileiro e seus efeitos

\footnotetext{
${ }^{19}$ O FUNDEF foi substituído pelo FUNDEB em 2007. O novo Fundo estendeu a lógica de financiamento do Ensino Fundamental instaurada pelo FUNDEF pra todo o Ensino Básico.
} 
podem não ser claramente identificados e separados dos efeitos provocados pelo FUNDEF. Como exemplos, tem-se a adoção do programa de progressão continuada em algumas redes escolares, sem que esta tenha sido generalizada ou obedecido a um calendário de implementação único, e o processo de descentralização (ou municipalização) do ensino fundamental em todo o país, que também não obedeceu regras claras em cada estado e não ocorreu de forma homogênea no tempo (ver Madeira, 2007).

Apesar destes desafios, este trabalho busca analisar os efeitos do FUNDEF sobre os seguintes indicadores educacionais na rede pública que oferece o ensino fundamental: o número de alunos matriculados; o número de professores neste nível de ensino; a razão aluno por professor; o efeito do Fundo sobre alguns indicadores de infra-estrutura nas escolas, como a existência de bibliotecas, laboratórios de informática, de ciências e quadras de esporte; o efeito sobre a qualidade dos professores, em termos de seu nível educacional; taxa de reprovação, taxa de aprovação e taxa de abandono, para o ensino fundamental como um todo e por série.

Utilizando-se a metodologia de diferenças em diferenças, e tomando-se como grupo de tratamento as escolas municipais, compara-se a evolução destes indicadores para todos os municípios nos anos de 1997, 1999, 2001, 2003 e 2005, tomando-se as escolas privadas como grupo de controle.

Para as informações sobre as características dos professores, escolas e desempenho e evasão escolar, são utilizadas as informações do Censo Escolar, um levantamento do Ministério da Educação $^{20}$. Para as informações sobre os recursos recebidos e transferidos para o FUNDEF por município e unidade da federação, são utilizados os dados do Ministério da Fazenda sobre Finanças Públicas Municipais (FINBRA).

Este trabalho está dividido da seguinte forma, além desta introdução: a seção 4.2 traz o referencial teórico, a seção 4.3 descreve as características do FUNDEF, a seção 4.4 apresenta a estratégia empírica, a seção 4.5 apresenta as fontes de dados e algumas estatísticas descritivas, a seção 4.6 traz os resultados das análises e a seção 4.7 os comentários finais.

\footnotetext{
${ }^{20}$ Apenas no caso da avaliação sobre o nível educacional dos professores é que foi preciso utilizar como referência as características do Censo Escolar 1996, pois no Censo Escolar 1997 tais informações não estão disponíveis.
} 


\subsection{Referencial teórico}

Um dos principais objetivos do FUNDEF foi valorizar o ensino fundamental, em especial seus professores, através da vinculação obrigatória de $60 \%$ dos recursos do Fundo ao salário destes profissionais. $\mathrm{Na}$ literatura internacional buscou-se o que se espera que ocorra, em termos de melhoria na qualidade dos profissionais, quando o governo lança mão de uma política de valorização dos salários. Na literatura Nacional, por sua vez, buscou-se os trabalhos que avaliaram, até o momento, o impacto do FUNDEF sobre o salário dos professores e sobre outros aspectos do sistema educacional brasileiro.

\subsubsection{Literatura internacional}

Em países em desenvolvimento é de se esperar que políticas voltadas para elevação de recursos surtam mais efeitos sobre o desempenho dos alunos do que em países desenvolvidos, pois os países em desenvolvimento partem de um ponto inferior no nível de recursos existentes. Porém, a forma de realizar esses gastos em busca de melhorias efetivas na qualidade do ensino continua merecendo atenção por parte dos elaboradores de políticas educacionais. Não basta elevar os gastos sem uma correta percepção de como esses recursos efetivamente contribuiriam para a melhoria da qualidade. Hanushek (2005c) argumenta que poucos países obtiveram sucesso na busca de melhorar a qualidade de suas escolas ${ }^{21}$. A razão, segundo o autor, é que pouco se atentou para a importância da qualidade dos professores, e que, por isso, as políticas que visam aumentar a capacitação e experiência dos mesmos não surtiram efeito sobre o desempenho dos alunos.

O debate acerca de como elevar a oferta de bons professores ainda está em aberto. Apesar de toda ênfase que Hanushek costuma dar ao papel do professor na qualidade do ensino, ele é cético quanto à capacidade do aumento de recursos per se de melhorar a qualidade. Em Hanushek (2002) defende-se desenhar um sistema de incentivos com foco no desempenho dos alunos, e não se desperdiçarem recursos com "políticas de insumo", que a seu ver são "pouco ficazes". Argumenta que a chave está na criação de incentivos de desempenho para professores e as pessoas das escolas: as escolas devem ser organizadas de tal forma a

\footnotetext{
${ }^{21}$ Como melhorar a qualidade nas escolas é ainda um desafio para os elaboradores de políticas educacionais e há uma forte corrente que defende que a saída não está correlacionada com os níveis de gasto no setor. Para uma maior discussão das evidências internacionais, ver HANUSHEK (2002, 2005a, 2005c), HANUSHEK e RIVKIN (2004) e BARBER e MOURSHED (2007). Para o caso do Brasil ver, por exemplo, MENEZES-FILHO (2007).
} 
relacionar a carreira e o trabalho desses profissionais com o desempenho dos estudantes, e para isso é preciso mudar a estrutura de incentivos. Em Hanushek et al. (1999) defende-se a idéia de que o poder de salários mais elevados atraírem professores mais qualificados é limitado.

Já no estudo de Barber e Mourshed (2007), realizado para verificar o que os países com os melhores sistemas educacionais do mundo em termos de qualidade fizeram e estão fazendo para alcançar a excelência no ensino público, os autores chegaram a três conclusões, dentre elas a de que a qualidade de um sistema educacional não pode exceder a qualidade de seus professores. No centro do aprendizado e da qualidade do ensino, os autores colocam a valorização dos professores e dos diretores das escolas: em todos os países analisados, independentemente do grau de centralização do sistema, de sua história ou cultura nacional, estes profissionais são atraídos por diversas políticas de incentivo, principalmente monetário, de forma que conseguem recrutar para a formação de professores o terço superior da distribuição de cada geração de formandos, no que no Brasil corresponderia ao $2^{\circ} \operatorname{grau}^{22}$. Dentre as principais formas de atrair bons profissionais destaca-se a equiparação do salário de um professor iniciante ao salário inicial dos demais recém formados que entram no mercado, a valorização do "status" da profissão de professor ${ }^{23}$, além de um processo de seleção para a entrada na profissão muito acirrado e controlado pelo estado (Ibid., p. 19).

Outro estudo que destaca a importância do diferencial de salários para a atração e manutenção de bons profissionais é o de Clotfelter et al.. (2007). O estudo traz evidências de que um programa de intervenção do governo no Estado da Carolina do Norte, que oferecia um bônus salarial de \$1.800 para professores certificados em determinadas disciplinas que trabalhassem em escolas com elevada taxa de pobreza ou baixo desempenho acadêmico, foi capaz de reduzir em $17 \%$ a taxa de rotatividade dos professores-alvo nestas escolas mais carentes, apesar de sua curta duração (2001, 2002 e 2003). Além disso, o estudo mostra que os professores que mais responderam ao incentivo foram os mais experientes, e a experiência do

\footnotetext{
${ }^{22} \mathrm{Na}$ Coréia do Sul são recrutados os 5\% melhores, na Finlândia os 10\% e os 30\% melhores em Singapura e Hong Kong . Nos Estados Unidos, os programas de sistemas em rápida melhoria, como o "Boston Teaching Residency", o "Ney York Teaching Fellows" e o "Chicago Teaching Fellows" fazem a mesma coisa, recrutando os graduados das melhores universidades.

${ }^{23}$ Segundo (BARBER e MOURSHED, 2007), a Inglaterra conseguiu transformar o professor na profissão mais popular entre os alunos do $2^{\circ}$ e $3^{\circ}$ grau em apenas cinco anos. Mesmo nos países em que a profissão já tem um status elevado, como a Finlândia e a Coréia do Sul, o Governo elevou o status do professor primário em relação ao secundário controlando a oferta de professores em cada nível ou oferecendo um pequeno diferencial mensal no salário para os professores do ensino primário.
} 
professor é uma das poucas características observáveis que, na literatura internacional, se encontraria relacionada ao aprendizado dos alunos (CLOTFELTER et al., 2007, p. 18).

Por fim, Guryan (2003) avalia o impacto de uma política de equalização de gastos com educação pública dentro do Estado de Massachusetts. O estudo aponta que os distritos que receberam recursos adicionais do estado elevaram os gastos em atividades relacionadas à sala de aula, e especificamente com professores. Seus resultados mostram ainda que, por conta da elevação da taxa de gastos por aluno, houve ganho de desempenho dos alunos da $4^{\mathrm{a}}$ e $8^{\mathrm{a}}$ série nas avaliações de ciências, matemática, leitura e estudos sociais.

\subsubsection{Literatura nacional}

No que diz respeito à literatura nacional sobre o tema, Anuatti et al. (2003) apontam que houve ganho salarial relativo a favor dos professores das escolas públicas decorrentes do FUNDEF. Segundo este estudo, os principais beneficiados pelo programa (em termos de ganhos salariais) foram os professores de escolas municipais, localizadas em cidades pequenas e, em termos regionais, pertencentes às regiões menos favorecidas (Nordeste, Norte e Centro-Oeste $)^{24}$.

Já Menezes-Filho e Pazello (2007) analisam o impacto do FUNDEF sobre a proficiência dos alunos e os salários dos professores, no ano imediatamente posterior à criação do programa. Os autores utilizam como grupo de tratamento as escolas públicas (municipais e estaduais), e como grupo de controle as escolas particulares, e encontram um efeito positivo significativo do mesmo sobre os salários e sobre a proficiência.

Por outro lado, Andrade et al. (2008) argumentam que o FUNDEF gerou incentivos para que professores aumentassem a taxa de repetência dos alunos e com isso também os seus salários, uma vez que os recursos do FUNDEF, da forma como desenhado, seriam diretamente proporcionais ao número relativo de alunos matriculados nas escolas públicas de estados e municípios. $\mathrm{O}$ aumento da taxa de repetência seria observado nas últimas séries do ensino fundamental (de $5^{\mathrm{a}}$ a $8^{\mathrm{a}}$ série), por serem as que apresentam menores taxas de evasão e, além

\footnotetext{
${ }^{24}$ Outros estudos para o caso do Brasil apontam que, em geral, o salário dos professores das redes públicas de ensino vem aumentando nos últimos dez anos e que, além disso, o diferencial de salários em relação ao pago pelo setor privado e outras ocupações no setor público, em geral, também tem diminuído (ver Afonso, 2007; Barbosa Filho e Pessôa, 2008).
} 
disso, apenas nos municípios com pequeno número de escolas, em que a ação individual de uma escola (agente) teria poder de influenciar o resultado final do jogo (receber mais recursos por ter mais alunos matriculados).

Os trabalhos sobre o FUNDEF realizados até aqui, pelo menos dos quais se tem conhecimento, analisaram efeitos parciais do programa sobre determinados indicadores educacionais. Por exemplo, com relação às conclusões que Andrade et al. (2008) chegaram, pode ser que o aumento da taxa de repetência nas últimas séries do ensino fundamental (de $5^{\text {a }}$ a $8^{\mathrm{a}}$ série), tenha sido decorrente de um aumento relativo nas matrículas nas escolas públicas nestas séries, o que pode ter levado a uma queda da qualidade, ou seja devido à melhora do quadro profissional por conta de uma melhoria nos salários proporcionada pelo FUNDEF.

Neste trabalho investiga-se o quanto o FUNDEF contribuiu para a melhoria da qualidade dos professores do ensino fundamental e sua influência sobre os indicadores de matrículas, fluxo, rendimento escolar e indicadores de infra-estrutura. Vale ressaltar ainda que esta análise não se limita ao ano imediatamente posterior à entrada em vigor do Fundo (1999), como nos trabalhos acima mencionados, mas procura captar os efeitos ao longo do tempo, incluindo os anos de 2001, 2003 e 2005 na análise. A perspectiva de um período de tempo maior traz mais substrato para investigar os resultados decorrentes do FUNDEF.

\subsection{O FUNDEF}

O FUNDEF (Fundo de Manutenção e Desenvolvimento do ensino fundamental e de Valorização do Magistério) foi criado em 1997 e entrou em vigor a partir de $1^{\circ}$ de janeiro de 1998 em todo o país, exceto no Estado do Pará, onde teve início em julho de 1997. O FUNDEF alterou a estrutura de financiamento do ensino fundamental público do país, pela subvinculação de uma parcela dos recursos da educação a esse nível de ensino, com distribuição de recursos automática de acordo com o número de alunos matriculados nas redes municipal e estadual de ensino fundamental. 
No Brasil o atual sistema educacional compreende o ensino básico - que consiste na educação infantil (creches e pré-escolas), no ensino fundamental, com duração mínima de oito anos ${ }^{25}$, e no ensino secundário (ensino médio), com duração de três anos - e o ensino superior, com duração média entre quatro e cinco anos. Os alunos são atendidos por redes de ensino federal, estadual e municipal, além da rede privada. No que diz respeito ao ensino básico, é de responsabilidade dos municípios agir prioritariamente na educação infantil e no ensino fundamental, enquanto estados e Distrito Federal atuam igualmente no ensino fundamental e no ensino secundário (ou médio).

O ensino fundamental, com duração mínima de oito anos, é obrigatório e gratuito nas escolas públicas (estaduais e municipais), e cabe ao governo garantir que todos tenham acesso ao mesmo, inclusive quem não o teve na idade adequada. Este foi o nível de ensino alvo do FUNDEF.

A constituição de 1988 estabeleceu que 25\% das receitas totais de estados e municípios e 18\% das receitas da União fossem gastos com educação, mas não estabeleceu regras para o emprego destes recursos e nem mecanismos de fiscalização. Embora atendesse a uma reivindicação antiga da sociedade por reserva e garantia de mais recursos para a educação, a lei não solucionou o problema da disparidade de recursos existentes entre as redes de ensino em cada estado e entre unidades da federação, e não conseguiu garantir o financiamento adequado do ensino obrigatório (SEMEGHINI, 2001). A heterogeneidade observada nas escolas se agravou porque estados e municípios com diferentes demandas por educação apresentavam recursos e gastos por alunos que variavam diretamente à renda per capita da região e inversamente à demanda por educação pública na mesma. Estados ou municípios ricos, com poucas escolas, acabavam apresentando elevado gasto por aluno, e não havia garantia alguma de que estes correspondessem realmente a gastos no sistema educacional em $\mathrm{si}^{26}$.

A partir da entrada em vigor do FUNDEF, $60 \%$ das receitas totais que cabia aos gastos com educação de estados em municípios passaram a ser obrigatoriamente gastos na manutenção e

\footnotetext{
${ }^{25}$ Em 2005 o Governo Federal decretou uma lei que obriga as escolas públicas a aumentarem, em um prazo de cinco anos (até 2010), a duração do Ensino Fundamental de 8 para 9 anos.

${ }^{26}$ Como ressalta MENEZES-FILHO e PAZELLO (2007), em Municípios ricos em que sobravam recursos, os gastos eram feitos em atividades pouco relacionadas à educação, como pavimentação de ruas próximas à escola, construção de ginásios de esportes etc.
} 
desenvolvimento da Educação Fundamental. Porém, ao invés de serem diretamente aplicados nas diferentes esferas de governo, estes recursos passaram a ir antes para um fundo comum do estado e então, num segundo momento, redistribuídos para estados e municípios na mesma proporção de alunos matriculados nas suas escolas de ensino fundamental. O Fundo foi composto, basicamente, por recursos próprios de estados e municípios, originários de fontes já existentes, sendo constituído de $15 \%$ do:

- Fundo de Participação dos Estados - FPE;

- Fundo de Participação dos Municípios - FPM;

- Imposto sobre a Circulação de Mercadorias e Serviços - ICMS (incluindo os recursos relativos à desoneração de exportações, de que trata a Lei Complementar $n^{0} 87 / 96$ );

- Imposto sobre Produtos Industrializados, proporcional às exportações - IPIexp.

Além desses recursos, houve complementação por parte do governo federal para que fosse garantido um valor anual mínimo por aluno aos governos estaduais e municipais no âmbito do estado em que este valor per capita não fosse alcançado ( INEP, 2004).

Os recursos do Fundo iam para os estados e municípios que atendem alunos do ensino fundamental em suas respectivas redes de ensino público de acordo com o número de matrículas reportado pelo Censo Escolar do ano anterior. As matrículas na Educação Infantil (creche e pré-escola) e no ensino médio e ensino supletivo, em qualquer nível, não eram consideradas para efeito da distribuição de recursos do Fundo.

Em 1998 e 1999, os coeficientes de distribuição dos recursos foram estabelecidos com base no número de alunos do ensino fundamental regular. Porém, a partir de 2000, houve mudança na regra de alocação, de maneira que o cálculo passou a ser realizado considerando-se:

- O número de matrículas no ensino fundamental regular ( $1^{\mathrm{a}}$ à $4^{\mathrm{a}}$ série e $5^{\mathrm{a}}$ à $8^{\mathrm{a}}$ série$)$ e na Educação Especial;

- O valor mínimo nacional por aluno, diferenciado para os segmentos de $1^{\mathrm{a}}$ à $4^{\mathrm{a}}$ série, da $5^{\mathrm{a}}$ à $8^{\mathrm{a}}$ série e da Educação Especial (em todos os níveis);

- Diferencial de 5\% no valor por aluno / ano dos alunos de $5^{\mathrm{a}}$ à $8^{\mathrm{a}}$ e Educação Especial com relação aos alunos da $1^{\mathrm{a}}$ à $4^{\mathrm{a}}$ série.

Seguindo essas regras, calculava-se o coeficiente de distribuição dos recursos do Fundo de um dado município ou governo estadual de acordo com a fórmula: 


$$
C D=\frac{\{[F D 1(N A 1 a 4+E N M 1 a 4)]+[F D 2(N A 5 a 8+E N M 5 a 8+N A e+E N M e]\}}{\{[F D 1(T A 1 a 4+T E N M 1 a 4)]+[F D 2(T A 5 a 8+T A e+T E N M 5 a 8+T E N M e)]\}}
$$

Onde:

$\mathbf{C D}=$ coeficiente de distribuição dos recursos

FD1 $=$ fator de ponderação das matrículas de $1^{\mathrm{a}}$ à $4^{\mathrm{a}}$ série do ensino fundamental regular $=$ 1,00

FD2 = fator de ponderação das matrículas de $5^{\mathrm{a}}$ à $8^{\mathrm{a}}$ série do ensino fundamental regular e do ensino fundamental especial $=1,05$

NA1a4= número de alunos da $1^{\mathrm{a}}$ à $4^{\mathrm{a}}$ série do ensino fundamental regular do município ou governo estadual

ENM1a4= estimativa de novas matriculas da $1^{\mathrm{a}}$ à $4^{\mathrm{a}}$ série do ensino fundamental regular do município ou governo estadual $=$ zero

$\mathbf{N A 5 a 8}=$ número de alunos da $5^{\mathrm{a}}$ à $8^{\mathrm{a}}$ série do ensino fundamental regular do município ou governo estadual

ENM5a8= estimativa de novas matriculas da $5^{\mathrm{a}}$ à $8^{\mathrm{a}}$ série do ensino fundamental regular do município ou governo estadual $=$ zero

$\mathbf{N A e}=$ número de alunos do ensino fundamental especial do município ou do governo estadual $\mathbf{E N M e}=$ estimativa de novas matriculas do ensino fundamental especial do município ou do governo estadual $=$ zero

TA1a4= total de alunos de $1^{\mathrm{a}}$ à $4^{\mathrm{a}}$ série do ensino fundamental regular no âmbito do estado TENM1a4 = total de estimativas de novas matrículas de $1^{\mathrm{a}}$ à $4^{\mathrm{a}}$ série do ensino fundamental regular no âmbito do estado $=$ zero

TA5a $=$ total de alunos de $5^{\mathrm{a}}$ à $8^{\mathrm{a}}$ série no âmbito do estado

TENM5a8 $=$ total de estimativas de novas matrículas de $5^{\mathrm{a}}$ à $8^{\mathrm{a}}$ série do ensino fundamental regular no âmbito do estado = zero

$\mathbf{T A e}=$ total de alunos do ensino fundamental especial no âmbito do estado

TENMe $=$ total de estimativas de novas matrículas no ensino fundamental especial no âmbito do estado $=$ zero

No âmbito de cada estado havia um valor anual por aluno com base na previsão de receita do FUNDEF e no número de alunos no ensino fundamental (regular e especial) das redes municipais e estaduais do ano anterior. O valor per capita era calculado de maneira que o 
valor referente aos alunos de $5^{\mathrm{a}}$ à $8^{\mathrm{a}}$ e da educação especial fosse $5 \%$ superior ao referente aos alunos de $1^{\mathrm{a}}$ à $4^{\mathrm{a}}$.

Como exemplo, suponha que o montante anual de recursos calculado do FUNDEF no âmbito de um dado estado num determinado ano fosse $\mathrm{R} \$ 90.000 .000,00$. Se o número total de alunos matriculados de $1^{\mathrm{a}}$ à $4^{\mathrm{a}}$ série nas redes públicas de ensino (municipais e estaduais) dentro deste estado fosse então 120.000 , de $5^{\mathrm{a}}$ à $8^{\mathrm{a}}$ fosse 80.000 e na modalidade educação especial fosse 2.000, o valor por aluno era calculado da seguinte maneira:

Valor por aluno /ano de $1^{\mathrm{a}}$ à $4^{\mathrm{a}}$ série $=\frac{R \$ 90.000 .000,00}{120.000+80.000+2.000}=R \$ 445,55$

Valor por aluno /ano de $5^{\mathrm{a}}$ à $8^{\mathrm{a}}$ série e Educação Especial

$=(1,05) * \mathrm{R} \$ 445,55$

$=\mathrm{R} \$ 467,82$

Desta forma, também era possível calcular o montante previsto do Fundo para cada município de acordo com o número de alunos matriculados na sua rede de ensino. Suponha, por exemplo, que num dado exercício do ano t um município dentro do estado dado acima possuísse 2.000 alunos matriculados de $1^{\mathrm{a}}$ à $4^{\mathrm{a}}$ série, 1.700 matriculados de $5^{\mathrm{a}}$ à $8^{\mathrm{a}}$ e 200 alunos na modalidade educação especial. $\mathrm{O}$ total de recursos que este município receberia do Fundo da Unidade Federada em que se encontra seria calculado previamente como:

$$
\begin{array}{r}
\mathrm{R} \$ 445,55 \times 2.000=\mathrm{R} \$ 891.100,00 \\
+\mathrm{R} \$ 467,82 \times 1.700=\mathrm{R} \$ 795.294,00 \\
\underline{\mathrm{R} \$ 467,82 \times 200=\mathrm{R} \$ 93.564,36}
\end{array}
$$

Receita anual do município $=\mathrm{R} \$ 1.779 .958,00$

Como dito anteriormente, foi estabelecido um valor anual mínimo por aluno / ano, a ser assegurado ao governo estadual e aos governos municipais localizados nos estados onde esta relação entre o total da receita estimada do Fundo e o total de alunos do ensino fundamental (redes estadual e municipal) fosse inferior a este valor mínimo ${ }^{27}$.

\footnotetext{
${ }^{27}$ Para 1997 esse valor foi estabelecido pela própria lei que regulamentou o FUNDEF. Em 1998 passou a ser fixado por meio de Decreto Federal e a partir de 2000 passou a ocorrer definindo-se valores diferenciados para as séries de $1^{\mathrm{a}}$ à $4^{\mathrm{a}}$ série e de $5^{\mathrm{a}}$ à $8^{\mathrm{a}}$ e Educação Especial. Os repasses da complementação da União tinham seus valores definidos no início de cada exercício (anualmente), em que os valores mensais eram calculados e publicados por meio da Portaria do Ministério da Fazenda. O valor do Fundo repassado mensalmente não equivalia a 1/12 do valor anual estimado no início do exercício, pois as previsões de receitas se alteram no decorrer do ano devido às variações nas receitas tributárias tanto da União quanto dos Estados. Os demais
} 
Quanto às regras de utilização dos recursos do FUNDEF, a mais importante delas foi aquela que estabeleceu que, no mínimo, 60\% dos recursos do Fundo deveriam ser destinados anualmente à remuneração dos profisssionais do magistério em efetivo exercício no ensino fundamental público (regular, especial, indígena, supletivo, inclusive alfabetização de adultos), englobando os professores e os profissionais que exercem atividade de suporte pedagógico como: direção ou administração escolar, planejamento, inspeção, supervisão e orientação educacional, em efetivo exercício. Isto valeria tanto para os profissionais integrantes do Regime Jurídico Único do estado ou município, quanto aos regidos pela Consolidação das Leis do Trabalho - CLT e aos formais e legalmente contratados em caráter temporário, na forma da legislação vigente (INEP, 2004, p.14). O restante dos recursos (de até $40 \%$ do total) deveriam ser direcionados para despesas diversas "para manutenção e desenvolvimento do ensino" 28 .

Portanto, o FUNDEF alterou profundamente o financiamento do ensino fundamental no país. Primeiramente, porque o seu desenho foi feito de modo a diminuir as disparidades de recursos existentes entre as escolas do ensino público dentro de cada estado, uma vez que passou a redistribuir os recursos entre estados e municípios de acordo com o número de alunos matriculados nas escolas de ensino fundamental sob responsabilidade de cada esfera pública. Além disso, passou a garantir uma homogeneidade de recursos maior entre as unidades da

recursos que compunham o FUNDEF eram creditados automaticamente na conta específica do Fundo no Banco do Brasil, a partir do seu valor efetivamente arrecadado, e a cada mês os depósitos se efetivavam nas mesmas datas de transferências para as contas estaduais e municipais das fontes originárias dos recursos que compunham o Fundo. Assim, os repasses do ICMS ocorriam semanalmente, os do FPE, FPM e IPI exportação ocorriam decenalmente (dias 10, 20 e 30 do mês) e a desoneração das exportações e complementação da União ocorriam ao final de cada mês. Os recursos do FUNDEF, antes de serem distribuídos, iam para o Banco do Brasil, que então realizava o rateio (por Governos do Estado e do Município) no âmbito de cada Estado separadamente, tendo como base os coeficientes de distribuição passados pelo MEC (INEP, 2004, p. 11).

${ }^{28}$ Estas despesas incluíam:

a) Remuneração e aperfeiçoamento do pessoal docente e dos profissionais de educação (como habilitação de professores leigos, formação continuada para os profissionais da educação, remuneração de pessoal em atividades técnico-administrativas etc .);

b)Aquisição, manutenção, construção e conservação das instalações e equipamentos necessários ao ensino (como a aquisição de imóveis, reformas, mobiliário necessário ao atendimento das necessidades do ensino, manutenção de equipamentos existentes, reforma de instalações físicas, etc);

c) Uso e manutenção de bens vinculados ao sistema de ensino (aluguel de imóveis e equipamentos, despesas com serviços de luz, água, comunicação, etc.)

d) Levantamentos estatísticos, estudos e pesquisas para o aprimoramento da qualidade e expansão do ensino;

e) Realização de atividades necessárias ao funcionamento do ensino (despesas com vigilância, limpeza,

conservação, aquisição de materiais como giz, papel, canetas, etc.);

f) Amortização e custeio de operações de crédito destinadas a atender ao disposto nos itens acima (quitação de empréstimos realizados para investimentos em educação);

g) Aquisição de material didático escolar e manutenção de transporte escolar. 
federação e Distrito Federal, uma vez que estabeleceu um gasto nacional mínimo por aluno, ficando o governo federal responsável por realizar repasses sempre que este gasto mínimo não fosse atendido. E, por fim, vinculou $60 \%$ dos recursos provenientes do Fundo a gastos com salários dos professores do ensino fundamental.

\subsection{Metodologia}

Para se avaliar os impactos do FUNDEF sobre os diversos indicadores educacionais de interesse, neste trabalho será utilizada a metodologia de Diferenças em Diferenças aplicada em Card (1990) e descrita em Angrist e Krueger (1999). A abordagem é similar àquela utilizada por Andrade et al.. (2007) na análise dos impactos do FUNDEF sobre a taxa de reprovação dos alunos, bem como a de Menezes-Filho e Pazello (2007) na estimação dos impactos do Fundo sobre os salários dos professores e o aprendizado dos alunos.

No caso mais simples de aplicação de Diferenças em Diferenças, tem-se dois períodos de tempo, $t_{1}$ e $t_{2}$, e dois grupos de comparação, um grupo de tratamento e outro de controle. Idealmente, as unidades de observação se encontram em um dos dois grupos por acidente, e uma mudança exógena na variável explicativa de interesse, que afete apenas o grupo de tratamento, permite a identificação de um efeito causal desta sobre a variável dependente. Os dois períodos de tempo marcam antes e depois de ocorrida a mudança exógena na variável causal.

Como nas aplicações empíricas a aleatoriedade dos grupos nem sempre é observada, um importante componente desta estratégia de identificação é a escolha do grupo de controle que, de preferência, deve apresentar a mesma tendência que o grupo de tratamento no que diz respeito à evolução da variável dependente antes da mudança. Assim, é possível identificar o efeito causal da variável de interesse.

Para formalizar este raciocínio, a equação mais simples para se analisar o impacto da mudança de política pode ser escrita como $^{29}$ :

\footnotetext{
${ }^{29}$ Ver Wooldridge (2002, p. 128-132).
} 


$$
\begin{array}{r}
\mathrm{y}_{\mathrm{it}}=\beta_{0}+\beta_{1} \cdot \mathrm{d} 2+\beta_{2 .} \mathrm{dB}+\delta_{1}(\mathrm{~d} 2 . \mathrm{dB})+\mathrm{u}_{\mathrm{it}} \\
i \in A \cup B, \mathrm{t}=1,2,
\end{array}
$$

Denominando-se A o grupo de controle, B o grupo de tratamento, dB a variável dummy igual a um para as observações no grupo de tratamento (e zero caso contrário) e d2 a variável dummy igual a um no segundo período de tempo $t_{2}$ após a mudança de política, em (4.1) y it é a variável resposta de interesse da unidade de observação i no tempo $t$ e $u_{i t}$ é o erro idiossincrático. A dummy de tempo d2 captura fatores conjuntos no tempo que afetam y da mesma maneira para os dois grupos (A e B) e a dummy dB captura possíveis diferenças entre os grupos de controle e tratamento antes da mudança de política. O coeficiente de interesse neste caso é $\delta_{1}$, que capta o efeito da interação entre o tempo 2 e o grupo de tratamento B (o produto d2.dB é igual a um apenas para o grupo de tratamento no tempo seguinte à mudança ocorrida).

Sendo $\bar{y}_{A 1}$ a média da variável resposta y no grupo de controle A no tempo $1, \bar{y}_{A 2}$ a média da variável resposta y no grupo de controle A no tempo $2, \bar{y}_{B 1}$ a média da variável resposta no grupo de tratamento B no tempo 1 e $\bar{y}_{B 2}$ a média da variável resposta no grupo de tratamento B no tempo 2, o estimador por mínimos quadrados ordinários de $\delta_{1}$ pode ser expresso como:

$$
\hat{\delta}_{1 O L S}=\left(\bar{y}_{B 2}-\bar{y}_{B 1}\right)-\left(\bar{y}_{A 2}-\bar{y}_{A 1}\right)
$$

O estimador por mínimos quadrados ordinários de $\delta_{1}, \hat{\delta}_{1 O L S}$, é denominado o estimador de diferenças em diferenças. Comparando-se as mudanças no tempo das médias condicionais dos grupos de tratamento e controle, permite-se a existência de efeitos específicos de grupo e de tempo. Porém, para que o estimador de diferenças em diferenças seja não viesado, é preciso que a mudança de política não seja sistematicamente relacionada a outros fatores que afetam $y$ e se encontram em $u$. Ou seja, requer-se a hipótese de identificação:

$$
\mathrm{E}[\mathrm{u} / s, t]=0
$$

Em (4.3) u é o vetor de componentes $\mathrm{u}_{\mathrm{it}}, s$ indica o status de controle (A) ou tratamento (B) e $t$ indica o momento no tempo, antes ou depois da mudança de política. 
É possível incluir variáveis de controle adicionais na equação de estimação por diferenças em diferenças. Isto faz com que possíveis diferenças sistemáticas nas amostras dentro de um grupo nos diferentes períodos de tempo não sejam confundidas com um possível efeito do tratamento. A equação de regressão ajustada pelo vetor px1 de características individuais $\mathrm{X}_{\mathrm{it}}$ pode ser escrita como:

$$
\begin{array}{r}
\mathrm{y}_{\mathrm{it}}=\beta_{0}+\beta_{1} \cdot \mathrm{d} 2+\beta_{2} \cdot \mathrm{dB}+\delta_{1} \cdot(\mathrm{d} 2 \cdot \mathrm{dB})+\beta_{3} \cdot \mathrm{X}_{\mathrm{it}}+\mathrm{u}_{\mathrm{it}} \\
i \in A \cup B, \mathrm{t}=1,2, \quad \beta_{3} \text { vetor } 1 \mathrm{xp}
\end{array}
$$

A inclusão do vetor $X_{\text {it }}$ só irá alterar a estimação de $\delta_{1}$ se a interação (d2.dB) for correlacionada com $\mathrm{X}_{\mathrm{it}}$, dados os efeitos de tempo e de status. Por fim, cabe ressaltar que, na prática, $\delta_{1}$ pode diferir para diferentes períodos pós-tratamento (ANGRIST e KRUEGER, 1999).

No caso dos impactos do FUNDEF sobre os diversos indicadores educacionais que se pretende analisar, foram ajustados quatro modelos de Efeitos Fixos que levam em conta os efeitos específicos não-observados dos municípios. Supõe-se que estes efeitos específicos não se alterem no tempo, e que eles podem estar correlacionados com as demais variáveis explicativas. O primeiro destes modelos de Efeitos Fixos de município é representado pela equação (4.5):

$$
\overline{Y_{i r t}}=\alpha_{i}+\sum_{j=1}^{4} \beta_{j} \cdot \mathrm{d}_{1997+2 j}+d_{\mathrm{r}}+\sum_{j=1}^{4} \delta_{j} \cdot\left(\mathrm{d}_{1997+2 \mathrm{j}} \cdot \mathrm{d}_{\mathrm{r}}\right)+\mathrm{u}_{\mathrm{it}}
$$

$i=1 \ldots 2.837$.

$\mathrm{t}=1997,1999,2001,2003,2005$.

$\mathrm{r}=$ indicador de rede pública ou privada

Em (4.5) a variável dependente $\overline{Y_{i r t}}$ é a média para o município $i$ do indicador educacional de interesse $Y$ na rede de escolas $r$ no tempo $t ; \alpha_{i}$ é o efeito específico do município $i$ que não varia no tempo; $\boldsymbol{\beta}=\left(\beta_{1} \beta_{2} \beta_{3} \beta_{4}\right)^{\prime}$ é um vetor $4 \times 1$ que capta o efeito das dummies de ano (1999, 2001, 2003, 2005) após a entrada em vigor do FUNDEF (o ano de referência é 1997, antes da entrada em vigor da lei que criou o Fundo); $d_{\mathrm{r}}$ é uma dummy para rede escolar que é igual a um no caso de $\bar{Y}$ se referir à rede pública (escolas municipais), e zero no caso de $\bar{Y}$ 
se referir à rede privada; $\boldsymbol{\delta}=\left(\delta_{1} \delta_{2} \delta_{3} \delta_{4}\right)^{\prime}$ é um vetor $4 \times 1$ que capta o efeito da interação das dummies de ano $(1999,2001,2003,2005)$ com a dummy de rede $d_{\mathrm{r}}$. Neste caso, supondo que todas as escolas públicas (municipais, neste caso), tenham reagido à implantação do Fundef depois de 1998 (por exemplo buscando aumentar suas matrículas), $\boldsymbol{\delta}=\left(\delta_{1} \delta_{2} \delta_{3} \delta_{4}\right)^{\prime}$ é o vetor de parâmetros de interesse, uma vez que capta o "efeito FUNDEF" nas escolas municipais.

Porém, nem todas as escolas públicas municipais se beneficiaram com as novas regras estabelecidas pelo FUNDEF, pois alguns municípios perderam recursos, nos anos aqui analisados (ver Tabela 22). Por este motivo foram estimados outros três modelos de Efeitos Fixos, cada um com um tipo de variável adicional visando melhor captar o efeito-Fundef.

No segundo modelo de Efeitos Fixos ajustado, procura-se saber se os resultados sobre os indicadores educacionais são afetados pelo valor líquido por aluno que o município dispõe, em determinado ano, em termos de receitas menos despesas advindas do FUNDEF. Para tanto, inclui-se em (4.5) um segundo conjunto de interações, e o modelo estimado passa a ser representado pela equação (4.6):

$$
\overline{Y_{i r t}}=\alpha_{i}+\sum_{j=1}^{4} \beta_{j} \cdot \mathrm{d}_{1997+2 j}+d_{\mathrm{r}}+\sum_{j=1}^{4} \delta_{j} \cdot\left(\mathrm{d}_{1997+2 \mathrm{j}} \cdot \mathrm{d}_{\mathrm{r}}\right)+\sum_{j=1}^{4} \lambda_{j} \cdot\left(\mathrm{d}_{1997+2 \mathrm{j}} \cdot \mathrm{d}_{\mathrm{r}} \cdot V_{i t}\right)+\mathrm{u}_{\mathrm{it}}
$$

$i=1 \ldots 2.837$.

$\mathrm{t}=1997,1999,2001,2003,2005$.

$\mathrm{r}=$ indicador de rede pública ou privada

Em (4.6) o vetor $\lambda=\left(\lambda_{1} \lambda_{2} \lambda_{3} \lambda_{4}\right)^{\prime}$ capta o efeito da interação entre as dummies de ano, a dummy de rede, que é igual a um apenas no caso de escolas públicas, e o termo $V_{i t}$, que é o valor líquido do FUNDEF (dividido por mil) por aluno que o município $i$ dispõe no ano $t^{30}$. O efeito-FUNDEF passa a depender então também deste valor, e é representado por $\left(\boldsymbol{\lambda}+\boldsymbol{\delta} . V_{i t}\right)$.

No terceiro modelo de Efeitos Fixos, inclui-se na regressão (4.5) a interação $\left(\mathrm{d}_{1997+2 \mathrm{j}} \cdot \mathrm{d}_{\mathrm{r}} \cdot G_{i t}\right)$, em que $\mathrm{G}_{\text {it }}$ é uma dummy igual a um se o município $i$ ganhou recursos do FUNDEF no ano t, e

\footnotetext{
${ }^{30}$ Lembrar que no ano de 1997 não existia FUNDEF e, portanto, $\mathrm{V}_{\mathrm{i} 1997}=0$.
} 
igual a zero caso contrário. Neste caso, o grupo de tratamento passa a ser apenas as escolas municipais dos municípios que receberam transferência positiva do Fundo, e o grupo de controle as escolas municipais cujos municípios não perderam e nem ganharam com o fundo, as escolas particulares, e as escolas municipais cujos municípios perderam recursos para o Fundo. A equação (4.7) representa este modelo:

$$
\overline{Y_{i r t}}=\alpha_{i}+\sum_{j=1}^{4} \beta_{j} \cdot \mathrm{d}_{1997+2 j}+d_{\mathrm{r}}+\sum_{j=1}^{4} \delta_{j} \cdot\left(\mathrm{d}_{1997+2 \mathrm{j}} \cdot \mathrm{d}_{\mathrm{r}}\right)+\sum_{j=1}^{4} \theta_{j} \cdot\left(\mathrm{d}_{1997+2 \mathrm{j}} \cdot \mathrm{d}_{\mathrm{r}} \cdot G_{i t}\right)+\mathrm{u}_{\mathrm{it}}
$$

$i=1 \ldots 2.837$.

$\mathrm{t}=1997,1999,2001,2003,2005$.

$\mathrm{r}=$ indicador de rede pública ou privada

Em (4.7) o vetor $\boldsymbol{\theta}=\left(\theta_{1} \theta_{2} \theta_{3} \theta_{4}\right)^{\prime}$ capta o efeito que a interação entre as dummies de ano, dummy de rede e a dummy $\mathrm{G}_{\mathrm{it}}$, que é igual a um se o município $i$ ganhou recursos do FUNDEF no ano t e igual a zero caso contrário. Os parâmetros de interesse correspondentes ao efeito-FUNDEF neste caso são representados pelo vetor $4 \times 1 \mathbf{\theta}=\left(\theta_{1} \theta_{2} \theta_{3} \theta_{4}\right)^{\prime}$.

Por fim, como forma de verificar se as escolas privadas dos municípios são realmente adequadas como grupo de controle para o as escolas públicas em geral, e também para as escolas públicas beneficiados pelo FUNDEF em particular, ajusta-se um quarto modelo de Efeitos Fixos excluindo-se da amostra as escolas privadas. Neste caso, o grupo de tratamento consiste das escolas públicas nos municípios que ganharam com o Fundo $\left(\mathrm{G}_{\mathrm{it}}=1\right)$ e o grupo de controle é dado pelas escolas públicas dos municípios que perderam recursos com o Fundo $\left(\mathrm{G}_{\mathrm{it}}=0\right)$. A equação estimada neste caso é dada por:

$$
\overline{Y_{i t}}=\alpha_{i}+\sum_{j=1}^{4} \beta_{j} \cdot \mathrm{d}_{1997+2 j}+\sum_{j=1}^{4} \theta_{j} \cdot\left(\mathrm{d}_{1997+2 \mathrm{j}} \cdot G_{i t}\right)+\mathrm{u}_{\mathrm{it}}
$$

$i=1 \ldots 2.473$.

$\mathrm{t}=1997,1999,2001,2003,2005$.

Os parâmetros de interesse do efeito-Fundef nos diferentes anos são representados pelo vetor $4 \times 1 \quad \boldsymbol{\theta}=\left(\theta_{1} \theta_{2} \theta_{3} \theta_{4}\right)^{\prime}$. 


\subsection{Dados}

Os dados referente às características das escolas dos municípios que entraram neste estudo vieram do Censo Escolar, que é realizado anualmente pelo Instituto Nacional de Estudos e Pesquisas Educacionais (INEP/MEC), em parceria com os governos estaduais (secretarias estaduais de educação) e prefeituras municipais. Ele contém informações sobre características das escolas, como insumos de produção e infra-estrutura, composição do corpo docente em termos de modalidade de ensino, níveis de instrução dos professores, desempenho acadêmico dos alunos (apenas no que diz respeito a taxas de aprovação e reprovação), número de matrículas e turmas nos diferentes turnos entre outras.

Os dados sobre as matrículas são levantados entre os meses de março e abril de cada ano e consolidados por estado, no âmbito das secretarias estaduais de educação, processados no INEP e publicados no Diário Oficial da União. Depois da publicação dos dados preliminares (entre os meses de setembro e outubro) os estados e municípios têm o prazo de 30 dias para apresentação de recursos com vistas à retificação de dados eventualmente incorretos. No final de Novembro de cada ano, os dados do Censo Escolar são publicados de forma definitiva ${ }^{31}$.

Os dados sobre as receitas e contribuições dos municípios ao Fundo a partir de 1998, bem como o montante líquido de recursos do FUNDEF ao final de cada exercício, podem ser obtidos a partir da base de dados do Ministério da Fazenda denominada "Finanças do Brasil dados contábeis dos municípios", conhecida também como FINBRA. Ela contém dados da execução orçamentária (receitas e despesas) e do balanço patrimonial (ativo e passivo) para cada município, bem como os dados consolidados por estados e para o Brasil (ver MINISTÉRIO DA FAZENDA, 2008).

A cobertura da FINBRA não é completa e, ao se juntar às informações sobre os recursos do FUNDEF que cada município recebeu com aquelas provenientes do Censo Escolar, perderamse algumas observações de municípios que não constavam no mesmo ano na base da FINBRA. A Tabela 17 mostra a cobertura da FINBRA comparativamente à do IBGE.

\footnotetext{
${ }^{31}$ Depois de sua publicação definitiva no Diário Oficial da União, os dados sobre as matrículas eram então utilizados para o cálculo dos coeficientes de distribuição dos recursos do FUNDEF para o ano seguinte (INEP, 2004, p.8).
} 
Tabela 17-Cobertura dos municípios na FINBRA

\begin{tabular}{cccc}
\hline Ano & Municípios FINBRA & Municípios IBGE & Grau de cobertura FINBRA \\
\hline 1999 & 4.322 & 5.505 & $78,51 \%$ \\
2001 & 5.339 & 5.559 & $96,04 \%$ \\
2003 & 5.012 & 5.558 & $90,18 \%$ \\
2005 & 4.355 & 5.562 & $78,30 \%$ \\
\hline
\end{tabular}

Fonte: FINBRA

A Tabela 18, sem seguida, traz o número de municípios e escolas na base de dados resultante da junção das informações do Censo Escolar com aquelas da FINBRA.

Tabela 18-Número de municípios, escolas e grau de cobertura

\begin{tabular}{cccc}
\hline ano & Municípios & Escolas & Grau de cobertura* \\
\hline 1999 & 4.137 & 207.552 & $77,83 \%$ \\
2001 & 5.057 & 253.184 & $95,63 \%$ \\
2003 & 4.756 & 230.276 & $90,86 \%$ \\
2005 & 4.148 & 197.024 & $79,40 \%$ \\
\hline
\end{tabular}

Fonte: cálculos a partir do Censo Escolar e FINBRA

* Relativamente à base original do Censo Escolar

A Tabela 19 mostra o número de municípios no banco de dados que receberam transferência líquida positiva do FUNDEF, bem como o percentual de escolas na amostra que se encontravam nesses municípios para cada ano.

Tabela 19-Municípios e escolas com transferências líquidas positivas do FUNDEF

\begin{tabular}{ccc}
\hline Ano & Municípios & \% Escolas do Censo* \\
\hline 1999 & 2.034 & $64,43(47,87)$ \\
2001 & 2.659 & $69,84(69,84)$ \\
2003 & 3.113 & $80,96(39,25)$ \\
2005 & 2.453 & $39,98(48,98)$ \\
\hline
\end{tabular}

Para realizar as estimações foi preciso fazer alguns cortes no banco original do Censo Escolar. Em primeiro lugar ficou-se apenas com as escolas que oferecem ensino fundamental, pois este foi o nível de ensino alvo do FUNDEF. Foram excluídas as escolas que apresentavam código de funcionamento "Extinto" ou "Paralisado", ficando-se apenas com as escolas com o código descrito como "Ativo" e que apresentavam "numero de matrículas no ensino fundamental" maior ou igual a dez alunos. Foram excluídas também as escolas que apresentavam a variável "número do professores no ensino fundamental” igual a zero, indício de erro na computação 
dos dados. Além disso, excluíram-se as escolas das redes "estadual" e "federal". A Tabela 20 mostra o número de escolas em cada ano que entraram no painel de municípios.

Tabela 20-Número de escolas na amostra

\begin{tabular}{cccc}
\hline Ano & $\begin{array}{c}\text { Total de } \\
\text { Escolas }\end{array}$ & $\begin{array}{c}\text { Escolas } \\
\text { municipais }\end{array}$ & $\begin{array}{c}\text { Escolas } \\
\text { Privadas }\end{array}$ \\
\hline 1997 & 78.176 & 65.151 & 13.025 \\
1999 & 75.737 & 62.841 & 12.896 \\
2001 & 73.520 & 60.134 & 13.386 \\
2003 & 70.244 & 56.517 & 13.727 \\
2005 & 57.207 & 44.062 & 13.145 \\
\hline
\end{tabular}

As características das escolas foram agregadas, para sua média ou proporção, para o nível dos municípios, de acordo com o ano e a rede de ensino a que se referiam (se escola municipal ou particular), e foi montado um painel alanceado de municípios com dados dos anos 1997, 1999, 2001, 2003 e 2005. Neste ficaram apenas os municípios para os quais havia informações do Censo Escolar e FINBRA para todos os anos do painel, contabilizando 2.837 municípios. A partir desta base de dados foram calculados, para os diversos indicadores educacionais de interesse, o estimador de diferenças em diferenças do efeito-FUNDEF de acordo com a equação (4.2) e também ajustados os quatro modelos de Efeitos Fixos representados por (4.5), (4.6), (4.7) e (4.8).

A Tabela 21 mostra as estatísticas descritivas das variáveis dependentes que entraram nas regressões relacionadas aos "insumos" das escolas (ao nível de município): total de matrículas no ensino fundamental; razão do número de alunos no ensino fundamental pelo total de professores no ensino fundamental; total de professores no ensino fundamental; proporção de escolas com laboratório de ciências, laboratório de informática, quadra de esportes, biblioteca; proporção de professores no ensino fundamental de $1^{\text {a }}$ a $4^{\mathrm{a}}$ série com o $3^{\mathrm{o}}$ grau completo e proporção de professores no ensino fundamental de $5^{\mathrm{a}}$ a $8^{\mathrm{a}}$ série com o $3^{\mathrm{o}}$ grau completo. 
Tabela 21-Insumos das escolas de ensino fundamental do painel de municípios 1997-2005

\begin{tabular}{|c|c|c|c|c|c|c|c|c|c|}
\hline \multirow{2}{*}{$\begin{array}{l}\text { Variáveis de } \\
\text { Insumos }\end{array}$} & \multicolumn{3}{|c|}{ Todas as escolas } & \multicolumn{3}{|c|}{ Escolas municipais } & \multicolumn{3}{|c|}{ Escolas privadas } \\
\hline & Média & Min. & Máx. & Média & Min. & Máx. & Média & Min. & Máx. \\
\hline Matrículas & $\begin{array}{r}27.642,20 \\
(84.728,58)\end{array}$ & 10 & 618.830 & $\begin{array}{r}20.993,12 \\
(83.281,71)\end{array}$ & 10 & 618.830 & $\begin{array}{r}56.648,69 \\
(84.883,83)\end{array}$ & 10 & 300.335 \\
\hline $\begin{array}{l}\text { Razão } \\
\text { aluno/professor }\end{array}$ & $\begin{array}{r}21,69 \\
(10,75)\end{array}$ & 0,51 & 158 & $\begin{array}{r}23,48 \\
(10,49)\end{array}$ & 0,51 & 158 & $\begin{array}{r}13,92 \\
(8,11)\end{array}$ & 0,53 & 123 \\
\hline $\begin{array}{l}\text { Total de } \\
\text { professores }\end{array}$ & $\begin{array}{r}1.398,99 \\
(4.232,57)\end{array}$ & 1 & 28.129 & $\begin{array}{r}859,47 \\
(3.533,46)\end{array}$ & 1 & 28.129 & $\begin{array}{r}3.752,67 \\
(5.898,35)\end{array}$ & 1,00 & 19.984 \\
\hline $\begin{array}{l}\text { Laboratório de } \\
\text { ciências }\end{array}$ & $\begin{array}{r}0,08 \\
(0,28)\end{array}$ & 0 & 1 & $\begin{array}{r}0,02 \\
(0,16)\end{array}$ & 0 & 1 & $\begin{array}{r}0,34 \\
(0,47)\end{array}$ & 0 & 1 \\
\hline $\begin{array}{l}\text { Laboratório de } \\
\text { informática }\end{array}$ & $\begin{array}{r}0,14 \\
(0,34)\end{array}$ & 0 & 1 & $\begin{array}{r}0,05 \\
(0,21)\end{array}$ & 0 & 1 & $\begin{array}{r}0,53 \\
(0,50)\end{array}$ & 0 & 1 \\
\hline $\begin{array}{l}\text { Quadra de } \\
\text { esportes }\end{array}$ & $\begin{array}{r}0,22 \\
(0,41)\end{array}$ & 0 & 1 & $\begin{array}{r}0,14 \\
(0,34)\end{array}$ & 0 & 1 & $\begin{array}{r}0,58 \\
(0,49)\end{array}$ & 0 & 1 \\
\hline Biblioteca & $\begin{array}{r}0,26 \\
(0,44)\end{array}$ & 0 & 1 & $\begin{array}{r}0,15 \\
(0,36)\end{array}$ & 0 & 1 & $\begin{array}{r}0,74 \\
(0,44)\end{array}$ & 0 & 1 \\
\hline $\begin{array}{l}\text { Professores de } \\
1^{\mathrm{a}} \text { a } 4^{\mathrm{a}} \text { com } 3^{\mathrm{o}} \\
\text { grau }\end{array}$ & $\begin{array}{r}0,16 \\
(0,27)\end{array}$ & 0 & 1 & $\begin{array}{r}0,14 \\
(0,27)\end{array}$ & 0 & 1 & $\begin{array}{r}0,22 \\
(0,26)\end{array}$ & 0 & 1 \\
\hline $\begin{array}{l}\text { Professores de } \\
5^{\mathrm{a}} \text { a } 8^{\mathrm{a}} \operatorname{com} 3^{\mathrm{o}} \\
\text { grau }\end{array}$ & $\begin{array}{r}0,12 \\
(0,25)\end{array}$ & 0 & 1 & $\begin{array}{r}0,07 \\
(0,19)\end{array}$ & 0 & 1 & $\begin{array}{r}0,33 \\
(0,33)\end{array}$ & 0 & 1 \\
\hline
\end{tabular}

Fonte: cálculos próprios a partir do Censo Escolar e FINBRA. Notas: Desvio padrão em parênteses. Total de municípios desta amostra: 2.837 .

Na Tabela 21 pode-se notar grandes diferenças entre os indicadores educacionais das escolas municipais e privadas. Claramente as escolas particulares, em geral, possuem bem mais recursos ou insumos escolares que as escolas municipais.

A Tabela 22 traz as estatísticas descritivas para o mesmo conjunto de variáveis dependentes relacionadas aos insumos das escolas, porém para a subamostra utilizada na estimação do modelo (4.8). Neste caso, o universo de escolas são apenas escolas municipais, que se dividem entre os grupos de tratamento e controle "municípios que ganharam recursos do FUNDEF" e "municípios que perderam recursos ou obtiveram receitas líquidas do FUNDEF iguais a zero", respectivamente. O total de municípios que compõem esta amostra é 2.473. 
Tabela 22-Insumos das escolas municipais apenas para aquelas que ganharam ou perderam recursos do FUNDEF (1997-2005)

\begin{tabular}{|c|c|c|c|c|c|c|c|c|c|}
\hline Variáveis & \multicolumn{3}{|c|}{$\begin{array}{c}\text { Total de as escolas } \\
\text { municipais }\end{array}$} & \multicolumn{3}{|c|}{$\begin{array}{l}\text { Escolas em municípios que } \\
\text { ganharam recursos }\end{array}$} & \multicolumn{3}{|c|}{$\begin{array}{l}\text { Escolas em municípios que } \\
\text { perderam recursos }\end{array}$} \\
\hline Matrículas & $\begin{array}{l}\text { Média } \\
12.500,90 \\
(51.891,93)\end{array}$ & $\begin{array}{c}\text { Min. } \\
10\end{array}$ & $\begin{array}{l}\text { Máx. } \\
554.628\end{array}$ & $\begin{array}{l}\text { Média } \\
13.021,35 \\
(54.227,86)\end{array}$ & $\begin{array}{c}\text { Min. } \\
11\end{array}$ & $\begin{array}{l}\text { Máx. } \\
554.628\end{array}$ & $\begin{array}{l}\text { Média } \\
11.871,36 \\
(48.910,40)\end{array}$ & $\begin{array}{c}\text { Min. } \\
10\end{array}$ & $\begin{array}{l}\text { Máx. } \\
549.091\end{array}$ \\
\hline $\begin{array}{l}\text { Razão aluno/ } \\
\text { Professor }\end{array}$ & $\begin{array}{c}23,68 \\
(10,72)\end{array}$ & 0,51 & 158 & $\begin{array}{c}24,34 \\
(10,65)\end{array}$ & 1,17 & 138 & $\begin{array}{c}22,89 \\
(10,74)\end{array}$ & 0,51 & 158 \\
\hline $\begin{array}{l}\text { Total de } \\
\text { professores }\end{array}$ & $\begin{array}{c}476,88 \\
(1.953,45)\end{array}$ & 1 & 21.541 & $\begin{array}{c}497,56 \\
(2.058,51)\end{array}$ & 1 & 21.082 & $\begin{array}{c}451,86 \\
(1.817,97)\end{array}$ & 1 & 21.541 \\
\hline $\begin{array}{l}\text { Laboratório de } \\
\text { ciências }\end{array}$ & $\begin{array}{c}0,02 \\
(0,14)\end{array}$ & 0 & 1 & $\begin{array}{c}0,02 \\
(0,13)\end{array}$ & 0 & 1 & $\begin{array}{c}0,02 \\
(0,15)\end{array}$ & 0 & 1 \\
\hline $\begin{array}{l}\text { Laboratório de } \\
\text { informática }\end{array}$ & $\begin{array}{c}0,04 \\
(0,20)\end{array}$ & 0 & 1 & $\begin{array}{c}0,04 \\
(0,20)\end{array}$ & 0 & 1 & $\begin{array}{c}0,04 \\
(0,21)\end{array}$ & 0 & 1 \\
\hline $\begin{array}{l}\text { Quadra de } \\
\text { esportes }\end{array}$ & $\begin{array}{c}0,12 \\
(0,33)\end{array}$ & 0 & 1 & $\begin{array}{c}0,12 \\
(0,32)\end{array}$ & 0 & 1 & $\begin{array}{c}0,13 \\
(0,34)\end{array}$ & 0 & 1 \\
\hline Biblioteca & $\begin{array}{c}0,13 \\
(0,34)\end{array}$ & 0 & 1 & $\begin{array}{c}0,12 \\
(0,32)\end{array}$ & 0 & 1 & $\begin{array}{c}0,14 \\
(0,35)\end{array}$ & 0 & 1 \\
\hline $\begin{array}{l}\text { Professores de } \\
1^{\mathrm{a}} \text { a } 4^{\mathrm{a}} \operatorname{com} 3^{\circ} \\
\text { grau }\end{array}$ & $\begin{array}{c}0,13 \\
(0,26)\end{array}$ & 0 & 1 & $\begin{array}{c}0,11 \\
(0,24)\end{array}$ & 0 & 1 & $\begin{array}{c}0,18 \\
(0,30)\end{array}$ & 0 & 1 \\
\hline $\begin{array}{l}\text { Professores de } \\
5^{\mathrm{a}} \text { a } 8^{\mathrm{a}} \operatorname{com} 3^{\circ} \\
\text { grau }\end{array}$ & $\begin{array}{c}0,06 \\
(0,18)\end{array}$ & 0 & 1 & $\begin{array}{c}0,06 \\
(0,17)\end{array}$ & 0 & 1 & $\begin{array}{c}0,08 \\
(0,20)\end{array}$ & 0 & 1 \\
\hline
\end{tabular}

Fonte: cálculos próprios a partir do Censo Escolar e FINBRA. Desvio padrão em parênteses. Total de municípios desta amostra: 2.473 .

Na Tabela 22 nota-se que os dois grupos de observação (tratamento e controle) não apresentam diferenças significativas no que diz respeito à média dos indicadores educacionais de interesse.

A Tabela 23 reporta as taxas de fluxo e rendimento escolar para o universo de escolas que compõe o painel 1996-2005, bem como para escolas municipais e privadas separadamente. Nota-se que a taxa média de aprovação no ensino fundamental é superior nas escolas privadas relativamente às municipais, tanto no nível primário ( $1^{\mathrm{a}} \mathrm{a} 4^{\mathrm{a}}$ série $)$ quanto no ginasial $\left(5^{\mathrm{a}} \mathrm{a} 8^{\mathrm{a}}\right.$ série). Além disso, as escolas privadas possuem taxas de reprovação e abandono bem inferiores às das escolas municipais. Em termos de indicadores de qualidade, portanto, em média as escolas privadas apresentam desempenho muito superior às escolas municipais.

A Tabela 24 reporta as taxas de fluxo e rendimento escolar para a subamostra de escolas municipais apenas, que ganharam ou perderam recursos do FUNDEF no período 1996-2005. Neste caso, em termos destes indicadores de qualidade médios, a princípio não parece haver 
uma diferença significativa entre os grupos de controle e tratamento. $\mathrm{O}$ total de municípios que compõem esta amostra é 2.473 .

Tabela 23-Rendimento e fluxo escolar das escolas municipais e privadas (1997-2005)

\begin{tabular}{lccc}
\hline Variáveis (\%) & $\begin{array}{c}\text { Média todas } \\
\text { as escolas }\end{array}$ & $\begin{array}{c}\text { Média escolas } \\
\text { municipais }\end{array}$ & $\begin{array}{c}\text { Média escolas } \\
\text { Privadas }\end{array}$ \\
\hline Aprovação de $1^{\mathrm{a}}$ a 4 ${ }^{\mathrm{a}}$ série (\%) & 76,54 & 72,36 & 95,47 \\
& $(20,69)$ & $(20,02)$ & $(10,69)$ \\
Aprovação de $5^{\mathrm{a}}$ a $8^{\mathrm{a}}$ série (\%) & 84.89 & 78,48 & 93,68 \\
& $(14,82)$ & $(15,02)$ & $(8,84)$ \\
Aprovação do ensino fundamental (\%) & 76,38 & 72,28 & 94,45 \\
& $(20,30)$ & $(19,73)$ & $(10,61)$ \\
Reprovação de $1^{\mathrm{a}}$ a 4 $4^{\mathrm{a}}$ série (\%) & 14,07 & 16,54 & 2,86 \\
& $(14,02)$ & $(13,92)$ & $(7,44)$ \\
Reprovação de $5^{\mathrm{a}}$ a $8^{\mathrm{a}}$ série (\%) & 8,09 & 10,41 & 4,92 \\
& $(8,74)$ & $(9,34)$ & $(6,65)$ \\
Reprovação no ensino fundamental (\%) & 13,95 & 16,28 & 3,73 \\
& $(13,69)$ & $(13,74)$ & $7,29)$ \\
Abandono de $1^{\mathrm{a}}$ a 4 $4^{\mathrm{a}}$ série (\%) & 9,39 & 11,09 & 1,66 \\
& $(13,59)$ & $(14,09)$ & $(6,98)$ \\
Abandono de $5^{\mathrm{a}}$ a $8^{\mathrm{a}}$ série (\%) & 7,01 & 11,10 & 1,39 \\
& $(10,84)$ & $(11,97)$ & $(5,24)$ \\
Abandono no ensino fundamental (\%) & 9,66 & 11,44 & 1,82 \\
& $(13,49)$ & $(13,96)$ & $(7,00)$ \\
\hline
\end{tabular}

Fonte: cálculos a partir Censo escolar (INEP). Desvio padrão em parênteses.

Tabela 24-Rendimento e fluxo escolar das escolas municipais apenas

\begin{tabular}{|c|c|c|c|}
\hline Variáveis (\%) & $\begin{array}{l}\text { Média todas } \\
\text { as escolas } \\
\text { municipais }\end{array}$ & $\begin{array}{l}\text { Média das escolas que } \\
\text { Ganharam recursos }\end{array}$ & $\begin{array}{l}\text { Média das escolas que } \\
\text { perderam recursos }\end{array}$ \\
\hline Aprovação de $1^{\mathrm{a}}$ a $4^{\mathrm{a}}$ série (\%) & $\begin{array}{c}71,42 \\
(20,19)\end{array}$ & $\begin{array}{c}71,74 \\
(19,13)\end{array}$ & $\begin{array}{c}71,03 \\
(21,42)\end{array}$ \\
\hline Aprovação de $5^{\mathrm{a}}$ a $8^{\mathrm{a}}$ série (\%) & $\begin{array}{c}78,27 \\
(15,27)\end{array}$ & $\begin{array}{c}78,19 \\
(14,98)\end{array}$ & $\begin{array}{c}78,37 \\
(15,65)\end{array}$ \\
\hline Aprovação no ensino fundamental (\%) & $\begin{array}{l}71,36 \\
(19,93)\end{array}$ & $\begin{array}{l}71,10 \\
(18,85)\end{array}$ & $\begin{array}{l}70,94 \\
(21,18)\end{array}$ \\
\hline Reprovação de $1^{\mathrm{a}}$ a $4^{\mathrm{a}}$ série (\%) & $\begin{array}{c}17,03 \\
(14,09)\end{array}$ & $\begin{array}{c}17,24 \\
(13,72)\end{array}$ & $\begin{array}{c}16,77 \\
(14,51)\end{array}$ \\
\hline Reprovação de $5^{\mathrm{a}}$ a $8^{\mathrm{a}}$ série (\%) & $\begin{array}{l}10,40 \\
(9,46)\end{array}$ & $\begin{array}{l}10,04 \\
(9,19)\end{array}$ & $\begin{array}{l}10,89 \\
(9,80)\end{array}$ \\
\hline Reprovação no ensino fundamental (\%) & $\begin{array}{c}16,76 \\
(13,92)\end{array}$ & $\begin{array}{c}16,89 \\
(13,54)\end{array}$ & $\begin{array}{c}16,59 \\
(14,37)\end{array}$ \\
\hline Abandono de $1^{\mathrm{a}}$ a $4^{\mathrm{a}}$ série $(\%)$ & $\begin{array}{l}11,55 \\
(14,37)\end{array}$ & $\begin{array}{c}11,01 \\
(13,18)\end{array}$ & $\begin{array}{l}12,19 \\
(15,68)\end{array}$ \\
\hline Abandono de $5^{\mathrm{a}}$ a $8^{\mathrm{a}}$ série $(\%)$ & $\begin{array}{c}11,33 \\
(12,24)\end{array}$ & $\begin{array}{l}11,76 \\
(12,07)\end{array}$ & $\begin{array}{c}10,73 \\
(12,45)\end{array}$ \\
\hline Abandono no ensino fundamental (\%) & $\begin{array}{c}11,89 \\
(14,25)\end{array}$ & $\begin{array}{c}11,41 \\
(13,08)\end{array}$ & $\begin{array}{l}12,47 \\
(15,54)\end{array}$ \\
\hline
\end{tabular}

Fonte: cálculos a partir do Censo escolar (INEP). Desvio padrão em parênteses.

Municípios desta amostra: 2.473 . 


\subsection{Resultados}

\subsubsection{Matrículas no ensino fundamental}

Nesta seção do trabalho investiga-se os impactos do FUNDEF sobre as matrículas no ensino fundamental com o uso dos diferentes modelos de equações. A Tabela 25 traz o resultado da estimação da equação (4.2) para a obtenção do estimador de Diferenças em Diferenças do efeito-FUNDEF sobre a média de matrículas no ensino fundamental nas escolas públicas. Neste caso o efeito do Fundo se mostrou positivo e significante em todos os anos.

Tabela 25-Estimador DD da equação (4.2) para log(matrículas)

\begin{tabular}{rrrr}
\hline & Pública & Privada & Diferença \\
$\mathbf{1 9 9 7}$ & 6,806 & 5,866 & 0,940 \\
Diferença & 7,158 & 5,709 & 1,449 \\
Desvio Padrão & 0,352 & $-0,157$ & $0,509 * * *$ \\
& & & $(0,071)$ \\
\cline { 4 - 4 } $\mathbf{1 9 9 7}$ & Pública & Privada & Diferença \\
$\mathbf{2 0 0 1}$ & 7,806 & 5,866 & 0,940 \\
Diferença & 0,398 & 5,716 & 1,488 \\
Desvio Padrão & & $-0,15$ & $0,548 * * *$ \\
& Pública & Privada & Diferença \\
$\mathbf{1 9 9 7}$ & 6,806 & 5,866 & 0,940 \\
$\mathbf{2 0 0 3}$ & 7,247 & 5,732 & 1,515 \\
Diferença & 0,441 & $-0,134$ & $0,575^{* * *}$ \\
Desvio Padrão & & & $(0,069)$ \\
\hline & Pública & Privada & Diferença \\
1997 & 6,806 & 5,866 & 0,940 \\
$\mathbf{2 0 0 5}$ & 7,09 & 5,697 & 1,393 \\
Desvios padrões em parênteses. Grau de significância: *10\%, $* * 5 \%, * * 1 \%$
\end{tabular}

De acordo com as estimações reportadas na Tabela 25, tendo como base o ano de 1997 as escolas municipais da amostra apresentaram um crescimento no número de matrículas do ensino fundamental superior ao das escolas privadas, em todo o período analisado. Isto pode ter decorrido de outros fatores, como a municipalização do ensino e a elevada repetência relativa observada nas escolas públicas (ver Tabela 23). Pode ser que a municipalização tenha contribuído para este diferencial nas matrículas, mas é de se esperar que as escolas privadas também tenham captado alunos neste processo. Quanto à importância que as taxas de fluxo e rendimento escolar desempenharam, porém, observa-se que a taxa de abandono também é 
superior nas escolas municipais (o que tenderia a diminuir o número de matrículas decorrentes da manipulação das taxas de reprovação), mas esta questão será analisada com mais detalhe na seção 4.5.4.

Tabela 26-Estimações por efeito fixo de município para log (matrículas)

\begin{tabular}{|c|c|c|c|c|}
\hline Variáveis & Modelo 1 & Modelo 2 & Modelo 3 & Modelo 4 \\
\hline D_1999 & $\begin{array}{r}-0,102 * * * \\
(0,024)\end{array}$ & $\begin{array}{c}-0,102 * * * \\
(0,024)\end{array}$ & $\begin{array}{r}-0,103 * * * \\
(0,024)\end{array}$ & $\begin{array}{r}0,284 * * * \\
(0,013)\end{array}$ \\
\hline D_2001 & $\begin{array}{r}-0,052 * * \\
(0,024)\end{array}$ & $\begin{array}{c}-0,052 * * \\
(0,024)\end{array}$ & $\begin{array}{r}-0,054^{* *} \\
(0,024)\end{array}$ & $\begin{array}{r}0,328 * * * \\
(0,013)\end{array}$ \\
\hline D_2003 & $\begin{array}{r}-0,013 \\
(0,024)\end{array}$ & $\begin{array}{l}-0,013 \\
(0,024)\end{array}$ & $\begin{array}{r}-0,014 \\
(0,024)\end{array}$ & $\begin{array}{r}0,375 * * * \\
(0,015)\end{array}$ \\
\hline D_2005 & $\begin{array}{r}-0,013 \\
(0,024)\end{array}$ & $\begin{array}{l}-0,013 \\
(0,024)\end{array}$ & $\begin{array}{r}-0,014 \\
(0,024)\end{array}$ & $\begin{array}{r}0,345^{* * *} \\
(0,014)\end{array}$ \\
\hline Publica & $\begin{array}{r}1,806 * * * \\
(0,022)\end{array}$ & $\begin{array}{c}1,804 * * * \\
(0,021)\end{array}$ & $\begin{array}{r}1,793 * * * \\
(0,022)\end{array}$ & - \\
\hline dpub1999 & $\begin{array}{r}0,438 * * * \\
(0,030)\end{array}$ & $\begin{array}{c}0,480 * * * \\
(0,029)\end{array}$ & $\begin{array}{r}0,263 * * * \\
(0,032)\end{array}$ & - \\
\hline dpub2001 & $\begin{array}{r}0,434 * * * \\
(0,030)\end{array}$ & $\begin{array}{c}0,445 * * * \\
(0,029)\end{array}$ & $\begin{array}{r}0,273 * * * \\
(0,032)\end{array}$ & - \\
\hline dpub2003 & $\begin{array}{r}0,438 * * * \\
(0,030)\end{array}$ & $\begin{array}{c}0,434 * * * \\
(0,029)\end{array}$ & $\begin{array}{r}0,247 * * * \\
(0,035)\end{array}$ & - \\
\hline dpub2005 & $\begin{array}{r}0,376^{* * * *} \\
(0,030)\end{array}$ & $\begin{array}{c}0,384 * * * \\
(0,029)\end{array}$ & $\begin{array}{r}0,323 * * * \\
(0,034)\end{array}$ & - \\
\hline Dpub.99.V & - & $\begin{array}{c}0,166^{* * *} \\
(0,008)\end{array}$ & - & - \\
\hline Dpub.01.V & - & $\begin{array}{c}0,033 * * * \\
(0,004)\end{array}$ & - & - \\
\hline Dpub.03.V & - & $\begin{array}{c}0,067 * * * \\
(0,007)\end{array}$ & - & - \\
\hline Dpub.05.V & - & $\begin{array}{c}-0,002 * * * \\
(0,000)\end{array}$ & - & - \\
\hline Dpub.99.G & - & - & $\begin{array}{r}0,337 * * * \\
(0,026)\end{array}$ & $\begin{array}{r}0,051 * * * \\
(0,016)\end{array}$ \\
\hline Dpub.01.G & - & - & $\begin{array}{r}0,308^{* * *} * \\
(0,026)\end{array}$ & $\begin{array}{r}0,053 * * * \\
(0,016)\end{array}$ \\
\hline Dpub.03.G & - & - & $\begin{array}{r}0,284 * * * \\
(0,028)\end{array}$ & $\begin{array}{r}0,034^{* *} \\
(0,017)\end{array}$ \\
\hline Dpub.05.G & - & - & $\begin{array}{r}0,089 * * * \\
(0,028)\end{array}$ & $\begin{array}{r}-0,024 \\
(0,016)\end{array}$ \\
\hline Constante & $\begin{array}{c}5,266^{* * *} \\
(0,030)\end{array}$ & $\begin{array}{c}5,267 * * * \\
(0,017)\end{array}$ & $\begin{array}{r}5,275^{* * *} * \\
(0,017)\end{array}$ & $\begin{array}{r}6,750 * * * \\
(0,007)\end{array}$ \\
\hline Obs & 21.031 & 21.031 & 21.031 & 12.365 \\
\hline Grupos & 2.837 & 2.837 & 2.837 & 2.473 \\
\hline R2 within & 0,699 & 0,707 & 0,705 & 0,173 \\
\hline R2between & 0,069 & 0,052 & 0,046 & 0,376 \\
\hline R2 overall & 0,173 & 0,185 & 0,191 & 0,024 \\
\hline
\end{tabular}

Desvios padrões em parênteses. Grau de significância: *10\%, ** 5\%, ***1\% 
Para aprofundar a análise sobre o papel que o FUNDEF exerceu sobre as matrículas no ensino fundamental, a Tabela 26 traz as estimações realizadas por Efeitos Fixos de municípios das diferentes especificações, modelos 1, 2 , 3 e 4, dadas pelas equações (4.5), (4.6), (4.7) e (4.8).

A Tabela 26 mostra que o "efeito-FUNDEF" foi positivo e significativo em todos os modelos ajustados de Efeitos Fixos e em todos os períodos pós tratamento, à exceção do parâmetro da interação "Dpub.05.V" no modelo 2. Nota-se que mesmo entre as escolas municipais apenas (modelo 4), houve um aumento das matrículas decorrente no do "efeito-FUNDEF". Neste caso, contudo, o sinal do parâmetro da variável de interação "Dpub.05.G” também deu negativo, porém não significante.

\subsubsection{Insumos escolares}

\subsubsection{Razão alunos /professor}

A Tabela 27 mostra o estimador de Diferenças em Diferenças da equação (4.2) para a variável dependente "razão de alunos por professor" no ensino fundamental. A princípio parece ter havido um aumento da razão alunos por professor nas escolas municipais relativamente às escolas privadas. Este resultado se confirma nas estimações por efeitos fixos dos modelos 1 , 2, 3 e 4 (Tabela 28).

Tabela 27- Estimador DD da equação (4.2) para log (razão alunos/ professor)

\begin{tabular}{|c|c|c|c|}
\hline & Pública & Privada & Diferença \\
\hline 1997 & 2,93 & 2,468 & 0,462 \\
\hline 1999 & 3,004 & 2,333 & 0,671 \\
\hline \multirow{3}{*}{$\begin{array}{l}\text { Diferença } \\
\text { Desvio Padrão }\end{array}$} & 0,074 & $-0,135$ & $0,209 * * *$ \\
\hline & & & $(0,018)$ \\
\hline & Pública & Privada & Diferença \\
\hline 1997 & 2,93 & 2,468 & 0,462 \\
\hline 2001 & 2,942 & 2,291 & 0,651 \\
\hline \multirow{3}{*}{$\begin{array}{l}\text { Diferença } \\
\text { Desvio Padrão }\end{array}$} & 0,012 & $-0,177$ & $0,189 * * *$ \\
\hline & & & $(0,017)$ \\
\hline & Pública & Privada & Diferença \\
\hline 1997 & 2,93 & 2,468 & 0,462 \\
\hline 2003 & 2,9 & 2,251 & 0,649 \\
\hline \multirow{3}{*}{$\begin{array}{l}\text { Diferença } \\
\text { Desvio Padrão }\end{array}$} & $-0,03$ & $-0,217$ & $0,187 * * *$ \\
\hline & & & $(0,017)$ \\
\hline & Pública & Privada & Diferença \\
\hline 1997 & 2,93 & 2,468 & 0,462 \\
\hline 2005 & 2,816 & 2,226 & 0,590 \\
\hline $\begin{array}{l}\text { Diferença } \\
\text { Desvio Padrão }\end{array}$ & $-0,114$ & $-0,242$ & $\begin{array}{c}0,128 * * * \\
(0,018)\end{array}$ \\
\hline
\end{tabular}

Desvios padrões em parênteses. Grau de significância: *10\%, ** 5\%, ***1\% 
Tabela 28-Estimações por efeito fixo de município para log(razão alunos /professor)

\begin{tabular}{|c|c|c|c|c|}
\hline Variáveis & Modelo 1 & Modelo 2 & Modelo 3 & Modelo 4 \\
\hline \multirow[t]{2}{*}{ D_1999 } & $-0,119 * * *$ & $-0,119 * * *$ & $-0,119 * * *$ & $0,051 * * *$ \\
\hline & $(0,010)$ & $(0,010)$ & $(0,010)$ & $(0,007)$ \\
\hline \multirow[t]{2}{*}{ D_2001 } & $-0,154 * * *$ & $-0,154 * * *$ & $-0,154 * * *$ & $-0,001$ \\
\hline & $(0,010)$ & $(0,010)$ & $(0,010)$ & $(0,007)$ \\
\hline \multirow[t]{2}{*}{ D_2003 } & $-0,191 * * *$ & $-0,191 * * *$ & $-0,191 * * *$ & $-0,036 * * *$ \\
\hline & $(0,010)$ & $(0,010)$ & $(0,010)$ & $(0,008)$ \\
\hline \multirow[t]{2}{*}{ D_2005 } & $-0,213 * * *$ & $-0,213 * * *$ & $-0,213 * * *$ & $-0,146 * * *$ \\
\hline & $(0,010)$ & $(0,010)$ & $(0,010)$ & $(0,007)$ \\
\hline \multirow[t]{2}{*}{ Publ } & $0,559 * * *$ & $0,558 * * *$ & $0,558 * * *$ & - \\
\hline & $(0,010)$ & $(0,009)$ & $(0,009)$ & \\
\hline \multirow[t]{2}{*}{ dpub1999 } & $0,191 * * *$ & $0,193 * * *$ & $0,178 * * *$ & - \\
\hline & $(0,009)$ & $(0,012)$ & $(0,013)$ & \\
\hline \multirow[t]{2}{*}{ dpub2001 } & $0,164 * * *$ & $0,164 * * *$ & $0,156^{* * *}$ & - \\
\hline & $(0,012)$ & $(0,012)$ & $(0,013)$ & \\
\hline \multirow[t]{2}{*}{ dpub2003 } & $0,159 * * *$ & $0,159 * * *$ & $0,164 * * *$ & - \\
\hline & $(0,012)$ & $(0,012)$ & $(0,014)$ & \\
\hline \multirow[t]{2}{*}{ dpub2005 } & $0,090 * * *$ & $0,092 * * *$ & $0,080 * * *$ & - \\
\hline & $(0,012)$ & $(0,012)$ & $(0,014)$ & \\
\hline \multirow[t]{2}{*}{ Dpub.99.V } & - & $0,009 * * *$ & - & - \\
\hline & & $(0,003)$ & & \\
\hline \multirow[t]{2}{*}{ Dpub.01.V } & - & 0,001 & - & - \\
\hline & & $(0,002)$ & & \\
\hline \multirow[t]{2}{*}{ Dpub.03.V } & - & 0,001 & - & - \\
\hline & & $(0,003)$ & & \\
\hline \multirow[t]{2}{*}{ Dpub.05.V } & - & $0,000 * *$ & - & - \\
\hline & & $(0,000)$ & & \\
\hline \multirow[t]{2}{*}{ Dpub.99.G } & - & - & $0,025 * *$ & $0,023 * * *$ \\
\hline & & & $(0,011)$ & $(0,008)$ \\
\hline \multirow[t]{2}{*}{ Dpub.01.G } & - & - & 0,015 & 0,002 \\
\hline & & & $(0,011)$ & $(0,008)$ \\
\hline \multirow[t]{2}{*}{ Dpub.03.G } & - & - & $-0,007$ & $-0,009$ \\
\hline & & & $(0,011)$ & $(0,009)$ \\
\hline \multirow[t]{2}{*}{ Dpub.05.G } & - & - & 0,017 & $0,017 * *$ \\
\hline & & & $(0,011)$ & $(0,008)$ \\
\hline \multirow[t]{2}{*}{ Constante } & $2,401 * * *$ & $2,401 * * *$ & $2,401 * * *$ & $2,947 * * *$ \\
\hline & $(0,007)$ & $(0,007)$ & $(0,007)$ & $(0,004)$ \\
\hline Obs & 21.031 & 21.031 & 21.031 & 12.365 \\
\hline Grupos & 2.837 & 2.837 & 2.837 & 2.473 \\
\hline R2 within & 0,607 & 0,607 & 0,607 & 0,147 \\
\hline R2between & 0,085 & 0,087 & 0,087 & 0,006 \\
\hline R2 overall & 0,396 & 0,397 & 0,397 & 0,035 \\
\hline
\end{tabular}

Nota-se, nos resultados da Tabela 28, que o efeito-FUNDEF de aumento da razão de alunos por professor se mostrou significante em todos os modelos apenas no primeiro ano após a entrada em vigor do Fundo (1999). Nos demais anos se mostrou não significativo, na maioria dos casos. Porém, este efeito não é bom, porque indica uma maior escassez de recursos advinda da implementação do Fundo. 


\subsubsection{2}

Laboratório de ciências

Também estimou-se o "efeito-Fundef" sobre a proporção de escolas com laboratório de ciências nos municípios. Para este caso, os parâmetros resultantes da estimação da equação (4.2) se mostraram não significativos, como mostra a Tabela 29.

Tabela 29- Estimador DD da equação (4.2) para "laboratório de ciências"

\begin{tabular}{|c|c|c|c|}
\hline & Pública & Privada & Diferença \\
\hline 1997 & 0,032 & 0,333 & $-0,301$ \\
\hline 1999 & 0,04 & 0,351 & $-0,311$ \\
\hline \multirow{3}{*}{$\begin{array}{l}\text { Diferença } \\
\text { Desvio Padrão }\end{array}$} & 0,008 & 0,018 & $-0,01$ \\
\hline & & & $(0,015)$ \\
\hline & Pública & Privada & Diferença \\
\hline 1997 & 0,032 & 0,333 & $-0,301$ \\
\hline 2001 & 0,037 & 0,353 & $-0,316$ \\
\hline \multirow{3}{*}{$\begin{array}{l}\text { Diferença } \\
\text { Desvio Padrão }\end{array}$} & 0,005 & 0,02 & $-0,015$ \\
\hline & & & $(0,015)$ \\
\hline & Pública & Privada & Diferença \\
\hline 1997 & 0,032 & 0,333 & $-0,301$ \\
\hline 2003 & 0,039 & 0,359 & $-0,32$ \\
\hline \multirow{3}{*}{$\begin{array}{l}\text { Diferença } \\
\text { Desvio Padrão }\end{array}$} & 0,007 & 0,026 & $-0,019$ \\
\hline & & & $(0,014)$ \\
\hline & Pública & Privada & Diferença \\
\hline 1997 & 0,032 & 0,333 & $-0,301$ \\
\hline 2005 & 0,047 & 0,354 & $-0,307$ \\
\hline \multirow{2}{*}{$\begin{array}{l}\text { Diferença } \\
\text { Desvio Padrão }\end{array}$} & 0,015 & 0,021 & $-0,006$ \\
\hline & & & $(0,014)$ \\
\hline
\end{tabular}

Já os resultados das estimações por efeitos fixos divergiram, como mostra a Tabela 30 De acordo com o modelo 1 (equação 4.5), o "efeito-Fundef", captado pelas interações de dummy de escola pública com dummies de ano, foi negativo e significativo apenas nos anos 2001 e 2003. No modelo 2 estas interações se mostraram também negativas, inclusive para o ano 2005, mas nos municípios que receberam um montante de recursos maior do fundo no ano de 1999 houve um aumento relativo na proporção de escolas municipais com laboratório de ciências. 
Tabela 30-Estimações de efeitos fixos de município para“laboratório de ciências"

\begin{tabular}{|c|c|c|c|c|}
\hline Variáveis & Modelo 1 & Modelo 2 & Modelo 3 & Modelo 4 \\
\hline \multirow[t]{2}{*}{ D_1999 } & $0,019 * *$ & $0,019 * *$ & $0,019^{* *}$ & 0,006 \\
\hline & $(0,007)$ & $(0,007)$ & $(0,007)$ & $(0,003)$ \\
\hline \multirow[t]{2}{*}{ D_2001 } & $0,023 * * *$ & $0,023 * * *$ & $0,023 * * *$ & 0,004 \\
\hline & $(0,007)$ & $(0,007)$ & $(0,007)$ & $(0,003)$ \\
\hline \multirow[t]{2}{*}{ D_2003 } & $0,033 * * *$ & $0,033 * * *$ & $0,033 * * *$ & 0,005 \\
\hline & $(0,007)$ & $(0,007)$ & $(0,007)$ & $(0,004)$ \\
\hline \multirow[t]{2}{*}{ D_2005 } & $0,031 * * *$ & $0,031 * * *$ & $0,031 * * *$ & $0,014 * * *$ \\
\hline & $(0,007)$ & $(0,007)$ & $(0,007)$ & $(0,003)$ \\
\hline \multirow[t]{2}{*}{ Publ } & $-0,282 * * *$ & $-0,282 * * *$ & $-0,283 * * *$ & - \\
\hline & $(0,007)$ & $(0,007)$ & $(0,007)$ & \\
\hline \multirow[t]{2}{*}{ dpub1999 } & $-0,012$ & $-0,009$ & $-0,031 * * *$ & - \\
\hline & $(0,009)$ & $(0,009)$ & $(0,010)$ & \\
\hline \multirow[t]{2}{*}{ dpub2001 } & $-0,020 * *$ & $-0,019 * *$ & $-0,040 * * *$ & - \\
\hline & $(0,009)$ & $(0,009)$ & $(0,010)$ & \\
\hline \multirow[t]{2}{*}{ dpub2003 } & $-0,027 * * *$ & $-0,028 * * *$ & $-0,051 * * *$ & - \\
\hline & $(0,009)$ & $(0,009)$ & $(0,011)$ & \\
\hline \multirow[t]{2}{*}{ dpub2005 } & $-0,016$ & $-0,016^{*}$ & $-0,037 * * *$ & - \\
\hline & $(0,009)$ & $(0,009)$ & $(0,010)$ & \\
\hline \multirow[t]{2}{*}{ Dpub.99.V } & - & $0,012 * * *$ & - & - \\
\hline & & $(0,003)$ & & \\
\hline \multirow[t]{2}{*}{ Dpub.01.V } & - & 0,002 & - & - \\
\hline & & $(0,001)$ & & \\
\hline \multirow[t]{2}{*}{ Dpub.03.V } & - & 0,002 & - & - \\
\hline & & $(0,002)$ & & \\
\hline \multirow[t]{2}{*}{ Dpub.05.V } & - & 0,000 & - & - \\
\hline & & $(0,000)$ & & \\
\hline \multirow[t]{2}{*}{ Dpub.99.G } & - & - & $0,036 * * *$ & 0,003 \\
\hline & & & $(0,008)$ & $(0,004)$ \\
\hline \multirow[t]{2}{*}{ Dpub.01.G } & - & - & $0,039 * * *$ & 0,003 \\
\hline & & & $(0,008)$ & $(0,004)$ \\
\hline \multirow[t]{2}{*}{ Dpub.03.G } & - & - & $0,035 * * *$ & 0,003 \\
\hline & & & $(0,009)$ & $(0,004)$ \\
\hline \multirow[t]{2}{*}{ Dpub.05.G } & - & - & $0,037 * * *$ & 0,006 \\
\hline & & & $(0,009)$ & $(0,004)$ \\
\hline \multirow[t]{2}{*}{ Constante } & $0,320 * * *$ & $0,320 * * *$ & $0,321 * * *$ & $0,031 * * *$ \\
\hline & $(0,005)$ & $(0,005)$ & $(0,005)$ & $(0,002)$ \\
\hline Obs & 21.031 & 21.031 & 21.031 & 12.365 \\
\hline Grupos & 2.837 & 2.837 & 2.837 & 2.473 \\
\hline R2 within & 0,319 & 0,320 & 0,322 & 0,005 \\
\hline R2between & 0,213 & 0,209 & 0,200 & 0,013 \\
\hline R2 overall & 0,260 & 0,259 & 0,257 & 0,000 \\
\hline
\end{tabular}

De acordo com as estimações no modelo 3, em que o grupo de tratamento são apenas as escolas municipais pertencentes a municípios que ganharam recursos com o Fundo e o grupo de controle são as escolas municipais de municípios com transferência líquida de recursos negativa além das escolas particulares, o efeito se mostrou positivo e significativo em todos os anos. O mesmo não ocorreu, porém, na estimação do modelo 4, que toma como grupo de controle apenas as escolas municipais naqueles municípios com transferência líquida de recursos iguais ou menores que zero. Neste caso parece não ter havido qualquer mudança 
relativa significativa na proporção de escolas municipais, que receberam transferência positiva, com laboratório de ciências.

\subsubsection{Laboratório de informática}

A Tabela 31 reporta as estimações da equação (4.2) para a variável dependente "laboratório de informática nas escolas". Pelos estimadores obtidos, a princípio, o FUNDEF teria reduzido os gastos com este tipo de insumo nas escolas. Pode ser que a subvinculação de $60 \%$ dos recursos do fundo a gastos obrigatoriamente com salários dos professores tenha causado esta redução. Mas os resultados das estimações por efeitos fixos da Tabela 33 apontam em direção contrária.

Tabela 31- Estimador DD da equação (4.2) para "laboratório de informática"

\begin{tabular}{|c|c|c|c|}
\hline & Pública & Privada & Diferença \\
\hline 1997 & 0,013 & 0,325 & $-0,312$ \\
\hline 1999 & 0,026 & 0,414 & $-0,388$ \\
\hline $\begin{array}{l}\text { Diferença } \\
\text { Desvio Padrão }\end{array}$ & 0,013 & 0,089 & $\begin{array}{r}-0,076^{* * *} * \\
(0,014)\end{array}$ \\
\hline & Pública & Privada & Diferença \\
\hline 1997 & 0,013 & 0,325 & $-0,312$ \\
\hline 2001 & 0,06 & 0,46 & $-0,4$ \\
\hline $\begin{array}{l}\text { Diferença } \\
\text { Desvio Padrão }\end{array}$ & 0,047 & 0,135 & $\begin{array}{r}-0,088^{* * *} * \\
(0,014)\end{array}$ \\
\hline & Pública & Privada & Diferença \\
\hline 1997 & 0,013 & 0,325 & $-0,312$ \\
\hline 2003 & 0,115 & 0,49 & $-0,375$ \\
\hline $\begin{array}{l}\text { Diferença } \\
\text { Desvio Padrão }\end{array}$ & 0,102 & 0,165 & $\begin{array}{r}-0,063 * * * \\
(0,015)\end{array}$ \\
\hline & Pública & Privada & Diferença \\
\hline 1997 & 0,013 & 0,325 & $-0,312$ \\
\hline 2005 & 0,167 & 0,496 & $-0,329$ \\
\hline $\begin{array}{l}\text { Diferença } \\
\text { Desvio Padrão }\end{array}$ & 0,154 & 0,171 & $\begin{array}{r}-0,017 \\
(0,017)\end{array}$ \\
\hline
\end{tabular}

Na Tabela 32, os modelos 2, 3 e 4 apontam que houve um aumento da proporção de escolas municipais com laboratório de informática naquelas que receberam recursos positivos do Fundo, relativamente às demais (privadas e municipais que perderam recursos). O resultado é mais robusto, se repetindo nos três modelos, para o caso do ano de 1999, ano em que a mudança foi mais exógena (ano em que se pode dizer que a mudança de política não foi antecipada pelos agentes). Além disso, comparando-se os parâmetros obtidos pelo modelo 1 mais simples com aqueles dos modelos 2 e 3, os demais parâmetros estimados (as dummies de 
tempo e as interações entre dummies de tempo e dummy de escola pública) praticamente não sofrem alterações de um modelo para o outro.

Tabela 32-Estimações de efeitos fixos de município para "laboratório de informática"

\begin{tabular}{|c|c|c|c|c|}
\hline Variáveis & Modelo 1 & Modelo 2 & Modelo 3 & Modelo 4 \\
\hline D_1999 & $\begin{array}{c}0,093 * * * \\
(0,009)\end{array}$ & $\begin{array}{c}0,093 * * * \\
(0,009)\end{array}$ & $\begin{array}{c}0,093 * * * \\
(0,009)\end{array}$ & $\begin{array}{c}-0,005 \\
(0,006)\end{array}$ \\
\hline D_2001 & $\begin{array}{c}0,140 * * * \\
(0,009)\end{array}$ & $\begin{array}{c}0,140 * * * \\
(0,009)\end{array}$ & $\begin{array}{c}0,140 * * * \\
(0,009)\end{array}$ & $\begin{array}{c}0,041^{* * *} \\
(0,006)\end{array}$ \\
\hline D_2003 & $\begin{array}{c}0,172 * * * \\
(0,009)\end{array}$ & $\begin{array}{c}0,172 * * * \\
(0,009)\end{array}$ & $\begin{array}{c}0,172 * * * \\
(0,009)\end{array}$ & $\begin{array}{c}0,119 * * * \\
(0,007)\end{array}$ \\
\hline D_2005 & $\begin{array}{c}0,182 * * * \\
(0,009)\end{array}$ & $\begin{array}{c}0,182 * * * \\
(0,009)\end{array}$ & $\begin{array}{c}0,182 * * * \\
(0,009)\end{array}$ & $\begin{array}{c}0,158 * * * \\
(0,006)\end{array}$ \\
\hline Publ & $\begin{array}{c}-0,288 * * * \\
(0,008)\end{array}$ & $\begin{array}{c}-0,288 * * * \\
(0,008)\end{array}$ & $\begin{array}{c}-0,289 * * * \\
(0,008)\end{array}$ & - \\
\hline dpub1999 & $\begin{array}{c}-0,083 * * * \\
(0,011)\end{array}$ & $\begin{array}{c}-0,080 * * * \\
(0,011)\end{array}$ & $\begin{array}{c}-0,115^{* * *} \\
(0,012)\end{array}$ & - \\
\hline dpub2001 & $\begin{array}{c}-0,097 * * * \\
(0,011)\end{array}$ & $\begin{array}{c}-0,096^{* * * *} \\
(0,011)\end{array}$ & $\begin{array}{c}-0,117 * * * \\
(0,012)\end{array}$ & - \\
\hline dpub2003 & $\begin{array}{c}-0,074 * * * \\
(0,011)\end{array}$ & $\begin{array}{c}-0,074 * * * \\
(0,011)\end{array}$ & $\begin{array}{c}-0,072 * * * \\
(0,013)\end{array}$ & - \\
\hline dpub2005 & $\begin{array}{c}-0,029 * * * \\
(0,011)\end{array}$ & $\begin{array}{c}-0,030 * * * \\
(0,011)\end{array}$ & $\begin{array}{c}-0,030 * * * \\
(0,012)\end{array}$ & - \\
\hline Dpub.99.V & - & $\begin{array}{c}0,012 * * * \\
(0,003)\end{array}$ & - & - \\
\hline Dpub.01.V & - & $\begin{array}{c}0,001 \\
(0,001)\end{array}$ & - & - \\
\hline Dpub.03.V & - & $\begin{array}{c}0,003 \\
(0,003)\end{array}$ & - & - \\
\hline Dpub.05.V & - & $\begin{array}{c}0,000 \\
(0,000)\end{array}$ & - & - \\
\hline Dpub.99.G & - & - & $\begin{array}{c}0,063 * * * \\
(0,009)\end{array}$ & $\begin{array}{r}0,036^{* * *} \\
(0,007)\end{array}$ \\
\hline Dpub.01.G & - & - & $\begin{array}{c}0,039 * * * \\
(0,010)\end{array}$ & $\begin{array}{r}0,010 \\
(0,007)\end{array}$ \\
\hline Dpub.03.G & - & - & $\begin{array}{c}-0,003 \\
(0,010)\end{array}$ & $\begin{array}{r}-0,029 * * * \\
(0,008)\end{array}$ \\
\hline Dpub.05.G & - & - & $\begin{array}{c}0,002 \\
(0,010)\end{array}$ & $\begin{array}{r}-0,015^{* *} \\
(0,007)\end{array}$ \\
\hline Constante & $\begin{array}{c}0,309 * * * \\
(0,006)\end{array}$ & $\begin{array}{c}0,019 * * * \\
(0,006)\end{array}$ & $\begin{array}{c}0,310^{* * *} \\
(0,006)\end{array}$ & $\begin{array}{r}0,013 * * * \\
(0,003)\end{array}$ \\
\hline Obs & 19.760 & 19.760 & 19.760 & 12.365 \\
\hline Grupos & 2.667 & 2.667 & 2.667 & 2.473 \\
\hline R2 within & 0,368 & 0,369 & 0,370 & 0,143 \\
\hline R2between & 0,272 & 0,267 & 0,257 & 0,002 \\
\hline R2 overall & 0,314 & 0,313 & 0,312 & 0,073 \\
\hline
\end{tabular}

\subsubsection{Biblioteca}

Os resultados da estimação de (4.2) para a variável dependente "proporção de escolas com biblioteca" apontam que o houve um aumento relativo das escolas municipais com bibliotecas considerando-se os anos 2001, 2003 e 2005 (Tabela 33). Na Tabela 34 as estimações por 
efeitos fixos do "efeito-FUNDEF" nos modelos 1 e 2 apontam que este aumento ocorreu em todo o período analisado: 1999, 2001, 2003 e 2005. Já as estimações pelos modelos 3 e 4 indicam que, nas escolas municipais daqueles municípios que receberam transferências positivas do Fundo, houve uma queda relativa da proporção de bibliotecas no ano de 2003 e um aumento desta proporção no ano 2005. Com relação aos demais anos, o efeito do Fundo foi não significativo de acordo com estes dois modelos. Como os parâmetros que o modelo 1 e 3 têm em comum não mudam muito de uma estimação para a outra, os resultados obtidos pelas estimações dos modelos 3 e 4 parecem ser os mais certeiros.

Tabela 33-Estimador DD da equação (4.2) para "biblioteca"

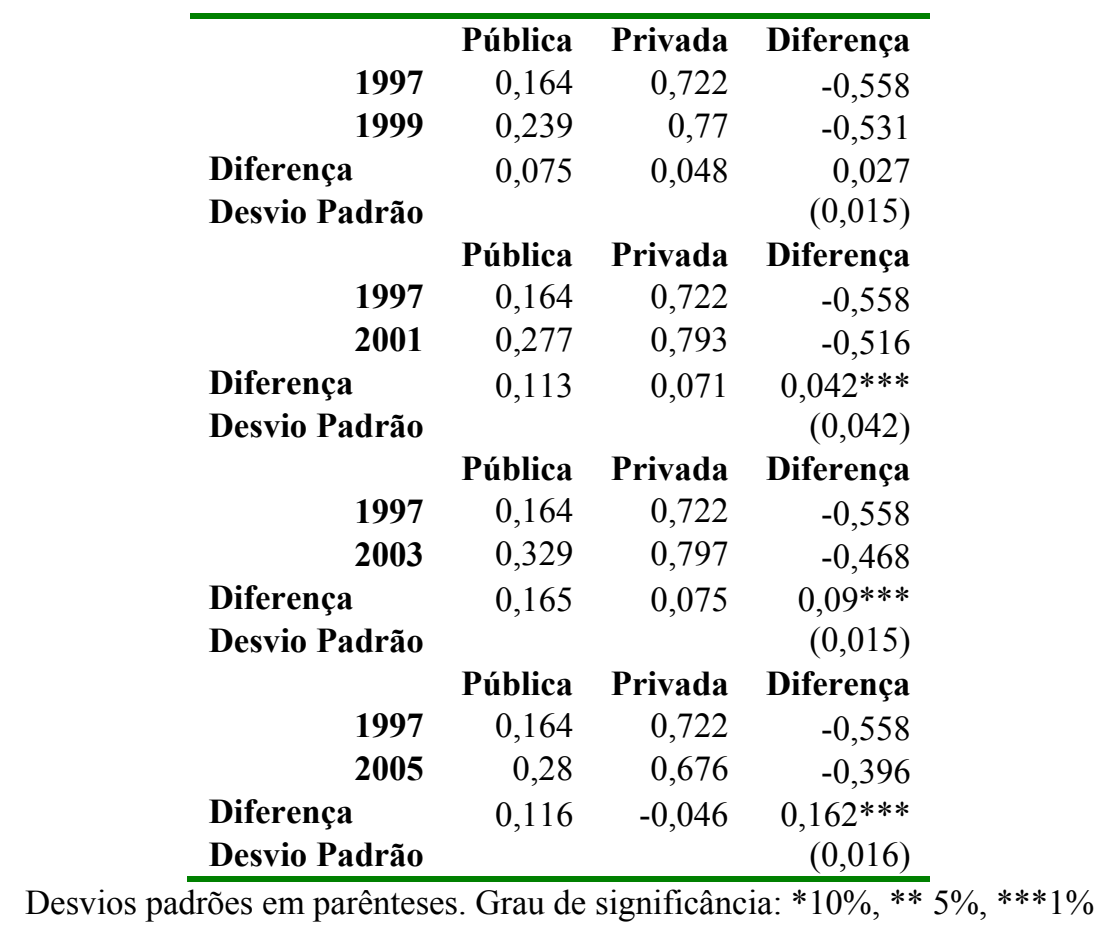


Tabela 34-Estimações por efeito fixo de município para "biblioteca"

\begin{tabular}{|c|c|c|c|c|}
\hline Variáveis & Modelo 1 & Modelo 2 & Modelo 3 & Modelo 4 \\
\hline \multirow[t]{2}{*}{ D_1999 } & $0,043 * * *$ & $0,043 * * *$ & $0,043 * * *$ & $0,065 * * *$ \\
\hline & $(0,009)$ & $(0,009)$ & $(0,009)$ & $(0,007)$ \\
\hline \multirow[t]{2}{*}{ D_2001 } & $0,070 * * *$ & $0,070 * * *$ & $0,070 * * *$ & $0,113 * * *$ \\
\hline & $(0,009)$ & $(0,009)$ & $(0,009)$ & $(0,007)$ \\
\hline \multirow[t]{2}{*}{ D_2003 } & $0,074 * * *$ & $0,074 * * *$ & $0,074 * * *$ & $0,182 * * *$ \\
\hline & $(0,009)$ & $(0,009)$ & $(0,009)$ & $(0,009)$ \\
\hline \multirow[t]{2}{*}{ D_2005 } & $-0,042 * * *$ & $-0,042 * * *$ & $-0,041 * * *$ & $0,106^{* * *}$ \\
\hline & $(0,009)$ & $(0,009)$ & $(0,009)$ & $(0,008)$ \\
\hline \multirow[t]{2}{*}{ Publ } & $-0,541 * * *$ & $-0,541 * * *$ & $-0,539 * * *$ & \\
\hline & $(0,008)$ & $(0,008)$ & $(0,008)$ & - \\
\hline \multirow[t]{2}{*}{ dpub1999 } & $0,031 * * *$ & $0,029 * * *$ & $0,034 * * *$ & \\
\hline & $(0,011)$ & $(0,011)$ & $(0,013)$ & - \\
\hline \multirow[t]{2}{*}{ dpub2001 } & $0,043 * * *$ & $0,044 * * *$ & $0,051 * * *$ & \\
\hline & $(0,011)$ & $(0,011)$ & $(0,012)$ & - \\
\hline \multirow[t]{2}{*}{ dpub2003 } & $0,090 * * *$ & $0,090 * * *$ & $0,120 * * *$ & \\
\hline & $(0,011)$ & $(0,011)$ & $(0,013)$ & - \\
\hline \multirow[t]{2}{*}{ dpub2005 } & $0,164 * * *$ & $0,163 * * *$ & $0,148 * * *$ & \\
\hline & $(0,011)$ & $(0,011)$ & $(0,013)$ & - \\
\hline \multirow[t]{2}{*}{ Dpub.99.V } & - & $-0,005$ & - & \\
\hline & & $(0,003)$ & & - \\
\hline \multirow[t]{2}{*}{ Dpub.01.V } & - & 0,004 & - & \\
\hline & & $(0,001)$ & & - \\
\hline \multirow[t]{2}{*}{ Dpub.03.V } & - & 0,000 & - & \\
\hline & & $(0,003)$ & & - \\
\hline \multirow[t]{2}{*}{ Dpub.05.V } & - & 0,000 & - & \\
\hline & & $(0,000)$ & & - \\
\hline \multirow[t]{2}{*}{ Dpub.99.G } & - & - & $-0,006$ & 0,007 \\
\hline & & & $(0,010)$ & $(0,009)$ \\
\hline \multirow[t]{2}{*}{ Dpub.01.G } & - & - & $-0,015$ & $-0,010$ \\
\hline & & & $(0,010)$ & $(0,009)$ \\
\hline \multirow[t]{2}{*}{ Dpub.03.G } & - & - & $-0,044 * * *$ & $-0,034 * * *$ \\
\hline & & & $(0,011)$ & $(0,010)$ \\
\hline \multirow[t]{2}{*}{ Dpub.05.G } & - & - & $0,027 * *$ & $0,029 * * *$ \\
\hline & & & $(0,011)$ & $(0,009)$ \\
\hline \multirow[t]{2}{*}{ Constante } & $0,711 * * *$ & $0,711 * * *$ & $0,710 * * *$ & $0,159 * * *$ \\
\hline & $(0,007)$ & $(0,007)$ & $(0,007)$ & $(0,004)$ \\
\hline Obs & 21.031 & 21.031 & 21.031 & 12.365 \\
\hline Grupos & 2.837 & 2.837 & 2.837 & 2.473 \\
\hline R2 within & 0,449 & 0,450 & 0,450 & 0,090 \\
\hline R2between & 0,222 & 0,221 & 0,228 & 0,008 \\
\hline R2 overall & 0,349 & 0,350 & 0,352 & 0,030 \\
\hline
\end{tabular}

\subsubsection{Quadra de esportes}

Procurou-se estudar também se o FUNDEF teria gerado incentivo para gastos com "quadra de esportes" nas escolas municipais. Os parâmetros estimados pelo método mais simples de 
diferenças em diferenças da equação (4.2) apontam que houve aumento relativo das escolas municipais com quadras de esporte em todos os anos analisados (Tabela 35).

Tabela 35- Estimador DD da equação (4.2) para "quadra de esportes"

\begin{tabular}{|c|c|c|c|}
\hline & Pública & Privada & Diferença \\
\hline 1997 & 0,146 & 0,483 & $-0,337$ \\
\hline 1999 & 0,19 & 0,492 & $-0,302$ \\
\hline \multirow{3}{*}{$\begin{array}{l}\text { Diferença } \\
\text { Desvio Padrão }\end{array}$} & 0,044 & 0,009 & $0,035 * *$ \\
\hline & & & $(0,016)$ \\
\hline & Pública & Privada & Diferença \\
\hline 1997 & 0,146 & 0,483 & $-0,337$ \\
\hline 2001 & 0,224 & 0,51 & $-0,286$ \\
\hline \multirow{3}{*}{$\begin{array}{l}\text { Diferença } \\
\text { Desvio Padrão }\end{array}$} & 0,078 & 0,027 & $0,051 * * *$ \\
\hline & & & $(0,017)$ \\
\hline & Pública & Privada & Diferença \\
\hline 1997 & 0,146 & 0,483 & $-0,337$ \\
\hline 2003 & 0,295 & 0,568 & $-0,273$ \\
\hline \multirow{3}{*}{$\begin{array}{l}\text { Diferença } \\
\text { Desvio Padrão }\end{array}$} & 0,149 & 0,085 & $0,064 * * *$ \\
\hline & & & $(0,017)$ \\
\hline & Pública & Privada & Diferença \\
\hline 1997 & 0,146 & 0,483 & $-0,337$ \\
\hline 2005 & 0,306 & 0,566 & $-0,26$ \\
\hline \multirow{2}{*}{$\begin{array}{l}\text { Diferença } \\
\text { Desvio Padrão }\end{array}$} & 0,16 & 0,083 & $0,077 * * *$ \\
\hline & & & $(0,017)$ \\
\hline
\end{tabular}

Os resultados das estimações pelos quatro modelos de efeitos fixos de município, reportados na Tabela 36, indicam que em 1999 houve realmente um aumento da proporção de escolas municipais com quadras de esporte. Como este é o ano em que a mudança de política foi mais exógena, este resultado parece ser o mais robusto. 
Tabela 36-Estimações por efeitos fixos de município para "quadras de esporte"

\begin{tabular}{|c|c|c|c|c|}
\hline Variáveis & Modelo 1 & Modelo 2 & Modelo 3 & Modelo 4 \\
\hline \multirow[t]{2}{*}{ D_1999 } & 0,009 & 0,009 & 0,009 & $0,029 * * *$ \\
\hline & $(0,009)$ & $(0,009)$ & $(0,009)$ & $(0,006)$ \\
\hline \multirow[t]{2}{*}{ D_2001 } & $0,035 * * *$ & $0,035 * * *$ & $0,035 * * *$ & $0,088 * * *$ \\
\hline & $(0,009)$ & $(0,009)$ & $(0,009)$ & $(0,006)$ \\
\hline \multirow[t]{2}{*}{ D_2003 } & $0,098 * * *$ & $0,098 * * *$ & $0,098 * * *$ & $0,162 * * *$ \\
\hline & $(0,009)$ & $(0,009)$ & $(0,009)$ & $(0,007)$ \\
\hline \multirow[t]{2}{*}{ D_2005 } & $0,100 * * *$ & $0,100 * * *$ & $0,100 * * *$ & $0,163 * * *$ \\
\hline & $(0,009)$ & $(0,009)$ & $(0,009)$ & $(0,006)$ \\
\hline \multirow[t]{2}{*}{ Publ } & $-0,304 * * *$ & $-0,304 * * *$ & $-0,304 *$ & \\
\hline & $(0,008)$ & $(0,008)$ & $(0,008)$ & - \\
\hline \multirow[t]{2}{*}{ dpub1999 } & $0,032 * * *$ & $0,035 * * *$ & $0,021 * * *$ & \\
\hline & $(0,011)$ & $(0,011)$ & $(0,012)$ & - \\
\hline \multirow[t]{2}{*}{ dpub2001 } & $0,040 * * *$ & $0,040 * * *$ & $0,039 * * *$ & \\
\hline & $(0,011)$ & $(0,011)$ & $(0,012)$ & - \\
\hline \multirow[t]{2}{*}{ dpub2003 } & $0,047 * * *$ & $0,047 * * *$ & $0,067 * * *$ & \\
\hline & $(0,011)$ & $(0,011)$ & $(0,013)$ & - \\
\hline \multirow[t]{2}{*}{ dpub2005 } & $0,053 * * *$ & $0,054 * * *$ & $0,061 * * *$ & \\
\hline & $(0,011)$ & $(0,011)$ & $(0,013)$ & - \\
\hline \multirow[t]{2}{*}{ Dpub.99.V } & - & $0,009 * * *$ & - & \\
\hline & & $(0,003)$ & & - \\
\hline \multirow[t]{2}{*}{ Dpub.01.V } & - & 0,001 & - & \\
\hline & & $(0,001)$ & & - \\
\hline \multirow[t]{2}{*}{ Dpub.03.V } & - & 0,001 & - & \\
\hline & & $(0,003)$ & & - \\
\hline \multirow[t]{2}{*}{ Dpub.05.V } & - & $0,000 *$ & - & \\
\hline & & $(0,000)$ & & - \\
\hline \multirow[t]{2}{*}{ Dpub.99.G } & - & - & $0,022 * *$ & $0,018 * *$ \\
\hline & & & $(0,010)$ & $(0,008)$ \\
\hline \multirow[t]{2}{*}{ Dpub.01.G } & - & - & 0,002 & $-0,006$ \\
\hline & & & $(0,010)$ & $(0,008)$ \\
\hline \multirow[t]{2}{*}{ Dpub.03.G } & - & - & $-0,030 * * *$ & $-0,031 * * *$ \\
\hline & & & $(0,011)$ & $(0,008)$ \\
\hline \multirow[t]{2}{*}{ Dpub.05.G } & - & - & $-0,015$ & $-0,018 * *$ \\
\hline & & & $(0,011)$ & $(0,008)$ \\
\hline \multirow[t]{2}{*}{ Constante } & $0,461 * * *$ & $0,461 * * *$ & $0,461 * * *$ & $0,148 * * *$ \\
\hline & $(0,007)$ & $(0,007)$ & $(0,007)$ & $(0,003)$ \\
\hline Obs & 21.031 & 21.031 & 21.031 & 11.230 \\
\hline Grupos & 2.837 & 2.837 & 2.837 & 2.246 \\
\hline R2 within & 0,239 & 0,239 & 0,239 & 0,104 \\
\hline R2between & 0,091 & 0,088 & 0,092 & 0,015 \\
\hline R2 overall & 0,159 & 0,158 & 0,160 & 0,032 \\
\hline
\end{tabular}

\subsubsection{Professores do ensino fundamental}

Com relação ao número de professores no ensino fundamental nos municípios, tanto a estimação por diferenças em diferenças simples, representada pela equação (4.2) (Tabela 37), quanto as estimações pelos modelos de efeitos fixos (Tabela 38), mostraram que houve um aumento no número de professores neste nível de ensino nas escolas municipais, em todos os anos analisados. 
Na Tabela 38 observa-se que todos os estimadores do "efeito_FUNDEF" nos modelos de efeitos fixos apresentaram sinais positivos e significantes entre $1 \%$ e $5 \%$, à exceção do estimador da variável "Dpub.05.V" no modelo 2 e da variável "Dpub.05.G" no modelo 4, que apresentaram sinais negativos e significantes a 1\%. No modelo 2, porém, o efeitoFUNDEF total depende da razão entre os recursos recebidos (ou repassados) do Fundo por aluno e da soma do estimador de "Dpub.05.V" com o da variável "Dpub.2005". Pode-se inferir, portanto, que o efeito do Fundo sobre a contratação de professores para o nível fundamental nas escolas municipais no período analisado como um todo, e no ano imediatamente posterior à sua entrada em vigor, em especial, foi de aumentar o número de professores.

Tabela 37- Estimador DD da equação (4.2) para "log ( professores no EF)"

\begin{tabular}{|c|c|c|c|}
\hline & Pública & Privada & Diferença \\
\hline 1997 & 3,796 & 3,330 & 0,460 \\
\hline 1999 & 4,079 & 3,308 & 0,770 \\
\hline \multirow{3}{*}{$\begin{array}{l}\text { Diferença } \\
\text { Desvio Padrão }\end{array}$} & 0,28 & $-0,03$ & $0,304 * * *$ \\
\hline & & & $(0,064)$ \\
\hline & Pública & Privada & Diferença \\
\hline 1997 & 3,796 & 3,33 & 0,466 \\
\hline 2001 & 4,177 & 3,359 & 0,818 \\
\hline \multirow{3}{*}{$\begin{array}{l}\text { Diferença } \\
\text { Desvio Padrão }\end{array}$} & 0,381 & 0,029 & $0,352 * * *$ \\
\hline & & & $(0,063)$ \\
\hline & Pública & Privada & Diferença \\
\hline 1997 & 3,796 & 3,330 & 0,460 \\
\hline 2003 & 4,257 & 3,420 & 0,830 \\
\hline \multirow{3}{*}{$\begin{array}{l}\text { Diferença } \\
\text { Desvio Padrão }\end{array}$} & 0,46 & 0,09 & $0,371 * * *$ \\
\hline & & & $(0,063)$ \\
\hline & Pública & Privada & Diferença \\
\hline 1997 & 3,796 & 3,33 & 0,460 \\
\hline 2005 & 4,186 & 3,414 & 0,770 \\
\hline \multirow{2}{*}{$\begin{array}{l}\text { Diferença } \\
\text { Desvio Padrão }\end{array}$} & 0,39 & 0,08 & $0,306^{* * *}$ \\
\hline & & & $(0,063)$ \\
\hline
\end{tabular}

Os resultados obtidos para o número de professores vão ao encontro dos resultados obtidos para o número de matrículas no ensino fundamental nos municípios (Tabelas 25 e 26) e aos obtidos para os efeitos do Fundo sobre a razão alunos/ professor ( Tabelas 27 e 28). Houve um aumento no número de matrículas mais que proporcional ao aumento no número de professores no ensino fundamental das escolas municipais. 
Tabela 38-Estimações por efeitos fixos de município para "log ( professores no EF)"

\begin{tabular}{|c|c|c|c|c|}
\hline Variáveis & Modelo 1 & Modelo 2 & Modelo 3 & Modelo 4 \\
\hline \multirow[t]{2}{*}{ D_1999 } & 0,016 & 0,016 & $0,015^{* * *}$ & $0,236^{* * *}$ \\
\hline & $(0,023)$ & $(0,022)$ & $(0,022)$ & $(0,012)$ \\
\hline \multirow[t]{2}{*}{ D_2001 } & $0,102 * * *$ & $0,102 * * *$ & $0,101 * * *$ & $0,327 * * *$ \\
\hline & $(0,023)$ & $(0,022)$ & $(0,022)$ & $(0,012)$ \\
\hline \multirow[t]{2}{*}{ D_2003 } & $0,183 * * *$ & $0,183 * * *$ & $0,182 * * *$ & $0,410 * * *$ \\
\hline & $(0,022)$ & $(0,022)$ & $(0,022)$ & $(0,015)$ \\
\hline \multirow[t]{2}{*}{ D_2005 } & $0,209 * * *$ & $0,210 * * *$ & $0,208 * * *$ & $0,482 * * *$ \\
\hline & $(0,022)$ & $(0,022)$ & $(0,022)$ & $(0,013)$ \\
\hline \multirow[t]{2}{*}{ Publ } & $1,219 * * *$ & $1,218 * * *$ & $1,206 * * *$ & - \\
\hline & $(0,022)$ & $(0,020)$ & $(0,020)$ & \\
\hline \multirow[t]{2}{*}{ dpub1999 } & $0,253 * * *$ & $0,293 * * *$ & $0,090 * * *$ & - \\
\hline & $(0,028)$ & $(0,027)$ & $(0,030)$ & \\
\hline \multirow[t]{2}{*}{ dpub2001 } & $0,266 * * *$ & $0,276 * * *$ & $0,112 * * *$ & - \\
\hline & $(0,028)$ & $(0,027)$ & $(0,030)$ & \\
\hline \multirow[t]{2}{*}{ dpub2003 } & $0,265 * * *$ & $0,261 * * *$ & $0,076 * * *$ & - \\
\hline & $(0,028)$ & $(0,027)$ & $(0,032)$ & \\
\hline \multirow[t]{2}{*}{ dpub2005 } & $0,266 * * *$ & $0,272 * * *$ & $0,233 * * *$ & - \\
\hline & $(0,028)$ & $(0,027)$ & $(0,031)$ & \\
\hline \multirow[t]{2}{*}{ Dpub.99.V } & - & $0,154 * * *$ & - & - \\
\hline & & $(0,008)$ & & \\
\hline \multirow[t]{2}{*}{ Dpub.01.V } & - & $0,032 * * *$ & - & - \\
\hline & & $(0,004)$ & & \\
\hline \multirow[t]{2}{*}{ Dpub.03.V } & - & $0,064 * * *$ & - & - \\
\hline & & $(0,007)$ & & \\
\hline \multirow[t]{2}{*}{ Dpub.05.V } & - & $-0,002 * * *$ & - & - \\
\hline & & $(0,000)$ & & \\
\hline \multirow[t]{2}{*}{ Dpub.99.G } & - & - & $0,317 * * *$ & $0,039 * *$ \\
\hline & & & $(0,024)$ & $(0,015)$ \\
\hline \multirow[t]{2}{*}{ Dpub.01.G } & - & - & $0,295 * * *$ & $0,051 * * *$ \\
\hline & & & $(0,024)$ & $(0,015)$ \\
\hline \multirow[t]{2}{*}{ Dpub.03.G } & - & - & $0,282 * * *$ & $0,033 * *$ \\
\hline & & & $(0,026)$ & $(0,016)$ \\
\hline \multirow[t]{2}{*}{ Dpub.05.G } & - & - & $0,056 * *$ & $-0,045 * * *$ \\
\hline & & & $(0,026)$ & $(0,015)$ \\
\hline \multirow[t]{2}{*}{ Constante } & $2,809 * * *$ & $2,811 * * *$ & $2,819 * * *$ & $3,725 * * *$ \\
\hline & $(0,016)$ & $(0,016)$ & $(0,016)$ & $(0,017)$ \\
\hline Obs & 21.031 & 21.031 & 21.031 & 12.365 \\
\hline Grupos & 2.837 & 2.837 & 2.837 & 2.473 \\
\hline R2 within & 0,549 & 0,562 & 0,559 & 0,237 \\
\hline R2between & 0,141 & 0,109 & 0,097 & 0,363 \\
\hline R2 overall & 0,077 & 0,088 & 0,094 & 0,032 \\
\hline
\end{tabular}

\subsubsection{Professores com o $3^{\circ}$ grau completo}

Um dos objetivos do FUNDEF foi valorizar o papel do professor no ensino fundamental. O compromisso de dedicar $60 \%$ dos recursos advindos do Fundo com os salários destes profissionais visou incentivar a carreira e, conseqüentemente, elevar a concorrência e a qualidade dos professores. 
A Tabela 39 traz os resultados do estimador de diferenças em diferenças mais simples obtido por (4.2) para a variável dependente "proporção de professores de $1^{\mathrm{a}}$ a $4^{\mathrm{a}}$ série com o $3^{\mathrm{o}}$ grau". Os resultados indicam ter havido um "efeito-FUNDEF"de melhora relativa deste indicador nas escolas municipais nos anos de 2003 e 2005. A Tabela 40 traz os resultados da mesma estimação para a variável dependente "proporção de professores de $5^{\mathrm{a}}$ a $8^{\mathrm{a}}$ série com o $3^{\mathrm{o}}$ grau". Neste caso, a maioria dos parâmetros estimados se mostraram não significativos, à exceção daquele relativo ao ano de 2005 , que apresentou sinal negativo e significativo a $1 \%$. Portanto, por estes primeiros resultados, o impacto positivo do FUNDEF sobre a qualidade dos professores do ensino fundamental na rede pública só ocorreu a partir de 2003, e apenas no caso dos professores de $1^{\mathrm{a}}$ a $4^{\mathrm{a}}$ série.

Tabela 39- Estimador DD da equação (4.2) para "professores de $1^{\mathrm{a}}$ a $4^{\mathrm{a}} \operatorname{com}$ o $3^{\circ}$ grau"

\begin{tabular}{|c|c|c|c|}
\hline & Pública & Privada & Diferença \\
\hline 1996 & 0,074 & 0,131 & $-0,057$ \\
\hline 1999 & 0,126 & 0,174 & $-0,048$ \\
\hline Diferença & 0,052 & 0,043 & 0,009 \\
\hline Desvio Padrão & & & $(0,008)$ \\
\hline & Pública & Privada & Diferença \\
\hline 1996 & 0,074 & 0,131 & $-0,057$ \\
\hline 2001 & 0,153 & 0,198 & $-0,045$ \\
\hline Diferença & 0,079 & 0,067 & 0,012 \\
\hline Desvio Padrão & & & $(0,008)$ \\
\hline & Pública & Privada & Diferença \\
\hline 1996 & 0,074 & 0,131 & $-0,057$ \\
\hline 2003 & 0,228 & 0,235 & $-0,007$ \\
\hline $\begin{array}{l}\text { Diferença } \\
\text { Desvio Padrão }\end{array}$ & 0,154 & 0,104 & $\begin{array}{r}0,05 * * * \\
(0,008)\end{array}$ \\
\hline & Pública & Privada & Diferença \\
\hline 1996 & 0,074 & 0,131 & $-0,057$ \\
\hline 2005 & 0,274 & 0,281 & $-0,007$ \\
\hline $\begin{array}{l}\text { Diferença } \\
\text { Desvio Padrão }\end{array}$ & 0,2 & 0,15 & $\begin{array}{r}0,05 * * * \\
(0,009)\end{array}$ \\
\hline
\end{tabular}


Tabela 40- Estimador DD da equação (4.2) para "professores de $5^{\mathrm{a}}$ a $8^{\mathrm{a}} \operatorname{com}$ o $3^{\circ}$ grau"

\begin{tabular}{|c|c|c|c|}
\hline & Pública & Privada & Diferença \\
\hline 1996 & 0,034 & 0,286 & $-0,252$ \\
\hline 1999 & 0,053 & 0,301 & $-0,248$ \\
\hline \multirow{3}{*}{$\begin{array}{l}\text { Diferença } \\
\text { Desvio Padrão }\end{array}$} & 0,019 & 0,015 & 0,004 \\
\hline & & & $(0,009)$ \\
\hline & Pública & Privada & Diferença \\
\hline 1996 & 0,034 & 0,286 & $-0,252$ \\
\hline 2001 & 0,065 & 0,312 & $-0,247$ \\
\hline \multirow{3}{*}{$\begin{array}{l}\text { Diferença } \\
\text { Desvio Padrão }\end{array}$} & 0,031 & 0,026 & 0,005 \\
\hline & & & $(0,009)$ \\
\hline & Pública & Privada & Diferença \\
\hline 1996 & 0,034 & 0,286 & $-0,252$ \\
\hline 2003 & 0,088 & 0,337 & $-0,249$ \\
\hline \multirow{3}{*}{$\begin{array}{l}\text { Diferença } \\
\text { Desvio Padrão }\end{array}$} & 0,054 & 0,051 & 0,003 \\
\hline & & & $(0,009)$ \\
\hline & Pública & Privada & Diferença \\
\hline 1996 & 0,034 & 0,286 & $-0,252$ \\
\hline 2005 & 0,087 & 0,364 & $-0,277$ \\
\hline Diferença & 0,053 & 0,078 & $-0,025 * * *$ \\
\hline Desvio Padrão & & & $(0,009)$ \\
\hline
\end{tabular}

Quanto as estimações por Efeitos Fixos, a Tabela 41 traz os resultados para o caso da variável dependente ser a proporção de professores de $1^{\text {a }}$ a $4^{\text {a }}$ série com o $3^{\circ}$ grau completo. Os modelos 1, 2, e 3 apontam que houve uma diminuição na proporção desses professores após o FUNDEF, indo ao encontro dos resultados da Tabela 40. Já o modelo 4, que toma como grupo de controle apenas as escolas municipais cujos municípios receberam transferências líquidas do Fundo menores ou iguais a zero, parece ter havido um aumento na proporção deste tipo de professor nas escolas que foram beneficiadas pelo plano no primeiro ano seguinte a sua entrada em vigor (1999). 
Tabela 41- Estimações por efeitos fixos de município para "professores de $1^{\mathrm{a}}$ a $4^{\mathrm{a}} \operatorname{com}$ o $3^{\circ}$ grau"

\begin{tabular}{|c|c|c|c|c|}
\hline Variáveis & Modelo 1 & Modelo 2 & Modelo 3 & Modelo 4 \\
\hline \multirow[t]{2}{*}{ D_1999 } & $0,037 * * *$ & $0,037 * * *$ & $0,037 * * *$ & $0,031 * * *$ \\
\hline & $(0,006)$ & $(0,006)$ & $(0,006)$ & $(0,005)$ \\
\hline \multirow[t]{2}{*}{ D_2001 } & $0,060 * * *$ & $0,060 * * *$ & $0,060 * * *$ & $0,061 * * *$ \\
\hline & $(0,006)$ & $(0,006)$ & $(0,006)$ & $(0,005)$ \\
\hline \multirow[t]{2}{*}{ D_2003 } & $0,097 * * *$ & $0,097 * * *$ & $0,098 * * *$ & $0,158 * * *$ \\
\hline & $(0,006)$ & $(0,006)$ & $(0,006)$ & $(0,006)$ \\
\hline \multirow[t]{2}{*}{ D_2005 } & $0,145 * * *$ & $0,145 * * *$ & $0,145 * * *$ & $0,170 * * *$ \\
\hline & $(0,006)$ & $(0,006)$ & $(0,006)$ & $(0,005)$ \\
\hline \multirow[t]{2}{*}{ Publ } & $-0,034 * * *$ & $-0,034 * * *$ & $-0,032 * * *$ & - \\
\hline & $(0,005)$ & $(0,005)$ & $(0,005)$ & \\
\hline \multirow[t]{2}{*}{ dpub1999 } & 0,007 & 0,006 & 0,010 & - \\
\hline & $(0,007)$ & $(0,007)$ & $(0,008)$ & \\
\hline \multirow[t]{2}{*}{ dpub2001 } & 0,011 & 0,009 & 0,013 & - \\
\hline & $(0,007)$ & $(0,007)$ & $(0,008)$ & \\
\hline \multirow[t]{2}{*}{ dpub2003 } & $0,049 * * *$ & $0,049 * * *$ & $0,079 * * *$ & - \\
\hline & $(0,007)$ & $(0,007)$ & $(0,009)$ & \\
\hline \multirow[t]{2}{*}{ dpub2005 } & $0,047 * * *$ & $0,047 * * *$ & $0,041 * * *$ & - \\
\hline & $(0,007)$ & $(0,007)$ & $(0,008)$ & \\
\hline \multirow[t]{2}{*}{ Dpub.99.V } & - & $-0,007 * * *$ & & - \\
\hline & & $(0,002)$ & - & \\
\hline \multirow[t]{2}{*}{ Dpub.01.V } & - & $-0,005 * * *$ & & - \\
\hline & & $(0,002)$ & - & \\
\hline \multirow[t]{2}{*}{ Dpub.03.V } & - & $-0,007 * * *$ & & - \\
\hline & & $(0,002)$ & - & \\
\hline \multirow[t]{2}{*}{ Dpub.05.V } & - & 0,000 & & - \\
\hline & & $(0,000)$ & - & \\
\hline \multirow[t]{2}{*}{ Dpub.99.G } & - & - & $-0,006$ & $0,014 * *$ \\
\hline & & & $(0,007)$ & $(0,006)$ \\
\hline \multirow[t]{2}{*}{ Dpub.01.G } & - & - & $-0,005$ & 0,009 \\
\hline & & & $(0,007)$ & $(0,006)$ \\
\hline \multirow[t]{2}{*}{ Dpub.03.G } & - & - & $-0,046^{* * *}$ & $-0,026 * * *$ \\
\hline & & & $(0,007)$ & $(0,006)$ \\
\hline \multirow[t]{2}{*}{ Dpub.05.G } & - & - & 0,011 & $0,028 * * *$ \\
\hline & & & $(0,006)$ & $(0,006)$ \\
\hline \multirow[t]{2}{*}{ Constante } & $0,122 * * *$ & $0,122 * * *$ & $0,121 * * *$ & $0,086 * * *$ \\
\hline & $(0,004)$ & $(0,004)$ & $(0,004)$ & $(0,003)$ \\
\hline Obs & 20.986 & 20.986 & 20.986 & 13.867 \\
\hline Grupos & 2.809 & 2.809 & 2.809 & 2.801 \\
\hline R2 within & 0,157 & 0,159 & 0,159 & 0,225 \\
\hline R2between & 0,063 & 0,072 & 0,114 & 0,065 \\
\hline R2 overall & 0,093 & 0,096 & 0,098 & 0,100 \\
\hline
\end{tabular}

A Tabela 42 traz os resultados das estimações dos modelos de efeitos fixos para o caso da variável dependente ser a proporção de professores de $5^{\mathrm{a}}$ a $8^{\mathrm{a}}$ série com o $3^{\mathrm{o}}$ grau completo. Pode-se notar que, entre os modelos 1, 2 e 3, há grande semelhança nos parâmetros obtidos das variáveis que esses modelos possuem em comum. Isto faz com que volte mais atenção aos resultados dos modelos mais completos (2 e 3). Segundo as estimações dos modelos 2 e 3, o FUNDEF provocou um aumento na qualificação dos professores de $5^{\mathrm{a}}$ a $8^{\mathrm{a}}$ série nos anos de 
1999 e 2001 segundo o modelo 2, e em todos os anos segundo o modelo 3 . O modelo 4, que compara os indicadores apenas entre as escolas municipais que ganharam ou perderam recursos, o efeito-FUNDEF é positivo em todos os anos, mas significativo a $1 \%$ apenas nos anos 2003 e 2005.

Tabela 42-Estimações por efeitos fixos de município para "professores de $5^{\text {a a }} 8^{\mathrm{a}}$ com o $3^{\circ}$ grau"

\begin{tabular}{|c|c|c|c|c|}
\hline Variáveis & Modelo 1 & Modelo 2 & Modelo 3 & Modelo 4 \\
\hline D_1999 & $\begin{array}{r}0,018 * * * \\
(0,005)\end{array}$ & $\begin{array}{r}0,018 * * * \\
(0,005)\end{array}$ & $\begin{array}{r}0,018 * * * \\
(0,005)\end{array}$ & $\begin{array}{r}0,017 * * * \\
(0,002)\end{array}$ \\
\hline D_2001 & $\begin{array}{r}0,033 * * * \\
(0,005)\end{array}$ & $\begin{array}{r}0,033 * * * \\
(0,005)\end{array}$ & $\begin{array}{r}0,033^{* * *} \\
(0,005)\end{array}$ & $\begin{array}{r}0,029^{* * *} \\
(0,002)\end{array}$ \\
\hline D_2003 & $\begin{array}{r}0,060 * * * \\
(0,005)\end{array}$ & $\begin{array}{r}0,060 * * * \\
(0,005)\end{array}$ & $\begin{array}{r}0,060 * * * \\
(0,005)\end{array}$ & $\begin{array}{r}0,054 * * * \\
(0,003)\end{array}$ \\
\hline D_2005 & $\begin{array}{r}0,089 * * * \\
(0,005)\end{array}$ & $\begin{array}{r}0,089^{* * *} \\
(0,005)\end{array}$ & $\begin{array}{r}0,089^{* * *} \\
(0,005)\end{array}$ & $\begin{array}{r}0,046^{* * * *} \\
(0,002)\end{array}$ \\
\hline Publ & $\begin{array}{r}-0,219 * * * \\
(0,005)\end{array}$ & $\begin{array}{r}-0,219 * * * \\
(0,005)\end{array}$ & $\begin{array}{r}-0,220 * * * \\
(0,005)\end{array}$ & - \\
\hline dpub1999 & $\begin{array}{r}-0,004 \\
(0,006)\end{array}$ & $\begin{array}{r}-0,002 \\
(0,006)\end{array}$ & $\begin{array}{r}-0,017 * * \\
(0,007)\end{array}$ & - \\
\hline dpub2001 & $\begin{array}{r}-0,008 \\
(0,006)\end{array}$ & $\begin{array}{l}-0,006 \\
(0,006)\end{array}$ & $\begin{array}{r}-0,021 * * * \\
(0,007)\end{array}$ & - \\
\hline dpub2003 & $\begin{array}{r}-0,011^{*} \\
(0,006)\end{array}$ & $\begin{array}{r}-0,012^{* *} \\
(0,006)\end{array}$ & $\begin{array}{r}-0,028^{* * *} \\
(0,007)\end{array}$ & - \\
\hline dpub2005 & $\begin{array}{r}-0,042 * * * \\
(0,006)\end{array}$ & $\begin{array}{r}-0,042 * * * \\
(0,006)\end{array}$ & $\begin{array}{r}-0,053^{* * *} \\
(0,007)\end{array}$ & - \\
\hline Dpub.99.V & - & $\begin{array}{r}0,009 * * * \\
(0,002)\end{array}$ & 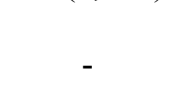 & - \\
\hline Dpub.01.V & - & $\begin{array}{r}0,006^{* * *} \\
(0,002)\end{array}$ & - & - \\
\hline Dpub.03.V & - & $\begin{array}{r}0,003 \\
(0,002)\end{array}$ & - & - \\
\hline Dpub.05.V & - & $\begin{array}{r}0,000 \\
(0,000)\end{array}$ & - & - \\
\hline Dpub.99.G & - & - & $\begin{array}{r}0,025^{* * *} * \\
(0,005)\end{array}$ & $\begin{array}{r}0,004 \\
(0,003)\end{array}$ \\
\hline Dpub.01.G & - & - & $\begin{array}{r}0,026 * * * \\
(0,005)\end{array}$ & $\begin{array}{r}0,004 \\
(0,003)\end{array}$ \\
\hline Dpub.03.G & - & - & $\begin{array}{r}0,025^{* * *} * \\
(0,006)\end{array}$ & $\begin{array}{r}0,001 \\
(0,003)\end{array}$ \\
\hline Dpub.05.G & - & - & $\begin{array}{r}0,020 * * * \\
(0,005)\end{array}$ & $\begin{array}{r}0,013 * * * \\
(0,003)\end{array}$ \\
\hline Constante & $\begin{array}{c}0,265 * * * \\
(0,004)\end{array}$ & $\begin{array}{c}0,265 * * * \\
(0,004)\end{array}$ & $\begin{array}{r}0,266^{* * *} * \\
(0,004)\end{array}$ & $\begin{array}{r}0,034 * * * \\
(0,001)\end{array}$ \\
\hline Obs & 20.986 & 20.986 & 20.986 & 13.867 \\
\hline Grupos & 2.809 & 2.809 & 2.809 & 2.801 \\
\hline R2 within & 0,401 & 0,402 & 0,403 & 0,104 \\
\hline R2between & 0,336 & 0,329 & 0,321 & 0,006 \\
\hline R2 overall & 0,349 & 0,347 & 0,346 & 0,028 \\
\hline
\end{tabular}

Desvios padrões em parênteses. Grau de significância: *10\%, ** 5\%, *** $1 \%$

Portanto, parece que o efeito do Fundo sobre a qualidade dos professores no ensino fundamental das escolas públicas foi o de ter aumentado a qualificação daqueles dedicados às 
séries de $5^{\mathrm{a}}$ a $8^{\mathrm{a}}$, relativamente as escolas particulares e as escolas publicas que perderam recursos para o Fundo. Por outro lado, parece ter havido uma diminuição na qualificação dos professores que se dedicam ao ensino de $1^{\mathrm{a}}$ a $4^{\mathrm{a}}$ série, talvez pelo aumento da demanda neste nível de ensino e uma escassez de professores qualificados no mercado.

\subsubsection{Fluxo e rendimento escolar}

\subsubsection{Taxa de reprovação}

A Tabela 43 traz os resultados dos estimadores de diferenças em diferenças obtidos a partir da equação (4.2) para a taxa de reprovação no ensino fundamental, para os ciclos de $1^{\mathrm{a}}$ a $4^{\mathrm{a}}$, de $5^{\mathrm{a}}$ a $8^{\mathrm{a}}$ e também para cada série separadamente. A primeira linha da Tabela 43 mostra que, no que diz respeito ao ensino fundamental como um todo, houve um aumento da reprovação nas escolas municipais relativamente às escolas privadas nos anos de 2003 e 2005, tendo como base a taxa de reprovação em 1997. O mesmo resultado é obtido quando se faz a análise para o primeiro ciclo do ensino fundamental (de $1^{\mathrm{a}}$ a $4^{\mathrm{a}}$ série) separadamente: a taxa de repetência aumenta nos anos 2003 e 2005 nas escolas municipais. Para os anos 1999 e 2001, os parâmetros estimados apresentaram sinal negativo mas não são estatisticamente significantes. Quanto ao segundo ciclo do ensino fundamental (de $5^{\mathrm{a}}$ a $8^{\mathrm{a}}$ série), os estimadores de diferenças em diferenças do "efeito- FUNDEF" apresentaram sinal positivo e significância a $1 \%$ em todos os anos pós-FUNDEF.

Quando se analisa os resultados para cada série separadamente, observa-se que na $1^{\text {a }}$ série houve um aumento relativo na taxa de reprovação em 2005 , na $2^{\mathrm{a}}$ série este aumento começou em 2003, na $3^{\text {a }}$ série em 2001 e na quarta série a repetência apresenta um aumento logo a partir de 1999. No que diz respeito a reprovação no segundo ciclo do ensino fundamental, que vai da $5^{\mathrm{a}}$ a $8^{\mathrm{a}}$ série, o aumento da reprovação após a introdução do FUNDEF se dá em todos os anos analisados. 
Tabela 43-Estimador DD da equação (4.2) para "taxa de reprovação"

\begin{tabular}{|c|c|c|c|c|}
\hline Taxa de reprovação & Dpub.1999 & Dpub.2001 & Dpub.2003 & Dpub.2005 \\
\hline No ensino fundamental & $\begin{array}{c}-0,058 \\
(0,309)\end{array}$ & $\begin{array}{l}-0,028 \\
(0,307)\end{array}$ & $\begin{array}{c}0,801 * * * \\
(0,311)\end{array}$ & $\begin{array}{c}1,393 * * * \\
(0,323)\end{array}$ \\
\hline De $1^{\mathrm{a}}$ a $4^{\mathrm{a}}$ série & $\begin{array}{l}-0,202 \\
(0,318)\end{array}$ & $\begin{array}{c}-0,251 \\
(0,320)\end{array}$ & $\begin{array}{l}\mathbf{0 , 5 8 2} * \\
(\mathbf{0 , 3 2 3})\end{array}$ & $\begin{array}{c}1,140 * * * \\
(0,337)\end{array}$ \\
\hline De $5^{\mathrm{a}}$ a $8^{\mathrm{a}}$ série & $\begin{array}{l}0,677 * \\
(0,349)\end{array}$ & $\begin{array}{c}1,282 * * * \\
(0,354)\end{array}$ & $\begin{array}{c}3,736 * * * \\
(0,325)\end{array}$ & $\begin{array}{c}4,651 * * * \\
(0,356)\end{array}$ \\
\hline $1^{\mathrm{a}}$ série & $\begin{array}{l}-0,185 \\
(0,424)\end{array}$ & $\begin{array}{l}-0,148 \\
(0,424)\end{array}$ & $\begin{array}{c}0,258 \\
(0,418)\end{array}$ & $\begin{array}{c}1,233 * * * \\
(0,437)\end{array}$ \\
\hline $2^{a}$ série & $\begin{array}{c}-0,571 \\
(0,354)\end{array}$ & $\begin{array}{c}0,270 \\
(0,336)\end{array}$ & $\begin{array}{c}1,477 * * * \\
(0,337)\end{array}$ & $\begin{array}{c}1,712 * * * \\
(0,355)\end{array}$ \\
\hline $3^{\mathrm{a}}$ série & $\begin{array}{c}0,013 \\
(0,309)\end{array}$ & $\begin{array}{l}0,763^{* *} \\
(0,302)\end{array}$ & $\begin{array}{c}1,898 * * * \\
(0,301)\end{array}$ & $\begin{array}{c}2,706 * * * \\
(0,318)\end{array}$ \\
\hline $4^{\mathrm{a}}$ série & $\begin{array}{c}0,913 * * * \\
(0,304)\end{array}$ & $\begin{array}{c}1,726 * * * \\
(0,294)\end{array}$ & $\begin{array}{c}2,646 * * * \\
(0,294)\end{array}$ & $\begin{array}{c}3,051 * * * \\
(0,315)\end{array}$ \\
\hline $5^{\mathrm{a}}$ série & $\begin{array}{c}0,709 \\
(0,446)\end{array}$ & $\begin{array}{c}1,896 * * * \\
(0,456)\end{array}$ & $\begin{array}{c}5,357 * * * \\
(0,440)\end{array}$ & $\begin{array}{c}7,080 * * * \\
(0,465)\end{array}$ \\
\hline $6^{\mathrm{a}}$ série & $\begin{array}{c}1,385 * * * \\
(0,431)\end{array}$ & $\begin{array}{c}1,781 * * * \\
(0,419)\end{array}$ & $\begin{array}{c}3,856 * * * \\
(0,404)\end{array}$ & $\begin{array}{c}5,140 * * * \\
(0,433)\end{array}$ \\
\hline $7^{\mathrm{a}}$ série & $\begin{array}{c}1,344 * * * \\
(0,393)\end{array}$ & $\begin{array}{c}1,576 * * * \\
(0,410)\end{array}$ & $\begin{array}{c}3,309 * * * \\
(0,374)\end{array}$ & $\begin{array}{c}4,533 * * * \\
(0,384)\end{array}$ \\
\hline $8^{\mathrm{a}}$ série & $\begin{array}{l}\mathbf{0 , 5 9 5 * *} \\
(\mathbf{0 , 3 1 1 )}\end{array}$ & $\begin{array}{c}0,956 * * * \\
(0,325)\end{array}$ & $\begin{array}{c}1,748 * * * \\
(0,288)\end{array}$ & $\begin{array}{c}2,282 * * * \\
(0,311)\end{array}$ \\
\hline
\end{tabular}

A Tabela 44 traz os resultados das estimações por efeitos fixos tendo como variável dependente a taxa de reprovação do ensino fundamental como um todo. Os modelos 1 e 2 apontam que houve um aumento da taxa de reprovação nas escolas municipais, decorrente do FUNDEF, a partir de 2003. O modelo 3, que tem como grupo de tratamento apenas as escolas municipais cujos municípios receberam transferências líquidas positivas do Fundo, mostra que o aumento da reprovação se dá logo no primeiro ano (1999) após a entrada em vigor da nova política. Já o modelo 4, em que se comparam os resultados apenas entre escolas municipais que ganharam ou perderam recursos com o Fundo, não aponta qualquer resultado significativo do efeito-FUNDEF sobre o indicador educacional de interesse. 
Tabela 44-Estimações por efeitos fixos de município para "taxa de reprovação"

\begin{tabular}{|c|c|c|c|c|}
\hline Variáveis & Modelo 1 & Modelo 2 & Modelo 3 & Modelo 4 \\
\hline \multirow[t]{2}{*}{ D_1999 } & $-1,342 * * *$ & $-1,342 * * *$ & $-1,344 * * *$ & $-1,293 * * *$ \\
\hline & $(0,211)$ & $(0,211)$ & $(0,210)$ & $(0,188)$ \\
\hline \multirow[t]{2}{*}{ D_2001 } & $-1,416^{* * *}$ & $-1,416^{* * *}$ & $-1,418 * * *$ & $-1,445 * * *$ \\
\hline & $(0,210)$ & $(0,210)$ & $(0,210)$ & $(0,188)$ \\
\hline \multirow[t]{2}{*}{ D_2003 } & $-1,536 * * *$ & $-1,535 * * *$ & $-1,538 * * *$ & $-0,683 * * *$ \\
\hline & $(0,209)$ & $(0,209)$ & $((0,209)$ & $(0,223)$ \\
\hline \multirow[t]{2}{*}{ D_2005 } & $-1,415 * * *$ & $-1,414 * * *$ & $-1,417 * * *$ & $-0,394 * *$ \\
\hline & $(0,207)$ & $(0,207)$ & $(0,207)$ & $(0,199)$ \\
\hline \multirow[t]{2}{*}{ Publ } & $10,161 * * *$ & $10,158 * * *$ & $10,140 * * *$ & - \\
\hline & $(0,188)$ & $(0,188)$ & $(0,188)$ & \\
\hline \multirow[t]{2}{*}{ dpub1999 } & $-0,170$ & $-0,109$ & $-0,515^{*}$ & - \\
\hline & $(0,257)$ & $(0,257)$ & $(0,283)$ & \\
\hline \multirow[t]{2}{*}{ dpub2001 } & $-0,221$ & $-0,193$ & $-0,522 *$ & - \\
\hline & $(0,256)$ & $(0,256)$ & $(0,282)$ & \\
\hline \multirow[t]{2}{*}{ dpub2003 } & $0,629 * *$ & $0,622 * *$ & 0,106 & - \\
\hline & $(0,255)$ & $(0,255)$ & $(0,303)$ & \\
\hline \multirow[t]{2}{*}{ dpub2005 } & $1,150 * * *$ & $1,158 * * *$ & $0,808 * * *$ & - \\
\hline & $(0,257)$ & $(0,258)$ & $(0,292)$ & \\
\hline \multirow[t]{2}{*}{ Dpub.99.V } & - & $0,240 * * *$ & & - \\
\hline & & $(0,074)$ & - & \\
\hline \multirow[t]{2}{*}{ Dpub.01.V } & - & $0,086^{* * *}$ & & - \\
\hline & & $(0,033)$ & - & \\
\hline \multirow[t]{2}{*}{ Dpub.03.V } & - & $0,127 * *$ & & - \\
\hline & & $(0,063)$ & - & \\
\hline \multirow[t]{2}{*}{ Dpub.05.V } & - & $-0,003$ & & - \\
\hline & & $(0,004)$ & - & \\
\hline \multirow[t]{2}{*}{ dpubG99 } & - & - & $0,667 * * *$ & $-0,354$ \\
\hline & & & $(0,227)$ & $(0,234)$ \\
\hline \multirow[t]{2}{*}{ dpubG01 } & - & - & $0,577 * *$ & $-0,115$ \\
\hline & & & $(0,228)$ & $(0,234)$ \\
\hline \multirow[t]{2}{*}{ dpubG03 } & - & - & $0,778 * * *$ & $-0,040$ \\
\hline & & & $(0,243)$ & $(0,250)$ \\
\hline \multirow[t]{2}{*}{ dpubG05 } & - & - & $0,584 * *$ & 0,314 \\
\hline & & & $(0,241)$ & $(0,233)$ \\
\hline \multirow[t]{2}{*}{ Constante } & $4,500 * * *$ & $4,503 * * *$ & $4,515 * * *$ & $14,856 * * *$ \\
\hline & $(0,153)$ & $(0,153)$ & $(0,153)$ & $(0,103)$ \\
\hline Obs & 20.982 & 20.982 & 20.982 & 12.362 \\
\hline Grupos & 2.837 & 2.837 & 2.837 & 2.473 \\
\hline R2 within & 0,425 & 0,425 & 0,426 & 0,018 \\
\hline R2between & 0,175 & 0,181 & 0,189 & 0,041 \\
\hline R2 overall & 0,319 & 0,321 & 0,324 & 0,003 \\
\hline
\end{tabular}

Por que o FUNDEF teria induzido um aumento da reprovação no ensino fundamental das escolas municipais em geral e em especial nas últimas séries do ciclo? O argumento de Andrade et al. (2008) é de que as regras do Fundo teriam criado um incentivo para os professores reprovarem mais os alunos como forma de tentar, com isso, um aumento de seus salários, uma vez que o montante de recursos destinados aos municípios passou a ser proporcional ao número de alunos matriculados em suas redes. Segundo o modelo proposto pelos autores, a manipulação da taxa de reprovação ocorreria principalmente nas séries finais 
do ensino fundamental, dada a menor probabilidade de abandono por parte do aluno que já cumpriu pelo menos a metade do ensino obrigatório.

Por outro lado, viu-se que aumentaram as matrículas no ensino fundamental da rede municipal como decorrência do FUNDEF (Tabelas 25 e 26), o que pode ter levado a queda do nível dos alunos matriculados. Além disso, os resultados da seção que analisou o impacto do FUNDEF sobre a qualificação dos professores apontam que houve uma piora no grau de instrução dos professores de $1^{\mathrm{a}}$ à $4^{\mathrm{a}}$ série nas escolas municipais após a mudança de política, enquanto elevou-se a proporção de professores de $5^{\mathrm{a}}$ a $8^{\mathrm{a}}$ série com diploma de $3^{\mathrm{o}}$ grau em todos os anos. Estes dois efeitos combinados também podem ajudar a explicar o padrão observado nas taxas de reprovação para o ensino fundamental nas escolas municipais.

Pode-se inferir que professores mais capacitados tenderiam a ser mais exigentes com seus alunos, enquanto professores menos capacitados tenderiam a ser mais lenientes. Disto não resulta que os professores mais qualificados necessariamente reprovem mais. Na realidade, um ensino de qualidade faz com que os alunos aprendam mais e, portanto, não reprovem e tendam a permanecer nas escolas. Para tirar uma conclusão a respeito da melhora ou piora da qualidade do ensino decorrentes do FUNDEF é necessário olhar também o que ocorreu com as taxas de aprovação e abandono. Para que se possa afirmar que houve uma melhora na qualidade, dado que a reprovação aumentou (principalmente nas séries finais do ensino fundamental), é preciso que as taxas de aprovação tenham também aumentado e /ou que as taxas de abandono tenham diminuído.

\subsubsection{Taxa de aprovação}

A Tabela 45 traz os estimadores de diferenças em diferenças obtidos a partir da equação (4.2) para a variável dependente "taxa de aprovação" no ensino fundamental como um todo, bem como por ciclo e por série. Os resultados para o ensino fundamental apontam que houve um aumento da aprovação em geral. Quando se olha para as taxas por ciclo, os resultados são de que a aprovação aumentou no ciclo de $1^{\mathrm{a}}$ a $4^{\mathrm{a}}$ série, e diminuiu no ciclo de $5^{\mathrm{a}}$ a $8^{\mathrm{a}}$ série, em todos os anos analisados após a entrada em vigor do FUNDEF. Estes resultados se confirmam quando se vê os resultados das estimações para cada série individualmente. 
Tabela 45- Estimador DD da equação (4.2) para "taxa de aprovação"

\begin{tabular}{|c|c|c|c|c|}
\hline Taxa de aprovação & Dpub.1999 & Dpub.2001 & Dpub.2003 & Dpub.2005 \\
\hline No ensino fundamental & $\begin{array}{c}1,347 * * \\
(0,535)\end{array}$ & $\begin{array}{c}2,489 * * * \\
(0,517)\end{array}$ & $\begin{array}{c}2,695 * * * \\
(0,514)\end{array}$ & $\begin{array}{c}2,123 * * * \\
(0,517)\end{array}$ \\
\hline De $1^{\mathrm{a}}$ a $4^{\mathrm{a}}$ série & $\begin{array}{c}2,285 * * * \\
(0,537)\end{array}$ & $\begin{array}{c}3,611 * * * \\
(0,517)\end{array}$ & $\begin{array}{c}3,975 * * * \\
(0,518)\end{array}$ & $\begin{array}{c}3,461 * * * \\
(0,521)\end{array}$ \\
\hline De $5^{\mathrm{a}}$ a $8^{\mathrm{a}}$ série & $\begin{array}{c}-1,290 * * \\
(0,578)\end{array}$ & $\begin{array}{c}-1,399 * * * \\
(0,587)\end{array}$ & $\begin{array}{c}-3,154 * * * \\
(0,556)\end{array}$ & $\begin{array}{c}-4,252 * * * \\
(0,580)\end{array}$ \\
\hline $1^{\mathrm{a}}$ série & $\begin{array}{c}2,013 * * * \\
(0,641)\end{array}$ & $\begin{array}{c}3,826 * * * \\
(0,618)\end{array}$ & $\begin{array}{c}4,280 * * * \\
(0,616)\end{array}$ & $\begin{array}{c}3,601 * * * \\
(0,620)\end{array}$ \\
\hline $2^{\mathrm{a}}$ série & $\begin{array}{c}2,213 * * * \\
(0,518)\end{array}$ & $\begin{array}{c}2,308 * * * \\
(0,495)\end{array}$ & $\begin{array}{c}2,548 * * * \\
(0,497)\end{array}$ & $\begin{array}{c}2,546 * * * \\
(0,509)\end{array}$ \\
\hline $3^{\mathrm{a}}$ série & $\begin{array}{c}1,531 * * * \\
(0,484)\end{array}$ & $\begin{array}{c}1,974 \\
(0,475)\end{array}$ & $\begin{array}{c}1,953 * * * \\
(0,474)\end{array}$ & $\begin{array}{l}1,040 * * \\
(0,482)\end{array}$ \\
\hline $4^{\mathrm{a}}$ série & $\begin{array}{c}0,567 \\
(0,449)\end{array}$ & $\begin{array}{c}0,900 * * \\
(0,428)\end{array}$ & $\begin{array}{c}0,888 * * * \\
(0,429)\end{array}$ & $\begin{array}{c}0,542 \\
(0,445)\end{array}$ \\
\hline $5^{\mathrm{a}}$ série & $\begin{array}{c}-1,569 * * \\
(0,711)\end{array}$ & $\begin{array}{c}-1,471 * * \\
(0,716)\end{array}$ & $\begin{array}{c}-4,320 * * * \\
(0,701)\end{array}$ & $\begin{array}{c}-6,302 * * * \\
(0,720)\end{array}$ \\
\hline $6^{\mathrm{a}}$ série & $\begin{array}{c}-1,654 * * * \\
(0,640)\end{array}$ & $\begin{array}{c}-1,465 * * \\
(0,634)\end{array}$ & $\begin{array}{c}-2,743 * * * \\
(0,616)\end{array}$ & $\begin{array}{c}-4,503 * * * \\
(0,641)\end{array}$ \\
\hline $7^{\mathrm{a}}$ série & $\begin{array}{c}-2,291 * * * \\
(0,631)\end{array}$ & $\begin{array}{c}-2,824 * * * \\
(0,640)\end{array}$ & $\begin{array}{c}-4,170 * * * \\
(0,610)\end{array}$ & $\begin{array}{c}-5,132 * * * \\
(0,608)\end{array}$ \\
\hline $8^{a}$ série & $\begin{array}{c}-1,220 * * \\
(0,575)\end{array}$ & $\begin{array}{c}-1,859 * * * \\
(0,573)\end{array}$ & $\begin{array}{c}-2,520 * * * \\
(0,538)\end{array}$ & $\begin{array}{c}-3,576 * * * \\
(0,558)\end{array}$ \\
\hline
\end{tabular}

Desvios padrões em parênteses. Grau de significância: *10\%,** 5\%, ***1\%

A Tabela 46 traz as estimações pelos modelos de Efeitos Fixos de município para a variável dependente "taxa de aprovação no ensino fundamental". Novamente, os modelos 1 e 2 apresentam resultados muito semelhantes para as interações de dummy de escola pública e dummies de ano, o que nos faz considerar o modelo 2 mais completo que o modelo 1 para estimar o efeito-Fundef, uma vez que ele inclui também as interações de dummy de escola pública, dummies de ano e o valor líquido por aluno (V) repassado ao município pelo FUNDEF.

De acordo com o modelo 2, o FUNDEF provocou uma redução nas taxas de aprovação das escolas municipais nos municípios que receberam valores líquidos positivos do Fundo. Esta redução se mostrou mais forte, em termos de magnitude do coeficiente estimado e em termos de significância estatística (1\%), no ano de 1999. Já no modelo 3, em que são incluídas como grupo de controle, além das escolas privadas, as escolas municipais cujos municípios não receberam transferências positivas do Fundo, o efeito-Fundef sobre as taxas de aprovação nos municípios beneficiados apresentou sinal negativo e significância de $1 \%$ em todos os anos analisados. 
Tabela 46- Estimações por efeitos fixos de município para "taxa de aprovação"

\begin{tabular}{|c|c|c|c|c|}
\hline Variáveis & Modelo 1 & Modelo 2 & Modelo 3 & Modelo 4 \\
\hline \multirow[t]{2}{*}{ D_1999 } & $2,931 * * *$ & $2,931 * * *$ & $2,933 * * *$ & $4,494 * * *$ \\
\hline & $(0,309)$ & $(0,309)$ & $(0,309)$ & $(0,259)$ \\
\hline \multirow[t]{2}{*}{ D_2001 } & $3,404 * * *$ & $3,404 * * *$ & $3,407 * * *$ & $5,930 * * *$ \\
\hline & $(0,308)$ & $(0,308)$ & $(0,307)$ & $(0,259)$ \\
\hline \multirow[t]{2}{*}{ D_2003 } & $3,702 * * *$ & $3,701 * * *$ & $3,705 * * *$ & $6,064 * * *$ \\
\hline & $(0,306)$ & $(0,306)$ & $(0,306)$ & $(0,308)$ \\
\hline \multirow[t]{2}{*}{ D_2005 } & $3,835 * * *$ & $3,833 * * *$ & $3,837 * * *$ & $6,693 * * *$ \\
\hline & $(0,304)$ & $(0,304)$ & $(0,304)$ & $(0,275)$ \\
\hline \multirow[t]{2}{*}{ Publ } & $-18,968 * * *$ & $-18,969 * * *$ & $-18,934 * * *$ & - \\
\hline & $(0,277)$ & $(0,276)$ & $(0,277)$ & \\
\hline \multirow[t]{2}{*}{ dpub1999 } & $1,581 * * *$ & $1,446 * * *$ & $2,418 * * *$ & - \\
\hline & $(0,377)$ & $(0,378)$ & $(0,415)$ & \\
\hline \multirow[t]{2}{*}{ dpub2001 } & $2,870 * * *$ & $2,838 * * *$ & $3,368 * * *$ & - \\
\hline & $(0,376)$ & $(0,376)$ & $(0,414)$ & \\
\hline \multirow[t]{2}{*}{ dpub2003 } & $3,024 * * *$ & $3,034 * * *$ & $3,568 * * *$ & - \\
\hline & $(0,375)$ & $(0,374)$ & $(0,445)$ & \\
\hline \multirow[t]{2}{*}{ dpub2005 } & $2,636 * * *$ & $2,666 * * *$ & $3,145 * * *$ & - \\
\hline & $(0,378)$ & $(0,378)$ & $(0,429)$ & \\
\hline \multirow[t]{2}{*}{ dpubV99 } & - & $-0,527 * * *$ & & - \\
\hline & & $(0,109)$ & - & \\
\hline \multirow[t]{2}{*}{ dpubV01 } & - & $-0,098 * *$ & & - \\
\hline & & $(0,049)$ & - & \\
\hline \multirow[t]{2}{*}{ dpubV03 } & - & $-0,172 *$ & & - \\
\hline & & $(0,092)$ & - & \\
\hline \multirow[t]{2}{*}{ dpubV05 } & - & $-0,005$ & & - \\
\hline & & $(0,006)$ & - & \\
\hline \multirow[t]{2}{*}{ dpubG99 } & - & - & $-1,617 * * *$ & 0,171 \\
\hline & & & $(0,334)$ & $(0,323)$ \\
\hline \multirow[t]{2}{*}{ dpubG01 } & - & - & $-0,954 * * *$ & $0,632 * *$ \\
\hline & & & $(0,334)$ & $(0,323)$ \\
\hline \multirow[t]{2}{*}{ dpubG03 } & - & - & $-0,810^{* *}$ & $0,880 * *$ \\
\hline & & & $(0,357)$ & $(0,345)$ \\
\hline \multirow[t]{2}{*}{ dpubG05 } & - & - & $-0,868 * *$ & $-0,226$ \\
\hline & & & $(0,354)$ & $(0,322)$ \\
\hline \multirow[t]{2}{*}{ Constante } & $92,501 * * *$ & $95,500 * * *$ & $92,476 * * *$ & $73,148 * * *$ \\
\hline & $(0,225)$ & $(0,225)$ & $(0,225)$ & $(0,141)$ \\
\hline Obs & 20.982 & 20.982 & 20.982 & 12.362 \\
\hline Grupos & 2.837 & 2.837 & 2.837 & 2.473 \\
\hline R2 within & 0,495 & 0,496 & 0,496 & 0,139 \\
\hline R2between & 0,126 & 0,131 & 0,140 & 0,120 \\
\hline R2 overall & 0,323 & 0,326 & 0,331 & 0,026 \\
\hline
\end{tabular}

Por fim, segundo o modelo 4, que compara a aprovação apenas entre as escolas municipais cujos municípios perderam ou ganharam recursos do Fundo, o efeito-FUNDEF se mostrou positivo e significativo a 5\% nos anos de 2001 e 2003, positivo mas não significativo em 1999 e negativo mas não significativo em 2005. Vale lembrar que nas estimações pelo modelo 4 para as taxas de reprovação nenhum dos coeficientes se mostraram significativos, embora apresentassem o sinal negativo à exceção do parâmetros estimado para o ano de 2005. 


\subsubsection{3}

Taxa de abandono

Na tabela 47 pode-se observar que, segundo o estimador de diferenças em diferenças mais simples, representado pela equação (4.2), o FUNDEF teve o efeito de reduzir as taxas de abandono no ensino fundamental como um todo, bem como as do primeiro ciclo (de $1^{\mathrm{a}}$ a $4^{\mathrm{a}}$ série) deste nível de ensino. As estimações para o $2^{\circ}$ ciclo do ensino fundamental, que vai de $5^{\mathrm{a}}$ a $8^{\mathrm{a}}$ série, não se mostraram estatisticamente significantes. Esses resultados podem ser melhor compreendidos quando se analisa o efeito-Fundef sobre as taxas de abandono em cada série separadamente. Enquanto todos os estimadores para as séries de $1^{\mathrm{a}}$ a $4^{\mathrm{a}}$ apresentaram sinal negativo e significância a $1 \%$, os estimadores obtidos para as séries de $5^{\mathrm{a}}$ a $8^{\mathrm{a}}$ alteraram muito de sinal e significância. Porém, para a $7^{\mathrm{a}}$ e $8^{\mathrm{a}}$ série os estimadores apresentaram sinais positivos e significantes entre $1 \%$ e $10 \%$, o que contradiz a hipótese de Andrade et a (Op cit.). de que a taxa de abandono seria menor nas últimas séries antes de se completar o ensino fundamental.

Tabela 47- Estimador DD da equação (4.2) para "taxa de abandono"

\begin{tabular}{|c|c|c|c|c|}
\hline Taxa de abandono & Dpub.1999 & Dpub.2001 & Dpub.2003 & Dpub.2005 \\
\hline No ensino fundamental & $\begin{array}{c}-1,288 * * * \\
(0,354)\end{array}$ & $\begin{array}{c}-2,460 * * * \\
(0,337)\end{array}$ & $\begin{array}{c}-3,491 * * * \\
(0,330)\end{array}$ & $\begin{array}{c}-3,517 * * * \\
(0,318)\end{array}$ \\
\hline De $1^{\mathrm{a}}$ a $4^{\mathrm{a}}$ série & $\begin{array}{c}-2,083 * * * \\
(0,351)\end{array}$ & $\begin{array}{c}-3,359 * * * \\
(0,326)\end{array}$ & $\begin{array}{c}-4,558 * * * \\
(0,324)\end{array}$ & $\begin{array}{c}-4,602 * * * \\
(0,309)\end{array}$ \\
\hline De $5^{\mathrm{a}}$ a $8^{\mathrm{a}}$ série & $\begin{array}{c}0,612 \\
(0,436)\end{array}$ & $\begin{array}{c}0,117 \\
(0,432)\end{array}$ & $\begin{array}{l}-0,582 \\
(0,420)\end{array}$ & $\begin{array}{l}-0,398 \\
(0,425)\end{array}$ \\
\hline $1^{\mathrm{a}}$ série & $\begin{array}{c}-1,827 * * * \\
(0,396)\end{array}$ & $\begin{array}{c}-3,678 * * * \\
(0,366)\end{array}$ & $\begin{array}{c}-4,539 * * * \\
(0,364)\end{array}$ & $\begin{array}{c}-4,834 * * * \\
(0,345)\end{array}$ \\
\hline $2^{\mathrm{a}}$ série & $\begin{array}{c}-1,642 * * * \\
(0,320)\end{array}$ & $\begin{array}{c}-2,579 * * * \\
(0,304)\end{array}$ & $\begin{array}{c}-4,026 * * * \\
(0,310)\end{array}$ & $\begin{array}{c}-4,259 * * * \\
(0,307)\end{array}$ \\
\hline $3^{\mathrm{a}}$ série & $\begin{array}{c}-1,545 * * * \\
(0,323)\end{array}$ & $\begin{array}{c}-2,737 * * * \\
(0,314)\end{array}$ & $\begin{array}{c}-3,851 * * * \\
(0,312)\end{array}$ & $\begin{array}{c}-3,747 * * * \\
(0,303)\end{array}$ \\
\hline $4^{\mathrm{a}}$ série & $\begin{array}{c}-1,480 * * * \\
(0,300)\end{array}$ & $\begin{array}{c}-2,626 * * * \\
(0,278)\end{array}$ & $\begin{array}{c}-3,534 * * * \\
(0,279)\end{array}$ & $\begin{array}{c}-3,593 * * * \\
(0,275)\end{array}$ \\
\hline $5^{\mathrm{a}}$ série & $\begin{array}{l}\mathbf{0 , 8 6 0 *} \\
(\mathbf{0 , 5 2 3})\end{array}$ & $\begin{array}{l}-0,425 \\
(0,516)\end{array}$ & $\begin{array}{c}-1,036 * * \\
(0,505)\end{array}$ & $\begin{array}{l}-0,778 \\
(0,509)\end{array}$ \\
\hline $6^{\mathrm{a}}$ série & $\begin{array}{c}0,268 \\
(0,468)\end{array}$ & $\begin{array}{l}-0,315 \\
(0,464)\end{array}$ & $\begin{array}{c}-1,113 * * \\
(0,455)\end{array}$ & $\begin{array}{c}-0,637 \\
(0,465)\end{array}$ \\
\hline $7^{\mathrm{a}}$ série & $\begin{array}{l}0,947^{*} \\
(0,487)\end{array}$ & $\begin{array}{c}1,248 * * * \\
(0,483)\end{array}$ & $\begin{array}{l}0,861 * \\
(0,476)\end{array}$ & $\begin{array}{c}0,598 \\
(0,466)\end{array}$ \\
\hline $8^{\mathrm{a}}$ série & $\begin{array}{c}0,624 \\
(0,454)\end{array}$ & $\begin{array}{c}0,902 * * \\
0,444\end{array}$ & $\begin{array}{l}0,771 * \\
(0,427)\end{array}$ & $\begin{array}{c}1,288 * * * \\
(0,432)\end{array}$ \\
\hline
\end{tabular}

Desvios padrões em parênteses. Grau de significância: *10\%, ** 5\%, ***1\% 
Tabela 48- Estimações por efeitos fixos de município para "taxa de abandono"

\begin{tabular}{|c|c|c|c|c|}
\hline Variáveis & Modelo 1 & Modelo 2 & Modelo 3 & Modelo 4 \\
\hline D_1999 & $\begin{array}{r}-1,589 * * * \\
(0,206)\end{array}$ & $\begin{array}{r}-1,589 * * * \\
(0,206)\end{array}$ & $\begin{array}{r}-1,589 * * * \\
(0,206)\end{array}$ & $\begin{array}{r}-3,201 * * * \\
(0,188)\end{array}$ \\
\hline D_2001 & $\begin{array}{r}-1,988 * * * \\
(0,206)\end{array}$ & $\begin{array}{r}-1,988 * * * \\
(0,205)\end{array}$ & $\begin{array}{r}-1,989 * * * \\
(0,205)\end{array}$ & $\begin{array}{r}-4,485^{* * *} \\
(0,188)\end{array}$ \\
\hline D_2003 & $\begin{array}{r}-2,166^{* * *} \\
(0,205)\end{array}$ & $\begin{array}{r}-2,166^{* * *} \\
(0,204)\end{array}$ & $\begin{array}{r}-2,167 * * * \\
(0,204)\end{array}$ & $\begin{array}{r}-5,382 * * * \\
(0,224)\end{array}$ \\
\hline D_2005 & $\begin{array}{r}-2,420^{* * * *} \\
(0,203)\end{array}$ & $\begin{array}{r}-2,419^{* * *} \\
(0,203)\end{array}$ & $\begin{array}{r}-2,420 * * * \\
(0,203)\end{array}$ & $\begin{array}{r}-6,299 * * * \\
(0,200)\end{array}$ \\
\hline Publ & $\begin{array}{r}8,807^{* * *} \\
(0,185)\end{array}$ & $\begin{array}{r}8,811^{* * *} \\
(0,185)\end{array}$ & $\begin{array}{r}8,793^{* * *} \\
(0,185)\end{array}$ & - \\
\hline dpub1999 & $\begin{array}{r}-1,411 * * * \\
(0,252)\end{array}$ & $\begin{array}{r}-1,337 * * * \\
(0,252)\end{array}$ & $\begin{array}{r}-1,903 * * * \\
(0,277)\end{array}$ & - \\
\hline dpub2001 & $\begin{array}{r}-2,649 * * * \\
(0,251)\end{array}$ & $\begin{array}{r}-2,646^{* * *} \\
(0,251)\end{array}$ & $\begin{array}{r}-2,846^{* * *} \\
(0,277)\end{array}$ & - \\
\hline dpub2003 & $\begin{array}{r}-3,653^{* * * *} \\
(0,250)\end{array}$ & $\begin{array}{r}-3,656^{* * *} \\
(0,250)\end{array}$ & $\begin{array}{r}-3,674 * * * \\
(0,297)\end{array}$ & - \\
\hline dpub2005 & $\begin{array}{r}-3,786 * * * \\
(0,252)\end{array}$ & $\begin{array}{r}-3,824 * * * \\
(0,253)\end{array}$ & $\begin{array}{r}-3,954 * * * \\
(0,287)\end{array}$ & - \\
\hline Dpub.99.V & - & $\begin{array}{r}0,286 * * * \\
(0,073)\end{array}$ & - & - \\
\hline Dpub.01.V & - & $\begin{array}{r}0,013 \\
(0,032)\end{array}$ & - & - \\
\hline Dpub.03.V & - & $\begin{array}{r}0,045 \\
(0,062)\end{array}$ & - & - \\
\hline Dpub.05.V & - & $\begin{array}{c}0,007^{*} \\
(0,004)\end{array}$ & - & - \\
\hline dpubG99 & - & - & $\begin{array}{r}0,950 * * * \\
(0,223)\end{array}$ & $\begin{array}{r}0,184 \\
(0,234)\end{array}$ \\
\hline dpubG01 & - & - & $\begin{array}{c}0,377^{*} \\
(0,277)\end{array}$ & $\begin{array}{r}-0,517 * * \\
(0,235)\end{array}$ \\
\hline dpubG03 & - & - & $\begin{array}{r}0,032 \\
(0,239)\end{array}$ & $\begin{array}{r}-0,840 * * * \\
(0,251)\end{array}$ \\
\hline dpubG05 & - & - & $\begin{array}{r}0,284 \\
(0,236)\end{array}$ & $\begin{array}{r}-0,087 \\
(0,251)\end{array}$ \\
\hline _cons & $\begin{array}{c}2,999 * * * \\
(0,150)\end{array}$ & $\begin{array}{c}2,997 * * * \\
(0,150)\end{array}$ & $\begin{array}{r}3,009 * * * \\
(0,150)\end{array}$ & $\begin{array}{r}11,996 * * * \\
(0,103)\end{array}$ \\
\hline Obs & 20.982 & 20.982 & 20.982 & 12.362 \\
\hline Grupos & 2.837 & 2.837 & 2.837 & 2.473 \\
\hline R2 within & 0,307 & 0,308 & 0,308 & 0,205 \\
\hline R2between & 0,040 & 0,042 & 0,048 & 0,098 \\
\hline R2 overall & 0,188 & 0,190 & 0,193 & 0,062 \\
\hline
\end{tabular}

A Tabela 48, com as estimações dos modelos de efeitos fixos de município, traz maior substrato para se analisar os efeitos do Fundo sobre a taxa de abandono nas escolas. Tanto o modelo 2 quanto o modelo 3 apontam que houve um aumento na taxa de abandono no ano seguinte à entrada em vigor do Fundo, e os parâmetros estimados são estatisticamente significantes a 1\%. Segundo ainda o modelo 2, no ano de 2005 houve um pequeno aumento na taxa de abandono das escolas municipais (significativo a $10 \%$ ), enquanto o modelo 3 aponta que houve um aumento do abandono em decorrência do FUNDEF em 2003 
(significante a 10\%). Já o modelo 4, que compara os indicadores apenas entre escolas municipais, o efeito do FUNDEF foi de reduzir o abandono em 2001 e 2003 (significância a $5 \%$ e $10 \%$, respectivamente).

Em termos de indicadores de fluxo e rendimento, portanto, há diferenças quanto aos efeitos do FUNDEF sobre os resultados das escolas ao se tomar diferentes grupos de controle e tratamento para comparação. Quando se comparam escolas municipais e escolas privadas, o efeito do Fundef nas escolas municipais parece ter sido no sentido de: aumentar a taxa de repetência no ensino fundamental como um todo; diminuir a repetência no ensino de $1^{\mathrm{a}}$ a $4^{\mathrm{a}}$ série e aumentar no ensino de $5^{\mathrm{a}}$ a $8^{\mathrm{a}}$; diminuir a aprovação no ensino fundamental como um todo; diminuir o abandono no ensino de $1^{\mathrm{a}}$ a $4^{\mathrm{a}}$ série e aumentá-lo no ensino fundamental como um todo.

Contudo, quando se comparam apenas as escolas municipais nos municípios que ganharam ou perderam recursos para o Fundo, seu feito não se mostrou significativo no que diz respeito a taxa de reprovação; aumentou a taxa de aprovação nos anos de 2001 e 2003 e diminuiu a taxa de abandono em 2001 e 2003. Pode-se afirmar então, neste último caso, que o FUNDEF elevou a qualidade do ensino nas escolas municipais beneficiadas, ao proporcionar um aumento da taxa de aprovação e uma diminuição na taxa de abandono.

\subsection{Comentários Finais}

Neste capítulo procurou-se captar o efeito que o FUNDEF exerceu sobre uma série de indicadores educacionais do ensino fundamental, a saber: total de matrículas; razão do número de alunos pelo total de professores; total de professores; proporção de escolas com laboratório de ciências, laboratório de informática, quadra de esportes, biblioteca; proporção de professores no ensino fundamental de $1^{\mathrm{a}}$ a $4^{\mathrm{a}}$ série com o $3^{\mathrm{o}}$ grau completo e proporção de professores no ensino fundamental de $5^{\mathrm{a}}$ a $8^{\mathrm{a}}$ série com o $3^{\mathrm{o}}$ grau completo; taxa de reprovação; taxa de aprovação e taxa de abandono.

Para tal foram utilizadas as informações do Censo Escolar e da base de dados do Ministério da Fazenda conhecida como FINBRA para se construir um painel de municípios com informações nos anos 1997, 1999, 2001, 2003 e 2005 sobre as características (na média, por 
município) de suas escolas municipais e privadas e sobre os recursos líquidos repassados pelo FUNDEF aos municípios a partir de 1999. Estimou-se o efeito-Fundef sobre cada indicador educacional de interesse pelo método de diferenças em diferenças simples e também com o ajuste de quatro diferentes modelos de efeitos fixos.

No que diz respeito aos efeitos do Fundo sobre as matrículas e alguns dos insumos escolares no ensino fundamental, as estimações indicam que o FUNDEF: provocou um aumento das matrículas; um aumento da razão alunos por professor; um aumento da proporção de escolas municipais com laboratório de ciências e laboratório de informática (especialmente no ano de 1999, neste último caso); um aumento na proporção de escolas beneficiadas com quadras de esporte; um aumento do número de professores dedicados a este nível de ensino; e um aumento na proporção de professores de $5^{\mathrm{a}}$ a $8^{\mathrm{a}}$ série com o $3^{\mathrm{o}}$ grau.

Alguns efeitos estimados do Fundo apresentaram resultados menos claros, e variaram de acordo com o modelo utilizado, como no caso de: a proporção de escolas com bibliotecas; a proporção de professores de $1^{\text {a }}$ a $4^{\text {a }}$ série com o $3^{\circ}$ grau; o efeitos sobre as taxas de reprovação, aprovação e abandono nas escolas. Nestes casos, se o grupo de tratamento for constituído pelas escolas municipais e o grupo de controle apenas pelas escolas privadas, então os resultados apontam para: uma diminuição na proporção de professores de $1^{\mathrm{a}}$ a $4^{\mathrm{a}}$ série com o $3^{\text {o }}$; um aumento nas taxas de reprovação, uma diminuição nas taxas de aprovação e um aumento das tas de abandono no ensino fundamental.

Porém, quando se toma como grupo de controle apenas as escolas municipais nos municípios não beneficiados pelo Fundo (para os quais as transferências líquidas foram negativas ou iguais a zero) e como tratamento as escolas municipais cujos municípios foram beneficiados pelo Fundo, os resultados apontam que o FUNDEF melhorou a qualidade do ensino nas escolas públicas. Neste caso, observa-se um aumento na proporção de professores de $1^{\mathrm{a}}$ a $4^{\mathrm{a}}$ série com o $3^{\circ}$ grau, no ano imediatamente posterior à entrada em vigor do Fundo (1999); um efeito não significativo sobre as taxas de repetência; um efeito positivo sobre as taxas de aprovação nos anos 2001 e 2003e um efeito negativo sobre as taxas de abandono nos mesmos anos. Acredita-se que estes sejam os resultados mais certeiros, dadas as enormes diferenças observada nos indicadores de rendimento e fluxo escolar entre as escolas municipais e as escolas privadas, o que não faz destas últimas um grupo de controle adequado para se analisar o efeito da nova política sobre as primeiras. 


\section{CONCLUSÕES}

Neste trabalho procurou-se explorar em diversos aspectos as informações contidas nos dois maiores e mais importantes levantamentos sobre o Sistema Educacional de ensino básico brasileiro, que são o SAEB e o Censo Escolar.

No capítulo 2 buscou-se identificar os efeitos sobre o aprendizado de uma série de variáveis até então não analisadas por outros estudos do gênero no caso nacional. Isto foi possível por se ter trabalhado com um painel de escolas a partir das informações de cinco anos de avaliações do SAEB (1997, 1999, 2001, 2003 e 2005) que continham, além dos resultados dos alunos nas provas, informações sobre diversos aspectos socioeconômicos de alunos, professores, diretores e informações sobre as turmas e infra-estrutura nas escolas. Importantes resultados que emergiram das análises se mostraram robustos a mudanças no nível de agregação dos dados (observações de dados de indivíduos e também médias para escola) e aos métodos de estimação (Mínimos Quadrados Agrupados e Efeitos Fixos), além das diferenças quanto à inclusão ou exclusão de variáveis nas equações estimadas.

Os resultados obtidos nas análises realizadas no segundo capítulo, tendo como variável dependente o desempenho dos alunos de $4^{\text {a }}$ série nas avaliações de matemática do SAEB, apontam que, no Brasil, são majoritariamente importantes para o desempenho dos alunos as variáveis relacionadas às suas características socioeconômicas. Este resultado não é novo na literatura internacional sobre o tema, de que as características dos alunos e suas famílias exercem grande influência no desempenho escolar dos alunos, mas poder-se-ia esperar um resultado diferente, dado o conjunto de informações de que se fez uso (um painel de escolas de cinco anos) e a importância que assumem as escolas na qualidade do ensino nos países que apresentam os melhores desempenhos nas avaliações internacionais (ver Barber e Mourshed, 2007).

Por outro lado, os resultados encontrados no capítulo 2 vão ao encontro daqueles apontados no capítulo 3 deste trabalho: de que o Sistema Educacional brasileiro é altamente estratificado, de forma a só terem acesso às boas escolas as crianças de famílias com boas condições socioeconômicas, que têm condições de freqüentar o ensino da rede privada. Não 
por acaso são estas escolas que apresentam os melhores desempenhos. Quando se controlam nas regressões por Efeitos Fixos os efeitos específicos não-observáveis das escolas, praticamente todas as demais características observáveis de professores, turmas, diretores e escolas, se tornam inócuas no que diz respeito a afetarem o desempenho dos alunos. É como se o efeito específico não-observado fosse demasiado na regressão: ele capta as variáveis e o processo, não observados pelo pesquisador, que fazem o casamento entre as famílias com boas (e más) condições socioeconômicas e as boas (e más) escolas, bons (e ruins) diretores e bons (e ruins) professores.

No capítulo 3, foram avaliados os resultados que emergem de diferentes medidas para se construirem rankings de escolas a partir dos resultados nas provas do SAEB para 486 escolas que se repetem nos anos de 1999, 2001 e 2003. Esta questão é importante porque a sociedade brasileira tem crescentemente percebido a questão da qualidade das escolas como de fundamental importância para o aprendizado, e os resultados que emergem dos rankings de escolas servem como parâmetros para o governo acompanhar a situação do sistema educacional e também como fontes de informações para as famílias avaliarem a qualidade das escolas e tomarem decisões sobre onde matricular os filhos.

Os resultados do terceiro capítulo apontam, outrossim, para a dificuldade de se obterem rankings de significado confiável sobre qualidade da escola num contexto de elevada estratificação no sistema educacional e de ruído nas estimativas causado pelo problema de reversão para a média. A maioria dos rankings que emergem num tal quadro exibem um "trade-off" entre refletir majoritariamente o status socioeconômico (SSE) dos alunos e apresentar uma volatilidade. Neste trabalho, apenas uma das medidas utilizadas para ordenar as escolas apresentou as características desejáveis de não ser influenciada pelo SSE dos alunos e apresentar baixa volatilidade. Porém, para uma análise mais certeira sobre qual medida é a mais adequada para se construirem rankings de escola no Brasil, seria preciso poder contar com dados para mais anos e de natureza censitária, como o é a Prova Brasil.

No capítulo 4 buscou-se adentrar a questão sobre a influência que mais recursos destinados à educação e ao pagamento de salários dos professores exerce sobre uma série de indicadores educacionais, que refletem os insumos disponíveis e a qualidade nas escolas brasileiras. Fazendo uso de uma mudança de política que significou radical alteração na forma de financiamento do ensino fundamental no Brasil a partir de 1998, que foi o FUNDEF, procura- 
se captar seus efeitos com o uso do método de diferenças em diferenças simples e sua aplicação a um painel de municípios.

Para construir o painel de municípios, foram utilizadas as informações do Censo Escolar e da base de dados do Ministério da Fazenda sobre as finanças municipais (FINBRA) para os anos de 1997, 1999, 2001, 2003 e 2005. Com informações sobre as características (na média, por município) das escolas municipais e privadas de 2.837 municípios, que se repetem nos cinco levantamentos do Censo Escolar para os quais havia informação sobre os recursos líquidos repassados pelo FUNDEF a partir de 1999, foi possível obter diferentes grupos de controle e tratamento para melhor se estudarem os efeitos do Fundo.

Os resultados obtidos indicam que o FUNDEF aumentou o número de matrículas no ensino fundamental nas escolas municipais; elevou a razão alunos por professor neste nível de ensino, não obstante tenham também aumentado as contratações de professores; aumentou a proporção de escolas municipais com quadras de esporte, laboratórios de ciências e de informática, especialmente no primeiro ano seguinte à implementação do Fundo e elevou a proporção de professores de $5^{\mathrm{a}}$ a $8^{\mathrm{a}}$ série com o $3^{\mathrm{o}}$ grau.

Com relação aos indicadores de rendimento e fluxo escolar, quando se comparam os resultados apenas das escolas municipais cujos municípios foram beneficiados com transferências positivas do Fundo com aqueles das escolas municipais cujos municípios não foram beneficiados, constatou-se uma elevação das taxas de aprovação nos primeiros, bem como uma diminuição da taxa de abandono nos anos de 2001 e 2003. Além disso, houve um aumento na proporção de professores de $1^{\mathrm{a}}$ a $4^{\mathrm{a}}$ série com o $3^{\mathrm{o}}$ grau. Acredita-se que estes resultados são os mais robustos para se avaliar o efeito do FUNDEF sobre a qualidade do ensino. O programa do governo federal parece estar logrando elevar a qualidade do ensino público.

Quando são utilizadas, porém, como grupo de controle as escolas privadas, os resultados apontam no sentido de ter havido um aumento da taxa de repetência nas escolas municipais, uma diminuição das taxas de aprovação e um aumento do abandono nos anos posteriores à entrada em vigência das novas regras. Contudo, dadas as disparidades muito acentuadas entre os indicadores de fluxo e rendimento escolar entre escolas públicas e privadas, é bastante 
sensato inferir que estas últimas não sirvam de grupo de controle adequado para as escolas municipais beneficiadas pelo FUNDEF. 


\section{REFERÊNCIAS}

ABDUl LATIF JAMEEL POVERTY ACTION LAB. Fighting Poverty: What Works? Issue One, Fall 2005.

ANDRADE, Eduardo de Carvalho et al.. Free-rider and gaming in the distribution of revenues across schools. Mimeo. Out., 2007.

AFONSO, Luiz. Eduardo et al. Um estudo sobre os diferenciais de remuneração entre os professores das redes pública e privada de ensino. Mimeo. Março, 2007.

ANGRIST, Joshua D.; KRUEGER, Alan B. Empirical strategies in labor economics. In: ARSHENFELTER, Orley.; CARD, David. (Eds). Handbook of labor economics, v.3. Amsterdam: Elsevier, 1999.

ANUATTI NETO, Francisco et al. Avaliação dos salários dos professores da rede pública de Ensino Fundamental em tempos de FUNDEF. Economia Aplicada, 8(3), p. 124-145, 2003.

BARBER, Michael; MOURSHED, Mona. How the world's best-performing school systems come out on top. McKinsey\&Company. Sept. 2007.

BARBOSA FILHO, Fernando de Holanda; PESSÔA, Samuel. Retorno da educação no Brasil. Programa de seminários acadêmicos do Instituto de Pesquisas Econômicas da USP, 15/09/2006. Disponível em: <http://www.econ.fea.usp.br>.Acesso em 29/10/2006.

BARBOSA FILHO, Fernando de Holanda; PESSÔA, Samuel. A carreira do professor estadual no Brasil: os casos de São Paulo e Rio Grande do Sul. Mimeo. Jan., 2008.

BANERJEE, Abhijit.; DUFLO, Esther. The experimental approach to development. Sept.,

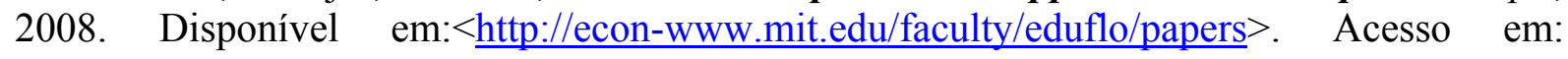
$05 / 10 / 2008$.

BANERJEE, Abhijit et al. Moving to Universal Education! Costs and Trade offs. Mimeo. MIT, 2005

BERRY, James. Rotten Kids or Rotten Parents: Child Motivation and Education Decision in India. Mimeo. MIT, 2008.

BIONDI, Roberta Loboda; FELÍCIO, Fabiana. Atributos escolares e o desempenho dos estudantes: uma análise de painel dos dados do SAEB. Brasília: INEP, 2007.

CASTRO, Cláudio de Moura. Investiment in education in Brazil: a study of two industrial communities. Tese (PhD). Graduate School of Vanderbilt University, 1970. 
CHAY, Keneth Y. et al. The central role of noise in evaluating interventions that use test scores to rank schools. American Economic Review. v.4, n.95, p. 1237-1258, 2005.

CLOTFELTER, Charles et al. Would higher salaries keep teachers in schools? Evidence from a policy intervention in North Carolina. Journal of Public economics. p.1-19. Jul. 2005.

DUFLO, Esther et al. Monitoring Works: Getting Teachers to

Come to School. National Bureau of Economic Research. Working Paper No. 11880, 2005.

FELÍCIO, Fabiana. FERNANDES, Reynaldo. O efeito da qualidade da escola sobre o desempenho escolar: uma avaliação do ensino fundamental no estado de São Paulo. São Paulo, 2006. Dissertação (Mestrado em economia) - Programa de Pós-Graduação em Economia, Faculdade de Economia e Administração da Universidade de São Paulo.

FERNANDES, Reynaldo. Índice de desenvolvimento da educação básica (Ideb). Texto para discussão n.26, 2007. Disponível em: $<$ http://www.publicações.inep.gov.br $>$. Acesso em: $15 / 07 / 2008$.

FRIEDMAN, Milton. The role of government in education. In: SOLO, R. A. (Ed). Economics and the public interest. New Brunswick, NJ: Rutgers University, 1955.

GLEWWE, Paul.; JACOBY, Hanan. Student achievement and schooling choice in lowincome countries: evidence from Ghana. Journal of Human Resources.n.29, v.3, p. 843-864, 1994.

GLEWWE, Paul et al. An Eclectic approach to estimating the determinants of achievement in Jamaican Primary education. World Bank Economic Review. v.9, n.2, p. 231-258, 1995.

GLEWWE, Paul et al. Teacher Incentives. Mimeo. Harvard, 2003.

GURYAN, Jonathan. Does money matter? Estimates from educational finance reform in Massachusetts. National Bureau of Economic Research. Working paper, Mar. 2003.

HANUSHEK, Erik. A. et al. Do higher salaries buy better teachers? National Bureau of Economic Research. Working paper n. 7082, 1999.

HANUSHEK, Erik. A.;RIVKIN, Steven G. How to improve the supply of high quality teachers. In: RAVITCH, D. (Ed.). Brookings papers on education policy. Washington: Brookings Institution Press, p. 7-25, 2004.

HANUSHEK, Eric. Interpreting recent research on schooling in developing countries. World Bank Research Observer. V.10 (2), p. 227-246, 1995. 
HANUSHEK, Eric. Teacher Quality. In: IZUMI, L.T; EVERS W. M. (Ed.). Teacher Quality. Stanford: Hoover Institution Press, p. 1-12, 2002.

HANUSHEK, Eric et al. Teachers, school and academic achievement. Econometrica. V. 73, n. 2, p. 417-458, mar 2005b.

HANUSHEK, Eric. The economics of school quality. German economic review. V.3, n. 3, p. 269-286, ago.2005a. Disponível em:

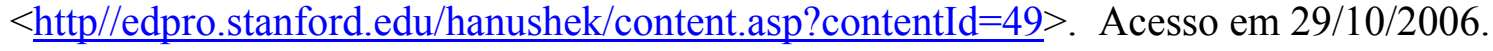

HANUSHEK, Eric. A.; PACE, R.R. Who chooses to teach (and why)? Economics of education review. V. 14, n. 2, p. 101-117, 1995.

HANUSHEK, Eric. Why quality matters in education. Finance and development, p.15-19, jun. 2005c. Disponível em: <http://edpro.stanford.edu/hanushek/content.asp? contentId=49>. Acesso em: 29/10/2006

HECKMAN, James. J. Randomization and social policy evaluation. National Bureau of Economic Research. Technical Working Paper No.107,1992.

INSTITUTO NACIONAL DE ESTUDOS E PESQUISAS EDUCACIONAIS ANÍSIO TEIXEIRA - INEP. Disponível em: <http://www.INEP.gov.br/basica/SAEB/default.asp $>$. Acesso em: 15/03/2008.

INSTITUTO NACIONAL DE ESTUDOS E PESQUISAS EDUCACIONAIS ANÍSIO TEIXEIRA - INEP. SAEB Primeiros resultados: médias de desempenho do SAEB 2005 em perspectiva comparada. Fevereiro, 2007.

Disponível: < http://www.INEP.gov.br/download/SAEB/2005/SAEB1995 2005.pdf> $>$. Acesso em 15/03/2008.

INSTITUTO NACIONAL DE ESTUDOS E PESQUISAS EDUCACIONAIS ANÍSIO TEIXEIRA - INEP. Nota técnica: Índice de desenvolvimento da educação básica. Disponível em: $<$ http://www.inep.gov.br $>$. Acesso em 15/07/2008.

INSTITUTO NACIONAL DE ESTUDOS E PESQUISAS EDUCACIONAIS ANÍSIO TEIXEIRA - INEP. FUNDEF - Manual de orientação. Maio, 2004.Disponível em:

$<$ http://www.siope.INEP.gov.br/arquivos/manuais/manual fundef.pdf $>$. Acesso em $28 / 02 / 2008$.

KINGDON, Geeta. The Quality and efficiency of public and private schools: a case study of urban India. Oxford Bulletin of Economics and Statistics. V. 58, n. 1, p. 55-80, Feb. 1996.

KREMER, Michael. Randomized evaluations of educational programs in developing countries: some lessons. American Economic Review. V. 93, n. 2, p.102-115, 1995 
LANGONI, Carlos Geraldo. As causas do crescimento econômico do Brasil. Rio de Janeiro: APEC, 1974.

LAZEAR, Edward. P. Teacher Incentives. Swedish Economic Policy Review. v. 10, n. 3, p. $179-214,2003$.

LEE, Valerie E. Using multilevel methods to investigate research questions that involves nested data: examples from education. Estudos em avaliação educacional. N. 24, p. 47-68, Jul./Dez. 2001a.

LEE, Valerie E. What are multilevel questions, and how might we explore them with quantitative methods. Estudos em avaliação educacional. N. 24, p. 31-45, Jul./ Dez. 2001b.

MADEIRA, Ricardo. The effects of decentralization on schooling: evidence from the São Paulo State's education reform. University of São Paulo. Mimeo. Sept. 2007.

MCEWAN Patrick J. et al. School choice, stratification and information on school performance: lessons from Chile. Preliminary draft for presentation at the $16^{\text {th }}$ Panel of Economic. Journal of LACEA, 2007.

MENEZES-FILHO, Naercio A. et al. Definição de metas de desempenho para as escolas estaduais paulistas. Mimeo. 2008

MENEZES-FILHO, Naercio A.; PAZELLO, Elaine. Do teachers' wage matter for proficiency? Evidence from a funding reform in Brazil. Economics of Education Review. n. 26, p. 660-672, 2007.

MENEZES-FILHO, Naercio A. Os determinantes do desempenho escolar no Brasil. Instituto Futuro Brasil, IBMEC São Paulo e Faculdade de Economia e Administração da Universidade de São Paulo. Sumário Executivo. 2007.

Miguel, Edward; Kremer, Michael. Worms: Identifying Impacts on Education and Health in the Presence of Treatment Externalities. Econometrica. V. 72 (1), p. 159-217, 2004.

MINISTÉRIO DA FAZENDA. Finanças do Brasil - FINBRA. Receitas e despesas dos municípios. Disponível em:

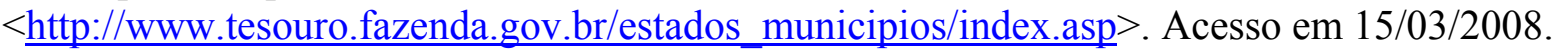

MIZALA, Alejandra et al. Tradeoffs in the generation of school quality information. Journal of Development Economics. n. 84, p.61-75, 2007.

MULLIGAN, Casey B. Galton versus the human capital approach do inheritance. Journal of Political Economy. v. 107, n. 6, p. S184-S224, 1999. 
MURNANE, Richard J. et al. How important are cognitive skills of teenagers in predicting subsequent earnings? Journal of Policy Analysis and Management. V. 19, n. 4, p. 547-568, 2000.

SEMEGHINI, Ulysses C. FUNDEF: uma revolução silenciosa. Mimeo. 2001.

SOARES, Tufi Machado. Influência do professor e do ambiente em sala de aula sobre a proficiência alcançada pelos alunos avaliados no Simave 2002. Estudos em Avaliação Educacional. n. 28, p. 103-123, Jul./ Dez. 2003a

SOARES, Tufi Machado; MENDONÇA, Márcia Cristina M. Construção de um modelo Hierárquico para os dados do SIMAVE 2000. Pesquisa Operacional. v. 23, n.3, p. 421-441, Set./Dez. 2003b.

SOARES, Tufi Machado. Modelo de três níveis hierárquicos para a proficiência dos alunos de $4^{\text {a }}$ série avaliados no teste de língua portuguesa do SIMAVE/ PROEB 2002. Revista Brasileira de Educação. n. 29, p. 73-87, Mai./Ago. 2005.

SOARES, José Francisco et al. O efeito de 248 escolas de nível médio no vestibular da UFMG nos anos de 1998, 1999 e 2000. Estudos em Avaliação Educacional. n. 24, p. 69117, Jul./Dez. 2001.

SOARES, Sergey; SÁTYRO, Natália. O impacto da infra-estrutura escolar na taxa de distorção idade-série das escolas brasileiras de ensino fundamental - 1998 a 2005. IPEA Texto para discussão. $\mathrm{N}^{\mathrm{0}} 1338,28$ p., Mai. 2008

TAN, Jee-Peng et al. Putting inputs to work in elementary schools: what can be done in the Philippines? Economic Development And Cultural Change. v. 45, n. 4, p. 857-879, 1997.

TAYLOR, Lori L. Comparing teacher salaries: insights from the U.S. census. Economics of Education Review. n. 27, p. 48-57, 2008

WOOLDRIDGE, Jeffrey M. Econometric analysis of cross section and panel data. Cambridge: Massachusetts Institute of Technology, 2002. 


\section{APÊNDICE 1}

Tabela A1 - Variáveis de alunos: toda amostra e painel 1997-2005

\begin{tabular}{|c|c|c|c|c|c|c|c|c|c|c|}
\hline Variáveis de alunos & $\begin{array}{l}1997 \\
\text { Amostra }\end{array}$ & $\begin{array}{l}1997 \\
\text { Painel } \\
\end{array}$ & $\begin{array}{l}1999 \\
\text { Amostra }\end{array}$ & $\begin{array}{l}1999 \\
\text { Painel } \\
\end{array}$ & $\begin{array}{l}2001 \\
\text { Amostra }\end{array}$ & $\begin{array}{l}2001 \\
\text { Painel }\end{array}$ & $\begin{array}{l}2003 \\
\text { Amostra }\end{array}$ & $\begin{array}{l}2003 \\
\text { Painel }\end{array}$ & $\begin{array}{l}2005 \\
\text { Amostra }\end{array}$ & $\begin{array}{l}2005 \\
\text { Painel }\end{array}$ \\
\hline Proficiência & $\begin{array}{l}188,20 \\
(44,74)\end{array}$ & $\begin{array}{l}195,31 \\
(48,38)\end{array}$ & $\begin{array}{l}183,66 \\
(42,32)\end{array}$ & $\begin{array}{l}190,69 \\
(44,36)\end{array}$ & $\begin{array}{l}184,62 \\
(47,98)\end{array}$ & $\begin{array}{l}187,64 \\
(49,02)\end{array}$ & $\begin{array}{l}186,57 \\
(46,49)\end{array}$ & $\begin{array}{l}188,33 \\
(47,80)\end{array}$ & $\begin{array}{l}188,55 \\
(48,75)\end{array}$ & $\begin{array}{l}193,92 \\
(49,97)\end{array}$ \\
\hline Homens & $49,42 \%$ & $49,81 \%$ & $50,61 \%$ & $50,75 \%$ & $51,22 \%$ & $51,70 \%$ & $50,16 \%$ & $49,62 \%$ & $50,19 \%$ & $50,02 \%$ \\
\hline Idade 9 anos & $9,79 \%$ & $11,49 \%$ & $11,19 \%$ & $13,45 \%$ & $19,08 \%$ & $20,03 \%$ & $8,00 \%$ & $7,95 \%$ & $7,39 \%$ & $7,56 \%$ \\
\hline Idade 10 anos & $37,66 \%$ & $44,08 \%$ & $36,61 \%$ & $43,48 \%$ & $42,36 \%$ & $44,20 \%$ & $49,37 \%$ & $49,68 \%$ & $49,59 \%$ & $52,22 \%$ \\
\hline Idade 11 anos & $19,28 \%$ & $17,98 \%$ & $17,31 \%$ & $16,21 \%$ & $16,59 \%$ & $15,67 \%$ & $22,59 \%$ & $22,55 \%$ & $24,73 \%$ & $23,13 \%$ \\
\hline Idade 12 ou mais & $33,27 \%$ & $26,43 \%$ & $34,89 \%$ & $26,84 \%$ & $21,97 \%$ & $20,08 \%$ & $20,04 \%$ & $19,79 \%$ & $18,12 \%$ & $16,95 \%$ \\
\hline Branco & $43,83 \%$ & $45,80 \%$ & $42,47 \%$ & $46,57 \%$ & $42,34 \%$ & $44,21 \%$ & $40,39 \%$ & $40,49 \%$ & $36,14 \%$ & $38,66 \%$ \\
\hline Pardo/ Mulato & $38,20 \%$ & $37,15 \%$ & $37,66 \%$ & $35,59 \%$ & $36,00 \%$ & $34,73 \%$ & $43,01 \%$ & $42,58 \%$ & $42,58 \%$ & $41,78 \%$ \\
\hline Negro & $9,05 \%$ & $7,56 \%$ & $10,67 \%$ & $8,42 \%$ & $10,50 \%$ & $9,92 \%$ & $9,49 \%$ & $9,24 \%$ & $11,45 \%$ & $9,85 \%$ \\
\hline Amarelo/ Ind. & $7,92 \%$ & $8,51 \%$ & $8,25 \%$ & $8,37 \%$ & $7,64 \%$ & $7,80 \%$ & $7,11 \%$ & $7,67 \%$ & $5,92 \%$ & $5,92 \%$ \\
\hline Mãe do aluno: & & & & & & & & & & \\
\hline Nunca estudou & $7,75 \%$ & $6,68 \%$ & $8,46 \%$ & $6,14 \%$ & $7,47 \%$ & $6,97 \%$ & $3,39 \%$ & $3,38 \%$ & $2,96 \%$ & $2,71 \%$ \\
\hline $1^{\mathrm{a}}$ à $4^{\mathrm{a}} \mathrm{EF}$ & $23,62 \%$ & $17,73 \%$ & $23,88 \%$ & $19,65 \%$ & $23,24 \%$ & $21,96 \%$ & $22,60 \%$ & $21,04 \%$ & $19,74 \%$ & $17,14 \%$ \\
\hline $5^{\mathrm{a}}$ à $8^{\mathrm{a}} \mathrm{EF}$ & $16,67 \%$ & $14,72 \%$ & $16,66 \%$ & $16,40 \%$ & $17,14 \%$ & $16,57 \%$ & $14,77 \%$ & $13,87 \%$ & $14,17 \%$ & $13,12 \%$ \\
\hline Ensino médio & $12,53 \%$ & $14,01 \%$ & $8,07 \%$ & $9,60 \%$ & $15,22 \%$ & $15,20 \%$ & $18,64 \%$ & $18,70 \%$ & $17,31 \%$ & $17,64 \%$ \\
\hline Faculdade & $12,24 \%$ & $17,69 \%$ & $14,08 \%$ & $19,78 \%$ & $13,14 \%$ & $15,14 \%$ & $15,29 \%$ & $18,42 \%$ & $18,64 \%$ & $22,77 \%$ \\
\hline Aluno não sabe & $26,26 \%$ & $28,29 \%$ & $28,03 \%$ & $27,63 \%$ & $28,71 \%$ & $28,79 \%$ & $25,56 \%$ & $24,82 \%$ & $34,47 \%$ & $33,66 \%$ \\
\hline Tem computador & $15,46 \%$ & $21,94 \%$ & $19,58 \%$ & $25,85 \%$ & $24,80 \%$ & $27,98 \%$ & $19,76 \%$ & $23,23 \%$ & $\begin{array}{l}23,02 \% \\
\text { (a) }\end{array}$ & $28,07 \%$ \\
\hline $\begin{array}{l}\text { Mora com o pai e } \\
\text { mãe }\end{array}$ & $82,13 \%$ & $82,32 \%$ & $72,07 \%$ & $71,73 \%$ & $61,84 \%$ & $62,27 \%$ & $67,53 \%$ & $67,39 \%$ & $68,04 \%$ & $69,38 \%$ \\
\hline Trabalha fora & - & - & $24,15 \%$ & $19,27 \%$ & $14,33 \%$ & $13,21 \%$ & $15,48 \%$ & $15,04 \%$ & $10,95 \%$ & $9,15 \%$ \\
\hline Observações & 23.535 & 9.407 & 21.150 & 7.906 & $\mathbf{5 3 . 3 5 7}$ & 27.583 & 42.711 & 17.233 & 41783 & 21.089 \\
\hline
\end{tabular}

Nota: (a) para 2005: computador com Internet. 
Tabela A2 - Variáveis de professores: toda amostra e painel 1997-2005

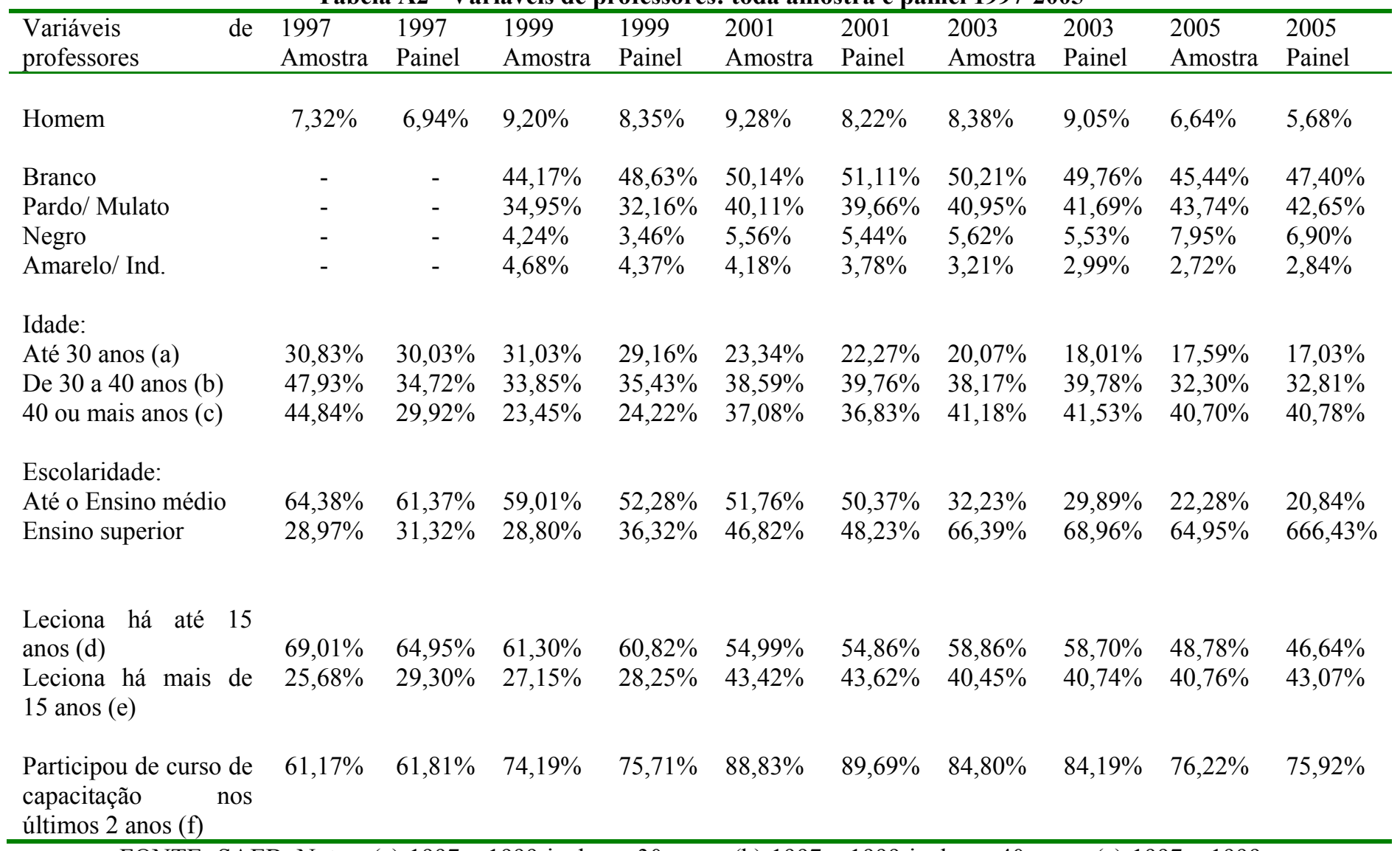

FONTE: SAEB. Notas: (a) 1997 e 1999 incluem 30 anos; (b) 1997 e 1999 incluem 40 anos; (c) 1997 e 1999 a partir de 41 anos; (d) 2001 há até 14 anos; (e) 2001 há mais de 14 anos; (f) para 1997: no próprio ano. 
Tabela A3 - Variáveis de diretores: toda amostra e painel 1997-2005

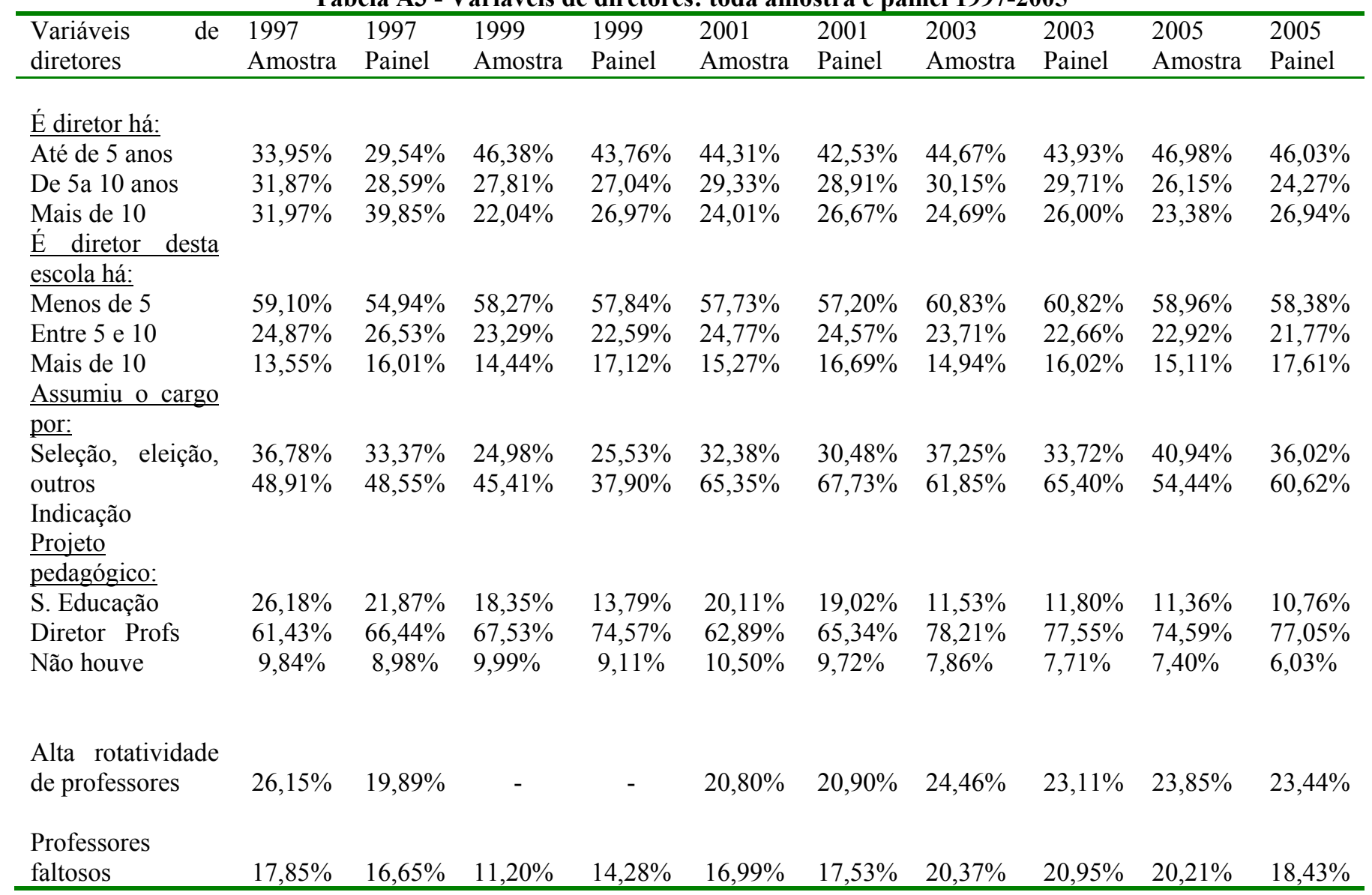

FONTE: SAEB e Censo Escolar (INEP). Não há questionário de turmas no SAEB para o ano 1997. 
Tabela A4 - Variáveis de turmas: toda amostra e painel 1997-2005

\begin{tabular}{|c|c|c|c|c|c|c|c|c|}
\hline Variáveis de turmas & $\begin{array}{l}1999 \\
\text { Amostra }\end{array}$ & $\begin{array}{l}1999 \\
\text { Painel } \\
\end{array}$ & $\begin{array}{l}2001 \\
\text { Amostra }\end{array}$ & $\begin{array}{l}2001 \\
\text { Painel }\end{array}$ & $\begin{array}{l}2003 \\
\text { Amostra }\end{array}$ & $\begin{array}{l}2003 \\
\text { Painel } \\
\end{array}$ & $\begin{array}{l}2005 \\
\text { Amostra }\end{array}$ & $\begin{array}{l}2005 \\
\text { Painel }\end{array}$ \\
\hline Sem professor no ano & $6,20 \%$ & $6,79 \%$ & $3,8 \%$ & $3,49 \%$ & $3,87 \%$ & $3,66 \%$ & $4,04 \%$ & $4,51 \%$ \\
\hline Um professor no ano & $83,22 \%$ & $82,50 \%$ & $82,37 \%$ & $81,66 \%$ & $79,75 \%$ & $81,81 \%$ & $82,27 \%$ & $81,90 \%$ \\
\hline Dois ou mais professores & $10,58 \%$ & $10,70 \%$ & $13,82 \%$ & $14,85 \%$ & $16,37 \%$ & $14,51 \%$ & $13,68 \%$ & $13,57 \%$ \\
\hline Teve aula todos os meses & $97,03 \%$ & $97,67 \%$ & $96,08 \%$ & $96,18 \%$ & $97,16 \%$ & $97,32 \%$ & $95,59 \%$ & $95,25 \%$ \\
\hline Um mês (ou bimestre) sem professor & $2,96 \%$ & $2,32 \%$ & $3,81 \%$ & $3,81 \%$ & $2,8 \%$ & $2,67 \%$ & $4,41 \%$ & $4,74 \%$ \\
\hline \multicolumn{9}{|l|}{ Turno: } \\
\hline Até 4 horas de aula por dia & $54,76 \%$ & $47,16 \%$ & $53,83 \%$ & $51,30 \%$ & $48,49 \%$ & $45,37 \%$ & $49,50 \%$ & $45,50 \%$ \\
\hline Entre 4 e 5 horas de aula por dia & $42,30 \%$ & $50,47 \%$ & $42,57 \%$ & $45,18 \%$ & $46,76 \%$ & $51,11 \%$ & $47,97 \%$ & $52,08 \%$ \\
\hline Mais de 5 horas de aula por dia & $2,93 \%$ & $2,36 \%$ & $3,59 \%$ & $3,51 \%$ & $4,74 \%$ & $3,51 \%$ & $2,52 \%$ & $2,41 \%$ \\
\hline Tamanho da turma (média) & $\begin{array}{l}29,10 \\
(9,19)\end{array}$ & $\begin{array}{l}30,75 \\
(8,60)\end{array}$ & $\begin{array}{l}29,41 \\
(8,85)\end{array}$ & $\begin{array}{l}29,97 \\
(8,17)\end{array}$ & $\begin{array}{l}28,72 \\
(8,37)\end{array}$ & $\begin{array}{l}29,67 \\
(8,17)\end{array}$ & $\begin{array}{l}29,48 \\
(8,07)\end{array}$ & $\begin{array}{l}29,86 \\
(8,06)\end{array}$ \\
\hline \multicolumn{9}{|l|}{ Tamanho da turma: } \\
\hline Até 10 alunos & $3,22 \%$ & $1,16 \%$ & $2,46 \%$ & $0,77 \%$ & $2,46 \%$ & $0,77 \%$ & $1,27 \%$ & $0,53 \%$ \\
\hline De 11 a 19 alunos & $11,92 \%$ & $7,55 \%$ & $10,87 \%$ & $9,22 \%$ & $11,15 \%$ & $10,28 \%$ & $9,90 \% \%$ & $9,20 \%$ \\
\hline De 20 a 29 alunos & $33,09 \%$ & $33,46 \%$ & $33,59 \%$ & $35,56 \%$ & $37,06 \%$ & $36,14 \%$ & $36,42 \%$ & $36,38 \%$ \\
\hline De 30 a 39 alunos & $40,18 \%$ & $44,53 \%$ & $40,10 \%$ & $40,80 \%$ & $39,57 \%$ & $41,74 \%$ & $41,86 \%$ & $42,42 \%$ \\
\hline Mais de 40 alunos & $11,58 \%$ & $13,28 \%$ & $12,97 \%$ & $13,68 \%$ & $9,76 \%$ & $11,04 \%$ & $10,52 \%$ & $11,44 \%$ \\
\hline
\end{tabular}

FONTE: SAEB e Censo Escolar (INEP). Não há questionário de turmas no SAEB para o ano 1997. 
Tabela A5 - Variáveis de escolas (Censo Escola): toda amostra e painel 1997-2005

\begin{tabular}{|c|c|c|c|c|c|c|c|c|c|c|}
\hline $\begin{array}{l}\text { Variáveis } \\
\text { de escolas }\end{array}$ & $\begin{array}{l}1997 \\
\text { Amost } \\
\text { ra }\end{array}$ & $\begin{array}{l}1997 \\
\text { Painel }\end{array}$ & $\begin{array}{l}1999 \\
\text { Amost } \\
\text { ra }\end{array}$ & $\begin{array}{l}1999 \\
\text { Paine } \\
\text { l }\end{array}$ & $\begin{array}{l}2001 \\
\text { Amost } \\
\text { ra }\end{array}$ & $\begin{array}{l}2001 \\
\text { Paine } \\
\text { l }\end{array}$ & $\begin{array}{l}2003 \\
\text { Amost } \\
\text { ra }\end{array}$ & $\begin{array}{l}2003 \\
\text { Paine } \\
\text { l }\end{array}$ & $\begin{array}{l}2005 \\
\text { Amost } \\
\text { ra }\end{array}$ & $\begin{array}{l}2005 \\
\text { Paine } \\
\text { l }\end{array}$ \\
\hline $\begin{array}{l}\text { Escola } \\
\text { região rural } \\
\text { Administraç }\end{array}$ & $17,66 \%$ & $8,72 \%$ & $19,15 \%$ & $8,33 \%$ & $7,78 \%$ & $5,62 \%$ & $15,73 \%$ & $6,86 \%$ & $5,99 \%$ & $3,02 \%$ \\
\hline ão: & $40,72 \%$ & 30,14 & $29,72 \%$ & 30,20 & $30,97 \%$ & 33,01 & $32,09 \%$ & 35,40 & $34,01 \%$ & 34,79 \\
\hline Estadual & $33,04 \%$ & $\%$ & $42,01 \%$ & $\%$ & $37,41 \%$ & $\%$ & $40,91 \%$ & $\%$ & $35,58 \%$ & $\%$ \\
\hline Municipal & $26,24 \%$ & 28,98 & $28,27 \%$ & 31,06 & $31,60 \%$ & 31,78 & $26,50 \%$ & 33,51 & $29,77 \%$ & 27,83 \\
\hline Particular & $0 \%$ & $\%$ & $0 \%$ & $\%$ & $0 \%$ & $\%$ & $0,47 \%$ & $\%$ & $0,63 \%$ & $\%$ \\
\hline Federal & & 40,87 & & 38,73 & & 38,73 & & 31,08 & & 37,37 \\
\hline & $68,87 \%$ & $\%$ & $56,75 \%$ & $\%$ & $64,16 \%$ & $\%$ & $57,69 \%$ & $\%$ & $61,81 \%$ & $\%$ \\
\hline Biblioteca & & $0 \%$ & & $0 \%$ & & $0 \%$ & & $0 \%$ & & $0 \%$ \\
\hline Laboratórios & $23,36 \%$ & & $24,17 \%$ & & $33,69 \%$ & & $37,12 \%$ & & $43,15 \%$ & \\
\hline : & $26,31 \%$ & 77,47 & $19,45 \%$ & 73,88 & $24,76 \%$ & 68,58 & $19,34 \%$ & 66,78 & $25,33 \%$ & 66,63 \\
\hline De & $57,14 \%$ & $\%$ & $46,55 \%$ & $\%$ & $56,03 \%$ & $\%$ & $51,34 \%$ & $\%$ & $61,75 \%$ & $\%$ \\
\hline Informática & - & & $14,26 \%$ & & $16,73 \%$ & & $30,67 \%$ & & $66,00 \%$ & \\
\hline De Ciências & & 38,35 & & 37,64 & & 38,69 & & 39,64 & & 50,53 \\
\hline Quadra & - & $\%$ & $27,81 \%$ & $\%$ & $40,56 \%$ & $\%$ & $39,52 \%$ & $\%$ & $41,69 \%$ & $\%$ \\
\hline Internet (a) & - & 37,69 & $42,54 \%$ & 32,69 & $59,13 \%$ & 30,00 & $61,77 \%$ & 26,32 & $75,26 \%$ & 31,77 \\
\hline Comp. (a): & - & $\%$ & $2,58 \%$ & $\%$ & $3,47 \%$ & $\%$ & $4,01 \%$ & $\%$ & $2,94 \%$ & $\%$ \\
\hline Pedagogia & & 69,29 & & 65,49 & & 61,43 & & 63,00 & & 66,82 \\
\hline Administraç & & $\%$ & & $\%$ & & $\%$ & & $\%$ & & $\%$ \\
\hline & - & - & $2,77 \%$ & 23,51 & $3,51 \%$ & 18,92 & $2,27 \%$ & 38,69 & - & 68,16 \\
\hline Uso em aula & & & & $\%$ & & $\%$ & & $\%$ & & $\%$ \\
\hline Programas & $46,42 \%$ & - & $56,61 \%$ & & $57,37 \%$ & & $55,31 \%$ & & - & \\
\hline sociais: & & - & & 41,57 & & 45,49 & & 47,76 & & 45,88 \\
\hline Comunidade & $2,45 \%$ & - & $8,15 \%$ & $\%$ & $8,94 \%$ & $\%$ & $12,23 \%$ & $\%$ & $30,95 \%$ & $\%$ \\
\hline Solidária (b) & & & & 57,98 & & 63,37 & & 72,39 & & 77,86 \\
\hline FNDE (c) & $55,57 \%$ & & $46,32 \%$ & $\%$ & $43,43 \%$ & $\%$ & $36,96 \%$ & $\%$ & $30,32 \%$ & $\%$ \\
\hline Transporte & & - & & $4,07 \%$ & & $3,83 \%$ & & $5,53 \%$ & & $4,28 \%$ \\
\hline Escolar & - & & $5,00 \%$ & & $15,41 \%$ & & $11,31 \%$ & & $10,09 \%$ & \\
\hline TV Escola & $73,79 \%$ & $\begin{array}{c}38,55 \\
\%\end{array}$ & $70,66 \%$ & $1,29 \%$ & $64,35 \%$ & $3,67 \%$ & $30,46 \%$ & $2,39 \%$ & - & - \\
\hline $\begin{array}{l}\text { Informática } \\
\text { (a) }\end{array}$ & $72,25 \%$ & $1,03 \%$ & $68,27 \%$ & $\begin{array}{c}50,41 \\
\%\end{array}$ & $69,76 \%$ & $\begin{array}{c}55,90 \\
\%\end{array}$ & $71,76 \%$ & $\begin{array}{c}59,74 \\
\%\end{array}$ & $73,09 \%$ & - \\
\hline Livro (c) & - & $\begin{array}{c}47,03 \\
\%\end{array}$ & - & $7,17 \%$ & $8,61 \%$ & $9,60 \%$ & $57,22 \%$ & 12,34 & $64,70 \%$ & $\begin{array}{c}30,55 \\
\%\end{array}$ \\
\hline Merenda & $\begin{array}{c}41,29 \\
(28,94)\end{array}$ & - & $\begin{array}{c}22,75 \\
(19,43)\end{array}$ & 44,18 & $\begin{array}{c}26,33 \\
(20,52)\end{array}$ & 45,03 & $\begin{array}{c}21,68 \\
(20,45)\end{array}$ & $\%$ & $\begin{array}{c}26,49 \\
(20,08)\end{array}$ & 29,36 \\
\hline Renda & $\begin{array}{l}0,18 \\
(55)\end{array}$ & 60,73 & $\begin{array}{c}2,47 \\
(1,80)\end{array}$ & $\%$ & $\begin{array}{c}2,67 \\
(1,88)\end{array}$ & $\%$ & $\begin{array}{c}1,96 \\
(1,82)\end{array}$ & $\begin{array}{c}39,25 \\
\%\end{array}$ & $\begin{array}{c}2,13 \\
(1,90)\end{array}$ & $\%$ \\
\hline Mínima & $\begin{array}{c}4,63 \\
(2,98)\end{array}$ & $\%$ & $\begin{array}{c}0,11 \\
(0,40)\end{array}$ & $4,59 \%$ & $\begin{array}{c}0,08 \\
(0,31)\end{array}$ & $\begin{array}{c}14,81 \\
\%\end{array}$ & $\begin{array}{c}0,03 \\
(0,20)\end{array}$ & 11,52 & $\begin{array}{c}0,02 \\
(0,17)\end{array}$ & $\begin{array}{c}10,76 \\
\%\end{array}$ \\
\hline Professores & 4,81 & 61,14 & 2,57 & 60,47 & 2,75 & & 1,99 & $\%$ & 2,16 & \\
\hline $\mathrm{EF}$ & $(3,01)$ & $\%$ & $(1,86)$ & $\%$ & $(1,94)$ & 62,52 & $(1,86)$ & & $(1,92)$ & - \\
\hline & 54,45 & & 64,00 & & 83,22 & $\%$ & 58,80 & 32,58 & 65,15 & \\
\hline $\begin{array}{l}\text { Turmas } 4^{\mathrm{a}} \\
\text { série diurno }\end{array}$ & $(31,05)$ & - & $(83,99)$ & $\begin{array}{c}57,71 \\
\%\end{array}$ & $(68,01)$ & 67,29 & $(61,11)$ & $\%$ & $(64,56)$ & $\begin{array}{c}66,59 \\
\%\end{array}$ \\
\hline Turmas $\quad 4^{\mathrm{a}}$ & 163,25 & 48,27 & 3,92 & & 3,0 & $\%$ & 1,18 & 71,54 & 0,95 & \\
\hline série noturno & $(111,89$ & $(31,53$ & $(14,27)$ & - & $(7,06)$ & & $(7,07)$ & $\%$ & $(6,31)$ & 57,21 \\
\hline Total & ) & ) & & & & $7,45 \%$ & & & & $\%$ \\
\hline Turmas & & 0,19 & 67,92 & 31,96 & 86,22 & & 59,98 & 58,58 & 66,10 & \\
\hline $4^{a}$ série & 200,10 & $(0,57)$ & $(84,33)$ & $(23,69$ & $(69,64)$ & 29,56 & $(62,47)$ & $\%$ & $(65,40)$ & 28,11 \\
\hline Matrículas & $(90,09)$ & 4,99 & 4.048 & ) & 3.933 & $(22,37$ & 3.167 & & 2.811 & $(20,70$ \\
\hline $4^{\mathrm{a}} \quad$ série & 1.065 & $(2,87)$ & & 2,93 & & ) & & 26,97 & & ) \\
\hline diurno & & 5,18 & & $(1,93)$ & & 2,90 & & $(23,43$ & & 2,77 \\
\hline
\end{tabular}




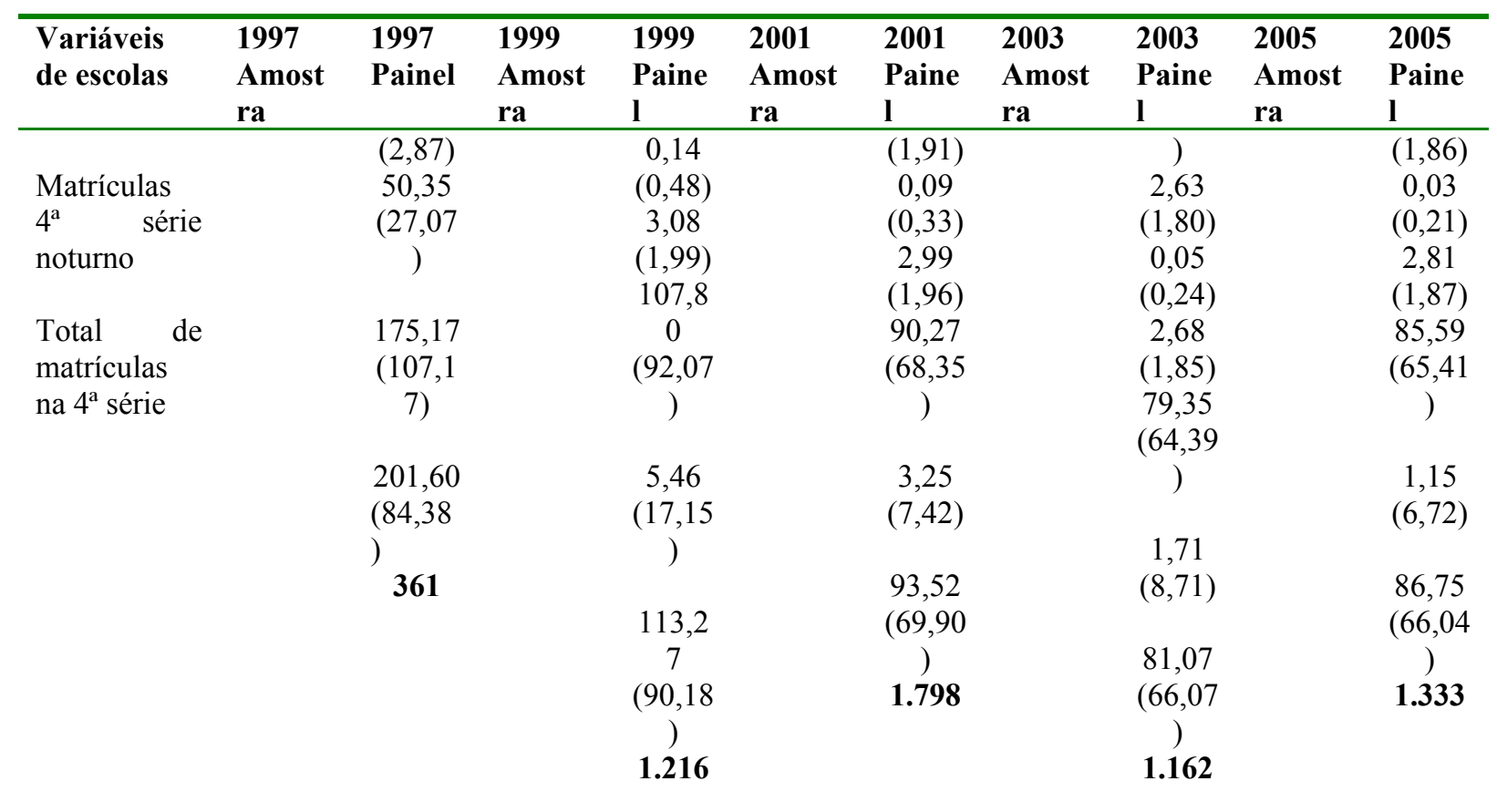

FONTE: CENSO ESCOLA (Inep/Mec). Notas: (a) Sem informações para 1997; (b) Sem informações para 1997 e 2005; (c) Sem informações para 2005. 


\section{APÊNDICE 2}

Seguindo a abordagem dada por WOOLDRIDGE (2002), o modelo básico de efeito não-observável pode ser escrito, pra uma amostra aleatória da população, como sendo:

$$
Y_{i t}=\boldsymbol{x}_{i t} \boldsymbol{\beta}+c_{i}+u_{i t}, \quad \mathfrak{t}=1,2, \ldots, \mathrm{T}
$$

Em (3.1) $\boldsymbol{x}_{i t}$ é um vetor 1 x K que pode conter variáveis observáveis que variam em $t$, mas não em $i$; variáveis que variam em $i$, mas não em $t$, e variáveis que mudam em $i$ e $t$. $C_{i}$ é o efeito não observado e $u_{i t}$ o erro idiossincrático, que varia em $t$ e em $i$.

Os diversos métodos de estimação propostos para se estimar $\boldsymbol{\beta}$ em (3.1) diferem, basicamente, quanto à relação entre as variáveis observáveis e o efeito não-observado e quanto à distribuição do erro idiossincrático.

Pode-se estimar consistentemente $\boldsymbol{\beta}$ por mínimos quadrados ordinários para painel, no chamado MQO agrupados, se se assumir que não há correlação ente $\boldsymbol{x}_{i t}$ e $c_{i}$. Neste caso, pode-se reescrever o modelo como:

$$
Y_{i t}=\boldsymbol{x}_{i t} \boldsymbol{\beta}+v_{i t} \quad \mathrm{t}=1,2, \ldots, \mathrm{T}
$$

Em (3.2) $v_{i t} \equiv c_{i}+u_{i t}, \mathrm{t}=1,2, \ldots, \mathrm{T}$, são os erros compostos. Para cada $\mathrm{t}, v_{i t}$ é a soma do efeito não-observado e o erro idiossincrático. O estimador MQO será consistente se E ( $\boldsymbol{x}_{i t}{ }^{\prime}$ $\left.v_{i t}\right)=\mathbf{0}, \mathrm{t}=1,2, \ldots, \mathrm{T}$. Ou seja, assume-se que:

$$
\begin{aligned}
& \mathrm{E}\left(\boldsymbol{x}_{i t}{ }^{\prime} u_{i t}\right)=\mathbf{0} \mathrm{e} \\
& \mathrm{E}\left(\boldsymbol{x}_{i t}{ }^{\prime} c_{i}\right)=\mathbf{0}, \mathrm{t}=1,2, \ldots, \mathrm{T}
\end{aligned}
$$

As hipóteses em (3.3) são bastante restritivas, uma vez que $\mathrm{E}\left(\boldsymbol{x}_{i t}{ }^{\prime} u_{i t}\right)=\mathbf{0}$ só vale se $\mathrm{E}$ $\left(\mathrm{y}_{i t} \mid \boldsymbol{x}_{i t}, c_{i}\right)=\mathbf{0}$ tiver sido modelada corretamente, e modelos com variáveis dependentes defasadas em $\boldsymbol{x}_{i t}$ violam a segunda hipótese de (3.3) porque $Y_{i t-1}$ e $c_{i}$ são necessariamente correlacionados. Mesmo que (3.3) seja, válido os erros compostos serão correlacionados serialmente devido à presença de $c_{i}$ em cada período do tempo. Portanto, as estimações por 
MQO agrupados de (3.2) exigem o uso do estimador robusto da matriz de variância e testes estatísticos robustos (ver WOOLDRIDGE, 2002, p. 152).

Da mesma forma que MQO agrupados, o método de estimação de Efeitos Aleatórios coloca $c_{i}$ no termo de erro. Porém, análises com efeitos aleatórios impõem hipóteses mais restritivas que as necessárias para a análise de MQO, quais sejam, a hipótese de exogeneidade estrita e de ortogonalidade entre $c_{i}$ e $\boldsymbol{x}_{i t}$. Estas hipóteses podem ser expressas como:

(a) $\mathrm{E}\left(\mathrm{y}_{i t} \mid \mathbf{x}_{\mathrm{i} 1}, \mathbf{x}_{\mathrm{i} 1}, \ldots, \mathbf{x}_{\mathrm{iT}}, \mathrm{c}_{\mathrm{i}}\right)=\mathrm{E}\left(\mathrm{y}_{i t} \mid \mathbf{x}_{\mathrm{it}}, \mathrm{c}_{\mathrm{i}}\right)=\boldsymbol{x}_{i t} \boldsymbol{\beta}+c_{i}$ ou, em termos do erro idiossincrático: $\mathrm{E}\left(\mathrm{u}_{i t} \mid \mathbf{x}_{\mathrm{i}}, \mathrm{c}_{\mathrm{i}}\right)=\mathbf{0}, \mathrm{t}=1,2, \ldots, \mathrm{T}$.

(b) $\mathrm{E}\left(c_{i} \mid \mathbf{x}_{\mathrm{i}}\right)=\mathrm{E}\left(c_{i}\right)=\mathbf{0}$

Em (3.4) $\mathbf{x}_{\mathrm{i}} \equiv\left(\mathbf{x}_{\mathrm{i} 1}, \mathbf{x}_{\mathrm{i} 2}, \ldots, \mathbf{x}_{\mathrm{iT}}\right)$.

A hipótese (a) de exogeneidade estrita significa que, uma vez que se controle por $\mathbf{x}_{i t} \mathrm{e}$ $c_{i}, \mathbf{x}_{\text {is }}$ não tem efeito parcial em $\mathrm{y}_{i t}$ para $\mathrm{s} \neq \mathrm{t}$. A hipótese (b) implica que $x i$ é independente de ci. Embora exija hipóteses mais fortes, a vantagem da abordagem de efeitos aleatórios sobre o método de MQO é que ela explora a correlação serial no erro composto $v_{i t}=c_{i}+u_{i t}$, como em mínimos quadrados generalizados (MQG) e, portanto é mais eficiente. Mas para se garantir que o MQG viável (feasible GLS) seja consistente, é necessária alguma forma de exogeneidade estrita entre as variáveis explanatórias e o erro composto.

Porém, em muitas aplicações, a grande vantagem em se utilizar dados em painel é permitir que $c_{i}$ seja arbitrariamente correlacionado com $\mathbf{x}_{\text {it. }} \mathrm{O}$ método de Efeitos Fixos permite que este propósito seja atingido. Considere escrever as T equações no modelo (3.1) como:

$$
\boldsymbol{y}_{i}=\boldsymbol{X}_{i} \boldsymbol{\beta}+c_{i} \mathbf{j}_{\mathrm{T}}+\boldsymbol{u}_{i}
$$

Em que $\mathbf{j}_{\mathrm{T}}$ é o vetor $\mathrm{T}$ x 1 de uns.

A primeira hipótese para se aplicar Efeitos Fixos é a hipótese de exogeneidade estrita, que é idêntica à hipótese 3.4(a) para Efeitos Aleatórios. A grande diferença no caso de Efeitos Fixos é que não se assume 3.4(b), em que $c_{i}$ tem que ser ortogonal à $x_{i}$. Isto é, em análises de Efeitos Fixos, E $\left(c_{i} \mid x_{i}\right)$ pode ser qualquer função de $\mathrm{x}_{\mathrm{i}}$. É possível assim estimar 
consistentemente os efeitos parciais na presença de variáveis omitidas constantes no tempo que podem estar arbitrariamente relacionadas às observáveis $\mathbf{x}_{\text {it }}$. Portanto, Efeitos Fixos geram estimativas mais robustas. Porém, sem que se assumam hipóteses adicionais, $\mathbf{x}_{\text {it }}$ não pode conter variáveis constantes no tempo pra todas as unidades cross sections, uma vez que seus efeitos se confundiriam com o da variável não-observável constante no tempo $c_{i}$.

$\mathrm{Na}$ abordagem de Efeitos Fixos faz-se uma transformação de (3.5) para eliminar o efeito não-observado $c_{i}$, denominada de within transformation, que utiliza a variação no tempo dentro de cada cross section para calcular uma média. A transformação consiste em tirar a média para $y_{i t}, x_{i t}, c_{i}$ e $u_{i}$ ao longo de $\mathrm{t}=1, \ldots, \mathrm{T}$, em cada cross section, e em seguida subtrair de (3.5). Como $c_{i}$ é constante no tempo para cada i, sua média no tempo é igual á $\mathrm{c}_{\mathrm{i}} \mathrm{e}$ então, depois de feita a transformação, o efeito não observado é eliminado e o que se obtém é a seguinte equação transformada:

$$
y^{*}{ }_{i t}=\boldsymbol{x}^{*} \boldsymbol{\beta} \boldsymbol{\beta}+u^{*}
$$

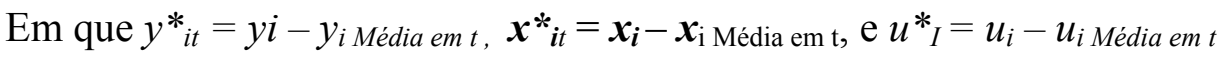

Neste caso, pode-se mostrar que, uma vez observada a hipótese de exogeneidade estrita, é possível estimar $\boldsymbol{\beta}$ consistentemente por MQO agrupados. Portanto, o estimador de efeitos fixos $\boldsymbol{\beta}_{\mathrm{EF}}$, é o estimador MQO agrupados a partir da regressão ${ }^{32}$ :

$$
y^{*}{ }_{i t} \text { em } x^{*}{ }_{i t} \quad \mathrm{t}=1,2, \ldots \mathrm{T} ; \mathrm{i}=1,2, \ldots, \mathrm{N} .
$$

São necessárias duas hipóteses adicionais para se garantir que o estimador de Efeitos Fixos seja assintóticamente não viesado e o mais eficiente sob a hipótese de exogeneidade estrita. São elas:

$$
\begin{aligned}
& \operatorname{Rank}\left(\sum_{\mathrm{t}=1}^{\mathrm{T}} \mathrm{E}\left(\mathbf{x}^{*}{ }_{i t}{ }^{\prime} \mathbf{x}^{*}{ }_{i t}\right)\right)=\operatorname{rank}\left[\mathrm{E}\left(\mathbf{X}^{*}{ }_{\mathrm{i}}{ }^{\prime} \mathbf{X}^{*}{ }_{\mathrm{i}}\right)\right]=\mathrm{K} \\
& \mathrm{E}\left(\boldsymbol{u}_{i} \boldsymbol{u}_{i}{ }^{\circ} \mid \boldsymbol{x}_{\mathrm{i}}, c_{i}\right)=\sigma^{2}{ }_{\mathrm{u}} \mathbf{I}_{\mathrm{T}}
\end{aligned}
$$

\footnotetext{
${ }^{32}$ Ver WOOLDRIDGE (2002, p. 268)
} 
A primeira delas é a hipótese usual de rank completo, e deixa explícito porquê $\boldsymbol{x}_{\mathrm{i} t}$ não pode conter elementos que não variam ao longo de t para nenhum i. A segunda hipótese (3.9) implica que os erros idiossincráticos têm variância cantante no tempo e não têm correlação serial $^{33}$.

A consideração central para se escolher entre a abordagem de Efeitos Fixos e Efeitos Aleatórios é se $c_{\mathrm{i}}$ é correlacionado com $x_{i}$. Efeitos Fixos geram estimativas consistentes se $c_{i}$ for correlacionado com $x_{i}$, enquanto neste caso efeitos Aleatórios geram estimativas inconsistentes. Portanto, uma diferença estatisticamente significativa entre as estimações de EF e EA é interpretada como evidência contra a hipótese de Efeitos Aleatórios (3.4b). O Teste de Hausman possibilita esta verificação ${ }^{34}$.

\footnotetext{
${ }^{33}$ É importante atentar para que os erros reportados na regressão de MQO a partir da equação (3.7) apresentarão correlação serial negativa, que tende à zero à medida que $\mathrm{T}$ aumenta, uma vez que dizem respeito à ü $\mathrm{u}_{\mathrm{i}} \mathrm{e} \mathrm{não}_{\mathrm{i}}$. Além disso, para se estimar a variância assintótica de $\beta_{\mathrm{EF}}$, é preciso realizar um ajuste no estimador da variância $\sigma_{\text {ü }}^{2}$ do erro transformado ü para que se obtenha o estimador apropriado para a variância $\sigma_{u}^{2}$ do o erro idiossincrático $u$ (ver WOOLDRIDGE, 2002, p. 271-272).

${ }^{34}$ Ver WOOLDRIDGE (2002, p. 288-291).
} 